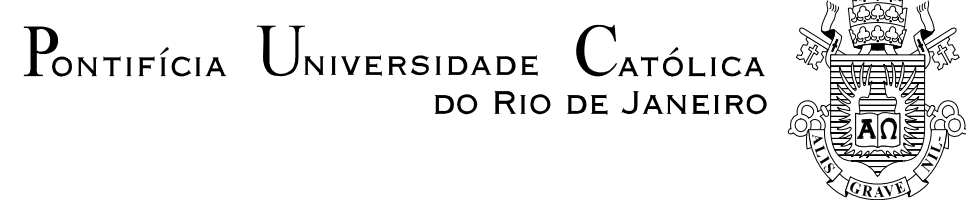

Daniela Pedreira Aragão

Voz e performance em Adriana Calcanhotto

Tese de Doutorado

Tese apresentada pelo Programa de Pós-Graduação em Literatura, Cultura e Contemporaneidade da PUC-Rio como requisito parcial para obtenção do título de Doutor em Letras.

Orientador: Prof. Júlio Cesar Valladão Diniz

Rio de Janeiro

Abril de 2013 


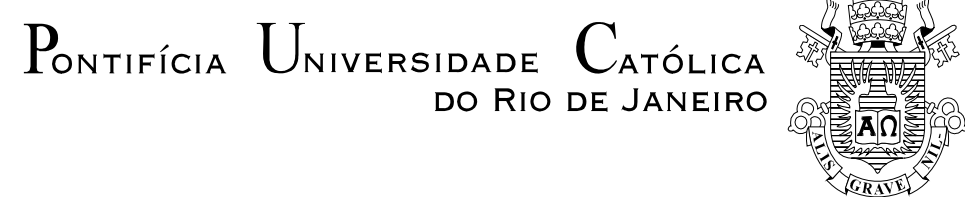

DANIELA PEDREIRA ARAGÃO

\title{
VOZ E PERFORMANCE EM ADRIANA CALCANHOTTO
}

Defesa de Tese apresentada como requisito parcial para obtenção do grau de Doutor pelo Programa de PósGraduação em Literatura, Cultura e Contemporaneidade do Departamento de Letras do Centro de Teologia e Ciências Humanas da PUC-Rio. Aprovada pela Comissão Examinadora abaixo assinada.

\author{
Prof. Júlio Cesar Valladão Diniz \\ Orientador \\ Departamento de Letras - PUC-Rio \\ Prof. Miguel Jost Ramos \\ Departamento de Letras - PUC-Rio \\ Prof. Frederico Augusto Liberalli de Goes \\ UFRJ \\ Prof. Alexandre Graça Faria \\ UFJF \\ Prof. Gilvan Procópio Ribeiro \\ UFJF \\ Profa. Denise Berruezo Portinari \\ Coordenadora Setorial do Centro de Teologia \\ e Ciências Humanas - PUC-Rio
}

Rio de Janeiro, 11 de abril de 2013. 
Todos os direitos reservados. É proibida a reprodução total ou parcial do trabalho sem autorização da autora, do orientador e da universidade.

\section{Daniela Pedreira Aragão}

Graduou-se em Letras pela Universidade Federal de Juiz de Fora, em 1999. Mestre em Literatura Brasileira pelo Programa de Pós-Graduação em Letras (Letras Vernáculas) da Universidade Federal do Rio de Janeiro, 2003. Ingressou em 2009 no Programa de Pós-Graduação em Letras da PUC-Rio.

Ficha Catalográfica

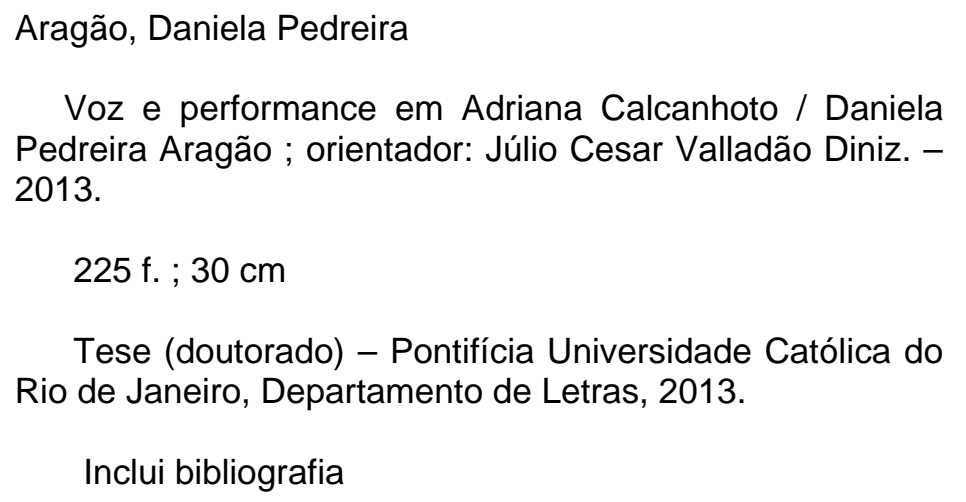

Voz e performance em Adriana Calcanhoto / Daniela Pedreira Aragão ; orientador: Júlio Cesar Valladão Diniz. 2013.

225 f. ; $30 \mathrm{~cm}$

Tese (doutorado) - Pontifícia Universidade Católica do Rio de Janeiro, Departamento de Letras, 2013.

Inclui bibliografia

1. Letras - Teses. 2. Música. 3. Performance. 4. Voz. 5. Poesia. 6. Adriana Calcanhoto. I. Diniz, Júlio Cesar Valladão. II. Pontifícia Universidade Católica do Rio de Janeiro. Departamento de Letras. III. Título.

CDD: 800 
Dedico esta tese à memória de meu pai, Jorge Aragão, que me ensinou a ver o mundo através da arte. A minha mãe, Zélia, pelo amor e acolhimento. A minha irmã, Marina, por me iluminar. 


\section{Agradecimentos}

Ao meu orientador Professor Júlio Diniz, pela confiança, inteligência e sensibilidade.

Ao amigo Jair Ferreira dos Santos, por me abrigar tantas vezes em sua casa e pelo afeto.

Ao meu irmão Fabinho, minha cunhada Montsserat e meus sobrinhos Tarumim e David, por me apoiarem.

Ao amigo e mestre musical Cristovão Bastos, pelo carinho e sensibilidade.

Ao amigo de "alma gêmea” Marcelo Robalinho, por nossas infindáveis conversas poéticas e musicais.

Ao amigo Acir Vidal, pelo afeto e vibração contínua.

À amiga Cassiana, pelo apoio constante e afeto.

À amiga Geysa Silva, pelo apoio e carinho de sempre.

À amiga Aparecida Meyer, mesmo na Itália não se esqueceu de mim.

Ao tio Bola, por compreender e me apoiar em todas as batalhas.

Aos amigos e companheiros de luta em Ouro Preto: Ana Terra, Maria da Conceição, Carlos Bracher e Dorothéia.

Aos colegas de trabalho do Cead-Cefet pelo apoio de sempre: Viviane, Marinalva, Sueli, Ângela, Thierse, Diego, Edilene e Valdirene.

Ao amigo Júlio, pela amizade de tantos anos e o apoio constante.

Aos meus alunos da Faculdade Fama (Mariana) e aos funcionários.

À Danielle, por todos os auxílios.

À Chiquinha pela delicadeza e atenção, sempre.

À coordenação do Programa de Pós-Graduação e aos colegas do curso, pela atenção constante.

Ao colega e professor Alexandre Faria, por suas tão úteis sacadas musicais.

À banca. 


\section{Resumo}

Aragão, Daniela Pedreira; Diniz, Júlio Cesar Valladão (Orientador). Voz e performance em Adriana Calcanhotto. Rio de Janeiro, 2013. 225p. Tese de Doutorado - Departamento de Letras, Pontifícia Universidade Católica do Rio de Janeiro.

O objetivo principal desta tese é analisar o desenvolvimento vocal da cantora Adriana Calcanhotto e o modo como ela imprime uma marca rasurante em suas interpretações. Este processo se efetua por meio de um intercâmbio com os cinco círculos semióticos estabelecidos por Júlio Diniz: a tradição sentimental e exagerada da música brasileira nos anos 40 e 50, o distúrbio geracional e sonoro das guitarras e cabelos compridos da Jovem Guarda, o minimalismo das ricas formas poéticas, harmônicas e melódicas da Bossa Nova e o engajamento barulhento e transformador das músicas de protesto. Pretende-se avaliar como se dá o desempenho performático da artista, a maneira como ela explicita o desenvolvimento de suas performances cênicas em seus shows, que revelam um forte diálogo com outras categorias artísticas, como a literatura e as artes plásticas. Seu percurso criativo demonstra uma busca acentuada por uma estética minimalista, que desponta tanto em sua expressividade vocal, quanto na manifestação corporal. Analisa-se, ainda, a criação do heterônimo-máscara Partimpim, o qual explicita o trabalho da artista voltado para o universo infantil, em que ela compõe canções e elabora releituras que demonstram a predominância de uma concepção lúdica expressa sobretudo nos arranjos.

\section{Palavras-chave}

Música; performance; voz; poesia; Adriana Calcanhotto. 


\section{Abstract}

Aragão, Daniela Pedreira; Diniz, Júlio Cesar Valladão (Advisor). Voice and performance in Adriana Calcanhotto. Rio de Janeiro, 2013. 225p. PhD Thesis - Departamento de Letras, Pontifícia Universidade Católica do Rio de Janeiro.

One of the objectives of this work is to analyse how process the acting voice of the singer Adriana Calcanhotto, and how does she makes a kind of signature between the influence of five semiotical circles created by Júlio Diniz: the exaggerated tradition of the sentimental feeling in brazilian songs from the ages of 40 and 50, the generation disturb of the sound of the electric guitar and long hair from Jovem Guarda, the minimalism of the rich forms of poetry, the harmony and melodic sound from Bossa Nova and the engaged noisy and the changes of songs of protest. Another propose is to consider how does she make her performances that shows a strong dialogue between other kinds of art as literature and plastical art. Her creative way that shows how does she work to find a minimalism and esthetic form. The way she express her expressivity of voice and body. The creation of her heteronym or mask Partimpim shows her work with the child universe, she compose songs and makes new versions that shows the ludic conception of the arrangements.

\section{Keywords}

Music; performance; voice; poetry; Adriana Calcanhotto. 


\section{Sumário}

1. Introdução 10

2. A voz e a rasura em Adriana Calcanhotto 14

3. A performance 74

3.1 A performance em Partimpim 1, 2 e 3

4. Encartes 171

5. Conclusão 214

$\begin{array}{ll}\text { 6. Bibliografia } & 216\end{array}$ 
O compositor me disse

Que eu cantasse distraidamente essa canção Que eu cantasse como se o vento Soprasse pela boca vindo do pulmão E que eu ficasse ao lado pra escutar o vento Jogando as palavras pelo ar O compositor me disse Que eu cantasse ligada no vento Sem ligar pras coisas que ele quis dizer Que eu não pensasse em mim nem em você Que eu cantasse distraidamente Como bate o coração $\mathrm{E}$ que eu parasse aqui Assim

Gilberto Gil 


\section{1}

\section{Introdução}

Esta tese foi idealizada a partir da minha leitura de alguns textos do professor Júlio Diniz, que me instigaram e despertaram o desejo de estudar ar relações entre música e literatura. A princípio sem possuir exatamente um objeto específico de análise, optei por assistir como ouvinte a um semestre de seu curso sobre a poética de Mário e Oswald, que me enriqueceu com muitas ideias e indagações, até que eu chegasse a optar definitivamente pela obra de Adriana Calcanhotto.

Através de conversas rápidas, que muitas vezes aconteciam após as aulas, Júlio Diniz ia me abrindo um leque de possibilidades musicais. Desde o princípio ele me apontou que o caminho poderia ser trilhado a partir de minhas predileções e afinidades. Sendo eu uma cantora, descobri então que a análise sobre o desempenho vocal de alguma cantora que me dissesse algo substancialmente poderia gerar um bom assunto de tese. Elaborei a princípio uma lista ampla e cronologicamente anárquica, com as intérpretes que mais me tocavam, como Dalva de Oliveira, Alaíde Costa, Leni Andrade, Nana Caymmi, Elis Regina, Joyce e Maria Bethânia. Depois fui dirigindo meu olhar e meus ouvidos para as cantoras mais próximas a minha geração, como Marisa Monte, Cássia Eller e Adriana Calcanhotto.

O desempenho vocal foi um dos critérios iniciais que impulsionou minha escolha por Adriana Calcanhotto. Com base na leitura do texto de Júlio Diniz intitulado "Sentimental demais: a voz como rasura”, percebi que a idéia da inscrição de uma assinatura rasurante no histórico de alguns cantores de nosso cancioneiro, defendida por ele, poderia ser devidamente analisada no percurso de Calcanhotto. Para dar prosseguimento aos estudos sobre a voz, recorri às análises realizadas por Paul Zumthor, além de artigos diversos publicados sobre o assunto nos livros "Palavra Cantada”, além de depoimentos do instrutor vocal da cantora, Felipe Abreu.

Dado o salto inicial, começamos a discutir sobre algumas ocorrências na obra de Calcanhotto, que a fazem se destacar em relação aos demais músicos 
contemporâneos. Percebemos que sua arte se ergue por meio de contínuos diálogos com outras categorias artísticas, como a literatura e as artes plásticas. Fizemos um percurso por toda a sua discografia, dirigindo nosso foco para as propostas dialógicas estabelecidas pela cantora, e pudemos constatar a forte presença das artes plásticas na elaboração dos encartes que foram analisados detalhadamente. Averiguamos também que seria relevante aprofundar nossa análise em relação à constância de diálogos estabelecidos por ela com o universo literário. Para tanto elaboramos uma triagem entre as canções que estabeleciam alguma relação com a literatura, poemas musicados, trechos de poemas citados, entre outras inserções poéticas foram minuciosamente selecionados por nós.

Como material de suporte recorremos a pesquisas em uma série de jornais, além de sites e imagens difundidas no youtube. O site da cantora forneceu-nos valiosas informações e textos críticos que nos auxiliaram na fundamentação de nossa pesquisa, principalmente para verificar o processo de amadurecimento da artista ao longo de mais de duas décadas de atividades ininterruptas.

Principalmente através da visualização das imagens dos shows de Calcanhotto difundidos em seus DVDS "Público", “Micróbio do samba” e "Partimpim", pudemos constatar o quanto é marcante na carreira dessa artista a questão performática. Decidimos dedicar um capítulo à análise do desempenho performático dessa artista ao longo de variados trabalhos. De "Enguiço" a "Micróbio do samba”, optamos pela elaboração de um percurso que demonstrasse a predominância da performance em suas atuações cênicas.

No decorrer de nossa pesquisa, notamos que seria importante adentrarmos também na produção de Calcanhotto dedicada ao universo infantil. Verificamos a inventividade da artista na criação de seu heterônimo-máscara Partimpim, uma invenção de destacável originalidade da artista, visto que, no histórico da música popular brasileira, nenhum outro artista antes havia praticado este procedimento, exceto Chico Buarque, momentaneamente, para burlar a censura no regime ditatorial.

No primeiro capítulo, "A voz e a rasura em Adriana Calcanhotto”, nos apoderamos então do conceito de "assinatura rasurante", formulado por Júlio Diniz, e percorremos analiticamente uma série de interpretações realizadas pela cantora. O evoluir de seu processo interpretativo, analisado essencialmente pelo desempenho de sua voz, é verificado minuciosamente numa dinâmica que envolve 
um campo rico e complexo de caracteres como timbre, texturas, afinação e extensão. Nas composições escolhidas por nós para análise, procuramos demonstrar com detalhes como se processam as inflexões da voz de Calcanhotto especificamente em cada canção. A passagem de uma entoação vocálica de caráter mais expressionista para uma dinâmica minimalista é verificada no decorrer de sua discografia: as composições interpretadas pela artista em seu álbum inaugural, "Enguiço”, se sobressaem por sua substância predominantemente expressionista e atípica em relação às suas demais interpretações. Verifica-se como a cantora articula sua revisão dos gêneros musicais, percorrendo os cinco círculos semióticos estabelecidos por Diniz: sua assinatura rasurante desponta na maneira como ela imprime versões dissonantes, que visam deixar em destaque, na maior parte dos casos, uma intenção provocativa e até iconoclasta. A questão da predominância de uma estética minimalista no canto cool de Calcanhotto é verificada por nós ao longo de sua discografia, a qual denota um percurso que valoriza cada vez mais a economia de recursos sonoros e a sobriedade interpretativa.

O segundo capítulo aborda a questão da performance, a maneira como se dá o desempenho corporal de Calcanhotto em suas atuações cênicas. O corpo em suas múltiplas dimensões expressivas constitui nosso alvo de destaque; avaliamos como, ao longo de suas apresentações, a artista demonstra uma ênfase considerável no aspecto performático. O termo performance é bastante utilizado na arte contemporânea para designar vários tipos de intervenções artísticas nas quais o artista assume o papel ativo frente ao público, atuando muitas vezes como o próprio veículo de expressão de sua obra. O objetivo da performance é transformar o corpo em um signo, em um veículo significante, cuja unidade de trabalho se apresenta numa variedade de sentidos (olfativo, táctil, auditivo). Desde seus primeiros espetáculos, nota-se como Adriana Calcanhotto confere importância significativa à desenvoltura do corpo no espaço cênico. Figurinos e cenários denotam como é relevante a presença das artes plásticas nos seus trabalhos. Dialogando com a produção de artistas como Hélio Oiticica, Mondrian e Andy Wahrol, ela expõe o universo da contemporaneidade como cenário de suas performances.

Ainda dentro deste capítulo estendemos nossas reflexões para a questão da performance evidenciada nos álbuns da série Partimpim. O diálogo com as 
estéticas de vanguarda, verificado em suas relações dialógicas com outras categorias artísticas, como a literatura e as artes plásticas, mantém-se em Partimpim na maneira como ela abusa de experimentalismos sonoros, valorizando o caráter inventivo e investigativo nas crianças. Para fundamentar nossa análise, recorremos às reflexões da educadora Fayga Ostrower, que nos auxiliou consideravelmente no traçado do panorama do universo infantil. Para enriquecer nossa pesquisa, fizemos um breve percurso por outros trabalhos musicais também direcionados ao mundo da criança, como “A arca de Noé”, de Vinícius de Moraes. Um dos pontos cruciais desta seção se concentra em nosso objetivo de mostrar o quanto o trabalho desenvolvido em Partimpim dirige-se ao público infantil, mas sem aplicar uma linguagem redutora.

O capítulo final de nossa tese concentra-se na abordagem estética dos encartes dos CDs de Calcanhotto, que valorizam a qualidade do tratamento visual. Procuramos mostrar, sob a análise minuciosa de cada encarte, como o trabalho gráfico compõe um sentido relevante em relação à totalidade da obra da artista. Para tanto, alicerçamo-nos de uma pesquisa visual que abrangeu um percurso analítico pela história da composição do design gráfico das capas de disco no Brasil. Retrocedemos ao tempo das criações das capas do selo "Elenco", sucedido pela inventividade do artista Elifas Andreato. Verificamos como o design dos encartes de Calcanhotto demonstra uma perspectiva que dialoga com o conteúdo das músicas. Flertando com o cinema, a literatura e, sobretudo, as artes plásticas, esta artista incorpora, contrapõe e superpõe conceitos. As artes plásticas figuram em destaque nas capas que fazem inferência a diversos artistas e obras.

Sendo assim, procuramos em nossa tese abordar a criação da artista Adriana Calcanhotto por meio da tríade que consideramos essencial: voz, performance e encarte. 


\section{Calcanhotto: a voz que rasura}

Júlio Diniz em “Sentimental demais: a voz como rasura” (2003) estabelece um percurso analítico que traz para o centro da discussão a problemática da voz como rasura. O pesquisador inicia seu texto com a citação de "Que será", composição de Marino Pinto e Mário Rossi, que obteve muito sucesso na voz de Dalva de Oliveira. A escolha desta canção nada tem de aleatório, pois Diniz aponta Dalva como um ícone da era das grandes vozes no Brasil; uma cantora que traz como marca a expressividade do canto, em que o excesso sentimental se sobrepõe à contenção. Diniz se propõe a interpretar este fenômeno em forma de provocação, problematizando quais seriam os mecanismos utilizados para compreender a tradição/tradução interpretativa deste excesso na MPB, característica comum na sua história. Ao analisar o percurso das vozes no Brasil, o pesquisador argumenta que existe a formação de uma significativa construção identitária que se explicita através do que ele denomina de "voz como assinatura rasurada”,

[...] de outras vozes rasuradas, uma genealogia do canto no Brasil. Para isso eu utilizo uma idéia que é a de pensar a canção através da corporificação que a voz outorga ao conjunto enunciação/enunciado, ao escriturante como letra e ao musicante como som. (DINIZ, 2003, p.99)

Essa voz que imprime sua assinatura, sua rasura, sua marca, é, na verdade, uma nova voz resultante de outras vozes rasuradas, pois é através do desempenho da voz que o cantor imprime seu registro, impõe seu traço singular e diferencial. Dessa maneira, é imprescindível mencionar o fato de que a emissão vocal, qualquer que seja ela, coloca em vibração todo o corpo, não envolve apenas o tórax e o crânio. A voz do cantor transcende a qualidade do som que sai pela boca, pois o ato de cantar abarca todo o corpo, uma vez que o ato de cantar

[...] é o próprio movimento de expressão, aquilo que projeta as significações no exterior dando-lhes um lugar, aquilo que faz com que elas comecem a existir como coisas sob nossas mãos, sob nossos olhos. (MERLEAU PONTY, 1996, p.202) 
Desse modo, é somente através do movimento da expressão vocal e da emissão da voz, como um todo, que a canção ganha real existência e uma música adquire diferentes significações conforme a interpretação de cada artista. Enquanto o cantor não imprime a sua voz e o seu corpo na canção, a letra se limita a um conjunto de palavras inertes, pois a letra no corpo do papel é diferente da letra no corpo da música, estrutura e função se rearticulam num contexto comunicativo alterado (DINIZ, 2003). O intérprete, por meio de sua intuição e sensibilidade, é capaz de dar uma leitura muito particular a uma canção, valorizando nuances poéticas e sutilezas sonoras. Deve-se considerar, contudo, que o corpo do artista está inserido, como discurso, no corpo da cultura:

[...] com todo o seu aparato simbólico e, pensando em alguns aspectos da cultura brasileira, em seu sentido alegórico. É a voz que para mim funciona nessa passagem da Bossa Nova para o Tropicalismo, do intimismo ao excesso, da introspecção à espetacularização, do banquinho e violão ao concerto barroco das justaposições, daquilo que eu poderia chamar de "a rasura da voz" ou "a voz como uma assinatura rasurante”. (DINIZ, 2003, p.100)

O que Diniz problematiza é a existência, na MPB, de uma tradição do canto como tradução que se inicia com a Bossa Nova e se expande com força no Tropicalismo, a partir da tensão entre os “cinco círculos semióticos intercomunicantes”, quais sejam,

[...] a tradição sentimental e exagerada da música brasileira dos anos 40 e 50; o distúrbio geracional e sonoro das guitarras e cabelos compridos da Jovem Guarda; o minimalismo das ricas formas poéticas, harmônicas e melódicas da Bossa Nova; o engajamento barulhento e transformador da canção de protesto, com sua vocação redentora e revolucionária; e a alegoria carnavalizante dos corpos, cores e códices do tropicalismo. (DINIZ, 2003, p.109)

A tensão entre os cinco círculos semióticos intercomunicantes articula um constante trabalho de diálogo com a tradição, cujo processo desenvolve a criação, veiculação e recepção do cancioneiro popular. Diniz reflete sobre o percurso da música popular brasileira marcado por uma série de transformações no decorrer de sua evolução e que resultam na consequente modificação no desempenho dos cantores. Um cantor não limita sua voz apenas ao âmbito das habilidades técnicas. Ele demonstra sua força criadora sobretudo pela consciência que possui do trabalho que desenvolve em relação ao debate artístico e estético que envolve o universo da música e das artes. Calcanhotto é uma artista que demonstra a consistência do diálogo que elabora com as estéticas musicais abordadas por 
Diniz. Em sua trajetória musical ela evidencia a contínua incorporação dos círculos semióticos problematizados pelo pesquisador e mostra que, por meio de apropriações e desapropriações, suas leituras-releituras-desleituras musicais são resultado do intercâmbio dialógico traçado com estéticas musicais que se singularizam por suas características e propostas, de certa maneira até iconoclastas, como preconiza o Tropicalismo. Há que se notar a maneira como Calcanhotto procede em suas incorporações, ela se apropria do ideário da tradição sentimental dos anos 40 e 50, porém não aprofunda uma exacerbação amorosa típica do estilo. A cantora elabora versos que retomam a atmosfera ultra romântica das canções sentimentais, todavia retira o exagero interpretativo e introduz sua própria versão, em que a leveza contrasta com o legado carregado de excessos, como exemplifica a canção "Mentiras". A Jovem Guarda é revisitada por Calcanhotto, que alivia seu distúrbio sonoro recriando as antigas canções por meio de seu jeito suave de interpretar: o Kitsch e o excesso de uma estética voltada para uma expressão artística destituída de compromissos ideológicos transformam-se em elegância expressiva. O legado da canção de protesto aparece em músicas que explicitam um caráter iconoclasta, a exemplo de "Senhas”, em que a cantora deixa às claras sua postura inconformada, sem no entanto alimentar nenhuma aspiração messiânica. Calcanhotto questiona atitudes e comportamentos e revela a insustentabilidade da manutenção dos mitos de poder, utilizando-se frequentemente de metáforas que tornam as músicas um território de indagações. A carnavalização tropicalista aparece em músicas que acentuam um caráter irônico e alegórico, como revela "Vamos comer Caetano", em que a artista rearticula certos pressupostos estéticos pertencentes ao movimento. Quanto ao círculo semiótico relativo à Bossa Nova, nota-se que Calcanhotto é uma artista que traz em suas performances características comuns à estética bossanovista que se evidenciam na expressividade do canto e no formato das músicas.

No cd "O micróbio do samba”, Calcanhotto explicita a sua assinatura de feição mais rasurante dentre todos os demais trabalhos, porquanto é um disco que aparentemente se propõe a ser uma reunião exclusiva de sambas, mas que, em sua fatura, transcende as características do gênero, revelando uma espécie de ruptura/ dissonância com o modelo tradicional dos álbuns de samba, a exemplo de Tereza Cristina, Dona Ivone Lara e Martinho da Vila. O título da obra é extraído de uma fala do compositor Lupicínio Rodrigues, o que, de antemão, já sinaliza o diálogo 
que a cantora estabelece com a tradição. O encarte do cd traz em destaque a reflexão do compositor que dá suporte à proposta estético-musical desenvolvida por Calcanhotto:

Veja que desde pequeno trazia no sangue o micróbio do samba, esse micróbio que cresceu comigo e não quer me abandonar, quanto mais velho eu fico mais ele se apega a mim (In: CALCANHOTTO, 2011).

Lupicínio Rodrigues, ao longo de sua carreira, compôs marchinhas de carnaval e sobretudo sambas-canção. Suas músicas, que tematizavam sofrimentos amorosos e sugeriam um clima de "fossa," foram as que levaram a fixar seu nome na história da música popular brasileira. Seus versos permeados de lamúrias e dores ocasionadas por desilusões amorosas serviram de inspiração para vários compositores e intérpretes. A frase de Lupicínio na qual Calcanhotto se inspira para nomear sua obra, deixa em evidência a sua filiação ao gênero samba. Ela estabelece uma irmandade musical com Lupicínio na medida em que também reconhece em si um forte substrato musical que advém do samba:

[...] se você descascar os arranjos, a superfície mesmo é samba, tem samba, ou contém samba ou vem do samba, entende? A maneira com que eu ouço o mundo é samba, qualquer ruído que eu ouço, máquina de café, em sequência máquina de lavar, um barulho de vagão de trem, qualquer coisa repetitiva o meu ouvido entende como samba, pra mim são células de samba. (http://www.youtube.com/watch?v=WX9Nv-I57PM)

Tratando-se de Calcanhotto, sua apropriação da fala de Lupicínio é emblemática na proporção em que sugere não somente a sua compatibilidade com o gênero samba, mas também insinua um diálogo com o universo musical do compositor, que tem sua completude nas canções amorosas. Constata-se por conseguinte que não é por mero acaso que a artista traz à tona a reflexão de Lupicínio impressa no encarte do CD "Micróbio do samba"; por meio das sugestões implícitas na obra do compositor a artista abre para o ouvinte um caminho de leitura para o álbum.

Numa primeira audição o disco chama a atenção por sua sonoridade aparentemente monocórdica, já que são doze canções que parecem às vezes uma única, que segue seu percurso com aclives e declives sonoros do começo ao fim. Durante as demais audições a sensação de unicidade que permeia o trabalho persiste, concluindo-se daí que a artista quer provocar o ouvinte por meio do 
caráter meio "estranho" ao gênero samba que ele impõe. Na elaboração dos arranjos, no ritmo e no canto, Calcanhotto mostra pontos de dissonância com o modelo tradicional do samba, pois, através da introdução de guitarras, piano (executado pela própria), pratos, violões, cuícas e cavaquinhos, a artista prima por um conjunto de músicas que se sobressaem por uma profusão de misturas, que se dá por meio de uma leitura rasurante plena de contrastes, fundindo o legado da tradição dos grandes sambistas (Lupicínio Rodrigues, Cartola, Nelson Cavaquinho) a um experimentalismo de vertente contemporânea. Calcanhotto incursiona por uma tradição centrada essencialmente no discurso masculino, na qual os temas clássicos do samba estão presentes, como o malandro, a boemia, a orgia e a relação conjugal. Entretanto estes temas são retomados e reelaborados sob o olhar contemporâneo da artista, que subverte o viés machista que prevaleceu durante décadas no samba. A mulher que figurava no imaginário dos sambistas muda de postura em "Micróbio do samba", como quer a canção "Mais perfumado":

\footnotetext{
Quando reclama do meu vestido Quando se zanga porque trabalho Quando se mostra muito amoroso Quando aparece não atrasado Sai para o jogo com o ar distraído E volta pra casa mais perfumado Ele acredita que me engano
} Pensa que sabe mentir, o homem que eu amo (In: CALCANHOTTO, 2011)

Os versos de "Mais perfumado" possibilitam uma conexão com o antigo sucesso "Solteiro é melhor", que estourou no carnaval de 1940 na voz de Francisco Alves. Esta música, interpretada a cerca de sete décadas, mostra a figura masculina que subestima a capacidade da mulher, taxando-a de ingênua. Em "Mais perfumado" a cantora inverte a perspectiva machista e expõe a mulher que assume as rédeas do discurso.

Eu consigo ludibriar toda a gente

Eu afirmo e até garanto

Neste assunto sou primeiro

Sou casado e no entanto

Oi! Levo a vida de solteiro (http://www.youtube.com/watch?v=D0iDs1D5rmk)

Calcanhotto atribui às mulheres de suas composições poder, autonomia e ação, enquanto os homens surgem submissos à figura feminina e carentes de 
atenção. Ao inverter as posições dos gêneros, a compositora mexe com o ideário da tradição do samba. Sob a expressão irônica de Calcanhotto em "Vem ver”, o homem suplica o amor da mulher, colocando-se numa posição de obediência:

Por você largava tudo, arranjava o que fazer

Até voltaria cedo, eu deixava de beber

Vem cá, vem ver, vem ver

[...] por você tomava rumo, arrumava o que fazer

Eu levantaria cedo, eu cuidava do bebê

Vem cá, vem ver, vem ver (In: CALCANHOTTO, 2011)

Além do caráter acentuadamente crítico que perfaz os diálogos que

Calcanhotto elabora com a tradição do samba, ela também reverencia puramente a tradição da riqueza construtiva expressa na música e letra de Cartola. "Eu vivo a sorrir” alude a "O sol nascerá”, de Cartola :

Eu vivo a sorrir, eu vivo a sorrir

Pro acaso de você virar a esquina

E adentrar a livraria

Pro caso de o acaso estar num bom dia

Pro caso de o destino me haver reservado a alegria

E o meu fado estar fadado a ser a sua sina

Eu vivo a sorrir, eu vivo a sorrir

Pro caso de você errar a vereda

E acertar o elevador

Pro caso de o acaso estar inspirado

E emaranhar, por capricho, tempo e espaço

Cruzando as nossas linhas soltas num laço (In: CALCANHOTTO, 2011)

A sorrir eu pretendo levar a vida

Pois chorando eu vi a mocidade perdida

Fim da tempestade o sol nascerá

Fim dessa saudade, hei de ter outro alguém para amar

(http://www.youtube.com/watch?v=V4XyIl1IPN0)

Calcanhotto homenageia Cartola no primeiro verso de cada estrofe de "Eu vivo a sorrir”, enquanto a música, conduzida pela bateria de Domênico, baixo acústico de Alberto Continentino e violão de Davi Moraes, elabora uma concepção sonora com predominância rítmica, mas que não constitui propriamente um samba. O estilo do samba tradicional de Cartola em "O sol nascerá” é suplantado, em "Eu vivo a sorrir", por um arranjo que desmancha sua sonoridade compactada, feita de acordes maiores e menores. A música de Calcanhotto faz uso de acordes dissonantes, cuja harmonia é mais elaborada e revela nuances que marcam uma sofisticação sonora, tendo em vista o formato 
mais quadrado do samba tradicional. Muniz Sodré, ao tematizar a questão do samba e seu percurso histórico em “O dono do corpo” (1998), enfatiza no gênero a presença da síncopa, que consiste na "batida que falta", ou seja, aquela que caracteriza-se pela ausência no compasso de um tempo fraco que, no entanto, repercute noutro mais forte. No samba a síncopa exerce uma atuação fundamental, incitando o ouvinte a preencher o tempo vazio com a marcação corporal, feita de palmas, meneios, balanços e dança. O corpo também faz falta na síncopa e, consequentemente, a força magnética deste ritmo contagiante advém, conforme Sodré, do impulso de se preencher a lacuna temporal com a dinâmica do movimento no espaço.

Quando pensamos no desempenho do corpo associado ao samba, devemos dirigir nossa reflexão para a importância exercida pela influência africana. O ritmo do samba conduz a uma dança que subjuga o corpo, que se movimenta em sua riqueza expressiva. Os africanos trouxeram para o Brasil formas celebratórias originais como o batuque, modalidade rítmico-sonora que se caracteriza pelo uso da percussão, dança e canto embutidos num mesmo rito. Nas palavras de Rugendas

A dança habitual dos negros é o batuque. Desde que haja alguns reunidos, ouvem-se cadenciadas palmas: é o sinal com que se chama e provoca, por assim dizer para a dança. O batuque é conduzido por um figurante. Consiste em certos movimentos do corpo, que são, talvez, bem expressivos; principalmente os quadris é que se movem. Enquanto o dançarino estala a língua e os dedos e se acompanha com um canto bastante monótono, os outros formam o círculo em torno dele e repetem o estribilho. (RUGENDAS, 1987, p.194)

O samba, nos seus primórdios, possuía um conjunto de gestos e passos criados pelos mestres do gênero, que organizavam os desfiles e brilhavam nas tradicionais festas familiares. Nestas festas, várias modalidades de dança-cantobatuque afro-brasileiras eram praticadas e difundidas aos membros mais jovens das comunidades. A ginga no samba traz a impressão de que o dançarino está andando, embora apenas alterne o peso do corpo de um pé para outro, sem sair muito do lugar. As transições explicitadas nos movimentos dos pés são suaves e obedecem a uma sensual cadência do samba. Os braços, levemente dobrados, guardam uma linha acima do quadril, elaboram uma espécie de zigue-zague de um lado para outro. 
Conforme analisa Hermano Vianna em “O mistério do samba” (1995), somente nos anos 30 o samba carioca começou a colonizar o carnaval brasileiro, transformando-se em símbolo de nacionalidade, enquanto os demais gêneros produzidos no Brasil passaram a ser considerados regionais. A Casa da Tia Ciata, espaço “matricial”, lugar de gestação do samba, situava-se na Praça Onze. Nela surgiu "Pelo telefone”, o samba que lançaria no mercado fonográfico um novo gênero musical. Os músicos responsáveis por esta gravação foram recrutados entre os frequentadores da casa, uma espécie de centro de continuidade da Bahia negra composto por nomes como Pixinguinha, Sinhô, Donga e Heitor da Bahiana. A partir daí o samba começou a ganhar as ruas, fazendo da Praça Onze uma “África em miniatura”, como diz Heitor dos Prazeres.

Em "Eu vivo a sorrir", a presença do contrabaixo acústico tocado por Alberto Continentino imprime uma quebra na estrutura formal do samba. Nesta canção, o desempenho sonoro do contrabaixo é tão significativo que chega a ocupar um possível lugar do bumbo, por exemplo, instrumento usual no samba. Toda a estranheza que provoca no ouvinte a inserção de instrumentos e sonoridades atípicas ao samba é resultante de uma estratégia intencional de Calcanhotto, pois os sambas compostos por ela ultrapassam o enquadramento nas delimitações impostas ao gênero. A cantora relê o samba conforme sua estética, os pontos em que a dissonância fala mais alto são justamente aqueles em que a artista contrapõe seu talento individual à tradição.

Parecido com outros trabalhos que eu fiz, ele tem uma conversa com o imaginário, os sambas antigos, com as coisas que me formaram, eu enxergo totalmente as influências, onde é que está o Lupicínio, o Ismael, as conversinhas, as coisas, essa coisa que o Lupicínio fala do Micróbio do samba, quer dizer, você tem o micróbio e não necessariamente você é uma pessoa do mundo do samba, você pretende ser sambista, eu não tenho a menor pretensão. (http://www.youtube.com/watch?v=wrkcw6SmV38\&playnext=1\&list=PLA790D 173EBB42434\&feature=results_main)

Ao analisarmos a performance vocal de Calcanhotto em "Eu vivo a sorrir" e nas demais composições do álbum, torna-se imprescindível passarmos por alguns pontos que tocam a natureza de qualquer cantor. É pelo mecanismo de funcionamento das pregas vocais em seus vários movimentos de alongamento, encurtamento, adução e abdução, tensão e relaxamento que se define o grau de tensividade da voz. Outro fator determinante na emissão do som é a produção do 
ar que se forma na região subglótica, partindo-se da afirmativa de que esta empurra as pregas vocais, fazendo-as produzir um som ondulatório. O domínio da respiração consiste numa das principais prerrogativas para o bom desempenho do cantor; durante o canto, a expiração, que se dá normalmente num processo passivo torna-se uma ação ativa e adquire uma duração maior do que a inspiração. Conforme as solicitações da música, a expiração assume diferentes dinâmicas: ela pode ser retida, suspensa, acelerada, retardada, provocar aumento ou diminuição do ar que sai. Com relação à posição expiratória no canto, três áreas musculares estão diretamente envolvidas durante a produção da expiração e do apoio, quais sejam: músculos intercostais, músculos abdominais e diafragma. Cada tom que o cantor emite, dependendo da altura e intensidade, demanda uma certa energia que se obtém por meio do controle da quantidade de ar. O cantor que domina seus recursos vocais sabe usar e dosar a musculatura que controla a sua respiração e consequentemente não sobrecarrega as cordas vocais. O uso inadequado da voz costuma aparecer quando o cantor faz um esforço exagerado para aumentar o volume da voz, procedimento altamente danoso para a saúde vocal. Mesmo a prática de estudo da voz deve vir com prudência e comedimento, pois, nas palavras de José de Oliveira Lopes,

A um principiante não deve ser solicitado fazer exercícios de canto com grande intensidade, pois pode conduzir a vícios de difícil correção futura, como sejam: voz impura, soprada, gritada, branca, desigual, etc. Deve-se procurar cantar tão natural e livremente como se fala [...] A voz deve ser simultaneamente estável e flexível, a colocação dos agudos deve ser feita como se os cantasse em piano. Quer a excessiva força quer a frouxidão da voz são prejudiciais para a laringe. (LOPES, 2011, p.75)

Devido à sofisticação do canto popular e à proliferação de uma diversidade de tecnologias que o cantor deve aprender a dominar, a figura do preparador vocal tem se tornado cada vez mais frequente no universo dos artistas. O preparador vocal é capaz de otimizar a vida do cantor na medida em que o auxilia, dando-lhe suporte para o uso adequado da voz. Com a ajuda do preparador, o cantor executa exercícios e vocalizes e se torna mais aparelhado para analisar e explorar novas canções, sabendo fazer bom uso da dicção, articulação, pronúncia, afinação, ritmo e melodia. Com uma articulação bem estruturada o cantor é capaz de comunicarse melhor com a base instrumental e consequentemente realizar uma interpretação de mais qualidade. O preparador vocal pode auxiliar também o cantor na escolha 
da tonalidade das canções, elegendo o tom apropriado ao registro e tessitura vocal, fazendo com que o cantor cante com conforto, sem fazer nenhum esforço que ocasione qualquer tipo de lesão nas cordas vocais. Com relação à escolha da tonalidade da canção, o mais importante não é o cantor conseguir alcançar determinadas notas agudas ou graves, mas sim ser capaz de, por meio de uma tonalidade adequada, ressaltar o colorido da canção. Toda música possui uma cor e o cantor, quando encontra o seu ponto certo na interpretação, faz com que desponte o colorido da canção, que se constrói através do brilho do timbre, da clareza na emissão das notas e da respiração correta. O colorido e a intensidade da voz são muito importantes, por isso o cantor deve aprender a controlá-los. Segundo o estudioso de voz

O exercício indicado para adquirir essa técnica é conhecido pela expressão messare lavoce, de que se indica como exemplo tentar desenvolver a mesma nota começando em piano até mezzo forte, decrescendo de novo para piano, numa só respiração. (LOPES, 2011, p.76)

Lopes argumenta que, além das funções sensitivas e motoras que permeiam o universo dos cantores, sobressai a memória, que consiste numa das atividades fundamentais. É por meio da memória que o cantor é capaz de dirigir toda a sua atenção para a emissão vocal, sem estar atrelado aos condicionamentos da partitura ou textos. A memória do cantor atua no sentido de que, ao longo dos vários anos de prática e aprendizagem ele é capaz de automatizar os conhecimentos adquiridos, cantando com liberdade.

A relação entre o cantor e o preparador vocal deve ser envolvida por uma atmosfera de mútua confiança, em que não haja, principalmente por parte do instrutor, nenhuma tentativa de adulterar as características que definem a existência única da voz a qual lhe cabe o ofício de trabalhar. O preparador vocal Felipe Abreu define:

Quando inicio o trabalho com um cantor, ele me traz sua voz, seu corpo, sua experiência musical, sua sensibilidade individual, sua inteligência e o material (voz e repertório) com que vamos trabalhar. Se fizermos uma analogia com a escolha de um guarda-roupa, é como se a pessoa me trouxesse seu corpo, individual e único (que pode ou não ter sido previamente trabalhado, que pode estar "malhado" ou "largadão") e as roupas que ele quer vestir (as canções que quer cantar), os tecidos e as cores que ele quer usar (as texturas, a dinâmica, os timbres). A partir daí, passamos à discussão: os cortes combinam com seu corpo? As cores combinam entre si? Está colorido demais ou de menos? Os acessórios combinam, estão excessivos? Como achar unidades e contrastes neste guarda- 
roupa sem que fique monocromático ou sem um estilo marcante? Como fazer esse figurino parecer criado especialmente para você? (In: MATOS; MEDEIROS; TRAVASSOS, 2008, p.127)

Embora a técnica vocal aplicada à música popular utilize alguns recursos do canto lírico, como os vocalizes, seu objetivo é distinto pois não visa à empostação do canto. O bom preparador vocal conjuga a intuição e espontaneidade existentes na essência do cantor e o auxilia no processo de afirmação de sua identidade musical. É importante que o cantor seja capaz de valorizar seu próprio estilo e saiba tirar proveito das qualidades que o fazem único, que firmam sua marca. O valor de um artista na contemporaneidade se dá sobretudo por sua originalidade, sua assinatura inigualável. Sendo assim, imitadores, covers e clones não ultrapassam a posição de subprodutos, jamais chegam a um verdadeiro lugar de reconhecimento. José de Oliveira Lopes explicita também seu olhar sobre o desempenho do técnico vocal:

O professor de canto terá que municiar os alunos com os diversos caminhos que os levarão a assumir uma técnica que, embora contendo princípios gerais e comuns a todos, pode no entanto, e na sua especificidade, ser intuída de forma diferente por cada aluno. Esse "desdobrar" da parte do docente - tentando explicitar de uma ou várias formas até que o aluno apreenda uma técnica que lhe servirá a si, individualmente, podendo não ser a indicada para outro colega - é o maior desafio que se coloca a um pedagogo. (LOPES, 2007, p.57)

Felipe Abreu e José de Oliveira Lopes enfatizam a importância do desempenho de um técnico vocal, que deve ser um indivíduo consciente do seu papel de incentivar o cantor/aluno a buscar seus próprios caminhos musicais. A identidade do cantor não se constrói unicamente pelo fato de ele pronunciar as notas com exatidão; muitas vezes uma aparente falha, que poderia soar como ponto negativo para o cantor, torna-se sua marca registrada. A cantora Alaíde Costa fez carreira nacional e internacional com a beleza do seu timbre e uma dicção imprecisa em que a língua presa dá um toque singular ao seu estilo.

Calcanhotto é uma cantora que, no decorrer da carreira, mostra um percurso composto por modificações. Em seu disco de estréia, “Enguiço” seu canto dá primazia a expansividade, em que sua voz projeta-se com uma dinâmica que incorpora muitos movimentos de ascendência e descendência. Neste CD ela deixa evidente certo caráter performático em seu canto, elabora modulações em sua voz que explicitam sua versatilidade interpretativa. Os tons das músicas, em 
sua maioria, favorecem a emissão de notas mais agudas, como se verifica em "Pão doce”, "Nunca” e "Caminhoneiro”. Mesmo que a cantora demonstre experiência para interpretar canções com arranjos virtuosos, observa-se que esses arranjos soam às vezes excessivos para a textura de sua voz. Se o objetivo deste disco de estréia é mostrar ao público a voz da cantora, ele não consegue cumprir integralmente a proposta, pois o formato "monumental" dos arranjos suplanta a dinâmica da voz de Calcanhotto.

Na música "Enguiço", o peso da base composta por um arranjo de metais acrescido de bateria, guitarra e contrabaixo quase anula a voz pequena da cantora, que parece vir atrás dos instrumentos. Em "Senhas", seu segundo CD, os arranjos suntuosos permanecem, mas Calcanhotto adequa melhor seu canto, possivelmente devido ao fato de que a maior parte das canções são de sua autoria. Nota-se a presença de certos traços que irão desaparecendo ao longo de seus sucessivos CDS, como ocorre com a pronúncia acentuada do " $r$ " retroflexo que marca sua origem gaúcha. Em músicas como "Esquadros” e “Tons”, a pronúncia deste "r” é bastante evidente: "eu presto muita atenção no que o meu î irmão ouve/pela janela do quarto”, “calipsos, cortesias, cores” (grifo nosso). O álbum "Senhas”, em sua totalidade, traz Calcanhotto ainda bem vinculada às raízes gaúchas no que diz respeito à questão do canto, mas sua interpretação perde um pouco da feição hiperbólica que pontuou seu disco de estreia. A cantora já começa a prenunciar sutis mudanças, que se constatam pela projeção da voz em tonalidades menos agudas e por interpretações mais intimistas, como se verifica em sua leitura minimalista da canção “O nome da cidade”. Somente acompanhada por seu violão e com leves efeitos sonoros ao fundo, Calcanhotto interpreta a música de Caetano Veloso de maneira intimista, em que sua voz ecoa suavemente em harmonia com a melodia. Cumpre destacar que Caetano Veloso compôs "O nome da cidade" inspirado na personagem Macabéa, do livro “A hora da estrela”, de Clarice Lispector. Esta é apenas uma das canções que explicita o diálogo que a cantora estabelece com o mundo literário. A partir do cd “A fábrica do poema”, essa relação se torna declarada e a artista aponta a relação intrínseca que estabelece com o universo poético.

Na antiguidade, a voz funcionou musicalmente na transmissão de todo o discurso poético quando ele era realizado por via oral, destituído do signo da letra. A poesia antiga e a medieval eram essencialmente cantadas ou entoadas, tinham a 
proeminência da palavra cantada. Como infere o título do álbum, a artista abre sua oficina de poemas, a palavra falada também pode ser transformada, sob seu engenho, em palavra cantada.

Lembro-me de que quando comecei a minha carreira de música, pra mim não era pra ser uma carreira de música, na verdade era uma coisa bem mais ligada à palavra [...] Gosto de cantar as músicas que não são minhas como se fossem minhas, eu me relaciono assim com os poemas. Para difundir poesia [...] tem que fazer sentido pra mim, de alguma maneira, senão acho que fica gratuito. (In: MATOS; MEDEIROS; TRAVASSOS: 2008, p. 45-47)

Na contracapa do encarte tem-se a foto de vários livros empilhados com os títulos das 15 músicas do CD escritos em suas calhas, o que remete a criação musical de Calcanhotto à linguagem da literatura. Ao ler um texto, a artista enxerga várias possibilidades musicais, e procura realizar uma primeira música que encontra no texto. Ela expõe dessa forma a sua escolha da possibilidade de criação:

Sinto que há outras, mas depois a música fica mais ou menos estabelecida pra mim, fica muito difícil mudar, aquilo fica meio que norteando o resto do trabalho. Tanto em poemas com a métrica ajustada quanto nos mais livres - os do Waly (Salomão), por exemplo, são totalmente livres e são enormes - eu nunca mudei nada não, eu acho mais engraçado trabalhar no poema como ele é. (In: MATOS; MEDEIROS; TRAVASSOS: 2008, p.44)

Calcanhotto dá mais importância ao ritmo do texto que está lendo, pois, segundo ela, o ritmo da frase falada é o acento que constrói a melodia. A palavra ritmo vem do grego rhytmos, cuja designação é tudo aquilo que flui num movimento regulado. O ritmo musical é um acontecimento sonoro, tenha ele altura definida ou não, que ocorre numa certa regularidade temporal. Dessa forma, a artista procura detectar nos textos que lê uma ordenação de sons de acordo com padrões musicais estabelecidos, e a variação da duração e acentuação de uma série de sons ou eventos que possam ser musicados. "Por que você faz cinema?”, canção que abre o $\mathrm{CD}$, surgiu a partir do momento em que Calcanhotto se deparou com um catálogo da mostra "Joaquim Pedro de Andrade" no qual havia a entrevista concedida pelo cineasta para o jornal francês "Libération". Segundo a cantora, a cadência rítmica sugerida pela fala de Joaquim Pedro já lhe trazia um encadeamento melódico que favoreceu a criação da música. Nesta canção/fala ela explicita uma espécie de manifesto que dará a tônica de todo o trabalho, configurado a partir de uma ruptura com a tradição, marca da modernidade. 
De acordo com Octávio Paz em “Os filhos do barro” (1984), a modernidade se caracteriza por uma espécie de autodestruição criadora, cuja produção artística é marcada pela autocrítica que incessantemente elabora e reelabora o processo de construção e dissolução. Dessa forma, o artista, na modernidade, retoma o passado incorporando-o e, simultaneamente, destruindo-o, pois, como argumenta o crítico

A modernidade é sinônimo de crítica e se identifica com a mudança: não é a afirmação de um princípio intemporal, mas o desdobrar da razão crítica que, sem cessar, se interroga, se examina e se destrói para renascer novamente. Não somos regidos pelo princípio da identidade nem por suas enormes e monótonas tautologias, mas pela alteridade e a contradição, a crítica em suas vertiginosas manifestações. (PAZ, 1984, p.47)

Ou seja, se no passado o objetivo da crítica era atingir a verdade, na modernidade a verdade é crítica, cujo princípio não é uma verdade eterna, mas a verdade da mudança.

Calcanhotto diz que, durante o processo de elaboração do CD “A fábrica do poema”, pensou em compor uma canção para a arquiteta Lina Bo Bardi, até descobrir que o poeta Waly Salomão já havia escrito um poema para a arquiteta. O poema “A fábrica do poema”, de Waly, homônimo do CD de Calcanhotto, privilegia uma linguagem seca e antimusical, em que desponta a reflexão sobre a criação poética. Nesta canção evidencia-se o primado da metalinguagem: no ato mesmo de criar, o artista expõe seu conceito de criação, ou seja, a linguagem se debruça sobre si mesma, remetendo o código utilizado à língua e a seus elementos constitutivos. Calcanhotto comenta sobre a criação dessa música:

Eu gosto muito da coisa seca mesmo, de cada sílaba ter uma nota e não ficar repetindo, enfim, [...] eu lembro um poema do Waly, muito difícil, que eu musiquei: “A fábrica do poema”, que ele leu pra mim no telefone. Quando ele acabou de ler eu já sabia que música seria aquela. Era a música da leitura dele, na verdade. (In: MATOS; MEDEIROS; TRAVASSOS; 2008, p.45)

A ligação entre poema e música é explorada por Mallarmé, que faz, deste parentesco, um princípio de suas idéias e pesquisas estéticas, meditando-o na crítica e praticando-o na criação poética, cuja ligação é concebida a partir de observações sobre a estrutura e a operação dos dois códigos. Entre a invenção e a dissolução, “A fábrica do poema”, em seu caráter autoreflexivo, explicita a 
tentativa do poeta de erguer seu poema de "arquitetura ideal” que se elabora sob bases movediças.

Waly, desde o primeiro verso, problematiza a questão do diálogo entre a tradição e a modernidade, em que o artista é o esgrimista desencantado que luta com as palavras no universo incontrolável do sonho que, no qual o autor constrói um poema de arquitetura ideal feito de "nata de cimento", as palavras se encaixam perfeitamente. No entanto, deve-se considerar que a obra de um poeta não existe isolada, é resultante da bagagem de informações que ele assimila de seus antepassados.

Nenhum poeta, nenhum artista, tem sua significação completa sozinho. Seu significado e a apreciação que dele fazemos constituem a apreciação de sua relação com os poetas e os artistas mortos. Não se pode estimá-lo em si; é preciso situá-lo, para contraste e comparação, entre os mortos. (ELIOT, 1975, p.36)

O par Waly/Calcanhotto, semelhante a Mallarmé, edifica seu discurso num "poemusical" que pensa sobre sua própria estrutura representada alegoricamente através da imagem do poema-prédio em dissolução que esvoaça como uma página em branco à mercê do vento. Como Gertrude Stein problematizara no verso "Uma rosa é uma rosa é uma rosa”, o "poemusical' produzido na fábrica do poema é "cinza de um corpo esvaído de qualquer sentido", o verso vale por si mesmo, atenta para o próprio suporte, e busca sua força na "carne das palavras” e na “carne dos sons”.

"Minha música” é uma canção manifesto em que Calcanhotto nomeia seu princípio estético musical, e pode ser interpretada como uma espécie de prolongamento da também canção manifesto "Senhas", que deu título ao seu trabalho anterior, cuja postura iconoclasta escancara uma crítica mordaz ao reino das instituições que ditam o "bom gosto", o "bom senso" e os "bons modos”. A artista, através da elaboração de sucessivas negações, vai tentando desconstruir a concepção arcaizante da arte estandartizada. Evidenciando a crise que acentua o binômio tradição/modernidade, Calcanhotto compõe seu discurso revoltado, e diz que gosta "dos que tem fome/Dos que morrem de vontade/Dos que secam de desejo/Dos que ardem”, situando-se num campo estético amplo, envolvendo a arte num caráter geral. "Minha música”, ao contrário, é exclusivamente focada na questão musical, porquanto a artista estabelece os princípios de sua criação, e reincide no primado da reflexão, que objetiva romper com os paradigmas estéticos 
e ideológicos que cerceiam a invenção musical. A música, conduzida numa levada cool, com a atuação do violão, guitarra, bateria e baixo acústico, destaca o diálogo com o legado da tradição jazzística. A força da expressão do canto de Calcanhotto reside na sobriedade de sua interpretação, sem arroubos. Sua voz suave destaca a pungência dos versos em permanente negação. Sua música

\author{
[...] não quer ser útil \\ Não quer ser moda \\ Não quer estar certa \\ Minha música não quer ser bela \\ Não quer ser má \\ Minha música não quer nascer pronta \\ Minha música não quer redimir mágoas \\ Nem dividir águas \\ Não quer traduzir \\ Não quer protestar (In: CALCANHOTTO,1994)
}

No decorrer dos versos, Calcanhotto vai rompendo com uma série de prerrogativas que circundam a gênese da MPB. Ela não instaura nenhuma afirmação, sua canção manifesto se ergue por meio da desconstrução dos pilares essenciais da arte que compreendem questões como o belo e o bom. Do primeiro ao último verso, ela introduz a palavra "não"; a canção é despida pela cantora em todos os seus adjetivos até que se esgote no vazio de uma possível e totalizante “não canção”. A “música pura”, que a compositora proclama, estaria distanciada do mundo massificante da indústria cultural, na qual ela também se insere. Em “Minha música” está embutida a reflexão sobre o lugar ocupado pelo cantor na música contemporânea, pois, conforme preconiza Adorno (1999), o campo que o fetichismo musical mais domina é o da valorização pública das vozes dos cantores: o atrativo exercido por eles vem de longa tradição, assim como a vinculação do sucesso à pessoa do cantor dotado de "bom material”.

A busca pela essencialização é uma das questões primordiais no trabalho de Calcanhotto, é fundamentalmente por meio de suas performances vocais que ela realiza leituras/desleituras de canções e poemas. De acordo com o estudioso Luiz Tatit, o universo da canção tem seu centro na voz, pela voz inflete-se a melodia e articula-se a letra, completando as condições básicas para a concepção de uma obra. A maneira como Calcanhotto utiliza sua voz na exploração de notas graves, médias e agudas exerce total interferência no resultado da canção. Os poemas “A fábrica do poema” e "O verme e a estrela”, ao serem musicados e 
interpretados pela voz da cantora, adquirem um formato e vigor singulares que dizem respeito à performance da artista. A voz carrega uma carga de informações que implicam sugestões sensuais, eróticas e ideológicas. O timbre agudo e a extensão vocal não muito grande de Calcanhotto demonstram um trabalho que se situa na valorização das nuances, pequenos detalhes nas inflexões interpretativas. A artista explora as relações entre a canção e a poesia, fazendo uso da palavra em um apurado exercício de experimentação sonora e estética. Trabalhar nos interstícios do poema é um dos ofícios da artista, que diz gostar

[...] de musicar poemas, tenho feito isso ao longo dos anos. Musiquei alguns do Mário de Sá-Carneiro, a convite da editora Nova Aguilar, no lançamento das obras completas do poeta no Brasil [...] Um desses poemas musicados, "O outro", gravei no meu cd ao vivo e depois no DVD, "Público". De vez em quando canto um ou outro desses poemas nos shows. Mergulhei na obra de Mário de SáCarneiro para musicar os poemas e me tornei fã. $\mathrm{O}$ último poema que musiquei chama-se "Poética do Eremita", da poeta portuguesa Fiama Hasse Pais Brandão. Musiquei no cello. (In: CALCANHOTTO, 2010)

"Maritmo", título que nomeia o quarto trabalho de Calcanhotto, indica o diálogo que a artista estabelece com a poética das águas, mais precisamente do mar. A tematização do mar será plenamente desenvolvida no posterior "Maré", em que ela elabora um CD inteiramente voltado para os mitos, lendas e histórias que envolvem o imaginário poético do mar. Em "Maritmo" Calcanhotto dialoga com artistas como Hélio Oiticica, Dorival Caymmi, Caetano Veloso e Hermeto Paschoal, em músicas que colocam em destaque a reflexão sobre a criação. Ao homenagear o artista plástico Hélio Oiticica em "Parangolé Pamplona", Calcanhotto demonstra ser uma artista que transita entre instâncias artísticas que transcendem o universo exclusivo da música. Sobretudo as artes plásticas estão presentes frequentemente nas obras da cantora, que na elaboração dos encartes, remete a Mondrian, Andy Wahrol, Hélio Oiticica e Hélio Eichbauer. Calcanhotto mostra a habilidade que possui para relacionar diferentes categorias artísticas, pois a seu ver uma obra de arte é tomada de maior riqueza à medida que não restringe seu universo portador de sentido:

[...] as coisas todas para mim são misturas. Gosto dos autores, daquela cabeça, daquele ponto de vista, daquela canção ou daquele quadro, daquele experimento. Tudo isso junto, são coisas que eu gosto. (RODRIGUES, 1995, p.231) 
"Vamos comer Caetano" é uma canção de Calcanhotto que se relaciona com a estética tropicalista. É uma música de caráter antropófago e desconstrutor, em que ela propõe a devoração de um dos mais consagrados artistas da música popular brasileira: Caetano Veloso. Em entrevista concedida ao programa “Ensaio” a artista fala sobre sua identidade com a produção lírico musical do compositor

\begin{abstract}
Caetano me interessa muito, inteiramente, mesmo às vezes as coisas que não concordo muito com ele me interessam. Aquela coisa que ele diz que não é músico, enfim, a questão dele com música é complexa, e eu acho que é tão generoso, ele abre, fala. A gente aprende tanto com isso, e todos os links com o modernismo, as questões de sexo e arte. Caetano é muito forte. (https://www.youtube.com/watch?v=IZnl8xm6o3c )
\end{abstract}

A noção de antropofagia descende da prática dos índios tupis, que consistia em devorar seus inimigos, mas somente os bravos, guerreiros. Nesse ritual realizava-se uma relação com a alteridade, os índios escolhiam aqueles a serem devorados a partir de sua potência vital. No Brasil a antropofagia adquire nos anos 30 um sentido que vai além do ato de devoração praticado pelos índios. O movimento antropofágico encabeçado por Oswald de Andrade extrai e reafirma a fórmula ética da relação com o outro que domina o ritual, fazendo-a migrar para o espaço da cultura. O banquete antropofágico se compõe de universos variados incorporados na íntegra ou em suas partes mais "apetitosas”, tudo misturado livremente num mesmo caldeirão, sem nenhum respeito por categorias hierárquicas.

Oswald de Andrade criou sua concepção antropofágica para problematizar a discussão das questões relativas à cultura e ao poder. Propôs a reabilitação do primitivo no homem civilizado, dando evidência ao mau selvagem, que devora a cultura alheia, transformando-a em própria. Sendo assim quebrou oposições dicotômicas como colonizador/colonizado, civilizado/bárbaro, natureza/tecnologia. Ao sugerir o canibal como sujeito transformador, social e coletivo, ele constrói uma reescritura da história do Brasil e também da própria construção da tradição. Oswald propôs a antropofagia, acolhendo a dúvida acerca da nossa origem, que aparece problematizada na expressão "Tupi or not tupi: that's the question".

A perspectiva antropofágica diluída nos versos de "Vamos comer Caetano", remete-nos a tríade "síntese, invenção e surpresa", defendida no 
Manifesto Pau Brasil, de Oswald. Esses três pilares fundamentais, presentes em seu ideário estético construtivo, são retomados pela cantora em seu projeto musical que estabelece um diálogo com as propostas diluidoras de Oswald. Entre estruturação e diluição, a artista incorpora os preceitos justapostos no manifesto oswaldiano e propõe a devoração de Caetano Veloso, outro artista que incorpora em si as potencialidades dicotomizadas pelo poeta.

Como a época é miraculosa, as leis nasceram do próprio rotamento dinâmico dos fatores destrutivos.

A síntese

O equilíbrio

O acabamento de carrosserie

A invenção

A surpresa

Uma nova perspectiva

Uma nova escala

Qualquer esforço natural nesse sentido será bom. Poesia Pau-Brasil.

O trabalho contra o detalhe naturalista - pela síntese; contra a morbidez romântica - pelo equilíbrio geômetra e pelo acabamento técnico; contra a cópia, pela invenção e pela surpresa.

Uma nova perspectiva [...] (ANDRADE: 1986, p.32)

A idéia de nacionalidade presente no manifesto Oswaldiano corresponde a uma proposição de transformação no modo do repertório poético, que deveria se aproximar da oralidade, que se contrapõe a uma cultura bacharelesca e ornamental. Contra o "lado doutor" e o "falar difícil”, ele se coloca favorável à língua destituída de erudição, natural e neológica, que se enriquece pela “contribuição milionária de todos os erros”. A síntese proposta pelo poeta segue na contramão do excesso, que deve ser suplantado na "cultura de gabinete”. Os adornos e purismos devem sair de cena e ceder espaço para a entrada de uma informação cultural que toque em nossas bases essenciais. Calcanhotto também retoma esta idéia em seu projeto musical, que traz seu retrato mais fiel em "Senhas"

Eu aguento até os estetas

Eu não julgo competência

Eu não ligo pra etiqueta

Eu aplaudo rebeldias

Eu respeito tiranias (In: CALCANHOTTO, 1992)

A cantora, em "Senhas", filia-se ao ideário de Oswald na medida em que elabora um manifesto em forma musical, que expõe seus pressupostos estéticos, 
que também ilustram uma postura de índole iconoclasta. Contra posicionamentos puristas e prerrogativas que impõem critérios de "bom gosto" estético, ela cria seu manifesto revoltado. A inventividade e a surpresa, proclamadas no manifesto oswaldiano, eclodem na criação da artista na maneira como ela dá um tratamento singular às suas elaborações. A inventividade, na obra de Calcanhotto, está sobretudo no seu permanente diálogo com outras categorias artísticas, como a literatura e as artes plásticas.

Caetano Veloso, em seu livro "Verdade Tropical” (1997), elabora uma longa reflexão a respeito da influência Oswaldiana sobre sua criação, em que o Movimento Tropicalista incorpora grande parte das questões propostas pela antropofagia.

A idéia do canibalismo cultural servia-nos, aos tropicalistas como uma luva. Estávamos “comendo" os Beatles e Jimi Hendrix. Nossas argumentações contra a atitude defensiva dos nacionalistas encontravam aqui uma formulação sucinta e exaustiva. Claro que passamos a aplicá-la com largueza e intensidade, mas não sem cuidado, e eu procurei, a cada passo, repensar os termos em que adotamos. [...] Na verdade, são poucos os momentos na nossa história cultural que estão à altura da visão Oswaldiana. [...] A antropofagia, vista em seus termos precisos, é um modo de radicalizar a exigência de identidade (e de excelência na fatura), não um drible na questão. (VELOSO, 1997, p.247, 249)

Como argumenta Caetano Veloso, as questões problematizadas por Oswald de Andrade, mais especificamente a antropofagia, foram alvo de minuciosa análise do escritor e adaptação para o seu processo criativo. Não adotando absolutamente ao "pé da letra" as formulações oswaldianas, mas tentando reinterpretá-las à luz do contexto nacional décadas após a eclosão do "Movimento Pau Brasil" e do "Movimento antropófago", o compositor procura manifestar suas idéias sob uma perspectiva relativista.

O Tropicalismo nasce das discussões estéticas sobre a estagnação da música produzida no Brasil, que, de um lado, encontrava-se refém das formas jazzísticas da Bossa Nova e, de outro, estava fadada a marginalização intelectual na Jovem Guarda, não representando um movimento pensado e organizado. Tudo desponta como resultado das inquietações de Caetano Veloso e Gilberto Gil, do momento de revisão do passado e do desejo do novo. "Domingo no Parque" (Gilberto Gil) e “Alegria Alegria” (Caetano Veloso) levantaram a bandeira tropicalista, assumindo o caráter de devoração cultural da proposta de Oswald de Andrade. Os compositores se propuseram, oswaldianamente a "deglutir" o que 
havia de novo nos movimentos de massa e de juventude e incorporar as conquistas da moderna música popular brasileira ao seu próprio campo de pesquisa.

O título da canção "Vamos comer Caetano” é uma espécie de convite coletivo, realizado por Calcanhotto, para que o público desfrute e absorva antropofagicamente as qualidades nutritivas do compositor :

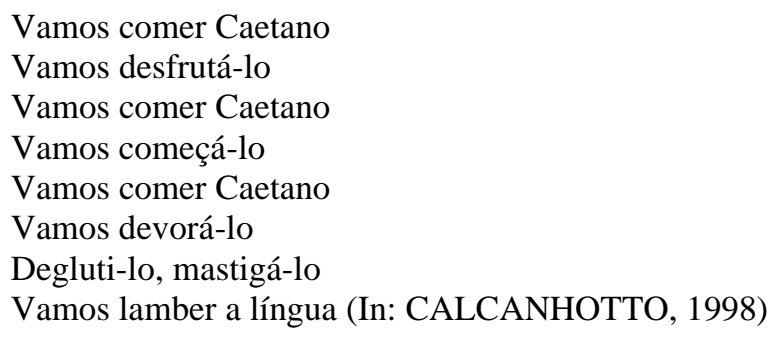

A atitude canibal se dá simbolicamente através do ato de comer, devorar, deglutir Caetano, cuja degustação do gosto de sua língua evoca a composição "Língua”, realizada por ele: “Gosto de sentir a minha língua roçar a língua de Luís de Camões”. Os versos de "Vamos comer Caetano" implicam um jogo de ambiguidades em que a língua se amplia em seus significados, apontando tanto para sua substância de palavra, linguagem, como para conotações sexuais:

\author{
Nós queremos bacalhau \\ A gente quer sardinha \\ O homem do pau-brasil \\ O homem da Paulinha \\ Pelado por bacantes \\ Num espetáculo \\ Banquete-ê-mo-nos \\ Ordem e orgia \\ Na super bacanal \\ Carne e carnaval
}

A referência ao bacalhau alude ao programa do Chacrinha, em que o apresentador distribuía o peixe de maneira divertida entre os participantes da festa marcada pela anarquia. "O homem do pau-Brasil” possibilita-nos três direções interpretativas: a primeira delas diz respeito a um dos primeiros shows montados por Calcanhotto, intitulado “a mulher do pau Brasil”; a segunda evoca a madeira que deu nome ao nosso país; a última donde alude a Oswald de Andrade, autor do “Manifesto da poesia pau Brasil”. 
Calcanhotto compõe "Vamos comer Caetano" a partir de fatos verídicos, como o episódio do desnudamento de Caetano Veloso na tragédia grega de Eurípedes “As Bacantes”, montada por José Celso Martinez Correia. A tragédia narra a tentativa de Penteu, rei de Tebas, de impor sua autoridade sobre os bacanais e desordens associados ao culto de Dionísio (deus do vinho, da abundância, do prazer e também do teatro). Refreando-os a adaptação tragicômica de Zé Celso rompe com o formato do teatro tradicional e instaura a celebração orgiástica do Brasil contemporâneo, pleno de contrastes e exaltações, onde se sobressaem a religião, o rito e o carnaval. Calcanhotto convida o ouvinte para participar da devoração antropofágica de Caetano Veloso: "Banquete-ê-monos/Ordem e orgia/Na super bacanal//carne e carnaval”. Quanto à questão da performance musical, destaca-se a programação de samplers feita por Sacha Amback, que usa na mistura sonora fragmentos de várias músicas interpretadas por Caetano Veloso, como "Livros”, “Gema”, “Tempo de estio”, “Irene”, “Eclipse oculto”, “O homem velho”, "Branquinha”, entre outras.

Calcanhotto canta sobre uma base musical que produz samplers, ou seja, recortes de vinte e três músicas gravadas por Caetano Veloso. Essas composições, ao passarem pelo tratamento do sampler, adquirem uma nova textura musical, são reconfiguradas. Este procedimento de incorporação de variedades sonoras, que se fundem numa massa híbrida de sons, retoma uma das marcas da proposta antropofágica: devoração e consequente síntese. Caetano Veloso realiza este procedimento desde a gravação de seus primeiros discos. “Araçá Azul”, traz uma proposta sonora de caráter experimental, com a inserção de sons aleatórios em várias faixas do álbum. O artista, propositalmente, deixa despontar certo caráter inconcluso do disco. Suas ideias sonoras em formação revelam sugestões, erros e acertos tateados no escuro do estúdio. A canção "Conversa/Cravo e Canela" mostra uma pequena melodia acrescida de uma infinitude de gemidos, grunhidos e barulhos. Décadas após, seu disco “O Estrangeiro" retoma procedimentos experimentais que mostram sua filiação ao ideário oswaldiano, expresso desde a configuração da capa do encarte, que traz como ilustração uma maquete realizada pelo artista Hélio Eichbauer para o segundo ato de “O rei da vela”. Este cenógrafo que foi responsável pela concepção visual da peça, torna-se presença constante nos trabalhos de Calcanhotto. 
No início de "Vamos comer Caetano" identifica-se uma harmonia que se dá por meio do desempenho da guitarra elétrica, entretanto quando Calcanhotto inicia seu canto ouve-se uma base rítmica constituída unicamente por instrumentos percussivos que vão sendo sobrepostos ao desenvolvimento da canção, levando esta a ser classificada como uma espécie de "axé-music”. A voz de Calcanhotto introduz a canção de maneira seca, quase falada e manifesta um ganho de intensidade interpretativa na medida em que a música vai crescendo em vibração rítmica. O som das palmas associado aos atabaques cria uma ambiência rítmica que ora evoca um ritual de origem africana, como o Candomblé, ora a brasilidade do ritmo de uma escola de samba. A voz de Calcanhotto sobressai em destaque, dando ênfase aos versos, ao mesmo tempo em que se mistura com a sonoridade intencionalmente "suja” da base. A interpretação da artista é mais vigorosa quando o ritmo se torna mais pulsante. Como reflete Tatit, uma das questões fundamentais a ser levada em conta quando se trata de avaliar a sonoridade brasileira na forma de canção é a oscilação entre canto e fala. Nota-se, no canto de Calcanhotto, o princípio entoativo destacado por Tatit, que consiste na adequação absoluta entre melodia e letra, na qual a melodia mimetiza a entoação da fala, respeitando a prosódia e a duração do som das palavras na fala, por meio de uma correspondência quase direta entre sílaba e nota musical.

Calcanhotto canibal devora, deglute e assimila o também antropófago Caetano Veloso, que por si só constitui uma presa que possui em si uma gama de influências.

\author{
Pelo óbvio \\ Pelo incesto \\ Vamos comer Caetano \\ Pela frente \\ Pelo verso \\ Vamos comê-lo cru
}

Mais do que digerir o "inimigo" Caetano, Calcanhotto, ao assimilar o ícone da música popular brasileira, torna-se autora de uma obra cuja originalidade estabelece uma filiação com Caetano. Ela convida o ouvinte de sua música a olhar para a criação de Caetano através de seus olhos.

"Público" consiste no primeiro disco da artista gravado inteiramente ao vivo, acompanhada unicamente por seu violão ela interpreta canções já consagradas de seu antigo repertório como "Esquadros”, “Cariocas”, "Vambora” e 
“Mais feliz”. Calcanhotto dá ênfase a uma interpretação minimalista que conduz tanto sua performance vocal, quanto o desempenho de seu violão que privilegia acordes dissonantes. A influência da estética bossanovista neste trabalho se faz presente em toda a sua performance; a voz e violão se comunicam numa relação de complementariedade: nem o violão é virtuoso em sua sequência de acordes e nem a voz excede a suavidade que se faz lema. Há que se frisar que a tríade voz, banquinho e violão marca a composição do estilo Bossa Nova que remete a João Gilberto, Nara Leão, Carlinhos Lyra e Rosa Passos. Em "Público", nota-se a evidente interação público/artista a qual sobressai pelo diálogo que Calcanhotto estabelece com a plateia: Desta forma, a performance de cunho minimalista da cantora se expande à medida que se constrói na relação com o público.

"Cantada” é o sexto CD da carreira de Adriana Calcanhotto, e, como sugere o título, trata-se de uma obra permeada por jogos de sedução, já que o termo remete a encantar, seduzir, enlevar, extasiar. Dessa forma, esses são os propósitos da artista, que, da primeira à última faixa, conduz a sedução como roteiro de sua viagem lírica. Este álbum traz a voz de Calcanhotto num registro predominantemente cool . Quase todas as faixas compõem uma atmosfera intimista em que os arranjos valorizam a sonoridade da voz da cantora, que se projeta muito suave, dando destaque à essência lírica dos versos. Em "Jornal de serviço”, Calcanhotto utiliza a literatura como alvo de experimentação; este longo poema de Carlos Drummond de Andrade, extraído das páginas amarelas de um jornal, sofre a intervenção musical da artista. No intuito de manter o seu caráter seco e incisivo, ela opta por não musicar os versos, cuja base de acompanhamento da leitura se constrói numa mistura de bossa e batidas eletrônicas produzidas pelo grupo Bossacucanova, o qual cria uma cadência sonora que potencializa a força dos versos lidos pela artista. Em termos de performance vocal, "Cantada" caracteriza-se como extensão de “A fábrica do poema”, sendo que a efusão lírica aparece por meio de contínuos jogos de sedução.

"Maré", trabalho que se segue a "Cantada”, é um CD inteiramente dedicado à poética do mar no qual Calcanhotto celebra os encantos e mistérios das sereias, dos mares e dos homens. Destaca-se neste álbum um considerável amadurecimento em seu modo de cantar, resultante de conquistas técnicas e também existenciais. De "Enguiço” até "Maré” é evidente a transformação na expressividade do canto de Calcanhotto. "Maré” mostra uma cantora que, no 
decorrer de sua carreira, aprendeu a utilizar seus próprios recursos vocais, revelando um aprimoramento artístico para o qual contribuíram as parcerias estabelecidas com outros compositores e os trabalhos desenvolvidos com diversos instrumentistas. Em cada gravação, é visível o colorido do timbre que se dá por meio da escolha da tonalidade ideal e da respiração adequada. Vale frisar que a emissão vocal acontece concomitantemente a uma série de eventos corporais de ordem interna e externa. Para que a voz seja produzida pelo corpo todo cantor faz uso dos pulmões, músculos abdominais, diafragma, laringe, faringe, traqueia, cordas vocais, língua, lábios e músculos faciais. Os órgãos da respiração são o motor da voz, conduzem todo o processo em que o ar que por eles circula é o combustível. Calcanhotto ao aliar a técnica à intuição emotiva, constrói um trabalho maduro.

"Partimpim” é um cd com uma proposta diferenciada em relação aos demais trabalhos de Calcanhotto. A artista metamorfoseia-se na criação do heterônimo Partimpim e diversifica seu universo musical, privilegiando o lúdico e a inventividade. Partimpim aproxima-se do mundo infantil por meio de sua performance e um figurino que incorpora muitas cores, formas e acessórios. É um álbum que explora uma multiplicidade rítmica que vai de encontro ao ouvido das crianças, sem no entanto se encerrar num formato estritamente destinado a este tipo de público. O repertório inclui versões cheias de swing para músicas como "Lig-lig-lig-lé”, "Lição de baião" e "Formiga Bossa Nova”. A valorização do substancial lírico é predominante nas interpretações cujos arranjos incorporam ritmos e levadas distintas, sem jamais suplantar a força das palavras, como evidencia “Ciranda da bailarina”. A performance vocal da Partimpim nesta composição de Edu Lobo e Chico Buarque dá ênfase ao caráter poético da música, que, em seus versos, instiga o imaginário das crianças :

\author{
Procurando bem \\ Todo mundo tem pereba \\ Marca de bexiga ou vacina \\ E tem piriri, tem lombriga, tem ameba \\ Só a bailarina que não tem \\ E não tem coceira \\ Verruga nem frieira \\ Nem falta de maneira \\ Ela não tem (In: CALCANHOTTO, 2004)
}


“Partimpim II" dá continuidade à proposta do primeiro álbum, porém amplia ainda mais a performance da intérprete reunindo um repertório que seduz principalmente o público adulto. “Alexandre”, de Caetano Veloso, chega até o ouvido das crianças auxiliado pela performance da Partimpim que inventa seu cenário épico-lúdico no palco. "Bim Bom”, canção antologizada na interpretação bossanovista de João Gilberto, ganha uma versão rica em experimentações rítmicas realizadas por Calcanhotto, auxiliada pelos músicos Moreno Veloso, Davi Moraes e Domênico Lancelote.

Em "Micróbio do samba" a voz de Calcanhotto se mantém sob o domínio de um equilíbrio constante. A preocupação com a limpidez do canto, que persegue grande parte de suas interpretações, numa busca obsessiva, é fator dominante nesta obra. Entretanto não se trata de um canto absolutamente cool, contido, que reproduz uma filiação à estética bossanovista, visto que a cantora se mostra mais expansiva com suas habilidades vocais, embora não apele para malabarismos e muito menos para modulações excêntricas com vibratos. Calcanhotto canta procurando deixar despontar o legado que subjaz a cada composição, num álbum de samba que na verdade não se propõe a ser samba, em harmonia com uma voz que também não objetiva enquadrar-se no estilo.

Em entrevista a Márcio Debellian, a artista revela a senha de sua postura: "Eu quero continuar sendo uma impostora de música como eu sou”. Essa identidade meio "camuflada” na qual a cantora se nomeia perfaz sua estratégia criativa, assumir o violão sem ser uma instrumentista efetivamente munida por grandes recursos técnicos e interpretar canções próprias e alheias sendo uma cantora destituída de um grande volume de voz ou de performances virtuosas. O caráter híbrido que pontua as criações de Calcanhotto que dialogam permanentemente com o cancioneiro nacional e com artes como literatura, artes plásticas e cinema se faz presente no ideário construtivo de "Micróbio do samba”, disco revelador da diversidade de influências que inspiram as criações da artista.

A cantora deixa a voz soar sutilmente irônica em determinadas ocasiões, a exemplo da canção "Deixa gueixa”, que remete às antigas marchinhas de carnaval como “Abre Alas” (Chiquinha Gonzaga), “Mamãe eu quero” (Jararaca e Vicente Paiva) e "O teu cabelo não nega” (Lamartine Babo e Irmãos Valença). Calcanhotto põe em evidência o colorido da canção através da escolha de uma tonalidade adequada e da elaboração de um arranjo de base que dá suporte a sua 
extensão vocal. Sua voz não excede em vibratos ou modulações e Calcanhotto explicita o caráter poético dos versos através de um canto voltado para uma expressão mais intimista, em que toda a moderação tanto no arranjo, como no seu desempenho e no dos músicos se faz almejando um música síntese que incorpore nuances criativas, sutileza, sobriedade e refinamento. "Deixa gueixa” abre igualmente um diálogo com a linhagem das grandes cantoras do rádio (Emilinha, Marlene e Carmen Miranda), porém Calcanhotto imprime sua rasura vocal na medida em que relê o estilo a sua maneira:

Deixa, gueixa, deixa Deixa eu te fazer o chá Deixa, gueixa, deixa Deixa eu lavar a louça

de bandeja eu te daria se ao meu alcance o lance da alegria

o presente deste instante

[...] é assim no ocidente (aqui no Leme)

e eu te explicaria

tim-tim por tim-tim pudesse

nunca mais tu chorarias (In: CALCANHOTTO, 2011)

Na estrofe inicial a cantora elabora uma brincadeira sonora através da aliteração em que o som /ch/ se repete nas palavras deixa, gueixa e chá produzindo o efeito de humor que é típico das marchinhas. A artista retoma o estilo de composição do gênero, que se verifica pelo formato da base e pela introdução de um coro que remete às clássicas gravações. É comum a presença de um coro na estrutura das tradicionais marchinhas, em que o cantor canta dialogando com o coro, que em geral repete unicamente o refrão no decorrer da música. "Yes, nós temos bananas”, de Braguinha e Alberto Ribeiro, gravada por Almirante em 1937, conta com a presença do coro que estabelece um diálogo bem fortalecido por algumas expressões como "pois é” e "pois não”, os quais reforçam a inteiração coro/cantor:

Yes, nós temos bananas Bananas pra dar e vender Banana menina tem vitamina Banana engorda e faz crescer 
Vai para a França o café, pois é

Para o Japão o algodão, pois não (grifo nosso)

Pro mundo inteiro, homem ou mulher

Bananas para quem quiser

Mate para o Paraguai, não vai

Ouro do bolso da gente não sai

Somos da crise, se ela vier

Bananas para quem quiser (http://www.youtube.com/watch?v=Ou_N7ajW96I)

Em "Yes, nós temos bananas” (da gravação original, de 1937), o refrão constitui-se na primeira estrofe e se repete a princípio duas vezes com a interpretação do coro, enquanto o cantor Almirante inicia sua interpretação a partir da segunda estrofe. Devido à forma acentuadamente irônica com que expõe os problemas políticos do país, "Yes, nós temos bananas" recebeu várias interpretações ao longo dos anos, incluindo a gravação de Caetano Veloso, na década de setenta. As marchinhas possuem um andamento rápido, compensado pelas recorrências, ou seja, suas letras costumam descrever uma única situação, que às vezes se expande em comentário, mas sempre retornando ao estágio inicial. "Deixa gueixa” não foge à regra: Calcanhotto evolui cantando os versos, mas sempre volta ao ponto inicial, fazendo com que o ouvinte disponha de um nível de previsibilidade, criando, assim, uma rotina no interior da canção.

O desempenho vocal de Calcanhotto se distancia das interpretações expressionistas de cantoras como Carmen Miranda e Dalva de Oliveira, que gravou de maneira arrebatada "Bandeira Branca”. O único registro comercializado em VHS de Calcanhotto mostra o show que realizou no Teatro Rival no início dos anos noventa. Acompanhada unicamente por seu violão, a artista abre o espetáculo cantando "Bandeira Branca", dando ênfase a uma interpretação peculiar que segue na contramão do modo expansivo e privilegia a emissão vocal num canto destituído de excessos. Confirma-se então que há mais de uma década Calcanhotto já havia feito uma releitura "exótica” de uma marchinha consagrada.

A voz de Calcanhotto em "Deixa gueixa" mostra um percurso em que predomina a linearidade, não há significativos movimentos de aclives e declives, dado que seria natural na interpretação de uma marchinha que evolui por meio do acréscimo da emoção que resulta na contínua expansão da voz. Os intérpretes das marchinhas de carnaval tradicionalmente costumam evidenciar uma progressão no movimento da voz responsável pelo entusiasmo que contagia o público 
carnavalesco, que responde com descontração e malícia. Calcanhotto brinca com as palavras e, quando se junta ao coro, prossegue seu canto sem manifestar significativa alteração vocal, mantendo sua voz no mesmo grau de tensividade com o qual iniciou a interpretação. Seu canto prioriza a contenção expressiva, trazendo para as suas composições uma das características fundamentais ao samba, que é o lugar de destaque dado à palavra. A artista procura de certa maneira manobrar o canto na tangente da fala, o que inscreve seu procedimento musical na linhagem dos sambistas, pois conforme Tatit eles

[...] ao mesmo tempo que atribuíam independência à melodia, unificando suas partes com dispositivos musicais, conservavam seu lastro entoativo para dar naturalidade à elocução da letra.” (TATIT, 2008, p.42).

A presença de uma oscilação entre canto e fala contamina o samba, principalmente o samba de breque, que alterna canto e fala na sequência de uma obra, sem jamais privilegiar apenas uma modalidade. Canto e fala existem simultâneos, como exemplificam as músicas interpretadas por Moreira da Silva. As canções de Moreira da Silva são repletas de humor expresso no estilo despojado das letras, no "swing" e na performance do cantor. Calcanhotto não faz uso do canto/fala à moda do samba de breque, pois não evidencia instantes de pura fala que se alternem com o canto: o que a cantora expressa em grande parte de suas interpretações, em "Micróbio do samba", é um canto seco que se aproxima consideravelmente da fala. “Tá na minha hora” demonstra explicitamente a performance do canto/fala de Calcanhotto na última estrofe, em que ela coloca a mulher como autora do discurso, revelando novamente a quebra da estrutura tradicional do samba, que costumava dar ascendência à figura masculina. Essa mulher emancipada deixa um recado para seu homem, e Calcanhotto, neste canto/fala, reforça a advertência:

\author{
te deixo a geladeira cheia e sem promessa \\ que findo o carnaval eu tô de volta \\ não chora, neguinho, não chora \\ o meu coração é verde e rosa \\ não chora, neguinho, não chora \\ tá na minha hora, tá na minha hora (In: CALCANHOTTO, 2011)
}

As interpretações de Calcanhotto, além de traçarem um diálogo com o ideário do samba, também fazem remissão ao histórico das cantoras dotadas de 
grande expressividade, como Dalva de Oliveira, Carmen Miranda, Emilinha Borba e Marlene. Estas artistas expandiram seus talentos cantando no rádio, que era o principal veículo de entretenimento e informação da época. Adoradas pelo grande público como verdadeiras rainhas, estas cantoras da época de ouro do rádio acrescidas de outras como Ângela Maria, as irmãs Linda Batista e Dircinha Batista, elevaram o status do canto feminino e serviram de paradigma de qualidade para cantoras da geração seguinte. Elis Regina, por exemplo, fez questão de declarar a influência que Ângela Maria exerceu sobre sua maneira de cantar

Realmente devo ter descoberto que podia ser cantora devido a Ângela Maria, comecei minha carreira de cantora imitando descaradamente a Ângela Maria. Até hoje em certos momentos das minhas apresentações eu saco na minha voz a voz da Ângela Maria e tenho profundo orgulho disso. A Ângela Maria é realmente pra mim a maior cantora que o Brasil já teve. (http://www.youtube.com/watch?vq2ubszZ-8I)

Calcanhotto reverencia o legado das grandes cantoras da era do rádio, porém não reproduz em seu canto o estilo de cantar comum àquelas mulheres. As rainhas do rádio eram artistas que se esmeravam em explorar as potencialidades da voz, numa época em que ainda não existia uma tecnologia que possibilitasse aos portadores de "voz pequena" cantarem profissionalmente. Faziam parte do cast da rádio exclusivamente cantores dotados de grande extensão vocal. Uma atmosfera de glamour e competitividade envolvia o universo das cantoras do rádio. A glamourização se devia sobretudo à sedução produzida nos ouvintes por meio do recurso exclusivo das vozes femininas, pois não havia ainda a televisão, que traria a visão da performance em sua totalidade. O ouvinte se mantinha atento ao desempenho da voz e da música, mas a visão era um sentido pouco estimulado, uma vez que somente no cinema se podia ver algum cantor da rádio.

Calcanhotto é uma cantora que surge numa geração mais adiante, posterior à eclosão da Bossa Nova, que já havia rompido com o modo expressionista de cantar que valorizava a emissão da voz em grande extensão, plena de arroubos dramáticos, característica das cantoras e cantores do rádio. O estilo cool de cantar teve João Gilberto como seu mestre absoluto no Brasil, pois nos Estados Unidos já haviam aparecido Chet Baker e Julie London, com seus estilos de cantar softy e contidos. A técnica de cantar joãogilbertiana privilegia o tom de voz uniforme, emissão vocal sem vibratos, sobrecarga interpretativa, ou qualquer excesso. A 
proposta estética e sonora de João Gilberto resultou na antítese do ideário dos cantores do rádio, entretanto este artista, ao longo de sua carreira elabora releituras de clássicos dos anos trinta e quarenta. A revolução musical instaurada por João Gilberto é responsável por uma gama de artistas por ele influenciados no Brasil e no exterior, como Caetano Veloso, Gilberto Gil, Stan Getz, Sade, Rosa Passos, entre outros.

Mesmo com toda a transformação sofrida na performance dos cantores a partir de João Gilberto, torna-se importante frisar que o caminho aberto pelas cantoras do rádio tem como uma de suas mais fieis discípulas a cantora Maria Bethânia, grande diva dos palcos com suas interpretações vigorosas. A voz telúrica e peculiar de Bethânia é grandiosa em projeção não somente devido ao seu timbre "exótico", mas por constituir-se parte integrante e indissociável de suas performances, marcadas por um caráter expressionista. Em "Micróbio do samba” Calcanhotto projeta ecos da memória da tradição das grandes vozes do rádio visando um amplo diálogo com as bases de formação da música popular brasileira.

O diálogo com a tradição das grandes vozes se produz de modo mais explicitamente irônico e dessacralizante na canção "Disseram que eu voltei americanizada”, composição consagrada na voz de Carmen Miranda. Nesta interpretação Calcanhotto faz sua apropriação da música acentuando uma expansividade interpretativa que remete à performance exótica da "Pequena Notável”. Carmen Miranda foi a cantora popular de maior sucesso no Brasil dos anos trinta e se transformou num ícone representativo da nacionalidade brasileira cuja imagem foi difundida mundialmente. Esta artista divulgou símbolos, ideias e estereótipos que foram consumidos por uma grande parcela da população. Assim como outros cantores da sua época, Carmen Miranda interpretava canções que davam destaque ao tema da nação. No decorrer de sua carreira, o tema do nacionalismo se fez presente tanto nas letras interpretadas pela cantora como em sua performance excêntrica, explicitada no figurino composto por bananas na cabeça e nas saias coloridas que remetiam à tropicalidade brasileira. Nas canções interpretadas por Carmen Miranda, despontam referências à natureza que imprimem o sentimento de pertencimento à pátria, como o samba "Tarde na serra”, de Mário Reis: 
É tarde! É tarde! O sol vai morrendo atrás da serra

Como é linda a nossa terra! Que céu de anil!

Os pássaros vão em revoada saudando o Brasil (www.youtube.com/watch?v=aw801buth)

Calcanhotto então brinca justamente com essa exacerbação ufanista, ao entoar o verso num tom de ironia: "Eu sou do camarão ensopadinho com chuchu”. Em "Disseram que eu voltei americanizada”, ela aproveita a sugestão dos versos para intensificar sua interpretação revestida de propositais excessos e irregularidades. A ironia marca a performance de seu canto, que brinca com a afinação e o ritmo. O arranjo e o piano de Wagner Tiso valorizam a dissonância: quebra-se a estrutura harmônica quadrada correspondente à interpretação de Carmen Miranda e exalta-se um percurso sonoro repleto de propositais irregularidades. Sem obedecer a uma condução linear, Wagner Tiso cria tensões e distensões que se alternam. A eleição de acordes dissonantes permite uma maior liberdade expressiva na interpretação de Calcanhotto, que impõe suas próprias acentuações, sua assinatura. A cantora possui o registro de soprano, revelando portanto um potencial vocálico inclinado à exploração de tons mais altos. O que fez nesta música, abusando de entonações muito agudas que soam destoantes, desafinadas. A estranheza que toca o ouvinte é resultante dessa inscrição rasurante realizada por Calcanhotto, que relê a tradição impondo sua marca, pois, ao incorporar a canção do passado ao seu domínio de cantora, reinterpreta-a. Ela brinca com timbragens e texturas, exacerba a pronúncia das palavras no fim de alguns versos numa comicidade quase caricatural. Alguns traços comuns ao canto da era do rádio são reproduzidos ironicamente pela artista, como acontece com a pronúncia exagerada do "r" vibrante, marca que foi abolida pelos cantores da geração Bossa Nova. A evidência deste " $r$ " vibrante se realiza em todas as cantoras da época de ouro da rádio, como Ângela Maria, Carmen Miranda, Dircinha Batista, Linda Batista e Dalva de Oliveira. Essa marca vocal não se reduzia exclusivamente à música, mas também se fazia presente no teatro e na oralidade cotidiana. Embora o traço do "r" vibrante fosse marcador do padrão da pronúncia do português na época de Carmen Miranda e das demais cantoras, há que se registrar que ocorriam variações regionais na realização do mesmo som, de forma que, fora do registro culto adotado para a locução radiofônica, para o canto e o teatro, em diversas regiões, como o Rio de Janeiro e cidades do nordeste, em 
contexto de fala espontânea, não se registra o mesmo modo de concretizar a vibração do "r". Um dado relevante em relação ao "r" vibrante é o fato de que ele costumava marcar o ritmo. A maneira como cada cantora elaborava a pronúncia e até o prolongamento sonoro desse “ $\mathrm{r}$ " resultava em sua singularidade interpretativa. As cantoras Ângela Maria e Dalva de Oliveira, cada uma a seu modo, possuíam uma característica própria na pronúncia do "r" vibrante na palavra cantada. Calcanhotto inscreve seu diálogo com a tradição por meio da pronúncia acentuada do "r" vibrante na releitura de "Disseram que eu voltei americanizada”, outrora gravado por Carmen Miranda:

Com o burro do dinheiro

Que estou muito rica

Que não suporto mais o breque do pandeiro

E fico arrepiada ouvindo uma cuíca. (grifo nosso) (In: CALCANHOTTO, 1990)

Calcanhotto brinca com as palavras, acentuando aclives e declives, os aclives podem ser constatados nos momentos em que a cantora alcança notas mais altas e os declives quando ela modula sua voz atingindo notas mais graves. As cordas vocais emitem suas frequências por meio de vibrações. A produção de um som agudo se faz com vibrações aceleradas e cordas vocais esticadas cujas condições fisiológicas do cantor encontram-se em alto grau de tensividade, enquanto o som grave é resultante de cordas vocais distendidas e da redução na frequência de vibrações. Conforme analisa Tatit (TATIT, 2007, p.172), nas inflexões melódicas, há sempre um percurso contínuo ligando a região grave à região aguda, e vice versa, de forma que o cantor sempre está vivendo um processo de tensividade. As cordas vocais, por não resistirem por um longo tempo no estado agudo de tensividade, procuram um repouso na região grave. $\mathrm{Na}$ interpretação de "Disseram que eu voltei americanizada", Calcanhotto acentua a estridência nos momentos em que entoa notas agudas, fazendo sua voz soar desafinada, sobretudo na entoação do verso: "Eu sou do camarão ensopadinho com chuchu”, em que um agudo estridente parodia a voz de Carmen Miranda. A cantora acentua ainda mais sua leitura caricatural ao cantar os mesmos versos pela segunda vez, forçando o agudo estridente em "zum zum” e trocando a palavra “mim”pela francesa "moi” no verso "mas pra cima de mim, pra que tanto veneno". 
Deve-se ressalvar que é responsabilidade do intérprete o rompimento ou não com os protocolos que presidem a concepção harmônica de uma canção. Alguns cantores optam pela quebra da estrutura formalizada, imprimindo um desenho oposto que se efetua por meio de uma interferência dissonante, com o deslocamento de um fonema para o entrelugar do semiton. Diniz (2003) denomina este procedimento de "poética da dissonância”, que tem em João Gilberto um dos mais significativos modelos. A experimentação de João Gilberto é essencialmente rítmica; ele reestrutura padrões e agrupa-os de formas diversas, elaborando novas concepções de timbre, durações, alturas e intensidades. Uma das estratégias criadas pelo músico consiste num breve deslocamento da frase original de uma música, acarretando novos acentos, produzindo uma leve sensação de polirritmia que gera a originalidade e o balanço peculiares a este intérprete. João Gilberto neutralizou a potência da voz até então exibida pelos intérpretes, pois sua estética dispensa a intensidade e tudo o que possa demonstrar exacerbação sentimental. Ele canta como se fosse em direção ao fundo do silêncio das coisas, objetivando deixar o seu som aparentemente mínimo, o que verdadeiramente é o máximo permitido pelo silêncio. João Gilberto, com sua voz/ lâmina afiada, se dirige rumo à exatidão, ao não excesso, à limpidez de uma estética que valoriza o "menos”, mas que, em sua grandiosidade, constrói uma imensidão sonora. João vigora num universo atemporal, no sentido de que para ele o velho e o novo não se opõem, mas se unem na sua unidade criativa. Ele prossegue seu percurso sem abandonar suas canções e sua renovação se faz constantemente na alteração de cada aparente ínfimo detalhe. Ele insistentemente inventa o novo dentro do antigo e assim continuamente se reinventa dentro de sua totalidade criadora. Nas palavras de Tatit,

[...] se por um lado João Gilberto decantou a canção brasileira de qualquer característica muito acentuada, até mesmo dos procedimentos virtuosísticos da música norte-americana, por outro, reprogramou em seu artesanato impecável de violão e voz a gênese de todos os estilos, passados e futuros. No que se refere ao passado, o próprio intérprete vem "recompondo" em sua diç̧ão um número enorme de sambas e canções de modo geral, por vezes de outra nacionalidade, que fizeram parte de sua vida. (TATIT, 2008, p.51)

Como descreve Tatit, João Gilberto rompe a fronteira entre o passado e o presente ao elaborar sua leitura singular para composições que percorreram sua existência desde a infância. Orlando Silva, Herivelto Martins, Haroldo Barbosa, 
Newton Mendonça e Tom Jobim são alguns compositores que figuram entre suas gravações. João Gilberto é um “ourives” musical; remodela uma mesma música diversas vezes no seu projeto insaciável e inesgotável de extrair o absoluto do som.

Em “E o mundo não se acabou”, composta por Assis Valente na década de trinta do século passado, Calcanhotto elabora outra leitura rasurante de uma canção clássica na voz de Carmen Miranda:

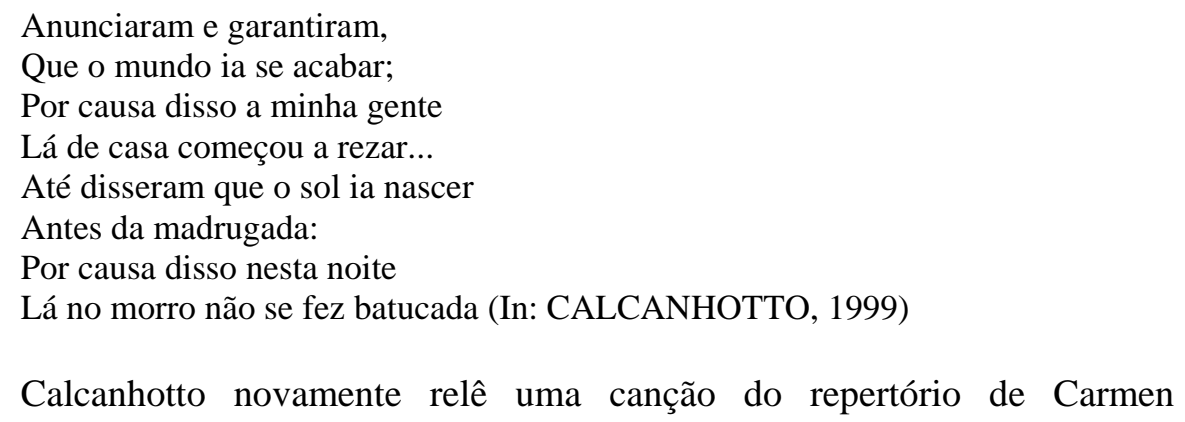
Miranda, mas neste caso com uma tônica diferente de "Disseram que eu voltei americanizada”. Se na canção anterior ela privilegiara uma interpretação vocal mais exacerbada, nesta a cantora dá ênfase a uma interpretação de feição minimalista em que sua voz se projeta de maneira mais contida em equilíbrio com o seu violão, que privilegia uma harmonia simples, sem muitos rebuscamentos e virtuosismos. Calcanhotto canta os versos permeados de humor, acentuando uma interpretação destituída de excessos. No decorrer da canção, não há momento de exaltação ocasionado por alguma ascendência ou descendência tonal brusca. Vale frisar um aspecto que influencia tanto o registro de "Disseram que eu voltei americanizada" quanto "E o mundo não se acabou": ambas consistem em gravações ao vivo, momento único em que se tem a participação calorosa do público que influencia consideravelmente o desempenho do artista. Há vantagens e desvantagens no registro ao vivo, a vantagem maior reside justamente nessa possibilidade de captar a emoção in natura; a desvantagem é que nem sempre se pode remediar as falhas que ocorrem durante o instante do registro. O estúdio também é um importante aliado da voz gravada ao vivo, pois o material registrado na apresentação ao ser levado para o estúdio, sofre uma série de intervenções que visam ao seu aprimoramento. Sobretudo quando o técnico de som tem em suas mãos vários registros ao vivo de um mesmo show realizado por um artista em 
ocasiões distintas, abre-se a possibilidade do alcance de um ótimo resultado final decorrente da mixagem. A voz projetada ao vivo, num teatro, difere da voz colocada em estúdio, mais trabalhada, em decorrência do tempo e disponibilidade para um tratamento mais cuidadoso. O estúdio é o lugar da criação em que se pode refazer a voz inúmeras vezes, até que se alcance o resultado almejado. Cortes, mixagens, inserções, masterizações, todos esses recursos estão à disposição do artista no estúdio, enquanto a gravação ao vivo sai na frente exclusivamente por ter a força da emoção in natura. Felipe Abreu, preparador vocal de Calcanhotto, argumenta sobre a diferença do desempenho da voz no show e em estúdio:

Microfone de estúdio é muito diferente de microfone de show. Em estúdio você pode alcançar notas mais graves. No show elas simplesmente não vão chegar, não vão ultrapassar. Isso é uma coisa que as pessoas geralmente não sabem, mas é muito comum. Canta-se num tom no estúdio e em outro tom no show. Não todas as músicas, mas algumas. (In: MATOS; MEDEIROS; TRAVASSOS, 2008, p.50)

A estética do canto popular urbano ocidental está intrinsecamente ligada à questão tecnológica. Questões referentes à aparelhagem de som e expedientes eletrônicos e digitais constituem um aspecto fundamental no resultado da performance de um artista. O microfone, recurso indispensável ao cantor na atualidade, se divide em seis tipos: dinâmico, condensador, condensador eletreto, fita, carbono, piezo-elétrico. Dentre estes seis, os mais usados pela grande parte dos músicos são os dinâmicos e os condensadores. Os microfones dinâmicos são os mais comuns: eles se assemelham a uma espécie de pequeno autofalante e se sobressaem pela versatilidade, pois são mais resistentes aos golpes e os que menos captam sons de ambiente. Os microfones dinâmicos podem ser utilizados em todas as aplicações, tanto ao vivo como em estúdio. Com relação à qualidade, os microfones dinâmicos deixam um pouco a desejar em comparação à eficácia dos condensadores. Os microfones condensadores se equiparam aos dinâmicos em termos de frequência de uso: consistem num diafragma de plástico revestido com um pequeno banho de ouro, montado sobre um metal condutivo em que o diafragma e o metal estão separados por uma pequena capa de ar que se transforma num componente elétrico chamado capacitor ou condensador. O microfone condensador é o mais indicado para resultados com definição de qualidade, pois ele é o mais sensível à qualquer interferência externa, 
possibilitando ao operador da mesa de som um trabalho mais aprimorado no momento de mixagem e masterização. Toda uma tecnologia cada vez mais sofisticada só se torna de fato aliada do artista se ele souber adequá-la a seu estilo e características individuais. Uma mudança de produtor na carreira de um artista pode tornar-se desastrosa, visto que o produtor, ao tentar elaborar uma transformação radical no artista, pode destruir as características singulares que compõem sua personalidade. Na gravação de um disco, por exemplo, várias etapas se cumprem, como a escolha do estúdio, definição do repertório, seleção dos músicos, elaboração dos arranjos, mixagem e masterização. Todas as fases são imprescindíveis na feitura de uma obra. Não raro se observam num CD, problemas relativos à mixagem que resulta numa sonoridade muito alta dos instrumentos suplantando o desempenho da voz.

A partir da evolução dos microfones a voz dos cantores passou a apresentar uma variedade tímbrica maior. Deve-se levar em conta o fato de que o ideal purista clássico que exaltava a pureza absoluta da voz foi substituído pela concepção moderna, que incorpora os ruídos na voz (as impurezas, a rouquidão, a soprosidade, os gritos, os sussurros). O universo caótico das grandes cidades passa a ser incorporado pelas canções que não se fecham mais no paradigma beleza= pureza. Calcanhotto ilustra em muitas de suas composições a incorporação de “sujeiras sonoras” que revelam a assimilação de vários sons aleatórios e exóticos, oriundos de múltiplos barulhos, especialmente do universo das ruas. Esta incorporação tem se tornado frequente em muitos artistas contemporâneos. Caetano Veloso, por exemplo, em "Estrangeiro", misturou uma diversidade de sons aleatórios que remetem ao mundo dos múltiplos e desconexos sons das cidades.

Calcanhotto relê a tradição por outras vias além do humor. Uma delas é o romantismo, que pontua uma série de interpretações da cantora. O sentimentalismo que envolveu o cancioneiro nacional nos anos 40 e 50 é retomado pela cantora através de composições que trazem aspectos comuns às composições daquela época, como conflitos amorosos, amores não correspondidos, manifestações de revolta e descontrole emocional. Essas músicas passionais caracterizam-se por percursos melódicos que buscam o máximo de tensão. Os elementos de instabilidade do universo musical dão margem ao despontar de uma tônica que evidencia a ansiedade, o desespero e a dor. A tensão 
concentrada tanto no conteúdo dos versos como na evolução da melodia é ressaltada na tensão exibida no deslizamento da voz que vai de um som grave a outro bem agudo, mantendo-se neste. Essa brusca mudança de registro constitui um dos procedimentos clássicos para despertar uma reação passional no ouvinte. As construções melódicas buscam o máximo de contraste entre tensão e repouso e nesse movimento acentuam a impressão de que o próprio percurso melódico já traz em si um grande esforço, um sofrimento em sua realização. O arranjo e os instrumentos que compõem essa modalidade musical dão prosseguimento ao clima de tensão em que os violinos plangentes e a emissão operística das vozes impostadas com volume dão ênfase à dramaticidade e ao uso dos vibratos, além do movimento ascensional com a expansão vocálica dos agudos. Muitas músicas de fossa consistem em "histórias cantadas" em que um narrador explícito pode incorporar o papel do homem traído, da mulher abandonada ou vingativa. Herivelto Martins, em “Caminhemos”, declara: "Não, eu não posso lembrar que te amei/não, eu preciso esquecer que sofri.” Uma sensação de incompletude domina a atmosfera dramática expressa pelos cantores nos sambas-canções e boleros, um “eu interior” que clama pelo encontro com o outro, mas que subsiste na falta contínua. O traçado melódico "vertical” comum às canções passionais aparece também em “Mentiras”, música cuja primeira parte concentra-se na região médiagrave e a segunda na média-aguda. Calcanhotto, nesta canção, explicita sua releitura do ideário sentimental em versão contemporânea:

Nada ficou no lugar

Eu quero quebrar essas xícaras

Eu vou enganar o diabo

Eu quero acordar sua família

Eu vou escrever no seu muro

E violentar o seu gosto

Eu quero roubar no seu jogo

Eu já arranhei os seus discos

Que é pra ver se você volta

Que é pra ver se você vem

Que é pra ver se você olha pra mim

Nada ficou no lugar

Eu quero entregar suas mentiras

Eu vou invadir sua aula

Queria falar sua língua

Eu vou publicar seus segredos

Eu vou mergulhar sua guia 
Eu vou derramar nos seus planos

O resto da minha alegria (In: CALCANHOTTO, 1992)

"Mentiras” retoma o ideário da tradição "ultra romântica” da música popular brasileira, marcado pelo romantismo exacerbado à maneira das canções de Lupicínio Rodrigues e Maysa, cujo ser apaixonado explicita derramamentos e sofreguidão amorosa. Calcanhotto interpreta a canção à sua maneira cool, que contrasta com a substância de cunho dramático dos versos, e relê o legado de tradição romântica da canção “dó de peito” que envolveu o período das grandes vozes brasileiras, como Dalva de Oliveira, Ângela Maria e Cauby Peixoto. Os versos acentuam um amor desgovernado, insano, em que o ser enamorado é capaz de destruir a própria vida e a do ser amado em virtude da desilusão amorosa. A manifestação do ódio exacerbado e da vingança ressalta em versos como

Eu já arranhei os seus discos

Eu quero entregar suas mentiras

Eu vou publicar seus segredos (In: CALCANHOTTO, 1992)

Esta canção remete ao imaginário das músicas sentimentais que tematizam amores passionais como "Vingança”, de Lupicínio Rodrigues:

Só vingança, vingança, vingança

Aos santos clamar

Ela há de rolar como as pedras

Que rolam na estrada

Sem ter nunca um caminho seu

Pra poder descansar (http://www.youtube.com/watch?v=ZXFginzWtFc)

A interpretação dos versos regados de paixão e desequilíbrio emocional de uma maneira “equilibrada” e comedida faz despontar certo ar de ironia que deixa evidente o ponto dissonante no qual Calcanhotto transita. Nesta canção, sua voz imprime certo tom melancólico que irá permear outras gravações, constituindo uma característica marcante em suas interpretações. Nota-se esse traço melancólico na forma como ela conduz o colorido e a finalização das frases: a voz demonstra não ultrapassar certo parâmetro de linearidade que faz com que, ao ouvinte, de certa maneira, soe até enfadonho, repetitivo. Em “Mentiras”, o arranjo de violões e cordas cria uma base que valoriza o refrão : "Que é pra ver se você volta/Que é pra ver se você vem/Que é pra ver se você olha pra mim”. A 
atmosfera romântica é sugerida mais pela música que pelo entoar da voz da cantora, que expressa pouca exaltação sentimental.

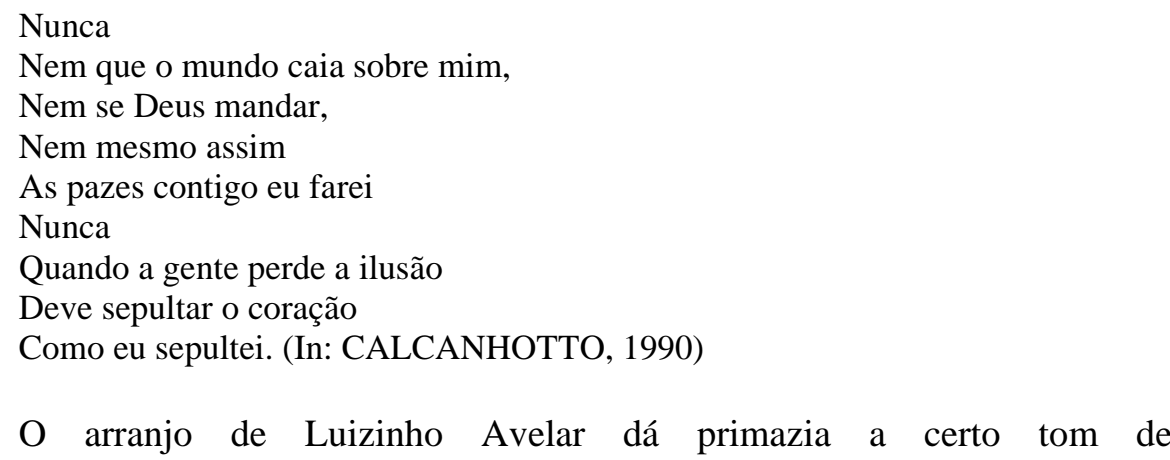
monumentalidade com o contrabaixo de Nico Assunção, guitarra de Celso Fonseca, um naipe de oito violinos, quatro violas, cellos de Kundert e Jacques Morelembaum, além do teclado de Luizinho. É enfática a questão da monumentalidade evidenciada no arranjo de "Nunca", pois é uma das características que mais sofrerá transformações no decorrer da evolução da carreira da artista. Esta gravação faz parte do primeiro disco de Calcanhotto, cuja estética é excêntrica em relação aos trabalhos que o sucedem. "Enguiço", disco inaugural da artista, lançado em 1990, é uma obra com certa indefinição de estilo que transparece no repertório eclético que vai de João Donato a Eduardo Dusek. As interpretações se sobressaem pelo tom hiperbólico e expressionista, revelando o descompasso da transposição de uma estética musical performática para a limitação espacial do disco, ou seja, a passagem de um procedimento que fazia estritamente para o palco para o estúdio. Antes de começar a gravar, Calcanhotto estava fazendo apresentações com forte apelo performático, nos quais o humor escancarado era uma das linhas condutoras. Os espetáculos estrelados por ela se voltavam essencialmente para a representação, para a teatralidade com letras de canções a serviço da crítica irônica.

Em "Nunca", a cantora dialoga com o legado da tradição do canto exacerbado. Não reproduz uma canção de cunho efetivamente expressionista, mas também não opta por uma leitura mais linear e seca, como faz em "Mentiras”. A voz de Calcanhotto ratifica um percurso pleno de modulações, o arranjo que favorece a emissão do canto em camadas ondulatórias cria uma base que a princípio introduz a canção num tom médio, com a voz passeando por notas mais graves. A música prossegue num movimento ascensional em que a explosão de 
notas agudas entoadas pela cantora reproduz a filiação ao ideário romântico. Essa modulação ascensional alcança o ápice no momento mais dramático da canção, quando sua voz soa bastante aguda e com uma sonoridade infantilizada nos seguintes versos:

\author{
Saudade \\ Diga a esse moço, por favor \\ Como foi sincero o meu amor \\ Quanto eu o adorei tempos atrás \\ Saudade \\ Não se esqueça também de dizer \\ Quem é você quem me faz adormecer \\ Pra que eu viva em paz. (Idem).
}

No refrão, Calcanhotto elabora uma considerável elevação tonal em que o efeito expressivo ganha maior destaque, pois as notas agudas são resultantes de uma pressão mais intensa sobre as cordas vocais. A cantora passa da região média-grave da primeira parte para a região média-aguda na segunda, em que o efeito tensificador produzido pela elevação tonal cria uma atmosfera mais dramática na música. Este recurso pode ser constatado em outras canções de caráter sentimental do cancioneiro nacional, como "Travessia”, cujo movimento ascensional é muito evidente: "Solto a voz nas estradas/ Já não quero parar/ Meu caminho é de pedra/ Já não posso sonhar”. Nesta canção, a impressão do tom que se eleva se assemelha àquela que produz um corpo lançado para cima no espaço. A atividade vibratória torna-se mais rápida na media em que a nota se eleva, formando o impacto sonoro.

Mesmo que os versos da canção retratem uma história de desencanto em que a figura feminina não clama pelo amor de seu ex-parceiro, não deixa de ser a manifestação de um derramamento. Nota-se que, no transcorrer do tempo, tem-se aberto mais espaço para outros timbres de voz que se opõem ao paradigma da voz aguda. Afloram, na atualidade, vozes mais graves, não somente as agudas que brilham na tradição lírica e também na tradição romântica à moda das cantoras do rádio. Felipe Abreu argumenta:

Hoje, porém, é justo dizer que o papel da mulher transformou-se. Passou a ter voz ativa social, e à medida que passamos a escutar-lhes as palavras, sua tessitura foi baixando para regiões próximas à da fala (ou vice-versa?). Aplaudimos vozes graves que jamais teriam vez no canto clássico, de Maria Bethânia a Cássia Eller, de Bessie Smith a Cesária Évora. (MATOS; MEDEIROS;TRAVASSOS, 2001, p.110) 
As tessituras femininas do canto se aproximam das masculinas e isso é resultante não somente de uma mudança na concepção estética; é decorrência também das transformações ocorridas nos papéis sociais masculinos e femininos. Abreu cita apenas algumas cantoras entre o repertório nacional (no samba, pop, rock ou demais gêneros) cujas vozes de registro grave se destacam consideravelmente.

Torna-se interessante frisar, que na análise do desempenho vocal de Calcanhotto, fizemos quase que absolutamente uma supressão dos seus movimentos corporais e centralizamos nosso foco nos elementos do canto respiração, timbre, emissão de notas, entre outros. Entretanto, devemos levar em conta que a voz do cantor não se encontra dissociada do corpo, integrante que é de todo o movimento produzido com olhos, cabeça, braços, ombros e pernas. Principalmente quando o cantor se encontra num palco, tudo o que o reveste constitui parte integrante na composição do sentido de sua performance. Figurino, cenários, luzes e demais elementos, juntamente com o artista, resultam na complexidade de uma performance. Pretender uma avaliação de caráter meticuloso do canto de Calcanhotto, centralizada essencialmente no aparelho fonador, sem recorrer a análise de sua performance, constitui um reducionismo. O termo performance tem sido usado comumente como sinônimo de interpretação, execução e apresentação. A performance engloba elementos formais de diversas poéticas da oralidade, como canto, narração de histórias, entre outros que se referem ao emissor e ao receptor da mensagem. Sobretudo os gestos do artista provocam um considerável impacto na transmissão e recepção da performance, pois eles acentuam, descrevem, completam e até mesmo contradizem o conteúdo do discurso explícito na letra de uma canção. Numa performance musical o papel dos gestos é de considerável relevância; o cantor pode criar seus gestos de acordo com as sugestões implícitas na música que interpreta e, em sua gesticulação, deixar impressa sua marca. Excessiva, equilibrada ou comedida, a gesticulação de um cantor é de suma importância no desenvolvimento de sua performance, pois é por meio dela associada à voz que ele poderá imprimir sua marca única. Lembremos, por exemplo, o quanto foi impactante na época a famosa "natação" de Elis Regina, em que a cantora girava freneticamente os braços na interpretação da canção "Arrastão". Sob as orientações do coreógrafo Lennie Dale, ela explorou os movimentos dos braços de 
uma maneira que chegou a soar até excessiva. Augusto de Campos, em "O balanço da bossa e outras bossas” (1993), argumenta sobre a performance exagerada da cantora na época em que ela apresentava o programa "O fino da Bossa”, ao lado do cantor Jair Rodrigues:

[...] Elis foi sendo levada a uma exageração do estilo interpretativo que criara. Seus gestos foram se tornando cada vez mais hieráticos. Os ritos faciais foram introduzidos com frequência sempre mais acentuada. A gesticulação, de expressiva, passou a ser francamente expressionista [...] Ao interpretar Zambi, a cantora parece entrar em transe. (CAMPOS, 1968, p.55)

A expressão musical de Calcanhotto se estabelece por um contínuo jogo performático de interação da voz com a movimentação do corpo. Mesmo em várias de suas apresentações de caráter minimalista, com acompanhamento apenas de seu violão, sentada, vigora um jogo performático rico em movimentos e sugestões. Cada detalhe do olhar, as inflexões de cabeça, braços e pernas compõem milimetricamente a performance de Calcanhotto. Noemi Jaffe analisa:

Assim, o que se pode afirmar é que há, nas letras, no modo de cantar e na presença cênica de Adriana Calcanhotto, um efeito de construção, e mais, de fingimento. Mas fingimento no sentido etimológico do termo: fingère é modelar na argila, dar forma a uma substância plástica, esculpir, dar feição, afeiçoar; ou reproduzir os traços de algo, representar; e, por extensão, imaginar, fingir, inventar. (Nestrowski, 2007, p.14)

Como reflete Noemi Jaffe, o "fingimento" que desponta da criação de Calcanhotto faz parte de sua estratégia criativa a qual se realiza por meio de elaborações construtivas que valorizam mais o sugestivo que o explícito, performances atravessadas por insinuações em que muitas vezes a ironia é o fio condutor. Calcanhotto explicita performances ricas em movimento e inventividade principalmente quando se apossa de Partimpim, sua criação heteronímica, que, em cena, abre espaço para o lúdico, auxiliada por cenários, figurinos e músicos, ao representar uma personagem dotada de uma pluralidade de habilidades.

“Dona de castelo”, de Jards Macalé e Waly Salomão, é uma composição de destacável lirismo que também se filia à tradição das canções sentimentais. Com a presença do duo voz e piano ao centro, e cordas e contrabaixo ao fundo, a música funde delicadeza, exasperação e precisão numa interpretação emotiva, mas que não extrapola o limite de comedimento imposto por Calcanhotto. A inteiração 
voz e piano é absoluta, não há descompasso entre a levada do piano e a voz da cantora, ambos unos e complementares. Nesta interpretação, é evidente a afinação da cantora e sua extensão vocal que suplanta o aparente nível limitado manifesto nas músicas em que ela dá primazia a uma leitura mais cool e linear. A voz de Calcanhotto ressalta a clareza e precisão na emissão das notas, valorizando com intensidade o vigor dos versos de Waly Salomão que trazem a marca de sua visceralidade.

Waly Salomão aparece com frequência nos trabalhos de Calcanhotto. No decorrer de sua carreira, ela grava outras composições do artista, como "Pista de dança” e "Teu nome mais secreto". Introduz música no poema aparentemente anti-musical "A fábrica do poema” e elabora uma leitura do poema "Remix século XX”, com fundo musical construído pela batida de seu pé direito sobre o chão.

As palavras de Waly Salomão se casam em total harmonia com a música de Macalé, e essa sintonia é um dos fatores contribuintes para o desempenho do cantor, que, um bom material diante de si é capaz de explorar seus próprios recursos vocais com segurança e até ousadia. Um exemplo que elucida a sabedoria em unir a grande potencialidade vocal à qualidade do repertório é o da cantora Elis Regina, a qual, ao longo de sua carreira, cercou-se dos melhores compositores de sua época e também dos consagrados que ultrapassam gerações. Chico Buarque, Caetano Veloso, Gilberto Gil, Tom Jobim, Nelson Cavaquinho, Joyce, Fátima Guedes, Aldir Blanc, João Bosco, Sueli Costa, Cacaso, entre outros, estiveram entre as gravações de Elis Regina. Ela escolhia canções favoráveis ao seu timbre e extensão vocal cujas letras eram condizentes com suas inquietações existenciais e políticas. Calcanhotto, ao eleger determinados compositores e letristas, procura também acentuar qualidades próprias que se afinam com os pressupostos dos artistas escolhidos. O caráter poético inerente à criação de Waly Salomão se harmoniza com o canto de Calcanhotto, que objetiva deixar em destaque o lirismo de sua interpretação. A cantora mostra com frequência um tratamento cuidadoso e depurado da palavra, em que, mais do que propriamente cantar, ambiciona cunhar o substancial lírico da canção. $\mathrm{O}$ ponto alto da interpretação de Calcanhotto em "Dona de castelo" ocorre no momento em que sua voz se eleva simbioticamente com o piano num encontro entre som e palavra: 
E quando eu saltar de banda

E quando eu saltar de lado

Vou desabar seu castelo de cartas marcadas

E tramas variadas

Sim

Seu castelo de baralho vai se desmanchar

Desmantelado

Decifrado

Sobre o borralho da sarjeta

Chegou o inverno. (In: CALCANHOTTO, 1999)

"Vambora” dá prosseguimento à linhagem romântica. Calcanhotto, ao elaborar em versos o tema da solidão amorosa, utiliza-se de referências literárias como as obras de Ferreira Gullar (“Dentro da noite veloz”) e de Manuel Bandeira (“Na cinza das horas”). O procedimento intertextual efetuado pela compositora dá um redimensionamento à sugestão lírica dos poetas:

Ainda tem o seu perfume pela casa

Ainda tem você na sala

Porque meu coração dispara

Quando tem o seu cheiro

Dentro de um livro

"Dentro da noite veloz"

“Na cinza das horas”. (In: CALCANHOTTO, 1999)

Calcanhotto gravou duas versões para a canção, primeiramente uma em estúdio e depois uma ao vivo no CD “Público”. A gravação em estúdio é realizada com uma base composta pelo violão da cantora, baixo acústico de Jorge Helder, programação, teclados e piano de Sacha Amback, e ganzá, caxixi, triângulo e vassourinha de Marcelo Costa. A interpretação da cantora é conduzida de maneira cool, com suavidade, apresentando assim a influência do legado bossanovista que traz a primazia de um canto sem arroubos e destituído de excessos, como explicita a estética joãogilbertiana.

João Gilberto introduziu a sofisticação através de um canto cool, macio, em que a voz se integra plenamente ao corpo da canção. O canto persegue obsessivamente a precisão: o acorde perfeito, a nota exata, a sílaba certa. A "batida diferente" de seu violão explora acordes dissonantes e melodias cheias de lirismo. Com a voz que se coloca em movimentos alternantes em relação ao violão, o artista expande a idéia da contradição sem conflitos, constituindo uma síntese polirrítmica perfeitamente integrada. João Gilberto, em depoimento à revista “o cruzeiro”, esclarece seu pensamento musical: 
Acho que os cantores devem sentir a música como estética, senti-la em termos de poesia e naturalidade. Quem canta deveria ser como quem reza: o essencial é a sensibilidade. Música é som. E som é voz, instrumento. O cantor terá, por isso, necessidade de saber quando e como deve alongar um agudo, um grave, de modo a transmitir com perfeição a mensagem emocional. (CAMPOS, 2003, p.36)

Na gravação de "Vambora”, em estúdio, o desempenho da voz de Calcanhotto ilustra a preocupação evidenciada por João Gilberto, porquanto a cantora canta com uma projeção de voz suave, procurando dar ênfase ao substrato poético. Nesta música não há manifestações significativas de aclives e declives que comporiam um quadro sonoro ondulante e de feição mais irregular; a voz comanda um trajeto mais linear, porém não melancólico. Calcanhotto se aproxima do “canto falado” de João Gilberto ao mostrar uma preocupação permanente com o estatuto da palavra. Segundo a artista:

Lembro-me de que quando comecei a minha carreira de música, pra mim não era pra ser uma carreira de música, na verdade era uma coisa mais ligada à palavra (apud MATOS; MEDEIROS; TRAVASSOS; 2008, p.45)

O registro ao vivo se diferencia da gravação em estúdio, pois se efetua por meio de uma economia de recursos. A artista se apropria apenas de seu violão, o que ocasiona um enxugamento ainda mais notável. Nesta interpretação devem-se levar em conta dois aspectos, quais sejam, a participação ativa do público e as peculiaridades que envolvem a atmosfera de uma gravação ao vivo. A interpretação da artista é vigorosa e mais expansiva em relação à do estúdio, a voz explora sutis modulações, evidenciando a interação artista/plateia. A participação do público altera a manifestação emotiva da cantora; há uma interação real que suplanta o clima comumente asséptico do estúdio. A preocupação com a exatidão não se torna possível no acontecimento ao vivo, em que vale todo o conjunto da performance que envolve não somente o desempenho da voz, mas de todo o corpo. A performance de feição minimalista da artista mostra harmonias compostas por sequências simples de acordes que dão sustentação e sentido ao seu canto cool.

Conforme Heloísa Valente, a voz do cantor não ecoa num vazio, sobretudo quando recebe a resposta imediata do espectador-ouvinte, como ocorre comumente numa apresentação ao vivo, na qual o artista não dialoga apenas com a sua voz, mas seu corpo inteiro interage por meio dos gestos, olhares e movimentos que constroem a força da performance: 
Ao lançar mão desses recursos, o cantor/ator/contador estabelece, na verdade, uma situação comunicativa que põe em ação interpretação, texto e ouvinte, o que quer dizer, o emissor necessita da resposta do receptor, ou seja, o ouvinte exerce função ativa que é indispensável na performance. Isto porque o ouvinte recria, de acordo com seu repertório particular, o universo significativo que lhe é transmitido pelo executante. (VALENTE, 1990, p.120)

Outra canção da vertente romântica que também se apresenta nas modalidades estúdio e ao vivo é “Mais feliz”, de Dé, Bebel Gilberto e Cazuza. Os versos explicitam certa coloquialidade que os distinguem do tom excessivo das composições amorosas do período pré-Bossa, como se verifica em "Nunca”, cujas palavras ecoam lamúrias e maldizeres. "Mais feliz" descreve uma história de amor vivenciada nos tempos pós- modernos, marcados pela fluidez e fugacidade, em que, mesmo que ocorra o desejo de continuidade de uma relação amorosa, dignifica-se seu caráter transitório:

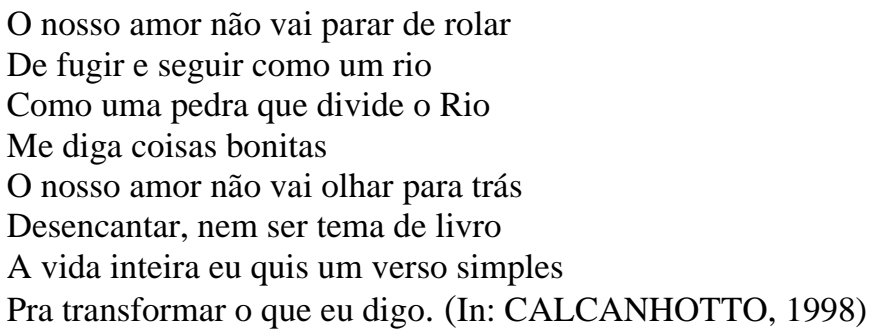

O registro em estúdio de "Mais feliz” é composto por uma levada que vai de encontro à proposta das releituras que se tem feito com standards da música nacional e internacional: mantém-se a voz do cantor e elimina-se a base original, substituindo-a por uma nova, que privilegia os recursos eletrônicos. Nesta canção a base é construída por meio da mistura de elementos sonoros em que o eletrônico predomina: a voz de Calcanhotto simultaneamente se impõe e quase se mistura com essa base pela ausência de uma marca interpretativa. A voz não apresenta consideráveis movimentos ascendentes ou descendentes; segue mais linear e afinada, sem nenhum virtuosismo, assumindo uma performance adequada ao ritmo imposto pela base que faz sobressair o trompete solo de Paulinho Trompete. Há que se frisar que, mesmo nas leituras mais "lineares” de Calcanhotto, subsiste um desenho sonoro ondulante que traz a pulsação vibratória da interpretação, pois, conforme Wisnik, 
Toda música “está cheia de inferno e céu”, pulsos estáveis e instáveis, ressonâncias e defasagens, curvas e quinas. De modo geral, o som é um feixe de ondas, um complexo de ondas, uma imbricação de pulsos desiguais, em atrito relativo. A onda sonora é complexa, e se compõe de frequências que se superpõem e se interferem. Essa complexidade é antes de mais nada a do som concreto, o som real, que é sempre, em alguma medida, impuro. (WISNIK, 1989, p.21)

A atuação da voz de Calcanhotto, que marca agudas intervenções em outras gravações da linhagem sentimental, como "Dona de castelo" e "Nunca", neste caso é revestida de uma carga de dramaticidade menor, pois ela objetiva modular seu canto para deixar em evidência a poeticidade dos versos e não acentuar nenhuma inflexão paródica ou desconstrutiva.

A gravação ao vivo de "Mais feliz" faz parte do CD "Público" e se realiza com a tríade violão/voz/plateia. A exemplo de "Vambora” (ao vivo), "Mais feliz" também demonstra o impacto da interação da artista com a platéia: acompanhada unicamente por seu violão, ela deixa seu canto ecoar mais alto e expansivo pontuando a melodia que se compõe de maneira simples, com poucos acordes. É uma voz sem excessos e estridência, mas que traz colorido e pujança interpretativa. O amor é cantado com leveza e descontração e o timbre caracteristicamente mais agudo da cantora é modulado numa tonalidade média, sem causar nenhum resultado dissonante.

“Três,” de Marina Lima e Antônio Cícero, é mais uma da safra de canções sentimentais e amorosas. Esta traz a tematização do relacionamento amoroso no mundo contemporâneo assinalado por perdas e desencontros. Nesse contexto, a transitoriedade e fluidez se fazem presentes numa ausência de concretude. O mundo pós-moderno baliza seu estado de contínuas dissoluções, que, na acepção de Zigmund Bauman (BAUMAN: 2001), pode ser sintetizado em uma palavra: líquido. Os indivíduos vivem sob o predomínio da inconstância, da escassez de todos os valores, da fugacidade, do efêmero, da rapidez sem propósitos, do individualismo, do medo e da solidão. A letra de Antônio Cícero expõe o drama contemporâneo:

Dois

Se você quer amar

Não basta um só amor

Não sei como explicar

Um só sempre é demais

Pra seres como nós 
Sujeitos a jogar

As fichas todas de uma vez

Três

Eu quero tudo o que há

O mundo e seu amor

Não quero ter que optar

Quero poder partir

Quero poder ficar

Poder extasiar

Sem nexo e em qualquer lugar

Com seu sexo junto ao mar (In: CALCANHOTTO, 2008)

A voz de Calcanhotto apresenta um nítido amadurecimento em "Três", haja vista que esta gravação se efetuou em 2007, correspondendo ao seu sétimo disco de carreira. Nota-se que ela está cantando com mais segurança, pois aprendeu a aproveitar com mais sabedoria seus recursos técnicos, e, neste caso, o domínio da respiração constituiu-se num fator de extrema relevância. O controle do diafragma, responsável pela sustentação e prolongamento das notas, é realizado com mais domínio e o equilíbrio entre médios e agudos ocasionou um efeito vocal límpido. O aprimoramento das técnicas respiratórias contribuiu também para a melhora de sua diç̧ão: os discos iniciais revelavam uma dicção menos precisa, não se ouvia com absoluta clareza todas as palavras de uma canção cantada por Calcanhotto, era usual uma sílaba final ser suprimida ou um "r" retroflexo de seu legado gaúcho soar excessivo. Dicção absolutamente correta mas "mecânica” não é o propósito de uma artista como Calcanhotto. Ela apenas aparou as arestas, permitindo que sua voz ganhasse em emissão, extensão e colorido. Em cada faixa de "Maré" nota-se a evolução de seu canto. Destaca-se o colorido do timbre em cada modulação, o que ocasiona um efeito estético superior. A desenvoltura do canto da artista é resultante da experiência adquirida ao longo de seu percurso artístico e também das aulas administradas pelo preparador vocal Felipe Abreu:

Ele faz todo um trabalho técnico, sobre a forma de cantar; porém, mais do que isso, é um colaborador em outros níveis, um parceiro no sentido de entender o que eu quero fazer, o que eu estou dizendo. Eu chego pra ele às vezes muito enrolada com umas questões que as canções estão me propondo, que os poemas estão colocando [...] (In: MATOS; MEDEIROS; TRAVASSOS; 2008, p.44)

Uma das questões interessantes a ser mencionada é o fato de que é comum a resistência por parte de cantores em receber instruções vocais. Muitos temem que o estudo possa levar à alteração da espontaneidade da voz, ou seja, à perda de 
sua identidade vocal. Alguns vocalizes e exercícios vocais elementares ao aprimoramento da qualidade vocal são extraídos do repertório lírico, e isto às vezes faz com que o cantor receie adquirir vibratos e impostações que não cabem ao seu estilo. Conforme argumenta Felipe Abreu:

Acho que é muito comum um artista como a Adriana, já plenamente estabelecido e consagrado, ter medo de fazer aulas de canto. Tem medo porque acha que a voz dele vai mudar, que o professor vai querer que ele faça uma Tosca. É uma coisa que realmente passa pela cabeça das pessoas, que o trabalho vai tirar sua identidade vocal; mas justamente o que se tenta com a técnica é que ela deixe a expressão da identidade se manifestar. Então no caso de uma pessoa como a Adriana, já consagrada, o trabalho é basicamente tirar o esforço, as tensões, as contrições, permitir que ela faça o trabalho sem se cansar, que consiga fazer shows, viajar, às vezes duas sessões de show por dia. (ABREU apud MATOS; MEDEIROS; TRAVASSOS, 2008, p.49)

Presume-se que Calcanhotto fez um trabalho de ajuste de seu próprio canto e de domínio de suas potencialidades vocais, o que não acarretou nenhuma descaracterização em sua performance vocal que resultasse na perda de seu estilo interpretativo. Ela aprendeu a adequar melhor seus recursos, escolhendo tons mais favoráveis à sua amplitude de voz. Entende-se por tons favoráveis aqueles que não sobrecarregam as cordas vocais, que não exigem um esforço que exceda a capacidade extensiva do cantor. Tons inadequados à extensão vocal podem ocasionar uma série de lesões que vão além do efeito estético; podem provocar nódulos irreversíveis as cordas vocais. Calcanhotto mostra-se à vontade nas tonalidades em que canta. Sua voz flui sem esforços como se no fundo não existisse um trabalho técnico por trás.

Certamente o trabalho técnico não é alcançar mais uma quinta para cima ou ter mais vinte decibéis. É simplesmente permitir que esse preparo que ela tenha seja natural e não a impeça de fazer os trabalhos que ela tem que fazer sem perigo de ter problemas vocais. (Ibidem).

Em “Três”, a voz acompanha os movimentos da música com total equilíbrio. A letra de Antonio Cícero aponta fechamentos e aberturas que se definem em cada estrofe: "Um/Foi grande o meu amor/Dois/Se você quer amar/Três/Eu quero tudo que há”. Calcanhotto explora a sonoridade das vogais abertas, valorizando as terminações das palavras com as sílabas em “a”. O canto é mais aberto sem, no entanto, esbarrar em qualquer filigrana de excesso, pois precisão é a ordem que comanda a expressividade dessa artista. 
A concentração mais precisa no canto, resultado sobretudo do nível de aprimoramento alcançado pela artista ao longo de sua carreira, é destacada na entrevista de divulgação do álbum "Maré", realizada no programa "Jô onze e meia”. Calcanhotto, motivada pelo comentário do entrevistador ("No teu caso específico é impressionante esse salto que a cada vez a tua voz e a tua interpretação dão”), define como foi se dando, no decorrer do tempo, uma lapidação no seu modo de cantar:

É porque eu tenho mais prazer de cantar hoje em dia, eu gostava do palco, eu no início fazia performance, fazia essas coisas, quebrava instrumento. Era muito ligado a teatro o que eu fazia e eu fui me concentrando mais no canto porque eu fui gostando mais de cantar, hoje em dia eu tenho muito prazer de cantar. No primeiro disco que eu fiz eu não pensava em disco, pensava em palco, tem certas ironias que não passam no disco. Coisas que são de palco, não passam no disco, não passam na TV, esse tipo de coisa que eu fui aprendendo no veículo. Uma linguagem, uma maneira. (http://www.youtube.com/watch?v=mryearLwfA0\&feature=endscreen\&NR=1)

“Se tudo pode acontecer”, de Arnaldo Antunes, Paulo Tatit, Alice Ruiz e João Bandeira, é uma canção que coloca o amor em destaque num tom de absoluta leveza. Não é o amor exasperado ou permeado de rancores e lamúrias, mas um amor que pode acontecer como um presente do acaso, um brinde da natureza:

Pode alguém aparecer

E acontecer de ser você

Um cometa vir ao chão

Um relâmpago na escuridão

E a gente caminhando

De mão dada

De qualquer maneira

Eu quero que esse momento

Dure a vida inteira

E além da vida

Ainda de manhã

No outro dia

Se for eu e você

Se assim acontecer (In: CALCANHOTTO, 2002)

O arranjo minimalista é composto pelo violão, contrabaixo de Dé Palmeira, piano de Daniel Jobim, bateria de brinquedo de Domenico e trompete e cellos de Moreno Veloso. O piano de Daniel é econômico conforme o legado jobiniano e os demais instrumentos também são conduzidos numa levada suave que dá suporte ao lirismo dos versos. A voz de Calcanhotto é suave e comedida, 
como se ela cantasse solta, distante de microfones e outros alicerces do ambiente de estúdio. Em "Se tudo pode acontecer", a cantora procura deixar que transpareça apenas o substrato poético da canção em sua essência pura e a voz é seca no que tange a redução dos excessos, econômica na medida do piano de Daniel Jobim. O efeito cool alcançado nesta canção é um dos objetivos fundamentais da criação musical de Calcanhotto e neste sentido sua proposta estética- musical dialoga com o legado bossanovista. Por meio da audição de suas interpretações verifica-se que esta artista privilegia uma expressão musical destituída de excessos, em que a força da composição resida em sua essencialidade, em seu poder de compactação, redução, sem qualquer artifício que faça a canção se desprender de sua poesia intrínseca.

As harmonias executadas no violão por Calcanhotto revelam sua opção por uma condução minimalista. Ela usa sequências simples e curtas de acordes, com ausência de improvisos que ultrapassem o cerne da canção. A intenção da artista não é acentuar nenhum caráter virtuoso em suas execuções instrumentais. Seu desempenho com o violão objetiva apenas elaborar uma base sonora mínima, essencial, que sirva como apoio sonoro para o despontar de seu canto. Seguindo analiticamente o percurso traçado pela artista, podemos dizer que ela elege uma estética do "menos”, em que seu maior desafio consiste na depuração sonora, que isenta a criação de camadas excessivas. Em entrevista, Calcanhotto diz não gostar

[...] do minimalismo estéril, estetizado, clean, a priori. Minha coisa é com a essencialização e tenho a impressão de que parto do excesso transbordante para 0 prazer e o divertimento de podá-lo. (In: FERRAZ, 2008)

Outra vertente do cancioneiro nacional explorada por Calcanhotto é a que diz respeito ao repertório da Jovem Guarda. A expressão "Jovem Guarda” se refere ao programa televisivo exibido pela Rede Record entre os anos de 1965 e 1968, apresentado por Roberto Carlos, Erasmo Carlos e Wanderléia. Sob a influência do rock and Roll, de Elvis Presley, Beatles e outros artistas britânicos e norte americanos, os três jovens formaram uma linguagem própria denominada Iê-iê-iê. As influências da Jovem Guarda no cotidiano dos jovens brasileiros desse período demonstram o forte poder exercido pela mídia televisiva. A propagação de estilos de vida que envolvem maneiras de vestir, pensar e agir, difundidos por meio da indústria cultural, adquire força a partir da introdução e expansão da 
televisão, que trouxe para perto do público a imagem de seus ídolos. Tudo o que envolvia o figurino e os modos de comportamento dos artistas da Jovem Guarda, de certa maneira, exercia certo poder sobre a juventude da época.

Por serem destituídas de um caráter crítico, mas, ao contrário, voltam-se para uma expressividade descompromissada e até “alienada”, as músicas da Jovem Guarda são consideradas, sob uma perspectiva crítica mais acirrada, apenas como uma espécie de subproduto da indústria cultural. A explosão do Iê-iê-iê suscitou na época polêmicos debates sobre a questão dos "malefícios" causados à cultura brasileira pela entrada dessa modalidade de arte de massa. Ferreira Gullar num debate publicado originalmente na Revista Civilização Brasileira argumenta:

O iê-iê-iê é um fenômeno da internacionalização da cultura. Ninguém pode deter que essas formas de música internacionais invadam os países do mundo e muito menos os países subdesenvolvidos. Impedir que uma música como o iê-iê-iê penetre no Brasil é impossível - a menos que se fechasse o país, cercasse-o, desligasse-o do mundo, o que impediria também a entrada de coisas muito mais importantes e necessárias para o desenvolvimento da civilização brasileira. [...] Mas qual é a maneira de impedir o malefício que a cultura de massa internacional traz para o desenvolvimento da cultura brasileira? O meu ponto de vista é que só há um modo de lutar contra isso. Não deve ser o de fechar o país mas de ter uma atitude crítica e de combate no mesmo nível que isso se coloca - quer dizer: combate cultural. (COHN: 2008, p.30)

Gullar propunha o combate cultural que se realizaria mediante a ação de uma postura crítica. Na visão do poeta, tornava-se fundamental a tomada de consciência das pessoas sobre aquilo que estavam recebendo. Contra um recepção passiva e acrítica, ele sugeria o debate, que seria uma das formas de luta contra a alienação: "O debate as influencia, chama a atenção dessas pessoas para uma série de fenômenos” (COHN: 2008, p.30). Ele era consciente da impossibilidade da execução de uma postura rígida, que no caso seria uma manifestação "ingênua" perante a força exercida pelos novos movimentos que traziam para o Brasil muito da informação internacional.

A denominada "música brega", designada por um tipo de canção romântica de forte apelo sentimental e composta em geral por sequências harmônicas pobres, descende diretamente do estilo enaltecido pela Jovem Guarda. A Jovem Guarda pode ser vista como uma espécie de vanguarda da música de massa no Brasil, que posteriormente teve seus desdobramentos na música romântica e na música sertaneja romântica, ambas qualificadas pelo senso comum 
como música "comercial”. Assim como na Bossa Nova, os intérpretes da Jovem Guarda lançavam mão de um timbre de voz suave em canções que tematizavam o amor, mas através de uma postura mais provocativa, como em "Que tudo mais vá pro inferno”, de Roberto e Erasmo Carlos.

Calcanhotto revisita a proposta musical concebida pela Jovem Guarda por meio de releituras de composições que fizeram parte do repertório do grupo. Ela traz em suas interpretações um olhar diferenciado, que faz com que as canções ganhem uma sonoridade singular, que se distingue substancialmente da concepção original. "Devolva-me”, uma releitura da cantora para a música de Renato Barros e Lilian Knapp gravada na década de sessenta, alcançou grande sucesso e tocou durante longa temporada nas rádios do país. Munida apenas de seu violão, Calcanhotto elabora uma nova versão absolutamente distinta, apropriando-se com segurança da composição alheia como se fosse dela própria. A cantora retira as marcas que porventura poderiam remeter a nova versão ao estilo brega e impõe sua assinatura rasurante. A versão inicial, conduzida pela dupla Leno e Lilian, é quadrada, o arranjo é chapado e as vozes não trazem uma valorização significativa da palavra, enquanto Calcanhotto coloca no centro a força dos versos que adquirem um novo colorido. O dedilhar do violão dá suporte a uma construção harmônica simples, elaborada por uma sequência curta de acordes, e a voz imprime um novo dinamismo as palavras, sem contudo expressar nenhum excesso, numa emoção controlada. A sutileza é a marca maior da artista nessa interpretação que sublinha sua assinatura nas pequenas intervenções vocais, ressaltando-se a interferência que ela sutilmente realiza na elevação vocal por meio dos versos:

\author{
Deixe-me sozinho \\ porque assim eu viverei em paz \\ quero que sejas bem feliz \\ junto do seu novo rapaz. (In: CALCANHOTTO, 2000)
}

A dinâmica do canto da artista evidencia o desenho melódico da canção; em certas ocasiões ela modula a voz nos agudos para revelar uma intensidade emocional. Há que se frisar que "Devolva-me” é gravada ao vivo, e, em decorrência, deixa aflorar a influência da atuação do público sobre o desempenho da cantora, que está efetuando uma performance em que a recepção ocupa lugar de destaque por meio de palmas, assovios, vozes e gritos. Nota-se neste registro 
ao vivo o instante em que a cantora faz uma pausa e logo em seguida retorna a cantar acompanhada por uma profusão de palmas. Calcanhotto declara:

Na performance ao vivo o que está em jogo é a química única daquela apresentação, daquela platéia, naquela noite, todos os cruzamentos de uma sala, de preferência cheia, com aquela noite, aquela noite de cada um, e de quem está fazendo a performance, é uma coisa que tem a ver com esse timing. Pelo menos pra mim [...] As questões da interpretação eu acho que vêm antes, são mais importantes do que as questões técnicas do canto. (In: MATOS; MEDEIROS; TRAVASSOS; 2008, p. 52)

“Caminhoneiro”, de Roberto e Erasmo Carlos, é uma releitura de Calcanhotto que explicita um caráter mais expressionista. Com uma base composta pelo arranjo e violão virtuoso de Raphael Rabello acrescidos pela percussão de Mingo, a cantora coloca em destaque sua versatilidade vocal. Rabello introduz a canção com uma levada que faz menção a Paco de Lucia, enquanto Calcanhotto inicia seu canto numa tonalidade aguda que explora uma emissão vocal aberta, expansiva. A voz da cantora comanda uma interpretação que trabalha as potencialidades do canto enriquecidas pelo arranjo criado por Rabello, que possibilita uma considerável liberdade vocal da artista. O violonista transforma uma parte da canção em baião, oferecendo a base para ela brincar com seu timbre, tonalidades e texturas, impondo um formato próprio aos versos:

Eu sei, tô correndo ao encontro dela

Coração tá disparado

Mas eu ando com cuidado

Não me arrisco na banguela

Eu sei, todo dia nessa estrada

No volante eu penso nela

Já pintei no para-choque um coração

e o nome dela (In: CALCANHOTTO, 1990)

Nesta gravação de "Caminhoneiro" o humor que desponta da interpretação de Calcanhotto intensifica ainda mais o caráter kitsch da canção, demonstrando a vertente cômica novamente como uma via de leitura rasurante elaborada pela artista . Observa-se que nesta e outras músicas da linhagem paródica, Calcanhotto revela uma conexão com a estética do humor mais escancarado.

“Por isso eu corro demais”, de Roberto Carlos, ganha uma interpretação minimalista de Calcanhotto, cujo violão destaca-se à frente ao lado da voz, enquanto as guitarras de Felipe Eyer e os efeitos sonoros de Rodrigo Lopes e Vitor Farias produzem sutis intervenções. O arranjo da gravação realizada por 
Roberto Carlos em 1967 distingue-se consideravelmente da releitura produzida por Calcanhotto: a cantora retira os excessos de sonoridades que pertenciam à gravação de Roberto deixando somente o substancial composto pela voz e violão. A emissão da voz de Calcanhotto privilegia a contenção, com um equilíbrio do princípio ao fim da canção. Ela não faz significativos movimentos ascensionais e não há nenhuma espécie de derramamento emocional, resultando numa interpretação da linhagem cool. Os versos da música são valorizados também pela performance do violão da cantora, que, ao optar por uma sequência harmônica parcimoniosa reforça a vivacidade rítmica

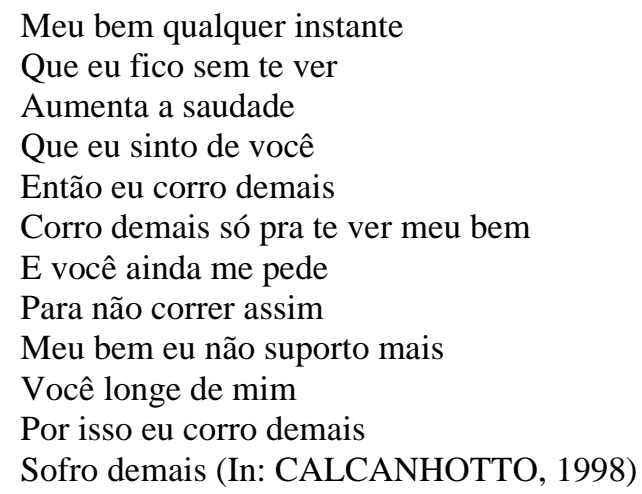

Embora a música tenha o tema amoroso como mote, a interpretação vocal de Calcanhotto é seca, deixando que fique em evidência somente a qualidade dos versos.

Outro aspecto destacável no repertório de Calcanhotto diz respeito ao diálogo que a cantora/compositora estabelece com o ideário das canções de protesto, que eclodiram no Brasil após o golpe militar e elevaram o debate em torno do engajamento e da eficácia revolucionária da palavra poética. Nesse momento os músicos "engajados" passaram a compor seguindo objetivos revolucionários que demonstravam a utopia de libertar as massas oprimidas por meio de uma consciência adquirida via sensibilidade artística. Músicos como Sérgio Ricardo, Edu Lobo, Geraldo Vandré e Carlos Lyra foram os pilares da proposta musical revolucionária. "Senhas” consiste numa espécie de música manifesto que se enquadra numa das arestas dos cinco círculos semióticos fundamentados por Diniz (2003), cujo argumento crítico é que a vertente da canção de protesto é um dos segmentos de formação do cancioneiro nacional, e o reconhecimento de seu legado histórico é importante para a fundamentação da 
análise do percurso das vozes no Brasil, que vem de uma tradição do canto empostado até chegar no formato minimalista e essencialista da Bossa Nova. A canção “Senhas” é um manifesto estético ideológico de caráter dessacralizante, em que a artista discute a questão das imposições culturais. Em entrevista Calcanhotto afirma não gostar

[...] dessa instituição do bom gosto, como se isso salvasse os trabalhos das pessoas de outro tipo de mal. O bom gosto é uma instituição falida, que serve para as pessoas se protegerem. Em arte, bom gosto é um critério que fecha. Jean Genet não era chique. Isso não interessa. (Leoni, 1995, p.232)

A música filia-se à postura iconoclasta e dessacralizante das vanguardas históricas e do modernismo que teve como representante máximo, na MPB, o movimento Tropicalista. Assim como a canção “Tropicália” consistiu num manifesto estético que explicitava a opinião desses artistas a respeito da arte, do comportamento e da identidade, a canção-manifesto de Calcanhotto permite uma leitura dialógica que revisita questões que emergiram no movimento Tropicalista. Como sugere o próprio título, trata-se de um discurso híbrido e nebuloso em que cabe ao ouvinte desvendar os mistérios e conchavos que submergem à sua estrutura, cujo caráter lúdico se sobressai por meio de um intrincado jogo de antinomias que contrapõem as esferas da aparência e da essência, do oculto e do mostrado. O recurso do disfarce, que domina uma diversidade de estéticas, é preenchido, na modernidade, pelo domínio da visualização, que adquire sua função no tradicional conceito de simulacro. Baudrillard define a cultura do simulacro pela proximidade absoluta e instantânea das coisas, pela superexposição e transparência do mundo, pela constância do obsceno.

Um dado importante a ser frisado é o fato de que há na canção um jogo realizado por meio da alternância entre a retórica da dissimulação, que sugere a presença e a simulação, que instaura a ausência. Essa alternância encaminha-nos para a seguinte indagação: como Calcanhotto de fato articula esse jogo do disfarce?

O primado da negação permeia os versos da canção “Senhas”, em que Calcanhotto questiona a institucionalização dos padrões estéticos e comportamentais:

Eu não gosto do bom gosto

Eu não gosto de bom senso 
Eu não gosto dos bons modos

Não gosto (In: CALCANHOTTO, 1992)

A artista questiona os pólos tradição/modernidade ao colocar em evidência atitudes que correspondem às duas vertentes e, como num manifesto à moda modernista, explicita o panorama estético-criativo emoldurado por uma diversidade de limitações. A estética da dissimulação é sugerida pelas palavras “conchavos" e "aparências", em que a artista trabalha polaridades dicotômicas através de um discurso que se disfarça como um simples manifesto de preferências pessoais:

Eu aguento até rigores

Eu não tenho pena dos traídos

Eu hospedo infratores e banidos

Eu respeito conveniências

Eu não ligo pra conchavos

Eu suporto aparências

Eu não gosto de maus tratos (Idem)

Uma das marcas da retórica dissimuladora se dá através da ironia e da subjetividade em que a utilização do pronome pessoal "eu” acentua as percepções e opiniões subjetivas da artista, dando um caráter intensificador ao seu manifesto revoltado, ao mesmo tempo em que possibilita uma maior legitimação do discurso.

A contínua utilização da palavra "não" visa solidificar o discurso que se pretende aparentemente transgressor e expressa também um tom de esvaziamento devido ao próprio tom enfadonho. As colocações da compositora parecem soar muitas vezes contraditórias, pois se esta canção-manifesto pretendesse realmente romper totalmente com o rigor artístico, a escritura não estaria tão ordenadamente composta, a espacialização não obedeceria à tamanha simetria e a música seria atonal, privilegiando a não previsibilidade harmônica. Essa canção, destituída de experimentalismos sonoros, retoma de certa maneira o encadeamento construtivo que pontuou as canções de protesto. A construção do desenho melódico de "Senhas" é estabelecido através de uma progressão ascensional que explode no último verso, numa espécie de catarse, como define Adélia Bezerra de Menezes: "Podemos dizer que a canção de protesto exerce na sociedade uma função catártica, pois agenda ao nível da afetividade, provoca uma liberação de emoções, um certo alívio” (MENEZES,1979, p.62). 
Calcanhotto inicia seu canto quase que em récita, pronunciando as palavras iniciais marcadas pela condução do baixo elétrico. Na evolução da performance vocal introduz-se mais massa sonora à canção à medida que a cantora divide o espaço de sua voz com outros instrumentos, como violoncelo, guitarra e bateria. O “canto fala” de Calcanhotto procura dar ênfase à força das palavras com o objetivo de criar mais impacto e veracidade a sua interpretação. Esse canto récita prossegue com sua essência seca e impositiva até a entrada do refrão, a partir do qual a cantora expande sua voz e deixa fluir uma interpretação plena de vigor em que a exteriorização do desejo se faz lei:

Eu gosto dos que têm fome

Dos que morrem de vontade

Dos que secam de desejo

Dos que ardem [...] (In: CALCANHOTTO, 1992)

No refrão que vai se repetindo até fechar a música in fade out, Calcanhotto ousa na expansão das terminações das palavras e brinca fazendo alguns vocalizes expressando a liberdade do canto. A mistura de instrumentos que vão se inserindo na canção dá suporte a sua ampliação vocal e proporciona também um caráter hibrido à canção, remetendo-a ao legado composicional dos tropicalistas que se caracterizaram pelos contrastes e misturas. Por conseguinte, a compreensão do universo da modernidade passa pelo entendimento de que todas as proclamadas inovações não deixam de ser paródias, paráfrases, releituras e reinterpretações, ou seja, aos "caretas” que se limitam a imposições puristas e pseudo absolutas só lhes resta versões inferiores, “segundos cadernos”, pois o código/senha do mundo moderno exige ousadia:

\footnotetext{
Eu aguento até os modernos

E seus segundos cadernos

Eu aguento até os caretas

E suas verdades perfeitas (idem)
}

A canção produz um discurso autoreferencial no qual a marcação do "eu” demonstra um movimento circular sobre si mesmo, num exercício de experimentação com a própria linguagem acentuada por um caráter metalinguístico, cujo discurso é preenchido pelo binômio natureza x cultura. As percepções subjetivas da artista são trabalhadas dialeticamente com a intensificação de imagens externas contrapostas a imagens subjetivas. Em sua 
postura de "voyeuse”, Calcanhotto não contempla passivamente o espetáculo do mundo que, em seu movimento de aceleração descontínua, permanece ainda arraigado a conceitos estratificados. Os valores culturais contrapostos na canção estão impossibilitados de ultrapassar a sua relatividade, justamente por constituírem um critério de julgamento humano e, por isso, não totalmente livre e destituído de sua herança histórica de imposição cultural. Calcanhotto se solidariza com os criadores que sobrevivem na contramão da cultura institucionalizada e novamente estabelece o diálogo com o ideário dos tropicalistas. Verifica-se que, em "Senhas”, a assinatura rasurante da voz de Calcanhotto se faz sobretudo pelo diálogo que a cantora elabora com o ideário das canções de protesto. Seu domínio vocal segue as prerrogativas comuns ao gênero que se destacou por uma postura vocal em que o caráter contestatório ilustrava uma voz marcada pela inquietude. 


\section{Performance}

Drummond, nos últimos versos de "Mãos dadas”, define: “O tempo é a minha matéria, o tempo presente, os homens presentes, a vida presente" (ANDRADE: 1978). Ao refletirmos sobre a criação de Adriana Calcanhotto, inevitavelmente, mesmo que nas entrelinhas, estamos questionando sua existência no universo contemporâneo, ou seja, tudo o que envolve a produção desta artista está ligada ao tempo em que vive. Contemporânea, iconoclasta, clássica, saudosista, antenada, uma série de adjetivos têm sido por nós utilizados ao longo deste estudo para tentar apreender seu mundo criativo. Artista de seu tempo, Calcanhotto produz suas obras com os olhos no presente, mas consciente da força da tradição que estrutura os pilares de sua criação, que traz na contínua revisão do passado matéria prima/viva em pleno movimento de expansão, revisão e deglutição. TS Eliot no ensaio “Tradição e talento individual”, elabora uma longa reflexão sobre a importância da consciência da tradição na obra de um artista. Conforme argumenta o escritor, o verdadeiro criador é aquele que sabe da importância que traz o legado de seus antepassados sobre a sua criação. Na acepção de Eliot a tradição não advém de uma herança adquirida por um processo natural, mas é resultado de uma conquista que requer esforço. Embora sua análise se dirija primordialmente ao universo literário, em que ele expõe seus pressupostos àqueles que desejam enveredar seriamente pelo ofício da criação literária, há uma amplitude reflexiva que se expande para a criação de qualquer espécie

Nenhum poeta, nenhum artista, tem sua significação completa sozinho. Seu significado e a apreciação que dele fazemos constituem a apreciação de sua relação com os poetas e artistas mortos. Não se pode estimá-lo em si, é preciso situá-lo, para contraste e comparação, entre os mortos. Entendo isso como um princípio de estética, não apenas histórica, mas no sentido crítico. É necessário que ele seja harmônico, coeso e não unilateral; o que acontece quando uma nova obra de arte aparece é, às vezes, o que ocorre simultaneamente com relação a todas as obras de arte que a precedem. (ELIOT, 1989, p.32) 
Como argumenta Elliot, um artista jamais poderá existir absolutamente isolado; sua obra se compõe por seu caráter individual acrescido de uma carga de informações e influências advindas da geração em que nasceu e vive, além das outras que lhe antecedem. Pensar a criação de Calcanhotto implica tentar de alguma forma situá-la em relação ao seu tempo, entender de que maneira sua performance, que abrange voz, corpo, palavras, sons e imagens está comunicando com o universo em que vive, ou seja, a contemporaneidade. Agamben, em "O que é o contemporâneo (2009)”, discute a questão da problemática que consiste na aceitação, reconhecimento e inserção do artista na atualidade. A seu ver, ser um artista contemporâneo não implica simplesmente estar inteiramente adequado as proposições e tendências de seu próprio tempo, mas estar na verdade padecendo de alguma espécie de inadequação que o faz de certa forma relativamente distanciado do tempo em que vive. O artista que apresenta dificuldade em se enquadrar ao seu tempo de existência, deixando aflorar em si um sentimento de permanente descontinuidade, atua como uma espécie de criador aguçadamente crítico, haja vista que, não se sentindo inteiramente adaptado ao momento em que vive, apresenta uma percepção mais ampla que abrange não somente os aspectos positivos.

Pertence verdadeiramente ao seu tempo, é verdadeiramente contemporâneo, aquele que não coincide perfeitamente com este, nem está adequado às suas pretensões e é, portanto, nesse sentido, inatual; mas, exatamente por isso, exatamente através desse deslocamento e desse anacronismo, ele é capaz, mais do que os outros, de perceber e apreender o seu tempo. (AGAMBEN, 2009, p.59)

Agamben não faz a defesa de um artista nostálgico que só encontra afinidade com o tempo passado e valores cristalizados, mas põe em questão a relação deste com seu próprio tempo. Conforme elucida o crítico, a contemporaneidade consiste numa relação singular com o próprio tempo que comporta simultaneamente adesão e distanciamento. Sendo assim, o artista que coincide muito plenamente com sua época, que a ela adere em todos os aspectos sem nenhuma objeção, não é de fato um contemporâneo, pois não consegue vê-la de fato. Contemporâneo é aquele que mantém o olhar fixo no seu tempo, para nele perceber não somente as luzes, mas o escuro. Essa percepção do escuro se efetua numa perspectiva relativista que equivale a "neutralizar as luzes que provem da época para descobrir as suas trevas, o seu escuro especial, que não é, no entanto, 
separável daquelas luzes” (AGAMBEN, 2009, p.63). O crítico defende que o contemporâneo acima de tudo é aquele indivíduo criador que enxerga o escuro de seu tempo e não cessa de interpretá-lo a todo momento, sendo assim mais instigado por essa obscuridade que avista do que pelas luzes que em muitos aspectos recobrem mais a superfície.

Perceber no escuro do presente essa luz que procura nos alcançar e não pode fazê-lo, isso significa ser contemporâneo. Por isso os contemporâneos são raros. E por isso ser contemporâneo é, antes de tudo, uma questão de coragem: porque significa ser capaz não apenas de manter fixo o olhar no escuro da época, mas também de perceber nesse escuro uma luz que, dirigida para nós, distancia-se infinitamente de nós. Ou ainda: ser pontual num compromisso ao qual se pode apenas faltar. (AGAMBEN, 2009, p. 65)

Ao refletirmos sobre a criação de Calcanhotto tocam-nos algumas questões que têm nos inquietado ao longo da escrita desta tese. Pensar a linguagem criativa desta artista e suas formas de expressão coloca-nos irremediavelmente diante de algumas indagações: o que propõe a artista Adriana Calcanhotto? O que faz dela uma artista contemporânea?

Calcanhotto é uma cantora que não se ocupa estritamente com o ato de compor e cantar, visto que apresenta em suas obras contínuos diálogos com outras artes em que se sobressaem a literatura e as artes plásticas. Por meio de elaborações dialógicas constantes, ela faz sua arte se destacar no universo contemporâneo pelo tratamento apurado que constrói, no qual o aspecto performático é um dos dados mais relevantes. A palavra performance tem sido muito utilizada para designar uma diversidade de produções que povoam o universo atual e por isso mesmo sugere uma série de direcionamentos que nem sempre se encontram num mesmo seguimento, ou linha de abordagem. Em seu caráter abrangente a performance se refere a um ato pelo qual se dá forma a alguma coisa ou se revela a forma de alguma coisa. Ela pode significar execução, desempenho, preenchimento, realização, atuação, acompanhamento, ação, ato, explosão, capacidade ou habilidade, uma cerimônia, um rito, um espetáculo, a execução de uma peça de música, uma representação teatral ou um feito acrobático. Marvin Carlson explicita:

Reconhecer que nossas vidas estão estruturadas de acordo com modos de comportamento repetidos e socialmente sancionados levanta a possibilidade de que qualquer atividade humana possa ser considerada performance, ou, pelo 
menos, que toda atividade é executada com uma consciência de si mesma. A diferença entre fazer e "performar", de acordo com esse modo de pensar, parece estar na estrutura do teatro versus vida real mas numa atitude - podemos fazer ações sem pensar mas, quando pensamos sobre elas, isso introduz uma consciência que lhes dá qualidade de performance. (CARLSON, 2010, p. 15)

O termo performance é bastante utilizado na arte contemporânea para designar vários tipos de intervenções artísticas nas quais o artista assume um papel ativo frente ao público, atuando muitas vezes como o próprio veículo de expressão de sua obra. Toda performance envolve uma consciência de duplicidade, através do qual a execução real de um ato é colocada em comparação com um modelo - potencial, ideal ou relembrado - dessa ação. Em geral essa comparação é realizada pelo observador da ação - o público do teatro, o professor da escola, o palestrante. O mais importante é a dupla consciência que se dá na performance: uma performance é sempre destinada a alguém, um público que reconhece e valida como performance.

O objetivo da performance é transformar o corpo em um signo, em um veículo significante, cuja unidade de trabalho se apresenta numa variedade de sentidos, sejam eles visuais, olfativos, tácteis, auditivos. O corpo é uma unidade autosuficiente e na arte da performance essa unidade é realizada como um instrumento de comunicação. O elemento erótico, inerente a toda forma de expressão corporal, torna indispensável, por parte do performer, uma consciência de si próprio para que esteja sempre apto a conduzir seus movimentos. Antes de tudo a performance é uma expressão cênica, cujo início se dá marcadamente no século XX e com o advento da modernidade. É um movimento artístico que aproxima arte e vida, resgata uma prática radical e dá vazão a uma criatividade que transmuta os elementos de expressividade. Segundo Cohen (2007), a performance se situa no limite das artes plásticas e das artes cênicas, é uma linguagem híbrida e fronteiriça que guarda características da primeira enquanto origem e da segunda enquanto finalidade. É essencialmente uma arte de intervenção, modificadora, visando causar uma transformação no público. A performance incorpora a idéia da interdisciplinariedade como caminho para uma arte total que faz uso de várias linguagens, a música se integra com a dança, ambas são suportadas por um cenário, uma iluminação, uma filmagem, uma plástica que se compõem num espetáculo total num lastro, que vai de espetáculos 
de grande espontaneidade e liberdade de execução até espetáculos altamente formalizados e deliberados.

Cohen, em sua obra "Performance como Linguagem”, um dos primeiros livros escritos sobre o tema no Brasil, explora relações nos âmbitos formal e ideológico da performance desde os processos de criação às formas de entendimento da cena e suas características como arte de contestação que, assim como o happenning, apoia-se no instante do acontecimento . O autor acentua sua percepção da performance como um acontecimento imbuído de característica ritualística, ou seja, com a valorização do tempo presente e o estabelecimento de uma comunhão com o público para a condição de testemunha do acontecimento. Cohen transcende as tradicionais noções de arte como estética contemplativa, que costuma suplantar a existência de um processo interativo entre obra e espectador. Para a performance, ritualizar implica envolver, tomar o outro como parte de um processo intersubjetivo, compartilhado, coletivo.

Cohen caracteriza a performance como um amplo campo de experimentação e pesquisa de linguagens, que incorpora elementos de várias artes.O artista a seu ver é uma espécie de livre “colador”, que se utiliza da associação anárquica, irrestrita e libertária na criação através da mixagem (mixedmedia), sem querer saber quais os processos hierárquicos que podem limitar sua escolha. Sendo assim, o artista sob o olhar de Cohen não se submete às imposições midiáticas ou a qualquer expectativa construída pelo próprio público, e sua liberdade aproxima-o de certa postura anárquica.

Nenhuma performance pode ser vista isolada de seu contexto, pois qualquer manifestação guarda forte associação com seu meio cultural. A vida é elemento de criação e recriação da performance, que em sua essência está imbuída de críticas relacionadas a acontecimentos da existência. Ao tocar de forma sutil ou até mesmo grotesca nos fatos da vida, os performers colocam em evidência muitas vezes a natureza estereotipada de nossos hábitos e ações.

O corpo consiste num elemento indispensável e fundamental na execução da performance, ele fornece as ferramentas de percepção e inteiração com o ambiente em que o artista dá vazão à extensão de sua expressividade. Principalmente quando tratamos da performance de um cantor, devemos levar em conta que seu desempenho não se limita apenas ao aparelho fonador diretamente responsável pela emissão da voz; todo o seu corpo é um campo vibratório em 
constante mutação. O corpo expressa a ambiguidade do indivíduo, tanto como sensibilidade subjetiva que experencia o mundo, quanto como objeto percebido pelo mundo. Devido ao fato de ser uma subjetividade irradiadora que constitui o centro de toda experiência, ele não pode ser entendido adequadamente como mero objeto; mesmo assim ele funciona também na experiência do ser como objeto de consciência, inclusive de sua consciência corporificada.

O papel do corpo enquanto instrumento primordial do qual é reconhecido desde muito tempo, designado por termos somáticos básicos como “órgão” e “organismo”, que derivam de “organon”, palavra grega que significa instrumento. Entretanto somente nas últimas décadas do século $\mathrm{XX}$ o corpo se tornou de fato objeto de discussão nas Ciências Humanas, nos Estudos Culturais e na Filosofia. Ao refletirmos sobre a performance de uma cantora como Calcanhotto, estamos tentando compreender como se dá em diferentes formas e contextos o desempenho de seu corpo. A expressividade de seu canto que se compactua com o movimento de todo o corpo elucida uma arte em constante autoquestionamento e transformação. O corpo é o veículo de recepção e projeção no mundo e carrega em si as memórias e histórias do indivíduo:

Meu corpo é a materialização daquilo que me é próprio, realidade vivida e que determina minha relação com o mundo. Dotado de uma significação incomparável, ele existe à imagem de meu ser: é ele que eu vivo, possuo e sou, para o melhor e para o pior. Conjunto de tecidos e de órgãos, suporte da vida psíquica, sofrendo também as pressões do social, do institucional, do jurídico, os quais, sem dúvida, pervertem nele seu impulso primeiro. Eu me esforço, menos para apreendê-lo do que para escutá-lo, no nível do texto, da percepção cotidiana, ao som dos seus apetites, de suas penas e alegrias: contração e descontração dos músculos; tensões e relaxamentos internos, sensações de vazio, de pleno, de turgescência, mas também um ardor ou sua queda, o sentimento de uma ameaça ou, ao contrário, de segurança íntima, abertura ou dobra afetiva, opacidade ou transparência, alegria ou pena provindas de uma difusa representação de si próprio. (ZUMTHOR, 1993, p. 23, 24)

Zumthor através de suas reflexões elucida sobre o quanto o corpo de um indivíduo se projeta como reflexo-resultado de suas relações com o mundo. O mundo se materializa no corpo e sendo assim não existe mundo fora de uma estrutura corpórea. É no embate entre seu corpo e o universo de vidas que o circundam que o indivíduo vivencia e exterioriza suas emoções e as torna reais. O corpo é simultaneamente suporte e veículo para a criação do artista, que se dá 
através do acionamento dos diversos movimentos compostos por gestos, sons e palavras.

Zumthor problematiza a relação entre corpo e discurso visto que trata da utilização do corpo como meio de expressão artística. O teórico aproxima a arte do caminho das necessidades humanas básicas ao retomar práticas anteriores à enunciação da voz, como o gesto. Seguindo suas prerrogativas podemos afirmar que o gesto nasce antes da voz, pois, partindo do princípio de que os povos primitivos se comunicavam por meio de grunhidos, eles concentravam nas formas gestuais informações que não eram reproduzidas pela fala. Deve-se considerar também que toda voz emana de um corpo e existe um elo muito forte que o liga ao gesto. Assim como a voz, o gesto também projeta o corpo no espaço da performance, no instante da representação. O gesto e a voz se co-relacionam e a fronteira que separa esses dois campos semióticos é muito tênue, pois, conforme Zumthor "uma atitude corporal encontra seu equivalente numa inflexão da voz, e vice-versa” (ZUMTHOR: 1993, p.244). O gesto acrescido à voz permite uma ampliação do espaço de sentido que se faz por um jogo rico de significações.

O corpo se estrutura-desestrutura entre fissuras que unem e desunem múltiplos fragmentos que compõem a sua memória. Os movimentos corporais podem trazer à tona o desejo de materializar uma gramática orgânica, esta que segundo Zumthor agrega a memória do corpo, à medida que carrega em suas entranhas uma lembrança do mundo:

[...] a existência de uma lembrança orgânica das sensações, dos movimentos internos do corpo, ritmo do sangue, das vísceras, toda essa vida impressa de uma maneira indelével em minha consciência penumbral daquilo que sou, marca de um ser a cada instante desaparecido, e, no entanto, sempre eu mesmo (ZUMTHOR, 1993, p.79).

Como afirma Zumthor, o corpo traz em si suas memórias que se depositam em cada pedaço de seu todo. Contudo, a fixação de reminiscências não faz dele exclusivamente um mero depositário passivo de vivências e sensações. O performer responsável pela condução da expressividade de seu corpo deverá se manter disponível para explorar continuamente novas possibilidades, transformar em criação artística sua riqueza imaginativa. O corpo do artista não se sobressai numa existência isolada, dissociada dos demais seres que com ele interagem, ou seja, ele se cria e recria na comunicação que estabelece entre seu espaço interno e 
as forças expressivas de um outro corpo. É pela expressão atribuída por outrem que o ato performático ganha significado, dado que o corpo aparece e é visto pelo espectador.

A performance é vista, sentida e vivenciada pelo outro que a acompanha no tempo e no espaço, mesmo que a encontre na passagem, num espaço ínfimo de tempo. A performance deixa marcas, às vezes sutis, às vezes graves naqueles que por ela são tocados. O espectador que vivencia a performance pode sublimar, transformar ou esquecer a marca que tentaram lhe imprimir. Pode-se chamar de marca os estados inéditos que se produzem no corpo de um indivíduo, a partir das composições que ele vai vivendo no decorrer de sua existência. Cada um destes estados constitui uma diferença que instaura uma abertura para a criação de um novo corpo, o que significa que as marcas são sempre gênese de um devir.

Principalmente o corpo do artista está sempre em devir, pois a cada novo trabalho, a cada nova apresentação diante do público ele está experimentando diferentes maneiras de se expressar. Numa performance o criador não almeja a busca de uma única forma, ele se presentifica visando compor uma intensidade de formas que marcam seu caráter transitório e instável. O caráter indefinido e impreciso da performance defendido na obra de Cohen é reiterado pelas reflexões do performer e pesquisador Lucio Agra, que celebra também sua indefinição. Segundo Agra, a performance permite novos entendimentos a cada vez que alguém se apodera dela, tornando-a uma construção em incessante devir.

[...] O caráter de expansão da linguagem, sobretudo atualmente; a sua "natural" resistência à apreensão cognitiva racionalista, a sua amplificação geográfica, a sua reverberação em vários contextos (ela mesma sendo um), sua congenialidade a outras formas emergentes de invenção artística que resultam de misturas e apropriações de formas tradicionais ou sucatas culturais, a sua predileção pelo evento efêmero, precário, dificilmente apreensível, a sua resistência às clássicas ordens identitárias, o seu caráter de proximidade ao subalterno, sua expansão em lugares antes ignotos, sua formulação em uma temporalidade espiralada (sem a teleológica perspectiva de um progresso linear-ascendente), a amplitude de seu campo de pesquisa, sua ilógica, sua predileção pelo paradoxo, o experimental. Por que deveríamos abrir mão desta conquista que é dispormos de um modo de dizer/fazer/pensar em arte que resiste às definições? Vamos adiante afirmando a dúvida. (AGRA, 2009/2010, p.6,7)

Agra define a performance como espaço de entrecruzamento de linhagens artísticas, espaço de dúvida, instabilidade e abertura para diversas possibilidades. Poderíamos inferir que a performance se situa numa espécie de encruzilhada, 
lugar em que o artista experimenta contínuas e dicotômicas possibilidades, um ritual que envolve ousadia e risco. O artista-performer por meio de sua criação amplifica as dimensões de sentido, que se constroem por um rico universo de elementos de ordens até aparentemente díspares, mas que se fundem gerando um resultado muitas vezes provocador. "O corpo é sempre uma realidade experimental possível e viva” (GREINER:2010, p.51) e sua “incompletude” é justamente seu passaporte para um caminho infinito de inventividades.

Como dissemos, o corpo na performance não se move objetivando o alcance de uma única forma; ele se presentifica para compor uma intensidade de formas. Mesmo assim, subjaz uma organização estética à intensidade de qualquer performance, sendo esta uma composição de ação que se organiza em meio ao seu caráter provisório e instável. Zumthor problematiza a questão, enfatizando a instabilidade que percorre a denominação do próprio conceito de performance, devido ao fato de esta ser marcada justamente por sua natureza múltipla e de difícil apreensão.

\begin{abstract}
Entre o sufixo determinando uma ação em curso, mas que jamais será dada por acabada, e o prefixo globalizante, que remete a uma totalidade inacessível, se não existente, performance coloca a "forma", improvável. Palavra admirável por sua riqueza e aplicação, porque ela refere menos a uma completude do que a um desejo de realização. Mas este não permanece único. A globalidade, provisória. Cada performance nova coloca tudo em causa. A forma se percebe em performance, mas a cada performance ela se transmuda. (ZUMTHOR, 1993, p.33)
\end{abstract}

Na performance o material a ser trabalhado e permanentemente transmudado é o próprio corpo do artista e sua evolução se efetua na presença e relação com outros corpos (pessoas e objetos), além do espaço e do tempo. No ato performático o artista se torna outros sem deixar de ser o que é, ou seja, sem perder sua essência que o torna único. O performer sabe que se encontra diante de um outro, um outro de si e um outro do espaço e através desta percepção elabora suas criações. Ele se deixa atravessar-perpassar por um estado de exposição criativa de si próprio, mesmo como estado transitivo possível de proporcionar a abertura para o encontro, para a alteridade.

Há que se frisar que o tempo é um dos elementos constituintes da performance e o corpo existe num determinado espaço de tempo. Principalmente quando refletimos sobre a questão musical, há que se levar em consideração que 
os sons se conformam numa sucessão temporal. Na música o som é usualmente empregado para a construção de estruturas temporais e de estratégias de organização dessas estruturas no tempo. Na arte sonora o tempo aparece como condensado ou suspenso.

Refletindo sobre as bases que fundamentam a conceituação de performance, constatamos o quanto o início de carreira de Calcanhotto é marcado por uma acentuada tendência performática. Para a fundamentação de nossa análise, recorremos inicialmente a alguns registros áudio visuais extraídos do período em que ela ainda se apresentava em pequenas casas de espetáculo e era considerada uma espécie de artista "cult” pela pequena e grande imprensa que já começava a desvendá-la. Essa acepção “cult” advinha do fato de que Calcanhotto começou a despontar no cenário nacional com uma proposta musical meio dissonante em relação ao que se presentificava no final da década de oitenta. É fato que ela surge no momento em que floresciam as chamadas cantoras “ecléticas”, ou seja, intérpretes que cantavam um repertório pontuado pela indefinição de gêneros. Marisa Monte, que apareceu no mesmo período, lançou seu primeiro disco com uma miscelânea de canções que iam de Kurt Weill a Candeia, Erasmo Carlos e Tim Maia. Esta artista impressionou a mídia e o público por sua versatilidade; com afinação e segurança transitava entre um repertório vasto e não buscava a princípio ser firmada sob nenhum rótulo que a carimbasse como representante de um gênero específico.

Calcanhotto assim como Marisa Monte se fez notar também pela escolha de um repertório pleno de mesclas, e além disso pela maneira como relia composições de gêneros diversos a seu modo. Esta artista não simplesmente mostrava a opção por um leque de canções de gêneros distintos, mas apresentava um desempenho cênico difícil de classificar. Seria uma sucessora de Nara Leão, com seu modo minimalista de acompanhar-se ao violão? Seria uma sucessora de Elis Regina, pela maneira como utilizava a voz, brincando com seus amplos recursos? Seria herdeira de uma tradição musical mais performática, a exemplo de Eduardo Dusek e Cida Moreira?

Assim que aportou no Rio de Janeiro, a cantora gaúcha apresentava um repertório de feição híbrida, que percorria a tradição das marchinhas e sambas canções (Bandeira Branca, Nunca) aliado a músicas que dialogavam com uma estética mais contemporânea, a exemplo do rock (Rádio Blá). A presença de 
certos elementos kitsch na escolha de algumas composições do repertório da Jovem Guarda (Namoradinha de um amigo meu), acrescidos por sua própria interpretação, também soava de certa maneira intencionalmente dissonante.

Como exemplo de desempenho acentuadamente performático, destacamos um show de Calcanhotto realizado no Teatro Rival-Rio, sob a direção do cineasta Zelito Viana. Com cerca de uma hora e meia de duração, o espetáculo, que obteve uma restrita divulgação na mídia apenas em material VHS, consiste num registro fundamental que expõe o processo de transformação pelo qual a artista passa ao longo de duas décadas de atividade. Apenas voz e violão tomam conta de uma plateia pequena, mas efusiva, que interage a todo tempo com a artista, principalmente nos momentos em que é explicitamente convidada a participar. O figurino composto por blazer, calça verde limão e blusa amarela alude às cores da bandeira nacional e compactua com um repertório que passa por clássicos de Lupicínio Rodrigues, Max Nunes e Laércio Alves, Gilson de Souza, Luiz Peixoto e Vicente Paiva, entre outros.O visual da cantora, em relação ao de hoje, é quase irreconhecível: cabelos cortados em estilo chanel com as pontas para fora e tingidos de um louro claríssimo ao estilo Marylin Monroe, compõem um caráter meio exótico, que tem seu reforço numa maquiagem forte que marca os lábios muito vermelhos em contraste com a pele alva. Mesmo levando-se em conta que a imagem data de mais de duas décadas, a aparência da artista neste vídeo mostra uma intenção acentuadamente provocativa.

Não há nenhum artefato elaborado para o cenário: no centro do palco com fundo negro, apenas Calcanhotto acompanhada por seu violão. Nota-se que as luzes e os enquadramentos simples e quase de feição doméstica não intentam mostrar nenhuma sofisticação tecnológica que suprima a performance da artista. O foco cinematográfico ora incide sobre detalhes de sua expressão facial, ora capta a expressividade inteira de seu corpo. O show é apresentado do princípio ao fim com banquinho, e, violão, e, no entremear de algumas interpretações, são exibidos ao espectador do vídeo alguns registros de um outro show realizado por ela numa outra temporada, possivelmente anterior ao show "Enguiço", pois o cenário e figurino se distinguem.

A performance de Calcanhotto exibida no vídeo dirigido por Zelito Viana revela a desenvoltura da artista, que dá primazia a um toque de humor que envolve grande parte das interpretações. O formato voz e violão dialoga com a 
estética cool da Bossa Nova, contudo a expressividade corporal da cantora alterna momentos mais contidos e expansivos. A câmera se aproxima em close muitas vezes mostrando detalhes do rosto da cantora, principalmente os lábios, que respondem diretamente pela emissão da voz. Na interpretação da música "Injuriado" Calcanhotto constrói uma performance expressionista repleta de ironia, brincando com a letra da canção de Eduardo Dusek, que fala sobre um alguém vítima do excesso de uso de droga.

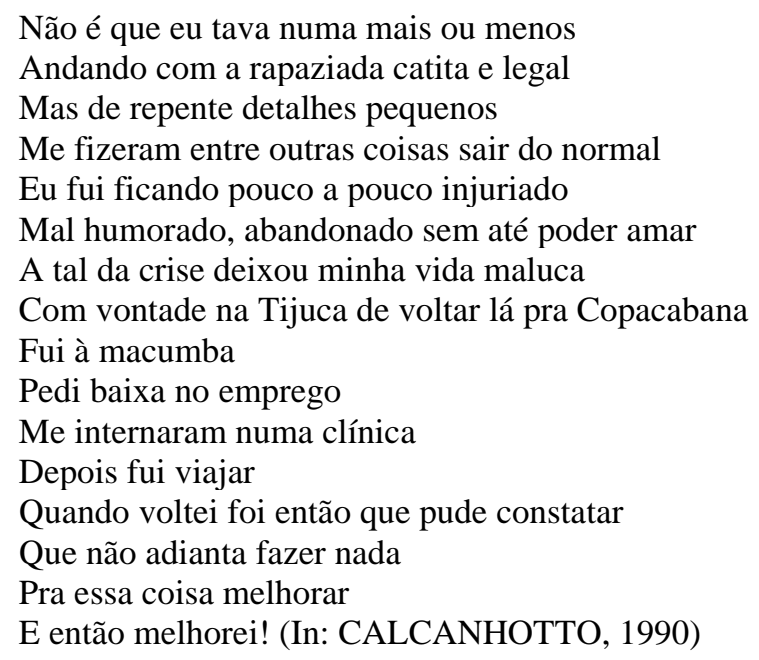

Ela canta várias vezes os versos da canção do começo ao fim, a cada retorno ao primeiro verso explicita-se uma mudança em sua performance vocal. A levada do violão vai adquirindo um ritmo cada vez mais acelerado e sincopado na proporção da mudança do entoar da voz de Calcanhotto, que imita a voz masculina e satiriza os movimentos faciais cada vez mais "travados" do usuário descontrolado de cocaína. Toda a performance de "Injuriado" é realizada com muito humor e descontração, levando à recepção calorosa do público.

O show, registrado por Zelito Viana, contém grande parte das canções divulgadas em "Enguiço", álbum de estreia da cantora, além de outras que já vinham sendo continuamente interpretadas por ela ao longo de suas apresentações nas pequenas casas de shows. "Namoradinha de um amigo meu" (Roberto Carlos/Erasmo Carlos) recebe uma leitura singular da cantora: seu violão que se firma com batidas fortes conduz uma base sonora pulsante para a expressividade de seu canto cheio de interferências cômicas. Nos últimos versos ela brinca com as palavras “e por que não com ela”, transformando-a em "e porque não comê-la”, 
insinuando uma proposta de cunho mais erótico. Há uma faceta lúdica que floresce com revestimentos de humor nas canções em que ela intenciona mostrar uma leitura mais provocativa: "Namoradinha de um amigo meu” coloca em evidência uma canção do repertório da Jovem Guarda, refeita numa concepção que destaca a brincadeira, num sentido quase paródico.

O espetáculo todo se sustenta pelo primado do banquinho e violão, o que remete ao estilo tradicionalmente difundido pelos intérpretes da Bossa Nova. No entanto, o desenvolvimento corporal de Calcanhotto é consideravelmente mais expansivo do que caracteriza a expressividade do gênero. Em "Sem compromisso", ela explicita uma notável movimentação que vai além da contenção cool bossanovista: mesmo assentada e abraçada ao violão, a artista reproduz o movimento da dança sugerido nos versos da canção ao mover as pernas num ritmo musical. Essa sua expressividade que se dá tanto no desempenho do corpo, como em suas expressões faciais, dão ao número uma dimensão performática que enfatiza a sua relação com o publico, visando a uma permanente interatividade. Conforme argumenta Zumthor, a performance é ato de presença no mundo e em si mesma. Nela o mundo está presente. Sendo assim, não é possível falar da performance de um artista de maneira unívoca, sem situá-lo com o momento e ambiente em que vive. A experiência corpórea da cantora revela seus diálogos com o mundo e com o universo das artes; em cada performance executada por ela emerge um novo ser, tanto em sua essência enquanto cantora, como em sua intenção e inteiração no campo das artes. Nota-se uma ontologia múltipla, em que "várias Calcanhottos" se mostram em aparência, cujo fenômeno determinante pode ser o mesmo em sua essência. Mudam as aparências, mas as causas motivantes se mantêm, na observação e interação do corpo ao mundo. O corpo desta artista é um corpo em estado de incessante devir e este devir é inerente à estrutura da performance, em que nada é definitivo, tudo flui, se modifica, se transforma, se dissolve e se esvai.

Cada performance é única em seu instante, momento e ritmo. Mesmo que o artista esteja atuando num mesmo espetáculo durante uma longa temporada, nenhuma apresentação será exatamente igual à anterior, pois cada uma é movida por seu ritmo singular que se transforma conforme o momento e a emoção do artista. Um cantor pode repetir todas as noites o mesmo show sem modificar a sequência do repertório, cenário e músicos, mas não pode repetir com exatidão a 
emoção que conduziu a expressividade singular de cada instante. Uma performance marca identidade, modifica e redimensiona o tempo, conta histórias e permite que se jogue com condutas repetidas na medida em que o artista prepara, ensaia, apresenta e representa estas condutas. Ao mencionarmos a questão do ritmo único que move o instante de cada performance, estamos falando indissociavelmente do tempo. A arte interfere no ritmo corporal daquele que a constrói e daqueles que a recebem, principalmente quando se trata de uma criação que acontece em tempo-espaço real. Um espetáculo musical ao vivo, a dança e o teatro são exemplos de criações artísticas que requerem a presença do artista e do público para que aconteçam.

O corpo do artista é um espaço de discussão e confronto entre desejos e imposições, fluxos pessoais e coletivos, numa espécie de campo de batalha que negocia as crises de seu próprio tempo e seu contexto de criação e convivência. A arte não se elabora enquanto afirmação de um único artista, mas é o resultado de um estado dinâmico, amplo e complexo de relações. Ela sempre estará imbuída de uma dimensão política na medida em que operar politicamente pela articulação de seus discursos corporificados, afetivos e sensoriais. Por colocar em evidência um espaço de reflexão sobre seu próprio contexto, reelaborando paradigmas e recriando novos modos de organização e percepção, a arte em sua verdadeira essência é capaz de continuamente se recriar numa ampla dimensão política.

O estilo, a forma ou o ritmo imposto pelo artista são a assinatura de sua vontade, a criação de um idioma particular, um projeto de impressões sensoriais que elaboram um cenário imaginário para a vontade do espectador. O artista, por meio de sua criação constrói, uma articulação de vontades através de um idioma que precisa ser partilhado, mas não necessariamente “entendido” de maneira racional. O espectador pode partilhar uma obra acionando sua sensibilidade, seus sentidos. A arte contemporânea sobretudo se encontra focada no âmbito das relações, na intersubjetividade, não apenas como tema, mas como ponto de partida e chegada. Cada obra de arte pode ser entendida como o resultado do desejo do artista em habitar um mundo comum, numa construção coletiva de sentido, partilhada entre ele e o público. Como afirma Deleuze "desejar é construir um agenciamento, construir um conjunto, um conjunto de uma saia, de um raio de sol [...]” (DELEUZE: 1988/1989). Sob o olhar do teórico o desejo se fundamenta pelo construtivismo. 
Dando continuidade ao pensamento Deleuziano, podemos afirmar que não há potência em arte que não passe pelo agenciamento do desejo. O criador não ambiciona apenas produzir arte, mas deseja “incomodar" o público produzindo sua arte num contexto, gerando impactos nos corpos daqueles que a recebem. Desejar é também delirar e "delira-se sobre o mundo inteiro, delira-se sobre a história, a geografia, as tribos, os desertos, os povos” (DELEUZE: 1988/1989).

A criação do artista segue seu percurso que funde inovação e resistência, esta no sentido de que seu trajeto não deixa de ser um movimento que incorpora continuamente a criação de novas misturas sensoriais, na ampliação da sensibilidade, na produção de configurações mutáveis de desejos abertas para o encontro e para a alteridade. O criador necessita deixar sempre um espaço para que seu corpo vibre, com sua respiração e pulsação singulares. As filigranas de sensibilidade e percepção que tornam o artista um ser único em sua criação, não se restringem ao universo musical, com o qual estamos lidando mais diretamente. A entrega ao sentido e instante da criação se amplia para todas as modalidades artísticas na medida da intensidade do artista. Quando pensamos em performance e comportamentos cênicos, inevitavelmente nos remetemos ao universo dos atores, que continuamente lidam com a transmutação das emoções. A atriz Irene Ravache comenta sobre sua entrega visceral à criação de um personagem:

A paixão explode, quando você começa a emprestar o seu corpo, seu cabelo, sua cara, seus sentimentos, enfim, a sua alma, para a personagem. Nesta fase você discute com o autor, contesta-o. Se ele diz no texto que a personagem chorou desconsoladamente, não tenho escrúpulos em achar que não é bem assim, que discordo, que ela chorou, mas parcimoniosamente. Se eu pego o caráter da mulher e viro-a do avesso, tenho o direito de saber como ela reage. Sei que vou dar o recado do autor, mas não necessariamente como ele escreveu. Para o que está escrito virar ação é necessário uma pessoa e esta também tem coisas para dizer [...] O autor tem uma personagem e entrega-a para um ator. Pronto, estabeleceu-se a confusão. (CARVALHO, 2004, p.70, 71)

A fala de Irene Ravache diz respeito a sua singularidade de atriz, mas que muito tem a ver com o universo do intérprete de uma música. Ela comenta sobre como se dá em parte o seu processo de entrega a criação, a maneira como se apossa de um discurso alheio, entregando todo o seu corpo à invenção do personagem. Este corpo é uma via aberta para contínuas experiências e transformações, a cada nascer de um novo personagem abre-se este corpo-tela, espaço amplo de sensibilidades e percepções que serão manchadas, sujadas, com a 
vida impressa pela artista. A atriz Fernanda Montenegro, em sua autobiografia "O exercício da paixão”, reflete também sobre a questão da singularidade do artista, sua assinatura, sua marca única:

Não há dois atores iguais, não há dois seres humanos iguais. Na minha geração, na geração que me antecedeu, na que veio depois de mim, cada ser ator tem uma respiração própria, uma visão de mundo, um somatório de experiências e uma conformação genética que fazem dele uma personagem única. [...] A minha respiração é a minha respiração e eu assino embaixo. E o caráter dessa assinatura nasceu comigo e morrerá comigo. É acaciano dizer que eu tenho uma personalidade só minha. Não estou no teatro para ocupar o lugar de nenhuma atriz viva, ou morta, ou que venha a nascer. Tenho o meu lugar, bom ou mal, bem realizado, ou mal realizado, e é só meu. Só esse lugar me interessa, porque só essa é a minha história, só essa é a minha capacidade ou a minha incapacidade.Tudo isso, como diz Clarice Lispector, "forma um sangue que não se repetirá mais". (RITO, 1990, p.100)

Fernanda Montenegro também se exprime sobre a questão da singularidade do artista, características que fazem dele um ser único, com seu próprio ritmo, tempo e respiração. O dado valoroso se encontra justamente nesse caráter extraordinário e irreproduzível do verdadeiro artista. Nesta fala ela exalta a validade de sua própria assinatura, sua marca inigualável. Por meio dessas associações, percebe-se o quanto o teatro e a música são linguagens artísticas que estabelecem entre si profundas relações. Ambos possuem como elemento primordial de trabalho a emoção e esta consiste no componente do corpo que integra o conteúdo do saber sensível. A emoção é um estado corporal preciso, é ela que elabora o intermédio entre as vivências do indivíduo e suas respostas comportamentais. O corpo é o instrumento de comunicação, seja do ator seja do cantor, todo o espetáculo cênico tem este como instrumento propulsor de signos. O artista é o coreógrafo de seus próprios movimentos, todo o significado da cena se dispõe em seus movimentos, nos gestos, nas expressões faciais que ele oferece para o espectador num fluxo comunicativo.

O cantor, assim como o ator diante de um texto alheio, expande seu universo sensível para imprimir sua marca. A sua forma de entendimento da letra, as palavras que serão por ele cantadas estarão a serviço de sua própria percepção. O cantor ao escolher uma música de um outro compositor para interpretar, utiliza seus próprios recursos vocais e sua criatividade para instaurar sua versão única. Calcanhotto exerce o dúbio ofício de intérprete de suas próprias composições e de 
canções alheias. Quando sua voz se coloca a serviço da interpretação de músicas de outros compositores, se torna ainda mais evidente sua assinatura.

A artista, ao eleger músicas de distintos compositores, deixa manifestar o seu modo de compreensão da canção na maneira como adapta sua voz ao entendimento dos versos e à cadência dos sons. Cada interpretação requer uma compreensão própria; a canção por si só aponta caminhos de leitura que a cantora deve buscar até encontrar sua forma ideal. Cada compositor traz o seu modo musical implícito em sua canção, seu estilo, que por si só o faz diferente de outro compositor. A relação entre intérprete e canção pode se efetuar num sentido pleno de apropriação por parte do cantor, que estabelece uma comunhão com a música, resultando num casamento perfeito entre som e voz. Conforme Zumthor define, duas leituras não podem ser vocalmente idênticas, nem, portanto, ser portadoras do mesmo sentido, mesmo que partam de igual tradição (ZUMTHOR: 1993). “A tradição, quando a voz é seu instrumento, é também, por natureza, o domínio da variante; daquilo que, em muitas obras, denominei movência dos textos" (ZUMTHOR,1993, p.144). Ele argumenta que a movência é uma criação contínua. A poesia vinha acompanhada de um canto em grande parte da Idade Média, nesse sentido poesia e música tinham em comum o fato de serem constantemente "rememoradas" e re-elaboradas pela performance. Essa reflexão que o crítico traz, com base num tempo decorrido, ainda pode ser aplicada aos dias atuais, a assinatura rasurante de Calcanhotto impressa em suas interpretações demonstra a sua habilidade criativa diante de textos poético-musicais em constante movência.

Calcanhotto, no espetáculo registrado em VHS, deixa em evidência o forte diálogo que estabelece com o público: ela faz dos espectadores participantes ativos, na medida em que dão complementariedade a sua atuação. De acordo com Zumthor, a performance, ato de comunicação que, como tal, refere-se a um momento tomado como presente, significa

a presença concreta de participantes implicados nesse ato de maneira imediata. Nesse sentido não é falso dizer que a performance existe fora da duração. Ela atualiza virtualidades mais ou menos numerosas, sentidas com maior ou menor clareza. Ela as faz "passar ao ato", fora de toda consideração pelo tempo. [...] A performance é então um momento de recepção: momento privilegiado, em que um enunciado é realmente recebido. (ZUMTHOR, 1993, p, 50) 
Zumthor menciona a performance e sua ocorrência em tempo real, em que o artista, com seu ritmo, forma e estilo, impõe sua assinatura que o singulariza. O performer partilha com o público seus conhecimentos e experiências, cujo objetivo é fazer com que o espectador compreenda primordialmente pelos sentidos. Como defende Susan Sontag, uma obra de arte necessita ser abarcada não unicamente como algo interpretado, mas também como tratamento do inexprimível. Nota-se, no espetáculo dirigido por Zelito Viana, a intenção de Calcanhotto em trabalhar sob as fronteiras do inexprimível, em que sua atitude provocativa visa deixar sob a plateia uma sensação de dúvida, inquietude, suspensão. A arte em muitos aspectos diz mais pelo não dito do que pelo escancaradamente explícito. Sontag define:

No sentido mais estrito, todos os conteúdos da consciência são inexprimíveis. Mesmo a mais simples sensação é, em sua totalidade, indescritível. Toda arte, portanto, precisa ser compreendida não apenas como algo interpretado, mas também como um certo tratamento do inexprimível. Na arte mais erudita, estamos sempre conscientes de coisas que não podem ser ditas (normas do "decoro"), da contradição entre expressão e a presença do inexprimível. Os artifícios estilísticos são também técnicas de suspensão. Os elementos mais poderosos de uma obra de arte, frequentemente, são seus silêncios. (SONTAG, 1987, p.48)

O silêncio do corpo é o lugar onde as forças impositivas se evidenciam e se calam simultaneamente, e pode-se vislumbrar, por alguns instantes, um pequeno espaço, livre e indefinido, no qual tudo pode vir a ser ou transformar-se. O mais instigante no momento da performance não é o instante em que o receptor consegue traduzi-la, captá-la integralmente, mas o instante exato de sua estranheza, quando a criação do artista consegue desprende-lo de sua fixação em realidades já codificadas e até saturadas.

Os processos de criação ocorrem no âmbito da intuição. As múltiplas opções e decisões que surgem no trabalho de um artista e delimitam a sua criação, não se reduzem ao conhecimento consciente. Os mecanismos intuitivos tornam-se conscientes na medida em que são expressos, ou seja, na medida em que o criador lhes dá uma forma. A consciência por si só não é algo acabado ou definitivo, ela vai se compondo no exercício de si mesma, num processo dinâmico de constante renovação.

Nos processos de conscientização do indivíduo criador, a cultura exerce um papel fundamental, pois influencia seu senso perceptivo. Ela é importante no 
sentido de que orienta seus interesses e íntimas aspirações, sugerindo possíveis ou desejáveis formas de participação sociais, objetivos e ideais. A cultura orienta o ser sensível ao mesmo tempo que orienta o ser consciente. Nesse sentido a sensibilidade do indivíduo é aculturada e orienta o seu fazer e imaginar.

Entre pequenos silêncios e fissuras, Calcanhotto dá margem à riqueza de suas interpretações, que visam continuamente a desestruturar o lugar comum. Em seu modo de cantar que impõe modalidades rasurantes, como definimos detalhadamente no capítulo anterior, ela mexe com os pilares de estruturas já codificadas e insere sua marca própria. A maior parte das interpretações da artista, evidenciada no show dirigido por Zelito Viana, expõe uma intenção rasurante, em que ela propositalmente subverte o modo tradicional da interpretação. "Pierrô apaixonado" (Lamartine Babo e Noel Rosa), conhecida como marchinha de carnaval, recebe uma levada peculiar da cantora ao violão, que dá destaque a uma performance mais visceral em relação à dos compositores. A leveza da concepção sonora desta clássica marchinha é substituída por uma leitura mais agressiva, em que o toque das cordas do violão imprime uma sonoridade mais forte, bem projetada para fora, em consonância com a voz, que também contraria a docilidade da interpretação original. O diálogo interativo artista/platéia se realiza nesta canção na forma como Calcanhotto convida os participantes a cantarem junto com ela, compondo uma atuação coletiva.

Os recursos técnicos utilizados pelo artista tendem a modificar e se aprimorar conforme a evolução de sua arte. Numa temporada de um espetáculo específico, a cada apresentação o ator/músico se reconstrói em sintonia com as solicitações de seu trabalho. Em todo artista subsiste uma espécie de motivação interna, que é a mola propulsora de sua inventividade e singularidade. Por meio de suas performances Calcanhotto deixa o espectador-ouvinte entrever uma produção artística permeada de inquietações e questionamentos. Os fragmentos de obscuridade captados pela artista, que, de acordo com o pensamento de Agamben, permitem sua inserção no universo contemporâneo, são por ela reconfigurados e transformados. Há uma melancolia subjacente à criação desta artista que pode ser percebida tanto na composição de seus versos e harmonias, quanto na maneira de interpretar. Essa melancolia é uma parte deste seu olhar meio desencantado, "blasé”, que capta as trevas de seu tempo mas não as decanta inteiramente. Os versos de sua canção “Esquadros” evidenciam um pequeno recorte lírico deste seu 
olhar melancólico que persegue o mundo despedaçado em fragmentos de cores, sons e sensações: "Passeio pelo escuro//Eu ando pelo mundo/ e os automóveis correm/ para quê?/ para onde?” (CALCANHOTTO: 1992).

Calcanhotto, em suas composições e interpretações, deixa transparecer um olhar contemplativo, expressando um lirismo que se mistura a uma sensação de permanente inquietude, como se fosse espectadora de um mundo no qual nunca se enquadra muito bem. Há uma manifestação de um sentimento descontínuo nesta artista que se destaca na composição de versos que trazem uma melancolia revestida de lirismo, como se estivesse sempre num permanente descompasso, tentando resgatar a imagem de uma paisagem perdida, um amor mal realizado, um sonho desfeito: "Depois de ter você, poetas para quê?/ Os deuses, as dúvidas, pra que amendoeiras pelas ruas? Para que servem as ruas?” (CALCANHOTTO: 2002). Sua forma de entoação vocal traz a delicadeza e suavidade do timbre que não explora tons estridentes ou muito graves, mantendo-se quase sempre no território dos tons médios da canção. Essa espécie de manutenção da medianidade sonora da cantora revela também uma aparente de aparência monocórdica, que fortalece o olhar melancólico da artista. Esta artista, por meio da aparente fragilidade de sua voz e da sensação de permanente descontinuidade, deixa perceber que sente as "vértebras quebradas" da contemporaneidade; o traço melancólico que permeia sua expressividade é justamente o ponto da fissura apontado por Agamben. Em Calcanhotto a luminosidade de seu lirismo se superpõe, funde, compactua com a densidade de seu olhar, que apreende as trevas de seu tempo:

O contemporâneo é aquele que percebe o escuro do seu tempo como algo que lhe concerne e não cessa de interpretá-lo, algo que, mais do que toda luz, dirige-se direta e singularmente a ele. Contemporâneo é aquele que recebe em pleno rosto o facho de trevas que provém do seu tempo. (AGAMBEN, 2009, p.65)

Nota-se então que em Calcanhotto a apreensão do lado escuro da contemporaneidade se traduz musicalmente através de performances musicais que acentuam um lirismo melancólico. O olhar contemplativo da artista passeia entre extremidades luminosas e sombrias, como se estivesse quase sempre a um passo da queda: "Observe tudo embaixo ser/ menor do que você,/como tudo é// Abra seus poros, e papilas, e pupilas/À luz da manhã”(CALCANHOTTO: 1998). Noemi Jaffe completa 
Sua força, na verdade, é carregada de inquietação, mesmo que relativizada pelo humor, pela autoconsciência e pela própria elegância. Elegância aqui no sentido arquitetônico. Adriana constrói uma linguagem musical e cênica, uma persona que alcançou ser dona, proprietária de suas inquietações. Como se as fragilidades estivessem sob seu domínio, e nunca o contrário. (NESTROWSKI, 2007, p.14)

Como afirma Jaffe, sob a aparente figura frágil e delicada representada por Calcanhotto, subsiste uma construção altamente elaborada, ousaríamos dizer consideravelmente racionalizada. Há uma aura de racionalidade que envolve toda a concepção estética e musical desta artista, que passa pela elaboração dos versos, harmonias e performance. Ao observarmos os princípios estéticos aos quais se filia e os artistas com que mantém um permanente diálogo, verifica-se que ela dá primazia a uma criação que se singulariza pelo traçado de uma busca inesgotável pela expressividade precisa, limpa, racionalizada. O próprio processo de depuramento de seu canto, observado ao longo de sua carreira, sinaliza a intenção racional que subjaz a sua criação. Não queremos dizer que o canto para Calcanhotto se limita somente a preceitos e enquadramentos técnicos que suplantam a emoção, pois esta não se caracteriza como uma cantora "fria", visto que com sua voz, de extensão não muito longa, é capaz de agregar plateias numerosas. Esta artista traz a emoção filtrada por seu crivo reflexivo que procede da relação estreita que estabelece com o pensar a arte, a música e a cultura num âmbito multidialógico. A “elegância arquitetônica” mencionada por Jaffe pode ser compreendida na performance vocal da cantora, na medida em que para ela há sempre uma espécie de contenção, um esforço que se disfarça em sutileza para jamais ultrapassar sua perspectiva "simétrica", equilibrada. Em termos performáticos, a cantora Adriana Calcanhotto se opõe explicitamente a Cássia Eller, outra que surgiu na mesma época. Cássia, ao contrário, é a exaltação de uma emoção que jorra quase crua, pura, sem freios. Uma força expressiva de natureza vulcânica, explosiva, possuidora de uma técnica que advém muito mais de sua seiva intuitiva do que de um exercício de aprimoramento formal/intelectual. Calcanhotto, por sua vez, traz a elegância sóbria e comedida num estilo performático sem excessos de nenhuma ordem.

Ao refletirmos sobre a questão da expressão cênica de Calcanhotto e o desempenho de sua voz em variadas performances, consideramos pertinente mencionarmos Zygmunt Molik, co fundador, ator principal e (durante cerca de vinte e cinco anos) membro do Teatro Laboratório. Este artista foi essencial para a 
formação do treinamento de voz iniciado por Jerzy Grotowski, diretor de teatro polonês, figura central no século XX, principalmente no teatro experimental, ou de vanguarda. O vasto conhecimento teórico e prático nos fundamentos que envolvem a preparação física e psíquica do ator trabalhados por Grotowski e seu seguidor Molik ainda vigoram e podem ser estendidos para os artistas que trabalham essencialmente a voz cantada, como Calcanhotto. Molik desenvolveu um rico trabalho de exploração das potencialidades expressivas dos atores que envolviam sobretudo a qualidade na emissão da voz. Não somente uma qualidade adquirida por mecanismos de ordem técnica, mas oriunda da fusão entre emoção e receptividade corporal. Calcanhotto, no VHS dirigido por Zelito Viana, traz uma ênfase acentuada no aspecto performático que a liga ao teatro. Molik, em seu trabalho de voz, ressalta a Vida:

Precisamos primeiramente encontrar a Vida. Apenas nessa Vida que se pode tentar colocar, se é que é possível dizer isso, uma voz aberta. E a partir dessa voz precisamos passar da simples vocalização para uma música. E aí colocamos o texto. Então essa é a maneira como trabalho e, por esse motivo, sempre inicio com a prática física. Se o corpo já estiver aberto, começo a trabalhar muito suavemente com a voz, primeiro cantando juntos, depois escutando cuidadosamente e ajustando a harmonia [...] Todos encontram a Vida em si mesmos. A Vida é algo conectado com a vida de cada um, com as memórias, e até mesmo com os sonhos. É isso que chamo de “a Vida”. É difícil de explicar. A Vida, quando encontrada, possui sua forma física e vocal. (MOLIK Apud CAMPO, 2012, p.31)

Essa Vida a qual Molik destaca é a carga de potencialidade emotiva-vocalfísica inerente a cada indivíduo enquanto artista ou não. $\mathrm{O}$ diretor trabalha a expressividade vocal e corporal explorando a singularidade que traz cada ser com suas histórias de vida e memórias. A voz é um instrumento indissociável da emoção e sua qualidade e aprimoramento advém da forma como seu portador lida com suas vivências e sentimentos.

A voz é um dos primeiros instrumentos de que o indivíduo dispõe como meio expressivo; o som antecede o gesto e a escrita e configura-se como o primeiro traço de afirmação da identidade. As crianças choram ao nascer, certamente uma primeira manifestação de vida sonora. Todavia a relação entre voz e identidade é complexa, pois envolve dimensões fonológicas, psíquicas e culturais. Deve-se levar em conta que a voz jamais pode ser compreendida enquanto fenômeno isolado, uma vez que ela se encontra indissociavelmente unida com a audição. Não é possível produzir sons vocais se não formos capazes 
de ouvi-los. Por meio da voz e da escuta o ser humano constrói seu estatuto de sujeito. A voz exerce um papel essencial no desenvolvimento da noção de Eu, que vai possibilitar sua interação com o outro; ela representa uma espécie de ponte entre corpo e linguagem, identidade e alteridade.

A importância da relação corpo-voz do artista não se estabelece numa simbiose dissociada do universo exterior que o circunda. Há necessariamente a existência de um ser-corpo no mundo. Não há corpo absolutamente solitário, dissociado de influências externas. O corpo num ato performático é sempre uma via de mão dupla, receptor e veiculador de emoções e invenções. A criação do performer transforma-o num corpo vibrátil criador/receptor, pois ele precisa se tornar atento ao que dele emana e o que ele recebe e como nele ressoa. Trata-se de um jogo que estabelece suas relações entre o dentro e o fora com suas permeabilidades e limiares, continuamente margeados por fissuras.

Abordar o corpo em sua amplitude necessariamente nos impulsiona a refletir sobre as relações que ele trava com o universo exterior; suas vivências em relação ao espaço são determinantes na construção do senso de identidade. Conforme reflete a educadora Fayga Ostrower, o espaço consiste "tanto no meio como no modo" de nossas experiências vivas. Podemos dizer que o corpo, enquanto dimensão espacial da condição humana, é também nosso meio e modo de ser e estar no mundo.

As formas de espaço constituem tanto o meio como o modo de nossa conscientização, ou seja, o espaço torna-se, simultaneamente, forma das experiências vividas e imagem de seus conteúdos [...] E do mesmo modo, quaisquer conteúdos afetivos que queremos expressar e comunicar aos outros são por nós traduzidos intuitivamente como imagens de espaço. Mesmo quando essa comunicação se dá a nível verbal. Ao dizermos, por exemplo, que algo nos toca de modo profundo ou apenas superficial, usamos intuitivamente imagens de espaço. Quando falamos das qualidades de um indivíduo (um ser in-divisível), como sendo aberto ao mundo ou fechado, como sendo expansivo ou introvertido, desligado, envolvente, atraente, repulsivo, distante, próximo, usamos sempre imagens de espaço. Não há outra maneira possível de conscientizar, formular e comunicar nossa experiência. (OSTROWER, s/d, p.86)

Como argumenta Fayga, todo o campo de apreensão e expressão de um indivíduo encontra-se intimamente ligado às relações que ele estabelece com o espaço. Este procede como um referencial analítico que agrega percepções afetivas e descobertas criativas. É por meio da associação aos referenciais espaciais que o criador se torna apto a fundamentar e comunicar sua experiência. 
A performance de um artista se realiza por meio do tipo de envolvimento que ele estabelece com o espaço, sua proximidade ou distanciamento corresponde ao nível de intensidade ao qual deseja alcançar. Uma apresentação de caráter intimista traz como perspectiva uma relação mais próxima entre criador e espectador, como se verifica no trabalho de Calcanhotto registrado em VHS.

A ironia que prepondera em algumas interpretações do show dirigido por Zelito Viana expõe os diálogos que a cantora estabelece com o espaço exterior, que se dá através de uma relação crítica e muitas vezes irônica com distintas alteridades. Em "Injuriado", ela canta e representa um alguém sem identidade definida, mas que adquire força através de sua performance repleta de inferências. Nesta música a artista concentra a maior parte de sua potência criativa nos movimentos faciais, boca, maxilares, queixo e olhos se esticam e contraem numa movimentação de cunho expressionista.

Embora Calcanhotto neste show se restrinja ao formato reduzido voz e violão, ela utiliza a proximidade com a plateia favorecida por esse caráter intimista para dar mais vigor ao seu desempenho cênico. A predominância de uma postura teatral evidenciada na performance desta artista irá sofrer nítidas transformações no decorrer de seus sucessivos trabalhos. A expressividade do seu canto, neste início de carreira, denota uma empostação diferente; a voz manifesta uma intensidade maior de volume e se projeta de maneira mais expansiva, com uma potência vibratória mais acentuada. Calcanhotto percorre linhas melódicas ascencionais que dão destaque à emissão de notas agudas, como se verifica em sua interpretação de “Nunca” (Lupicínio Rodrigues).

Ela retoma este samba-canção, imprimindo uma leitura própria que se mantém propositalmente numa espécie de entrelugar entre o estilo clássico e uma inspiração mais moderna. O "r" retroflexo que marca definitivamente o modo de interpretação dos cantores da era do rádio, na versão contemporânea de Calcanhotto é substituído pela evidência de notas muito agudas.

A expressividade do canto desta artista evoluirá cada vez mais numa direção oposta ao que se observa neste show. A voz, que, no início de carreira, se sobressai pela alternância de movimentos de aclives e declives, irá mudando sua modalidade vibratória no decorrer dos trabalhos seguintes. A considerável ênfase no desempenho performático, presente no show em VHS, que reproduz a atmosfera do primeiro disco, será substituída por um trabalho musical que incide 
num apuro técnico mais preciso. O foco mais direcionado para a questão teatral, explicitado no vídeo dirigido por Zelito, suplantava de certa maneira uma preocupação mais incisiva com as peculiaridades e minúcias do canto. Importava mais o impacto causado pelo todo, efetuado num desempenho teatral cuja atitude vale mais que o depuramento da voz. Quanto à afinação e equilíbrio entre texturas sonoras, Calcanhotto, no decorrer de sua carreira, vai apresentando um processo de destacável amadurecimento. Ousaríamos dizer que, no espetáculo da temporada de "Enguiço", a artista ainda mostrava certos traços de verve mais amadora, da qual ela vai se despindo ao longo de seu percurso musical. Somente a partir de seu terceiro disco, “A fábrica do poema”, ela define o padrão de emissão vocal que irá seguir durante todos os trabalhos sucessivos. Um canto cool, comedido, preciso.

Observa-se no vídeo que há uma preocupação maior com a representação do que com a interpretação, ou seja, a cantora, neste caso, é muito mais uma atriz que canta do que uma cantora em essência. A intenção da artista se volta mais para a performance, cujo ato de cantar aparece mais a serviço de um enfoque representativo. Em entrevista concedida a jornalista Bia Corrêa do Lago, no programa "Umas palavras”, Calcanhotto revela:

Meu primeiro disco é muito confuso pois eu estava vindo do Rio Grande do Sul, eu fazia um trabalho de performer, eu não era compositora, até podia compor, até podia cantar mas eu gostava de fazer uma coisa híbrida entre o teatro e a música. E fazia nuns lugares, nuns becos, era uma coisa bastante alternativa, era pra ser. Eu fazia shows que eram punk, hard core, cantava pra fora, com fúria. Depois fazia coisas cool, ficava nua no show da Rita Lee. Isso era a minha persona de performer, eu não fui ficar nua no show da Rita Lee como cantora, fui como performer. (http://www.youtube.com/watch?v=EUKZ2okmoyM)

Nesta fala a cantora deixa claro o quanto, no início de sua carreira, era predominante uma preocupação com o desempenho performático. Sua musicalidade encontrava-se a serviço de uma proposta que abrangia não exclusivamente as questões relacionadas ao papel do canto, mas também um projeto híbrido que incorporasse teatro e música. A voz demonstrava propositalmente um aspecto mais "sujo”, que consistia justamente no resultado de um objetivo menos centralizado na emissão do canto e mais na performance cênica. Calcanhotto conectava-se mais com um universo "alternativo" que se manifestava por uma postura mais radical em termos de atitude. A finalidade era 
impactar o público, e esse efeito se fazia por meio muitas vezes de performances mais efusivas, até agressivas.

Em sua versão de "Caminhoneiro" (Roberto Carlos/Erasmo Carlos), Calcanhotto explora o lado lúdico e kitsch dos versos da canção e abusa do humor, através da forma como modula a voz. Sua interpretação dá primazia a um proposital excesso interpretativo que visa a deixar evidente o traço "over" da música. A levada rítmica do violão é pulsante em sintonia com a projeção da voz que se impõe expansiva e sem comedimentos.

Quando refletimos sobre os métodos de criação nesta artista, consideramos pertinente retomarmos as reflexões de Fayga Ostrower, que defende que o processo criativo incorpora um princípio dialético. Este consiste num processo contínuo que se regenera por si mesmo, em que o ampliar e o delimitar representam aspectos concomitantes, aspectos que se encontram em oposição e tensa unificação. A cada etapa, o delimitar participa do ampliar. Existe um fechamento, uma absorção de circunstâncias anteriores e, partindo-se do que anteriormente foi definido e delimitado, abre-se espaço para uma nova abertura. Cada decisão tomada pelo criador representa um ponto de partida, num processo de transformação que está sempre recriando o impulso que o criou.

O potencial criador elabora-se nos múltiplos níveis do ser sensível-culturalconsciente do homem, e se faz presente nos múltiplos caminhos em que o homem procura captar e configurar as realidades da vida. Os caminhos podem cristalizarse e as vivências podem integrar-se em formas de comunicação, em ordenações concluídas, mas a criatividade como potência se refaz sempre. A produtividade do homem, em vez de se esgotar, liberando-se, se amplia. (OSTROWER, s/d, p.27)

Como define Fayga, a criatividade implica uma força crescente que continuamente se reabastece e se refaz nos próprios processos através dos quais se realiza. O disco, por exemplo, é uma obra que pode esgotar-se, no sentido de que limita-se a um enquadramento temporal e espacial, contudo o artista é um ser inconcluso, movido por inquietações, dúvidas e descobertas que o alçam sempre a um incessante fazer e desfazer.

A educadora define sob o termo "tensão psíquica" uma noção de renovação permanente do potencial criador. Esta tensão exerce uma função estrutural e expressiva, visto que é em termos de intensidade emocional e intelectual que as formas criadas pelo artista se configuram e afetam aqueles que a 
recebem. Criar, segundo Fayga significa poder sempre recuperar a tensão, renovála em níveis que sejam suficientes para garantir a vitalidade tanto da própria ação, como dos fenômenos configurados. É de suma importância para o criador o sentimento concomitante de reestruturação, de enriquecimento da própria produtividade, de maior amplitude de seu ser, que se liberta no ato de criar.

A produção artística de Calcanhotto não foge à reflexão desenvolvida por Fayga: em seu percurso criativo a cantora alterna momentos de maior e menor intensidade, distenção e retração. Ela é uma artista que vivencia sua tensão psíquica principalmente na maneira como explicita um desempenho versátil com a palavra performatizada, que, na acepção de Zumthor, se estende em várias modalidades: palavra cantada, falada, declamada e visualizada. O teórico argumenta a favor de "graus de performaticidade", o mais alto deles corresponde à performance presencial, composta por artista e público presentes no mesmo espaço. Para Zumthor até mesmo a leitura de um texto impresso é considerada performance, neste caso situada num grau mais baixo de performaticidade. Para o crítico vale é o instante de interação entre obra e público. Essa ênfase na relação obra/público leva em consideração várias gradações valorativas de acordo com o nível da relação entre obra e recepção.

A voz, veículo fundamental na execução da performance, é parte do corpo de quem a utiliza, e este corpo está inscrito no sinal sonoro, mesmo quando este chega ao espectador dissociado de quem o produziu e/ou do tempo no qual foi produzido. Exemplo claro se faz de uma gravação fonográfica ouvida, tempos após ter sido realizada, por um ouvinte que se encontra distante do local em que se deu a gravação. Murray Schafer caracteriza este fenômeno como "esquizofonia”, provocado pela utilização de meios técnicos que permitem a transmissão do som à distância ou a sua captação objetivando futura reprodução. Schafer aponta o telefone, o fonógrafo e o rádio como divisores de águas nos processos técnicos ocasionadores da esquizofonia. Sob a perspectiva da performance, poderíamos inferir que estas tecnologias são o princípio do que Zumthor denominou de “performance mediatizada”, ou seja, a performance cuja presença do intérprete é mediada por algum tipo de tecnologia, como o vídeo. 
É indiscutível que a transmissão midiática retira da performance muito de sua sensualidade [...] O que falta completamente, mesmo na televisão ou no cinema é o que denominei tatilidade. Vê-se um corpo; o rosto fala, canta, mas nada permite este contato virtual que existe quando há a presença fisiológica real [...] (ZUMTHOR, 1993, p. 70).

De acordo com a reflexão de Zumthor, mediante a existência de novos meios tecnológicos, é possível ouvir a voz do cantor por meio do auxílio de vários recursos que, embora assegurem mais amplitude auditiva, muitas vezes ferem o caráter espontâneo que só pode ser devidamente apreendido no instante da execução. Por mais que um cinegrafista tente captar toda a atmosfera de uma apresentação com o máximo de fidelidade, há uma espécie de vazio, uma lacuna que jamais se fecha entre o instante "real" representado pelo momento da filmagem e o instante posterior em que o espectador assiste às imagens e capta os sons guiado pelo olhar fragmentado do editor. Vê-se aquilo que é mostrado; não se faz um passeio livre com os olhos enquadrados numa tela.

A performance da oralidade midiatizada mostra alguns de seus aspectos alterados, com a eliminação da presença física do portador da voz, a recepção passa a não ser mais sempre coletiva, mas em muitas ocasiões individual, que pressupõe um indivíduo em movimento. Acrescido a isso, a performance passa a fazer parte de um processo de interiorização por parte do receptor-ouvinte, que participa com a criação de suas fantasias, no caso de uma gravação registrada exclusivamente em áudio. A mediação eletrônica fixa a voz, exterminando seu caráter efêmero, fugaz, fazendo com que esta se livre de suas limitações mais humanas e se torne mais próxima de algo "artificialmente construído”. Num aparelho de som é possível repetir inúmeras vezes uma mesma canção, sem mais o cerceamento do tempo cronológico. Zumthor defende que a mídia retira a corporeidade da performance, produzindo uma desencarnação, em que perde-se em volume, peso, tatilidade, olfato e presença de corpo.

A questão das articulações da tecnologia na produção artística também está relacionada às formas de circulação da arte na sociedade atual. Novos meios de circulação podem fomentar novos processos criativos, novas maneiras de apreciação e novos públicos. A questão das ferramentas tecnológicas implica uma análise sobre os papéis desempenhados pelo corpo do artista em sua obra e na sociedade como um todo. De acordo com Lúcia Santaella, os novos meios técnicos de produção da linguagem expandem e deslocam alguma faculdade 
humana para o plano coletivo, dando a sensação de que cada indivíduo transitoriamente perde parte de si, visto que a imagem que tem de si e do mundo é modificada.

Ao tentarmos analisar as imagens de Calcanhotto presentes no vídeo devemos levar em conta que cabe a nós sempre uma incompletude, a falta ocasionada pela tentativa de apreensão de um instante não inteiramente vivido, mas que é transposto em imagem virtual já mediatizado pelo olhar do editor e do diretor. As imagens, após sofrerem um processo de edição, são exibidas sob uma perspectiva seletiva filtrada pela intenção do diretor. Principalmente no vídeo dirigido por Zelito Viana constatamos essa fronteira entre espectador/palco $\mathrm{x}$ espectador/vídeo, pois o show não segue contínuo do início ao fim de sua execução, há no entremear das apresentações inserções de outras filmagens que fornecem ainda mais indícios do processo de edição pela qual o material original passou.

Não somente as imagens retiradas de shows formam o arquivo musical de Calcanhotto; vale salientar a descoberta de um material disperso extraído dos bastidores da criação. Encontramos alguns registros da cantora em estúdio que possibilitam a visão de outros desempenhos performáticos, neste caso mais descontraídos, menos preocupados com a questão cênica. O estúdio é o lugar de experimentações, espaço em que se permite errar, consertar, repetir inúmeras vezes até que se alcance o resultado almejado. Apesar da aparente frieza inerente ao ambiente cercado por mesas de som, isoladores e portas de vidro, Calcanhotto aparenta fazer dele um lugar de comunhão, de celebração do instante de criação compartilhada com os músicos que se faz no tocar e ouvir. No estúdio vê-se uma outra Calcanhotto, uma artista que se coloca numa postura de aprendiz, que dialoga com os músicos em caráter de igualdade, visando a dividir experiências sonoras. Neste espaço ela se mostra como uma cantora que não se preocupa exclusivamente com a projeção de sua voz, mas com o efeito da gravação num complexo mais abrangente que incorpora os músicos e técnicos de som.

Destacamos a filmagem de sua gravação da música "Um sequestrador", letra sua colocada sobre a música de Francis Hime e Vinícius de Moraes. Estúdio cheio de músicos, a cantora sentada observa-os acertando os tons para o primeiro ataque. Jorge Helder e Francis Hime organizam a entrada, em seguida Francis canta os primeiros versos numa atmosfera repleta de lirismo e aguarda a entrada 
de Calcanhotto, que entoa as primeiras notas acompanhada pela base composta de guitarra, piano e contrabaixo acrescida por um naipe de violinos. A qualidade da imagem mostra-nos que, embora este seja um registro de bastidor, certamente foi feito com a intenção de uma posterior exibição pública. Sendo assim, consideramos a atuação de Calcanhotto uma performance, levando-se em conta principalmente que havia a consciência da existência de uma câmera que transformaria em espetáculo aquele simples e aparentemente secreto acontecimento.

A artista interpreta “Um sequestrador” dando evidência à substância lírica dos versos por ela elaborados, cuja metalinguagem desponta como tema. O arranjo valoriza cada nuance da palavra que questiona seu próprio caminho, a emissão do canto em duo com Francis Hime enriquece ainda mais a poeticidade da canção.

O registro visual da gravação em estúdio de “Um sequestrador” deixa evidente uma performance que evolui num processo de ação e recepção, a cantora escuta os outros e a si mesma, ao mesmo tempo em que vai elaborando um aprimoramento de seu desempenho vocal. Outro momento destacável produzido em estúdio é a gravação de "Eu vivo a sorrir", parte do making off do DVD "Micróbio vivo”. Toda vestida de branco, calçada com simples sandálias rasteiras, cabelo preso e rosto lavado, ela, de maneira descontraída, canta o samba cercada pelos músicos de sua banda. Davi Moraes toca o violão ao lado de Domênico, que conduz o ritmo na bateria, e Alberto Continentino, no baixo acústico. Impossibilitada de tocar violão devido a uma lesão no punho direito, Calcanhotto somente canta, deixando para Davi Moraes o encargo de dar sustentação à base e ao mesmo tempo suprir a falta de seu violão. Por força maior ela não toca o instrumento em nenhum momento de suas apresentações de divulgação do CD, como afirma:

Tive uma lesão no punho direito provavelmente por excesso de uso porque estava fazendo um projeto de desenho também, eu acho que gastei a mão direita e daí não estou podendo tocar. Com isso vai ser divertido pensar no show, posso escolher sambas complicadíssimos, umas coisas atonais, o Paulinho da Viola mais encrencado porque é o Davi que vai tocar. Eu acho que isso vai ajudar a construir um roteiro que é pensado só do ponto de vista da intérprete não da limitação da instrumentista. Isso vai ser interessante, na verdade já está sendo. Na verdade eu tenho tocado piano, que é uma coisa que não dói o punho, tenho feito canções assim sem instrumento que é um negócio que alarga o espectro 
harmônico, melódico, enfim, eu num primeiro momento me senti totalmente de castigo, mas depois encarei como uma grande oportunidade. (In: CALCANHOTTO, 2011)

A artista se mostra bastante à vontade neste ensaio em estúdio, brinca com os músicos e faz alguns movimentos suaves com o corpo, acompanhando a cadência do samba. O cenário deste estúdio destoa da insipidez comumente vista, em que somente paredes brancas, janelas e revestimentos em pedra compõem uma coloração translúcida, mas sem brilho. Neste surge uma ambiência customizada pela presença de objetos que decoram as paredes; uma obra de arte ali, outra acolá dão um caráter mais personalizado ao espaço musical.

Um outro registro destacável em sua concepção performática encontra-se entre o material extra show disponibilizado no DVD “Micróbio vivo” (2011). Trata-se de uma produção realizada em estúdio e que propositalmente deixa explícito um pouco do seu mecanismo de feitura. Calcanhotto, sentada num banquinho, como de costume, e acompanhada por seu violão, interpreta a música "Maldito rádio", de sua autoria. Dirigido pela própria cantora e com o figurino em tom de terra elaborado por Gilda Midani, ela interpreta sua música numa levada cool. A palavra cool, referida por nós com frequência em relação ao trabalho de Calcanhotto, advém da modalidade cool jazz. O estilo cool jazz é comumente descrito como uma reação aos andamentos acelerados e às complexas ideias melódicas, rítmicas e harmônicas do bebop. Essas ideias foram apreendidas e desenvolvidas por muitos músicos da Costa Oeste americana, denominado também de West Coast Jazz. Esta modalidade destaca-se por seu andamento mais lento, evidenciando uma expressividade sonora intimista. O trompetista Chet Baker é um dos mais destacáveis músicos do cool jazz, sua intepretação com uso de poucas notas, fundamentava-se na intensidade manifestada em sua forma minimalista. O estilo de cantar deste músico, que projetava sua voz de maneira sussurrada serviu de influência a João Gilberto, um dos ícones da Bossa Nova.

Em "Maldito rádio", sobressai a plasticidade do cenário em movimento, composto por uma tela escura posicionada atrás da cantora. Calcanhotto toca os primeiros acordes no violão, enquanto a imagem de uma mão ampliada, projetada sobre o fundo negro, inicia movimentos lentos que vão sugerido figuras. A movimentação das mãos acompanha o ritmo de sua interpretação e imprime uma beleza e originalidade ao enquadramento total formado pela artista à frente com a 
imagem do movimento das mãos ao fundo. $\mathrm{O}$ tom amarronzado de sua roupa, que traz um leve brilho proporcionado pela echarpe caída ao lado do ombro direito, provoca um casamento perfeito com a textura cor de carne da mão que continuamente se transfigura na tela-cenário. A letra da música entoa um lirismo melancólico, que se encaixa com precisão na concepção total da performance.

A performance explicitada na interpretação de "Maldito rádio", retoma em sua proposta plástica o trabalho desenvolvido pela cantora em torno da obra do artista Hélio Oiticica. Nos clipes que mostram as performances de Calcanhotto com os parangolés criados por Oiticica, sobressai a valorização que ela atribui ao movimento. Tecidos coloridos parecem querer voar impulsionados pela movimentação corporal da artista. O Parangolé favorece a individualidade expressiva, visto que o recorte de pano, agregado ao corpo de qualquer indivíduo, adere ao seu próprio senso de liberdade. Em "Maldito rádio" os movimentos centralizados nas mãos de um performer ganham dimensão plástica ao serem projetados sobre uma tela ao fundo de Calcanhotto. Movimento é a palavra de ordem que comanda tanto a performance com os parangolés, quanto o desenho do movimento das mãos em "Maldito rádio". Torna-se interessante frisar a intencional ausência de fronteira entre bastidor e espetáculo, dado que nos últimos instantes da interpretação da música o performer é revelado.

Impulsionados pela questão performática, cogitamos sobre as relações que se estabelecem entre a voz e a performance. A voz de Calcanhotto, a serviço da performance, consiste numa subversão ou ruptura da clausura do corpo, tal qual diz Zumthor. Ela atravessa o limite do corpo sem rompê-lo, significa o lugar de um sujeito que não se reduz à localização pessoal. A voz desaloja o sujeito de seu corpo, pois este enquanto fala faz habitar a sua linguagem. A linguagem simultaneamente revela um limite e o libera dele.

A observação de registros da artista em estúdio expressa um desempenho diferenciado em sua performance, que deixa propositalmente em destaque um caráter mais espontâneo, como se tudo fluísse no calor da hora. Em um pouco mais de duas décadas de contínua atividade, Calcanhotto se destaca por sua produção, que se mostra em permanente diálogo com outras categorias artísticas além da música, como a literatura e as artes plásticas. Sua relação indissociável com a literatura está explícita em performances que mostram leituras suas de 
poemas e parcerias com poetas, a exemplo de Ferreira Gullar, Waly Salomão e Vinícius de Moraes.

Em "Palavra (En)cantada", filme de Helena Solberg que tematiza a afinidade entre literatura e música, Calcanhotto marca sua participação, deixando evidente sua proposta poético-musical. O filme se dedica a mostrar a profunda relação entre poesia e música no cancioneiro nacional através de entrevistas, imagens de arquivo e performances de músicos como José Miguel Wisnik, Lenine, Chico Buarque, Tom Zé, Maria Bethânia, entre outros. A abertura destaca a voz de Calcanhotto, que canta à capela "Chanson do i’ll mot son plan e prim”, do poeta provençal Arnaut Daniel. A voz da cantora se abre juntamente com os créditos que anunciam as participações do filme, mostrando a afinação e suavidade de sua interpretação. Destaca-se o colorido impresso pela emissão sonora da cantora, que incide numa projeção minimalista, como de costume.

A música minimalista constitui um gênero originário dos Estados Unidos, que pode ser às vezes denominada também de música experimental. Sua origem se deu na década de sessenta, com sua base na harmonia consoante, em pulsações constantes ou nas lentas transformações. Em muitos casos transparece a reiteração das frases musicais em pequenas unidades como figuras e motivos. O minimalismo enquanto movimento musical se expandiu até tornar-se o estilo mais popular da música experimental do século XX. O estilo minimalista de tocar levou à exacerbação seus processos de repetição. Mas ele não se define apenas pela repetição, mas sim por processos sistemáticos de repetição. Steve Reich, em seu manifesto minimalista, "Writings about music”, publicado em 1974, define:

\begin{abstract}
Eu não quero dizer processo de composição, mas sim obras que são literalmente processos. O que é distintivo em um processo musical deste tipo é que ele determina todos os detalhes, de nota para nota, de uma composição, e toda a sua forma simultaneamente. Estou interessado em processos perceptíveis. Quero ser capaz de ouvir o processo acontecendo através do fluxo de toda a extensão da música [...] Processos musicais podem nos dar contato direto com o impessoal e também um tipo de controle completo[...] por esse "tipo" de controle completo eu quero dizer que, ao fazer esse material se articular através desse processo, eu controlo completamente todos os resultados, mas também aceito todos os resultados sem mudanças”(REICH, 1974, p.9,10).
\end{abstract}

As obras minimalistas possuem como própria essência a escolha por processos de repetição, nítidos e perceptíveis. Estes vão ordenar toda a sua micro e macroforma. Em sua estrutura formal as obras minimalistas apresentam longa 
duração, e no seu desenrolar não revelam mudanças abruptas ou qualquer recurso de contraste que afete drasticamente sua condução melódica. De forma geral, a evolução musical minimalista se dá em decorrência de um processo que se articula de modo gradual e quase imperceptível. Nesse sentido a forma pode ser avaliada como circular e contínua, isenta de objetivos direcionais ou dramáticos. Quanto às estruturas harmônicas frequentemente utilizadas nas obras minimalistas, destacam-se encadeamentos estruturais simples em que o ritmo tende a ser lento. Em função de um foco que incide num processo rítmico e formal contínuo, as linhas melódicas expressivas que sugerem início e fim de frases, não cabem na concepção sonora minimalista.

A questão da ênfase na relação intrínseca entre poesia e música, abordada em "Palavra (En)Cantada”, atravessa um longo período da história e se mantém até os dias de hoje, sendo problematizada no filme inicialmente por meio da fala de Calcanhotto. A cantora elucida o indissociável casamento entre a linguagem poética e musical, evidenciado nos músicos que propagam a alta poesia através do canto.

Os trovadores provençais lidavam com uma coisa entre a música e a poesia, né? É tão bonito, isso. O que me maravilhou no primeiro momento não foi a música, porque eu conheci a música só depois. No primeiro momento foi a qualidade da poesia, eu acho que o impulso de transmitir alta poesia através do som e do canto permanece. É o que se pode dizer eu acho, do Chico Buarque, do Caetano, dessa linha. Acho bonito esse eco, no Brasil, na língua portuguesa (In: SOLBERG, 2009).

A participação de Calcanhotto é de considerável importância, visto que seu trabalho se compõe essencialmente através do diálogo entre a poesia e a música. Estabelecendo-se na linhagem da grande tradição musical que traz a palavra como estatuto poético, a artista pode ser vista como uma espécie de seguidora de uma geração que foi capaz de colocar a letra de música no mesmo nível de complexidade e densidade que o poema. Chico Buarque e Paulo César Pinheiro são dois nomes exponenciais presentes no filme e que elevam a letra de música a categoria poética. Como explicita Chico Buarque, em sua canção metalinguística “Uma palavra”, a palavra na canção é alvo de um depurado exercício que se equipara à poesia. 
Palavra prima

Uma palavra só, a crua palavra

Que quer dizer

Tudo

Anterior ao entendimento, palavra

Palavra viva

Palavra com temperatura, palavra

Que se produz

Muda

Feita de luz mais que de vento, palavra

Palavra dócil

Palavra d'agua pra qualquer moldura

Que se acomoda em balde, em verso, em mágoa

Qualquer feição de se manter palavra

Palavra minha

Matéria, minha criatura, palavra

Que me conduz

Mudo

E que me escreve desatento, palavra

Talvez à noite

Quase-palavra que um de nós murmura

Que ela mistura as letras que eu invento

Outras pronúncias do prazer, palavra

Palavra boa

Não de fazer literatura, palavra

Mas de habitar

Fundo

O coração do pensamento, palavra (FERNANDES, 2004, p. 264)

A palavra, matéria prima da criação buarqueana, é substância viva que percorre os elementos constitutivos básicos (terra, água, ar e fogo), arremessando o mundo captado por seu olhar de poeta nos interstícios da linguagem. A palavra sobressai como elemento articulador da criação do letrista, que a repete incisivamente caracterizando-o plenamente no corpo de seu texto-palavra. Conforme define Diniz, no ensaio "A voz e seu dono": "Uma palavra conduz a voz que se cala de um poeta já mudo, que se confessa sujeito e objeto da escrita, seu criador e sua criatura, escrevendo e sendo escrito" (FERNANDES, 2004, p. 265).

A palavra adquire supremo valor poético na música popular brasileira, sobretudo a partir de Vinícius de Moraes. Suas parcerias elaboradas com Tom Jobim atingem o ápice da elevação poética e revelam a força do poder lírico da palavra empregada a canção. A letra de música difere do poema no sentido de que é composta para adaptar-se a uma camada sonora, mas não perde em peso qualitativo. Poesia e música são faces indissociáveis que se alternam em suas formas de composição. Wisnik, em depoimento a Helena Solberg, destaca a 
predominância da oralidade na cultura brasileira, que suplanta a existência escrita, bacharelesca.

A cultura no Brasil é muito oral, muito rítmica, muito musical, muito corporal e muito festiva. Acho que a literatura, quer dizer, a cultura letrada nunca se implantou completamente no Brasil, no sentido de você ter uma vida cultural baseada em publicações, leituras, grande número de leitores. Passou-se muito diretamente dos meios orais para o rádio, para a televisão, para os meios audiovisuais. Eu sinto o quanto a literatura, aliás o quanto a música popular no Brasil é uma ponte que junta, por exemplo, para gerações que chegam e que a gente vai ensinar literatura, o quanto a música popular permite você estabelecer um contato entre a literatura e o repertório desses alunos, dessas gerações. Criouse uma situação que não existe propriamente em país nenhum desse jeito, que é uma canção popular fortíssima que ganhou uma capacidade de falar, quer dizer, de cantar para auditórios imensos e levar para esses auditórios poesia de densa qualidade, de sutileza, de riqueza e, ao mesmo tempo essa imediatez, essa leveza que a canção também tem. (In: SOLBERG, 2009)

Wisnik destaca a questão da supremacia de uma cultura ligada à oralidade no Brasil, que favoreceu sobretudo a intensa propagação da música popular brasileira, de maneira sui generis. A experiência musical vivenciada por Calcanhotto e desenvolvida em seu trabalho demonstra o quanto ela agrega a música e a literatura como componentes complementares e indissociáveis em sua produção criativa. Pelo fato de Wisnik se dividir entre a vida acadêmica, no ofício de professor de literatura brasileira, e entre o universo criativo de compositor, por meio de suas músicas, torna-se capaz de testemunhar o poder de acesso da canção brasileira em outras vertentes, como é o caso da universidade.

O diálogo permanente que Calcanhotto realiza com a literatura se pratica de maneiras múltiplas. Poderíamos dizer que mais do que a própria música, a poesia é o veículo fundamental de sua expressão criativa, pois é primeiramente através dela que a cantora entrevê o mundo e fomenta sua criação. Um poema sob seu olhar pode ser alvo de várias experimentações, transformar-se em canção, desenho, performance ou o que mais sua inventividade aprovar.

A poesia, a música e o corpo já estabeleciam uma relação antes da difusão da escrita, pois o poema arcaico ou primitivo apresentava um canto, acrescido de um acompanhamento musical e mais uma pessoa para dar vida ao conjunto. Tempos mais tarde, mesmo ocorrendo a cisão entre a poesia e a música, perdurou um sistema de ritmos e repetições quando recitado. Conforme Zumthor, as transmissões orais da poesia supõem uma voz, a qual supõe um corpo para representá-la. A corporeidade implica o peso, o calor e o volume real do corpo, do 
qual a voz é expansão. Ele apresenta essas contiguidades corpóreas como características da vocalidade e elementos fundamentais a toda performance.

O poema "O elefante”, de Drummond, recebe uma interpretação sóbria da cantora, de frente para a câmera que dirige o foco do início ao fim para o seu rosto; ela diz os versos num ritmo constante, linear, dando vigor a cada palavra. O ato performático da artista se evidencia através de sua representação da figura gauche, sóbria e comedida do poeta. A contenção que marca a postura cênica de Calcanhotto se faz em caráter proposital, como se reproduzisse o estilo de Drummond, poeta comumente caracterizado por seu comportamento retraído, quase enrijecido. Por meio de um ato mimético, a cantora se apropria performaticamente da imagem do homem-poeta Drummond difundida pelo senso comum. Ela se despe de qualquer excesso de movimentação facial e sua leitura dá ênfase ao substrato lírico do poema. Sua fala obedece a uma cadência linear, que, em seu evoluir não apresenta ascensões ou quedas tonais que suplantem a intenção melódica subjacente ao poema.

A performance elaborada por Calcanhotto para o poema "O elefante" demonstra em sua configuração o quanto esta artista trabalha com a valorização de uma musicalidade intrínseca: o poema é lido apenas sob o despontar de sua própria essência, sem nenhum adorno que o altere substancialmente. Em vários depoimentos e entrevistas ela declara a importância atribuída à literatura em sua vida e criação.

O lance de poesia só entrou na adolescência quando eu comecei a ouvir uma rádio que tinha em Porto Alegre que só tocava música brasileira, o Fagner cantando Cecília Meireles, o Vinícius de Moraes cantando, aquela voz e eu dizia isso tem uma coisa aí atrás e assim eu ouvi grandes poemas. Quando eu ouvi Traduzir-se na rádio eu falei, isso se tiver ao meu alcance eu daria a vida para fazer isso, veicular a alta poesia na rádio popular. Eu achei a coisa mais linda do mundo como aventura para a vida. Porque como eu comecei a ouvir nessa época exatamente os meus discos, parei de ouvir só o que os meus pais ouviam e só o que as babás ouviam e descobri os artistas da palavra, descobri Maria Bethânia e a partir de Maria Bethânia descobri o Caetano. E aí eu vi que naquela turma do Caetano tinha um negócio, eu não me senti tão só quando descobri aquela galera. Por causa disso, eu não vou me lembrar dos ganchos, mas eu fui parar na coisa do modernismo. Eu descobri então Oswald. (http://www.youtube.com/watch?v=Hd904ovYJMA)

Esta fala extraída de uma conversa entre a cantora e o poeta Chacal, no programa "Livros que amei”, explicita o quão a literatura é determinante na formação existencial e artística de Calcanhotto. Vê-se que, por meio de sua 
contemplação da palavra cantada, com destaque para o substrato poético, ela projeta sua aspiração lírico-musical. A poesia para esta artista é uma espécie de fio condutor que abre e expande suas relações com a arte, o mundo e a criação. O que a seduziu na construção lírico-musical dos artistas da palavra lhe serviu de inspiração, paradigma para que ela construísse uma obra também voltada para esse foco. Fazendo um percurso por seus discos, entrevistas, imagens e performances, nota-se que toda a sua carreira é construída sob a relação literatura e música. A poesia dá título a discos seus como “A fábrica do poema”, impulsiona sua participação no cinema como em "Palavra (En) cantada", fomenta sua inventividade pictórica como mostram os livros “O poeta aprendiz” e "Melquior o mais melhor".

Entre imagens dispersas encontradas no youtube, ressaltamos o registro da interpretação da artista elaborada para o poema "Poética do Eremita", da poeta portuguesa Fiama Hasse, divulgado na temporada do show Maré, mas que nunca obteve registro em CD. Vestida com um longo manto vermelho, ela canta sua música composta para o poema acompanhada por um violoncelo tocado por si própria. Os versos recebem uma leitura musical pungente, com uma ênfase dramática em que a voz de Calcanhotto, numa emissão mais projetada para fora, se une às variações produzidas pelo som encorpado e predominantemente de feição mais aguda do instrumento. Trata-se de uma "exótica" performance da artista, visto que seu instrumento de trabalho sempre foi o violão. A interpretação da cantora dá proeminência a uma levada entrecortada por pequenas pausas que valorizam a secura dos versos do poema.

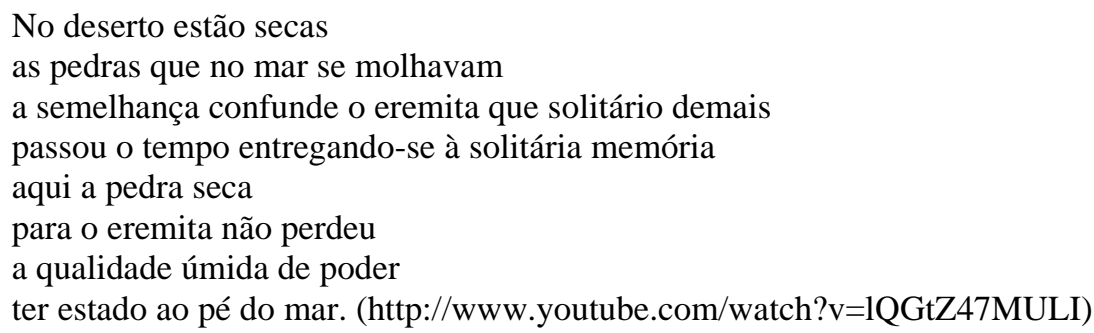

Fiama Hasse (1938-2007) exerceu o ofício de poeta, dramaturga, ficcionista e ensaísta. O experimentalismo é uma marca pulsante em sua criação poética, cujo modo de composição traz a palavra como centro do poema, muitas vezes em sua forma propositalmente desordenada de acordo com uma composição 
que exalta a desconstrução como lema. Observa-se que Calcanhotto escolhe fazer uma música para um poema desta autora que carrega em seu estilo a assinatura de um apuro estético que se filia a correntes experimentais à maneira de Stravinsky, Schoenberg e John Cage. A cantora aproveita de antemão a inclinação de verve experimental de Fiama Hasse para elaborar uma performance que dá continuidade a essa proposta. O violoncelo tocado pela artista explora percursos sonoros que imprimem ondas sonoras aleatórias, não há uma construção musical plenamente estruturada no sentido harmônico para servir de base ao poema. A nosso ver Calcanhotto não compôs uma música no sentido tradicionalista da acepção, ou seja, não desponta um encadeamento melódico formado por uma sequência de acordes. Ela experimenta algumas notas que produzem uma espécie de "ruído”, que em sua proposta se encaixa musicalmente no poema.

"Poética do Eremita" mostra como, entremeado ao canto, submergem intencionalmente pequenos silêncios, como se a artista tentasse expressar sempre uma lacuna, a impossibilidade de romper com sons e palavras a angústia do não absoluto. Há sempre algo a ser dito, cantado, desconstruído que paira em suspensão. O silêncio se dá como uma tentativa de imprimir sentido ao sem sentido, o indizível.

A voz repousa no silêncio do corpo. Ela emana dele, depois volta. Mas o silêncio pode ser duplo; ele é ambíguo; absoluto, é um nada integrado ao jogo da voz, torna-se significante: não necessariamente tanto como signo, mas entra no processo de significância. (ZUMTHOR, 1993, p.84)

O silêncio definido por Zumthor pode ser entrevisto nas pequenas pausas que a cantora intencionalmente faz em suas interpretações. A pausa atua como um súbito e provocativo instante de suspensão, segundo em que ela abre uma brecha para deixar o público num imprevisto vácuo de dúvidas e expectativas. O próprio silêncio, conforme diz Zumthor, compõe-complementa o significado, não é destituído de sentido. No registro de sua interpretação ao vivo da música “Devolva-me”, executada apenas com o acompanhamento de seu próprio violão, Calcanhotto impõe um mínimo instante de silêncio que complementa o sentido da performance. Este silêncio evoca um amplo campo de subjetividades, que no caso específico desta música pode trazer ao ouvinte, no curto espaço de suspensão sonora, a rememoração da versão original, realizada pela dupla Leno e Lilian, trazendo neste caso um destaque para o aflorar da memória musical. 
A cantora também une performaticamente o universo literário ao musical em sua apropriação cênica do poema "Remix século XX", de Waly Salomão, chamado de "Polivox", que em seu formato labiríntico em forma impressa, exibe um traçado circular cuja sucessão de palavras gira num caleidoscópio sonoro. Essa atuação de cunho teatral faz parte do show "Público", que se notabilizou pelo primado de uma estética minimalista fundada no duo voz e violão. Sentada num banquinho e com um dos pés apoiados sobre uma superfície com um pequeno microfone, ela produz com o bater do pé o ritmo de um falso bumbo que atribui uma musicalidade singular ao poema. A cantora deixa em evidência, entre suas mãos, a folha de papel que serve de suporte para sua leitura, como se esta fosse, no evoluir de sua fala, sendo deglutida pela mesma força que consome as palavras em seu movimento labiríntico. O ritmo do falso bumbo obedece à cadência sonora conduzida pela artista em que as palavras de Waly Salomão, dispostas num desenho aparentemente aleatório, ganham uma nova configuração. A performance construída sobre a ênfase de uma leitura seca do poema "O elefante”, em "Polivox", ganha uma base sonora composta pelo entoar da batida do pé da artista, que reproduz a marcação de um bumbo. A voz da cantora dialoga em uníssono com a base percussiva e precisa do toque de seu pé. Waly Salomão, nos primeiros versos, atrai o leitor para que elabore o seu próprio jogo lingüístico, e Calcanhotto abre sua imaginação criativa para o convite do poeta.

O permanente diálogo que a artista estabelece com o mundo poético se destaca por performances de feição mais iconoclasta, como a elaborada para o poema de Waly, ou por versões suaves em que o seu objetivo maior é deixar em evidência a força lírica dos versos. O poema “Traduzir-se”, de Ferreira Gullar, musicado por Fagner, ganha uma leitura repleta de suavidade e pungência lírica, em que a voz de Calcanhotto mostra, em seu desenho afinado, a substância poética dos versos. O que guia suas escolhas poéticas é o nível de cumplicidade que ela estabelece com os versos alheios, que se transformam sob sua posse:

Eu preciso que as canções me arrebatem e isso em geral vem pela letra, vem pelo poema. Eu preciso daquele poema, eu preciso cantar aquilo, eu preciso ter ele no meu disco, eu preciso estar perto do poema (http://www.youtube.com/watch?v=_a7GpL0QBQk).

Elaborando-se um percurso pela discografia de Calcanhotto, observa-se que em todos os seus trabalhos desponta um diálogo entre o substrato poético e a 
música. Mesmo em "Enguiço", seu disco inaugural, que mostra a prevalência de uma intenção performática, submerge a filigrana poética em "O nome da cidade”, composição de Caetano Veloso inspirada na obra “A hora da estrela”, de Clarice Lispector. Na interpretação desta música, a cantora opta pelo acompanhamento exclusivo de seu violão, que em seu fraseado simples dá mais destaque ao colorido das palavras, trazendo a poesia para o centro da cena.

"Micróbio vivo" é o mais recente registro em DVD de um show inteiro de Calcanhotto. Gravado no dia 15 de outubro de 2011 no espaço Tom Jobim, Rio de Janeiro, o espetáculo traz um forte caráter experimental e performático. Pela primeira vez assiste-se à artista apenas cantando e tocando alguns instrumentos experimentais como secador de cabelo. Em virtude da lesão no punho já mencionada por nós, ela ficou impossibilitada de executar seu instrumento, o violão. A ausência dele favoreceu uma rica exploração corporal por parte da cantora, que mostra seu corpo como portador pluridimensional de sentidos. Destituída do instrumento que antes compunha uma espécie de extensão de seu corpo e facultava de certa maneira a retenção de movimentos, uma vez que a maior parte do tempo ela investia na estética banquinho e violão, a cantora, com todo o corpo solto, dá margem a um trabalho com ênfase na performance.Quase todas as músicas são de autoria de Calcanhotto. O gênero samba, que ela e os músicos da banda reverenciam, é interpretado de acordo com uma concepção muito distante de uma visão cristalizada, enraizada. Sobressai uma homenagem à tradição do samba e de seus grandes compositores, mas que se concretiza por meio de um olhar propositalmente distorcido. O trio de músicos composto por violão (Davi Moraes), baixo acústico (Alberto Continentino) e bateria (Domênico Lancelotte) explora sonoridades rítmicas, mas sem cair num esquema harmônico quadrado. A inventividade e o experimentalismo são pontos altos deste trabalho, que mistura a tradição e a modernidade sem causar atritos.

O figurino é sóbrio, Calcanhotto se veste inteiramente de preto e anula os cabelos deixando-os presos num coque para trás, remetendo-nos à figura de uma bailarina, tal qual Pina Bausch. Esta bailarina alemã, nascida em 1940 na cidade de Solingen, destacou-se mundialmente por seus inovadores trabalhos coreográficos, caracterizados por uma junção entre teatro e dança moderna, os quais refletiam sobre sentimentos humanos de caráter universal, como a tristeza e o amor: 
Em meus trabalhos e em tudo o que faço me ocupo primordialmente das relações entre as pessoas, da infância, do medo da morte e do enorme desejo que todos sentimos por ser amados"(BAUSCH apud BILKSKI-COHEN in GOETHEINSTITUT 2000, p. 79, tradução da autora).

O corpo é território de experiências e experimentações sob o olhar criativo de Pina; suas peças geralmente dramatizam a noção de que o gênero, masculino ou feminino não constitui um fato, mas os vários atos dos gêneros criam a idéia de gênero. Sem a existência desses atos, não haveria nenhum gênero masculino ou feminino, nada. O corpo, em seus significados, passa por muitas releituras que buscam deslocar estruturas estratificadas. O corpo era uma espécie de texto para Pina, e, nesse sentido, ela, ao longo de suas criações, confrontou a significação histórica e cultural dos corpos. Pina entendia o corpo como um ponto de vista representativo de cada ser sobre o mundo e um dos objetos desse mundo, organizando uma dramaturgia focada nas relações dos corpos com o mundo objetivo. A coreógrafa pôs o público frente a frente com o corpo como ponto de vista sobre o mundo, como lugar da experiência perceptiva, como forma de conhecer. Seu teatro-dança impulsiona o espectador para sua própria realidade e exige cumplicidade.

A composição visual da cantora objetiva mostrar uma figura pronta para incorporar o imaginário representativo da figura masculina representada pelo sambista, ou malandro. Os demais músicos também se vestem de preto acentuando ainda mais o clima de sobriedade. O cenário com o fundo também escuro complementa o tom quase monocromático do espetáculo.

A escolha pelo predomínio de uma tonalidade sóbria que percorre todo o espetáculo, desde cenário até figurino, implica uma diversidade de propostas. Primeiramente podemos inferir que a supressão de um leque de cores exerce a função de anular qualquer interferência externa, como se a cantora e os músicos estivessem nus, despidos de si próprios para incorporarem todas as referências ao mundo do samba que por eles perpassam. Pode-se notar também que a cor preta que reveste as roupas e o cenário remete ao ambiente noturno, espaço de criação e subversão dos sambistas entoados nos versos das canções. A noite é popularmente difundida como o cenário ideal de atuação dos sambistas e malandros, um ambiente que exerce um certo fascínio por ser a hora do dia que demarca a possibilidade de um movimento mais libertário, transgressor em relação às horas 
de claridade do dia, que diretamente se associam às funções pragmáticas do trabalho e do dever.

O malandro é geralmente visto como alguém cuja esperteza se efetiva em sua lábia sedutora e em sua habilidade para aplicar pequenos golpes. Pode ser também aquele que tem no samba um modo de discurso social. Este malandro é concebido em geral como uma espécie de porta voz dos setores populares da sociedade, com seu discurso repleto de ginga e seduções baratas. Sua indumentária sui generis o caracteriza como figura marcante, possuidora de um vestuário que pode ser visto como uma narrativa através da qual podemos ler e ver aspectos fundamentais do processo de construção de sua identidade social.

Moreira da Silva, o Kid Morengueira, foi um dos malandros mais famosos da história do samba, mais especificamente da modalidade samba de breque. Seu estilo indefectível de se vestir, com um terno de linho branco, sapato de duas cores e chapéu de panamá, à moda dos antigos malandros da Lapa, fazia dele quase que uma figura anacrônica nos tempos atuais. Essa impressão de anacronismo já veio tematizada de certa maneira na canção "Homenagem ao malandro", de Chico Buarque, que mostrava, com certo ar saudosista, a transformação pela qual começava a passar o verdadeiro malandro. Este malandro conhecido de velhos carnavais abandonou a navalha e passou a aderir a novos comportamentos; já começava no fundo a se transformar em matéria de memória:

Eu fui fazer um samba em homenagem

À nata da malandragem

Que conheço de outros carnavais

Eu fui à Lapa e perdi a viagem

Que aquela tal malandragem não existe mais (http://letras.mus.br/chicobuarque/45135/)

Quando se trata de descrever a figura do malandro, predomina a insistência em alguns traços que o descrevem, como a navalha no bolso, lenço no pescoço, chinelo charlote, etc. Há a criação de uma tipologia bem definida do personagem, tal como se delineia no imaginário popular e é representado nas letras dos sambas dos anos 30. Com o passar do tempo essa imagem é modificada e a elegância malandra é substituída pela forma caricatural do malandro engravatado. Em ambos os casos, o traje se assemelha a uma fantasia na medida em que articula componentes bastante típicos para criar um personagem, um tipo que foge aos padrões sociais ordinários, colocando-se à sua margem (MATOS, 1982, p.64). 
É notável como as representações acerca da figura do malandro, presentes nos vários discursos que abrangem a literatura, música, cinema e teatro, sugerem uma imagem de um personagem cujo modo de se vestir se confunde com suas próprias qualidades humanas. Dias Gomes e Ferreira Gullar, na peça “Dr. Getúlio, sua vida e sua glória” criam o personagem Simpatia, um misto de malandro, bicheiro e presidente de escola de samba que muito traz dessa imagem clássica

[...] veste calça de linho branco, uma camisa colorida, sapatos de duas cores. É um tipo sorridente, comunicativo, envolvente, como um camelô carioca. Quando não está "desfilando" de Getúlio é mais exuberante de gestos, mais "largado" no andar. Seu apelido define uma característica fundamental de sua personalidade: a simpatia algo malandra e irresistível. (GOMES e GULLAR, 1968, p.5,6)

Este malandro clássico descrito por Ferreira Gullar e Dias Gomes é revisitado por Calcanhotto em "Micróbio vivo", que consiste numa espécie de apologia ao universo do samba, com suas seduções e fetiches. O desenvolvimento performático da cantora, ao longo de todo o espetáculo, demonstra contínuas referências a esse malandro, um sujeito cheio de swing, gingas e humor elevado. A maneira como ela movimenta o seu corpo logo ao entrar no palco para interpretar "Eu vivo a sorrir", canção de abertura, mostra um diálogo com o desempenho repleto de malabarismos e gingas do clássico malandro. Calcanhotto simula tropeços, inclina um pouco o corpo para frente, aderindo ao jogo cênico da malandragem.

Esse retorno ao mundo do malandro é feito por meio de releituras que incorporam simultaneamente um ato de reverência e reelaboração crítica. "Dos prazeres, das canções”, música de Péricles Cavalcanti, é eleita com propriedade para deixar evidente a proposta do espetáculo. Esta canção é uma homenagem aos grandes compositores que revestem com sedução a aura malandra, a exemplo de Noel Rosa e Heitor dos Prazeres:

Eu sou aquele

Que o tempo não mudou

Embora outro, eu sou o mesmo

Eu sou um mero sucessor

A minha estirpe

Sempre esteve ao seu dispor

Me dê ouvidos que eu lhe digo quem eu sou

Sou Herivelto, sou Caymmi

Eu sou Sinhô

Eu sou Valente, eu sou Batista 
Eu sou Noel, eu sou Heitor

Dos prazeres, das canções

Eu sou doutor

Nos sentimentos de alegria e

de dor, dô, dô o que você quiser

Tô, tô, tô

Pro que der e vier ( In: CALCANHOTTO, 2011)

Esta canção é uma homenagem explícita aos destacáveis compositores que contribuíram para a criação e consolidação do gênero. Noel Rosa é um notável representante do estilo, com suas músicas que abordam o universo da malandragem centralizado na cidade do Rio de Janeiro. Herivelto Martins, Wilson Batista, Heitor dos Prazeres e Dorival Caymmi consistem também em compositores fundamentais que contribuíram para o enriquecimento do estilo. Felipe Trotta argumenta sobre a importância da tradição:

A tradição do samba (e em outros gêneros) se manifesta através da reverência a obras e compositores do passado, que se tornam representantes de um imaginário cujo eixo de valoração é a noção de continuidade, de permanência. Assim, um sambista adquire maior valor à medida que se demonstra mais próximo afetiva e esteticamente de símbolos desta tradição. (TROTTA, 2007, p.5)

Como afirma Trotta, a tradição do samba e dos demais gêneros se manifesta por meio da reverência a obras e compositores do passado. Calcanhotto, em "Micróbio vivo", continuamente revisita esse imaginário e traz para o centro da cena a "noção de continuidade", permanência. Tradição e modernidade se interligam em toda a concepção do espetáculo, na medida em que a sua elaboração se realiza através de diálogos, citações, desconstruções ou homenagens, como em "Esses moços”. Esta canção desponta através de uma homenagem repleta de delicadeza e lirismo, uma reverência a Lupicínio Rodrigues, compositor que motivou o título do cd e do espetáculo registrado em DVD. A artista interpreta o clássico "Esses moços" fazendo menção à tradição dos cantores do rádio ao pegar um microfone à moda dos antigos, que ficavam num pedestal em pé enquanto o cantor soltava sua voz de frente para ele. Calcanhotto subverte o modelo tradicional, caminhando com um microfone que alude ao estilo entre as mãos.

A figura do malandro é continuamente retomada em pequenos atos performáticos realizados pela artista. O universo da orgia, espaço aberto para o cometimento de atos "transgressores”, que incomodam-desestruturam o mundo 
ordenado e pragmático do trabalho e das obrigações, é revivenciado nas letras de algumas canções como "Vem ver". Nesta música, Calcanhotto incorpora a voz do malandro, que tenta se redimir diante da mulher prometendo abandonar todos os vícios. A figura do malandro está diretamente associada ao pólo da desordem; a malandragem consiste num sistema simbólico que se apresenta no campo da literatura, da música e das narrativas folclóricas como variações de um "mitohistória.

Em "Vem ver", Calcanhotto simula o comportamento do malandro que deseja se desligar do mundo da desordem, representado pela bebida. Ela pega um pequeno copo com água, dá uma golada e em seguida joga o restante do conteúdo fora aludindo a um copo de cachaça. O mundo da boemia é revisitado pela cantora numa postura cênica.

Por você tomava rumo

Arrumava o que fazer

Eu levantaria cedo

Eu deixava de beber

Vem cá, vem ver

Vem ver (In: CALCANHOTTO, 2011)

O malandro incorpora a fantasia do proletário, do negro, do oprimido encarnando a realização de certos anseios coletivos: não pega no batente, é temido pelos homens e desejado pelas mulheres. Vive sempre no lado oposto às obrigações e deveres, se delicia na orgia do samba, sem, contudo, perder a linha. De acordo com Cláudia Matos (MATOS: 1982) o malandro, com sua indumentária e seus modos sempre característicos e caricaturais, não deixa no fundo de ser um oprimido que permanece fantasiado o ano inteiro.

Calcanhotto reverencia esse malandro em "Dos prazeres, das canções", com uma emissão de voz que contrasta com o aspecto mais malemolente, presente na divisão dos sambistas. Ela imprime sua marca, sua assinatura rasurante na canção na medida em que segue numa interpretação que vai na contramão do estilo peculiar dos sambistas. Sua voz suave dá ênfase à nuance de cada nota, não há uma divisão rítmica caracteristicamente mais entrecortada, como se ouve na interpretação dos sambistas. A cantora imprime sua própria leitura, não intenciona reproduzir a maneira de cantar dos intérpretes do gênero. Por outro lado, suas atitudes gestuais remetem diretamente à postura cheia de "swing" do malandro. Ela pega o chapéu em cima da mesa a seu lado, mas não o coloca na cabeça. Este 
adereço configura uma menção à indumentária dos sambistas, a cantora incrementa a performance colocando o chapéu na frente de seu rosto, encobrindoo propositalmente para que a anulação da própria face dê lugar à exploração da memória abstrata do espectador.

O samba, desde o princípio do século $\mathrm{XX}$, constitui-se como um referencial de cultura para o Brasil. De 1930 até 1990, passou por um processo de releitura ou de reinvenção da tradição que culminou no desenvolvimento de subgêneros como samba de roda, samba enredo, samba de breque, samba canção, partido alto e pagode.

O samba de breque, por exemplo, é uma vertente do samba que explicita em seu estilo uma maneira de interpretar marcante. Ele traz como característica de seu modo interpretativo a pausa no acompanhamento acentuadamente sincopado, que visa a uma intervenção declamatória do intérprete. Estas paradas bruscas são denominadas breques, por influência do inglês break. Os breques são frases apenas faladas que imprimem graça e malandragem. Calcanhotto ao incorporar a figura do malandro em desempenhos performáticos que exploram essencialmente expressões corporais, não utiliza na voz nenhum recurso empregado no samba de breque. A divisão do canto da artista nada tem de semelhante à dos típicos intérpretes dessa modalidade, que mostram o enquadramento da voz que oscila entre intencionais rupturas e quebradas rítmicas.

A tonalidade predominantemente monocromática do espetáculo favorece a concentração na força dos elementos, em que toda a concepção estética e sonora se faz sob uma perspectiva concentrada, compacta, redutora. Trata-se da manifestação de um olhar enviesado da artista, que ao mesmo tempo em que debruça-se sobre o gênero samba em reverência, deseja transformá-lo. O trio musical que acompanha a cantora compõe um formato dissonante em relação à tradição do gênero, em que se destaca o predomínio de uma linguagem sonora experimental. Calcanhotto comenta sobre o desempenho musical do baterista e percussionista Domênico

Esse negócio do Micróbio especificamente, a condensação de idéias musicais dele. Esse negócio de virar o surdo da bateria, que é uma peça que fica assim, ele vira o negócio no chão, toca como se fosse um bumbo de bateria, mas é um surdo. O sete dele nesse show é uma loucura. (In: CALCANHOTTO, 2011) 
A cantora, ao falar sobre o conceito sonoro do músico Domênico, evidencia a opção deste por uma elaboração musical que se ergue sob o primado de uma condensação de ideias musicais. Essa condensação se faz na maneira como ele, através de poucos recursos instrumentais, extrai uma amplitude de sons, inverte e subverte a função dos acessórios da bateria e cria novas possibilidades que transcendem as vias do próprio instrumento. Nota-se que a proposta é criar uma riqueza rítmica que não se limite a um formato pré-determinado; há um movimento de constante renovação sonora que se edifica no intenso diálogo produzido entre a equipe de músicos. O aspecto performático se renova em riqueza expressiva, na medida em que Calcanhotto e os músicos se harmonizam numa sintonia unívoca que aspira sempre à descoberta de originais possibilidades sonoras

Eu aprendo muito com eles no sentido da coisa da espontaneidade musical. Porque tem um lado do meu trabalho que é tão movido por conceitos que em muitos momentos isso chegou a atrapalhar a fluidez musical, eu acho. (In: CALCANHOTTO, 2011)

A relação de intensa cumplicidade sonora entre a artista e os músicos é destacada tanto na atuação destes no palco, como fora. A convivência prolongada entre eles, principalmente nas turnês internacionais, favorece um processo de permanente diálogo e amadurecimento sonoro em que a música é objeto de inesgotável pesquisa. Torna-se interessante ressaltar que a própria Calcanhotto explicita a prevalência de uma verve conceitual em seu trabalho, que necessita muitas vezes ser diluída num processo espontâneo de comunhão musical. Entendemos a colocação da artista no sentido de que seu objetivo é criar uma arte que traga novos conceitos, mas que não se embaralhe por nenhum excesso de intelectualismo. O escopo da artista é que haja um desenvolvimento espontâneo, que não seja suprimido por teorias e conceituações. Há um pensar o samba que implica uma reflexão ampla sobre o gênero, tanto em termos estético-conceituais quanto sonoros. Sobressai uma retomada crítica de vários clichês que envolvem a história do estilo, mas tudo se faz por meio de uma linguagem que não se fixa no lugar comum ou na exaltação de estereótipos.

Calcanhotto dá sustentação à sua modalidade de pensamento de verve conceitual não somente no desempenho performático de seu corpo, mas também na maneira como manipula alguns instrumentos atípicos ao samba. Ela não toca 
instrumentos rítmicos comuns ao estilo, como pandeiro, tamborim ou cuíca; subverte o tradicional esquema rítmico do samba explorando novas possibilidades sonoras com objetos que não se dirigem objetivamente a uma finalidade musical. Na interpretação da música "Vai saber”, ela expressa uma acentuada marcação rítmica, fortalecida pelo uso de exóticos objetos que funcionam como adereços cênicos e instrumentos musicais. Calcanhotto reproduz o som de uma buzina com o intuito de produzir um "ruído", que intencionalmente exerce uma função subversiva em relação à concepção mais tradicional do samba.

O disco “Micróbio do samba” e o DVD “Micróbio vivo” não se enquadram inteiramente nos pressupostos que definem por exemplo o samba de raiz, realizado por artistas como Tereza Cristina, Arlindo Cruz e Beth Carvalho. Os instrumentos rítmicos usuais que compõem o estilo estão ausentes. Não há nenhuma espécie de exaltação rítmica em "Micróbio vivo" que o torne uma espécie de prolongamento da modalidade "samba de raiz". Até mesmo a presença de um baixo acústico soa bastante destoante em relação à configuração desta tradição musical. O samba de raiz é considerado uma das expressões mais autênticas da cultura musical brasileira, cujo o termo é geralmente empregado para se referir ao sambistas mais conservadores. Em um grupo de samba de raiz é habitual encontrar instrumentos como pandeiro de couro, cavaquinho, cuíca, surdo, violão, e violão de sete cordas. Em “Micróbio vivo”, a intenção dos músicos não é dar continuidade a um formato musical consolidado, e, sim, inoválo a partir da reestruturação dos elementos.

Calcanhotto, ao tentar se expressar sobre o aspecto sonoro singular de "Micróbio vivo", afirma que a sua performance e a dos demais músicos pode ser por certo prisma encarada como uma "antítese" do samba, por não obedecer ao formato tradicional. Não há por parte de toda a equipe do espetáculo nenhum intento de tentar fixar o trabalho sobre o rótulo de "samba renovado", ou algo do tipo. O que move e dá vigor a "Micróbio vivo" é seu caráter inovador, independente de qualquer classificação. A cantora define:

A gente vai assumir, é desse jeito que a gente vai tocar samba. É desse jeito que a gente toca. Não está querendo dizer com isso que o samba é assim, ou deva ser assim, mas esse é o jeito que a gente faz, com tudo o que a gente ouviu. É a nossa liga aqui. (In: CALCANHOTTO, 2011) 
Zeca Ligiéro, na obra “Corpo a corpo" (2011), analisa algumas performances do samba e argumenta que o gênero pode ser compreendido em quatro categorias distintas: "samba-brincadeira”, "samba-ritual”, "samba-drama” e "samba-épico". Segundo o estudioso, essas definições, utilizadas por ele para estudar as formas e funções dos sambas, foram delineadas pelos próprios sambistas das primeiras décadas do século XX a partir de suas próprias práticas, tanto no âmbito da composição musical, quanto da escolha temática. Dentre as quatro modalidades exemplificadas, o samba-drama consiste no mais significativo em relação à tradição comumente difundida pela música popular brasileira.

"Batucada da vida”, música de Ary Barroso e Luiz Peixoto, trata-se de um exemplo de "samba-drama". Nas composições de Ary o samba revela com virtuosidade seu estilo romântico em tempo rítmico lento. Esta canção, originalmente escrita para uma peça musical e cantada pela primeira vez por Araci Cortes, ganhou posteriormente gravações pungentes nas vozes de Carmem Miranda e Elis Regina. Ari Barroso, nesta composição em forma de monólogo, conta a história de uma mulher que passou sua vida na rua. Para a figura feminina explícita na letra o samba é fundamental, pois marca os únicos momentos felizes de sua vida

\author{
No dia em que eu apareci no mundo \\ Juntou uma porção de vagabundo \\ Da orgia \\ De noite teve samba e batucada \\ Que acabou de madrugada \\ Em grossa pancadaria \\ Depois do meu batismo de fumaça \\ Mamei um litro e meio de cachaça \\ Bem puxado \\ E fui adormecer como um despacho \\ Deitadinha no capacho \\ Na porta dos enjeitados [...] (LIGIÉRO, 2011, p.164)
}

Ari Barroso, em suas composições, põe em evidência a importância do samba para os desvalidos, marginalizados e excluídos da sociedade brasileira. Percebe-se que Calcanhotto, ao compor seus sambas, extrai grande parte de suas idéias desse imaginário rico e dramático presente nas criações de Ari e de outros sambistas. Torna-se interessante destacar que a cantora adapta sua elaboração da figura feminina aos tempos atuais: a mulher que assume a voz em seus sambas conduz o ritmo e a cadência de sua própria vida. Sendo assim, o olhar 
propositalmente distorcido da artista recria a canção em som e substância. Em “Tá na minha hora”, a figura feminina assume o próprio discurso, dona de si, expressa seus desejos e ações, em oposição à mulher que antes se submetia a lábia do malandro, nos velhos sambas.

Te fiz uns sambas, neguinho,
Te dei carinho
Despi as suas fantasias
Devagarinho
Da sua onipotência
Tratei com jeitinho
E das chegadas de madrugada
No sapatinho
Agora ta na minha hora
Eu vou passar uns tempos
Em Mangueira
Não chora,
Neguinho, não chora
O meu coração é da Estação Primeira
Te deixo a geladeira cheia
E sem promessa
Que findo o carnaval eu tô de volta
Não chora, neguinho não chora
Tá na minha hora
Tá na minha hora (In: CALCANHOTTO, 2011)
O próprio título da música já indica a sua intencional inversão de
stas: se a hora sempre foi dos homens e malandros, no histórico das
osições do samba, Calcanhotto dá voz à mulher, que, repleta de ironia,
dionisíaca.

A origem e significado da palavra carnaval apresenta duas versões, a primeira concede à palavra "carnaval” uma origem profundamente religiosa, com um sentido quase oposto ao da diversão, brincadeira. "Carnaval” tem sua origem no latim carnevale (carne + vale $=$ carne + adeus), e simbolizaria a "terça-feira gorda”, último dia do calendário cristão em que é permitido comer carne, dado que, no dia seguinte, inicia-se a quaresma. A segunda versão indica que a palavra carnaval vem de Carrus Navalis, por influência das festas em celebração e honra a Dionísio, deus do vinho e das orgias. Os ritos religiosos consagrados a Dionísio eram conhecidos como "mistérios dionisíacos," em que se bebia muito vinho para 
induzir transes que erradicavam inibições. As mulheres que participavam destes rituais executavam danças frenéticas que aproximavam suas atitudes à dos selvagens.

Três tipos de mulheres em geral figuram como imagens nas letras dos sambas tradicionais: a "doméstica”, a "piranha” e a "onírica”. A doméstica seria a mulher submissa e passiva, centrada no lar, a serviço do homem, que ordena as relações sociais e compõe o cotidiano. A mulher "piranha” é aquela de vida fácil, que satisfaz o homem em sua boemia, mas se caracteriza pela traição e por descontrolar e desorganizar as relações sociais. A mulher "onírica” representa uma mulher inexistente, construída por meio de expressões românticas. Esses três tipos de mulheres se misturam no imaginário da música popular brasileira constituindo faces de um mesmo quadro.

O paradigma da "mulher doméstica” pode ser representado pela música “Emília”, de Wilson Batista e Haroldo Lobo e “Ai que saudades da Amélia”, de Mário Lago e Ataulfo Alves:

\section{Emília}

Eu quero uma mulher Que saiba lavar e cozinhar Que, de manhã cedo Me acorde na hora de trabalhar Só existe uma E sem ela eu não vivo em paz Emília, Emília, Emília Eu não posso mais Ninguém sabe igual a ela Preparar o meu café Não desfazendo das outras, samba.html)

Emília é a mulher [...] (http://www.vagalume.com.br/haroldo-lobo/emilia-

Ai que saudades da Amélia

Nunca vi fazer tanta exigência

Nem fazer o que você me faz.

Você não sabe o que é consciência, Não vê que eu sou um pobre rapaz. Você só pensa em luxo e riqueza Tudo o que você vê, você quer. Ai, meu Deus, que saudades da Amélia Aquilo sim é que era mulher 
Às vezes passava fome ao meu lado

E achava bonito não ter o que comer.

E quando me via contrariado, dizia:

"meu filho, que se há de fazer?”

Amélia não tinha a menor vaidade

Amélia é que era mulher de verdade. (http://letras.mus.br/mario-lago/377002/)

Destaca-se nestes sambas clássicos o caráter doméstico das personagens, que se mostram submissas e passivas à figura masculina. São mulheres que simbolizam um aparato de segurança para o homem, mulheres que podem ser vistas também como uma espécie de encarnação da figura materna. Mulheres que, como mães, cuidam de seus homens. Estes padrões de mulheres descritos nas canções "Emília” e “Ai que saudades da Amélia” constituem seres excepcionais que estão ausentes; correspondem a um alto nível de exigência que dificilmente consegue ser correspondido.

A mulher ideal, portadora de um caráter submisso, talvez esteja pertencendo a um mundo idealizado, bem distante do universo nacional. A marchinha bem humorada "Deixa gueixa", de Calcanhotto, coloca em cena a figura feminina talvez ideal para o homem que deseja sempre ser servido. "Deixa gueixa” faz remissão ao estilo de composição das tradicionais marchinhas de carnaval, em que a cantora brinca com a imagem da gueixa através de um jogo de palavras. Os músicos repetem em coro os refrões retomando essa forma de entoar coletiva, que é uma das características presentes nas tradicionais interpretações. A artista imita o movimento de uma gueixa no andar e na inclinação do corpo, em que sobressai um toque de humor. Em "Deixa Gueixa”, a cantora retoma o estilo consagrado da marchinha, mantendo toda a integridade do seu modo de execução, não manifestando nesse sentido nenhuma intenção de subverter a forma original de tocar.

Em “Argumento", Calcanhotto e a banda elaboram uma releitura de uma das mais populares canções de Paulinho da Viola. A levada conduzida pela nova versão difere substancialmente do arranjo original, em que o compositor canta juntamente com uma base rítmica que obedece a um formato tradicional, enriquecido pelos instrumentos usuais do samba, como cavaquinho, tamborim, surdo e pandeiro. A formação da base sonora, recriada pelo trio constituído por Domênico, David e Alberto, privilegia uma levada que a principio muito difere do modo tradicional do samba. A canção é introduzida pela marcação do violão de 
Davi Moraes, que estabelece um diálogo com o contrabaixo tocado por Alberto e a bateria de Domênico, numa concepção sonora que faz lembrar as entradas de grupos de rock. A letra da canção de Paulinho da Viola tematiza a questão da “perda de identidade” do samba, que, naquele momento, já começava a sofrer a ameaça de descaracterização, sob a ótica dos mais conservadores, que não aceitavam que o gênero perdesse seus instrumentos substanciais, como cavaco, pandeiro e tamborim.

Tá legal, eu aceito o argumento

Mas não me altere o samba tanto assim

Olha que a rapaziada está sentindo a falta

De um cavaco, de um pandeiro ou de um tamborim

Sem preconceito nem mania de passado

Sem querer ficar do lado de quem não quer navegar

Faça como um velho marinheiro

Que durante o nevoeiro leva o barco devagar (In: CALCANHOTTO, 2011)

Calcanhotto e seus músicos optam pela exploração de novas ondas sonoras, navegando sem preconceito ou "mania de passado", como sabiamente recomenda Paulinho da Viola. A questão da discussão sobre a perda de identidade sonora não se restringe ao mundo do samba. Vale lembrar que a denominada "música popular brasileira”, em seu aspecto mais amplo, vinha sendo ameaçada de perder sua identidade com a invasão das guitarras elétricas na década de sessenta. Alguns artistas, manifestando uma visão mais conservadora, se opunham à entrada da guitarra na música brasileira, que, segundo eles, contribuiria para um processo de perda de identidade de nossas raízes nacionais, levando-nos para o caminho da massificação e americanização. O movimento anti-guitarra elétrica ganhou força tamanha pelos opositores, que chegou a resultar numa antológica passeata que ocorreu em 1967, em São Paulo. Liderada pela cantora Elis Regina, além de músicos como Jair Rodrigues, Zé Keti, Geraldo Vandré, Edu Lobo e até Gilberto Gil, essa passeata colocava em confronto um conflito entre tendências conservadoras e inovadoras. Sergio Cabral argumenta:

Eu hoje faço minha auto crítica, eu fiquei ao lado da passeata, que hoje vejo como uma coisa ridícula. Bobagem brigar contra a guitarra elétrica, é uma coisa idiota, bobagem. Mas nós nacionalistas, nós da esquerda achávamos que a música brasileira não podia ser invadida pelo que vinha de fora e a guitarra elétrica era o símbolo dessa invasão e tal.

(http://poesiampb.blogspot.com.br/2011/12/marcha contra guitarratropicalismo.html) 
Para Caetano Veloso, colocar uma guitarra elétrica numa música implicava uma decisão política, e o movimento contra a sua entrada a seu ver parecia um retrocesso. Num depoimento concedido décadas após o acontecimento da passeata, ele confirma sua postura absolutamente adversa ao que preconizavam os opositores da guitarra.

Eu fui contra, ficamos eu e a Nara no hotel Danúbio e comentando como isso era uma coisa estranha, terrível e que não deveria estar acontecendo. Aí o negócio passou pela rua e a Nara ficou assim, "eu tô deprimida, parece uma passeata fascista do partido integralista", e era exatamente o que parecia. Para mim era uma decisão política colocar uma guitarra elétrica numa música, fazer as canções com banda de rock, guitarra elétrica era uma atitude também política e diametralmente oposta à atitude da passeata contra as guitarras elétricas. (http://poesiampb.blogspot.com.br/2011/12/marcha-contraguitarratropicalismo.html)

Vê-se então que a escolha da música “Argumento" para compor o repertório de "Micróbio do samba” se encaixa com muita propriedade na proposta do espetáculo. Essa serve como uma espécie de auto-crítica do procedimento "inovador", adotado pela cantora e os músicos. Calcanhotto "leva o barco devagar”, introduzindo seu olhar renovador que revisita o gênero, trazendo experimentações. A letra da música de Paulinho da Viola serve como metáfora à crítica que um trabalho como "Micróbio vivo" poderia vir a receber através daqueles que só compreendem o samba executado por meio de seus instrumentos usuais. Não somente a substituição destes tradicionais instrumentos poderia vir a acarretar uma recepção não muito calorosa, mas a própria maneira de conceber os ritmos também poderia ocasionar alguma insatisfação àqueles mais conservadores.

Uma intenção performática mais acentuada, com nuances de experimentalismo sonoro se dá na interpretação de "Pode se remoer", executada em ritmo de balada. A letra traz a figura feminina como portadora do discurso, que expressa sua autonomia na vivência de um amor

Pode se remoer

Se penitenciar

Eu encontrei alguém

Que só pensa em beijar

Você não tem o que dizer

Você nem pode não gostar

Cê pode até se ajoelhar

Ele só pensa em me querer (In: CALCANHOTTO, 2011) 
O tema da vingança, que assoma em "Pode se remoer", foi tematizado ao longo de vários sambas-canções de Lupicínio Rodrigues, como "Nunca” e "Vingança", em que a mulher canta seu sentimento de desforra em relação ao homem. A expressão “dor de cotovelo" foi vastamente empregada para designar suas músicas que abordam muitas desventuras amorosas. Um dos temas recorrentes centraliza-se no amante revoltado que foi abandonado ou traído:

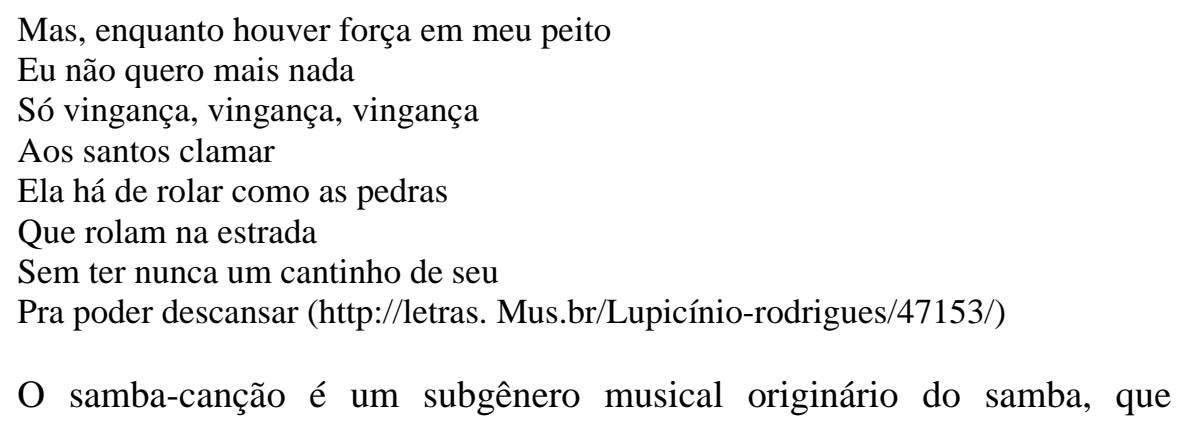
apareceu no final da década de 1920, no seio da modernização do samba urbano no Rio de Janeiro. Também denominado "samba de meio de ano", ele faz uma releitura mais elaborada na melodia, enfatizando-a, e possui um andamento moderado, focalizado em temáticas de amor, solidão e na chamada "dor de cotovelo”. O ambiente da década de 50 fomentou a expansão desse gênero no mercado nacional. Suas melodias eram marcadas por influências de gêneros musicais estrangeiros, como a balada de feitio norte-americano e o bolero cubano, especialmente enfatizado por orquestras. Suas letras eram quase sempre permeadas por um conteúdo pessimista, em que a melancolia era o tema mais destacado.

Além de Lupicínio Rodrigues, Herivelto Martins, Antônio Maria e Dolores Duran foram compositores que se destacaram no desempenho do tema amoroso abordado com intensidade nos sambas-canções. Dolores Duran pode ser considerada uma porta-voz especial e sensível das inquietudes e frustrações amorosas de seu tempo e lugar, conforme desenvolve Maria Izilda Santos de Matos na obra "Dolores Duran: experiências boêmias em Copacabana nos anos 50" (1997). Dolores cantava e compunha sobre as dores de amor e dos rompimentos, revelando suas experiências transcorridas nos bares e boates da Zona Sul do Rio de Janeiro. Suas composições faziam uso de uma linguagem coloquial que trazia como substrato poético a vida e seus dramas cotidianos. 
Juntamente com a dor, a culpa e a disponibilidade para o perdão, a solidão e a espera marcam a produção de Dolores Duran; em torno desses sentimentos circulam a saudade e a sensação de perda. A experiência da saudade tem dimensão espacial - uma distância no espaço - e temporal - a lembrança de um tempo feliz que foi perdido num tempo, mas mantido vivo na memória -, vinculando-se à nostalgia de um momento perdido de felicidade, com um certo tormento por ter deixado escapar um estado de felicidade. (MATOS, 1997, p. 93)

Dolores Duran exerce um papel fundamental no cancioneiro nacional, não somente pela qualidade de suas composições que trataram o tema amoroso inserindo uma coloqualidade incomum ao compositores que a precederam. Ela é uma espécie de precursora entre as compositoras femininas, pois, até então os homens predominavam, mesmo que trazendo como tema central de seus versos, questões muito particulares relativas ao universo feminino. Dolores aparece como uma possibilidade significativa de abertura para a entrada da mulher no reino da música popular brasileira enquanto compositora, mulher dona do discurso, e não objeto da alocução masculina. O ingresso da mulher na música sempre foi uma tentativa árdua, como declara Sueli Costa em entrevista a Ana Maria Bahiana. Sueli é uma das mais importantes compositoras brasileiras que despontou na década de setenta ao lado de Joyce, Angela Rô Rô, Fátima Guedes e Rita Lee:

Como é? Uma mulher compositora? Outros me achavam um bicho estranho. Queriam me fazer assim um produto exótico. Mulher compondo música é mesmo muito estranho. Não existe, não é? Não tem quase ninguém. Estranho isso. No começo me doía, me incomodava. Eu sentia, bem, que era tratada [...] sabe como é $[. .$.$] teve um cara aí de uma gravadora que queria me dar uns uísques [...] fazer$ uma transa [...] e depois ver se ia gravar [...] Essas coisas[...] eu estranhei no começo[...] fiquei quente de ódio. Mas é como a Joyce disse. 'Mulher não é considerada para nada. Vai ser considerada na música?’ E é uma coisa tão tola, no fundo.” (BAHIANA, 1980, P.221)

A partir do depoimento da compositora Sueli Costa, é possível dimensionar a dificuldade e importância da inserção da mulher na música popular brasileira. Um longo percurso se deu até que começasse de fato a se dissolver o preconceito agregado à figura feminina de destaque no cancioneiro nacional. A mulher, vista como objeto a mercê dos desejos masculinos, nas letras das canções, e impossibilitada de mostrar sua voz, com a tentativa de penetração no mundo dos compositores, era inicialmente tachada com atribuições negativas, associadas à leviandade e má conduta social. A expansão da figura da "compositora” na atualidade, em nossa música, se deve ao empenho exercido por estas antecessoras 
que ultrapassaram as barreiras do estigma e do preconceito. Calcanhotto surge no cenário musical brasileiro quando as portas para a entrada das mulheres compositoras já havia sido empurrada "à força” pelas artistas da geração anterior.

"Pode se remoer" põe em evidência o mote da vingança, em que a figura feminina revela toda a sua raiva dirigida ao seu homem, mostrando que é um ser capaz de recuperar sua auto-estima e dar a volta por cima. Esse tipo de mulher, que faz questão de deixar explícita nos versos das canções sua sedução e seu poder feminino, já foi entoado também em várias músicas por Chico Buarque. “Olhos nos olhos” é um exemplo que consagra a criação dessa mulher poderosa em sua essência feminina, que resgata por si própria sua auto-estima.

Quando você me deixou, meu bem,

Me disse pra ser feliz e passar bem.

Quis morrer de ciúme, quase enlouqueci,

Mas depois, como era de costume, obedeci.

Quando você me quiser rever

Já vai me encontrar refeita, pode crer.

Olhos nos olhos,

Quero ver o que você faz

Ao sentir que sem você eu passo bem demais

E que venho até remoçando,

Me pego cantando, sem mais, nem por quê.

Tantas águas rolaram,

Quantos homens me amaram

Bem mais e melhor que você [...] (http://letras.mus.br/chico-buarque/65962/)

Esta categoria de personagem feminina exaltada na canção de Chico Buarque, evolui em outras músicas do repertório do compositor. São mulheres que expressam uma tentativa ou consolidação de uma autonomia existencial e emocional que prescinde da existência da figura masculina, como revela por exemplo a prostituta em "Folhetim". Prevalece nesta mulher um jogo de dissimulação, dona de si ela vivencia a relação com o homem conforme seu próprio desejo, deixando-se “falsamente” se subjugar aos imperativos do macho.

Calcanhotto retoma o tema da "vingança" tão difundido por canções do gênero samba e outras, mostrando um diálogo com a tradição que se elabora por meio de constantes revisões. Em dado momento da interpretação de "Pode se remoer”, ela pega um secador de cabelos vermelho e se dirige até a estante com as partituras, ou letras das músicas, jogando-as lentamente no chão com o vento do 
aparelho de secar cabelos. Esta performance nos remete a uma outra, também com um certo objetivo "iconoclasta”, feita no espetáculo "Público", em que a artista, após ler um poema de Waly Salomão, "Remix século XX”, amassa todo o papel e joga-o para o público. A cantora canta um lirismo sob a constante ameaça crítica de dissolução; as folhas de papel caem sob a força do vento no espetáculo "Micróbio vivo" aludindo ao processo deglutidor exaltado nas vanguardas e nos "artistas de fronteira”, com o qual a cantora mostra estabelecer recorrentes conexões. Conforme Octávio Paz (1984), aquele que saber ser pertencente a uma tradição implicitamente já se sabe diferente dela, e esse saber encaminha-o cedo ou tarde a interrogá-la e muitas vezes até mesmo a negá-la:

[...] a modernidade é uma espécie de autodestruição criadora [...] O que distingue nossa modernidade das modernidades de outras épocas não é a aceleração do novo e surpreendente, embora isso também conte, mas o fato de ser uma ruptura:crítica do passado imediato, interrupção da continuidade. A arte não é apenas filha da idade crítica, mas é também crítica de si mesma. (PAZ, 1984, p.19,20)

Calcanhotto, numa espécie de subversiva revisão reverenciada ao passado, explicita um jogo que alterna as faces da construção e dissolução. No caso de “Micróbio vivo”, ela destaca essa duplicidade definida por Paz. A cantora retoma a tradição, mas sob seu olhar transfigurador que reposiciona e redimensiona as estruturas não fixas. Nota-se que o secador vermelho alude a uma arma, o vento que dele sai sugere novos caminhos para os textos que saem de sua posição estática na estante. Ao finalizar esta interpretação ela aponta o secador para cima, como se este fosse uma espécie de revólver. Luciano Alabarse, num texto dedicado a "Micróbio do samba”, discute a questão das propositais ambivalências presentes num disco que exalta um gênero rico em contrastes:

A notícia de que ela dedicaria ao samba um disco inteiro, uma safra inteira de novas composições, é surpreendente e maravilhosa. O samba brasileiro tem uma alegria melancólica, diferente da "alegria triste" da canção romântica brasileira; tem uma evanescência transgressora, uma força pulsante incomparável. O samba é o ritmo mais livre e, por isso mesmo, mais perigoso, reino propício à experimentações instrumentais, o gênero que melhor conjuga tradição e ruptura, qualquer que seja o nível de recepção que emprestemos a ele. Não é por nada que ocupa o espaço que ocupa na história brasileira. Raízes e antenas são os ingredientes de um samba a ser composto no século XXI. Há algo absurdamente vivo e que sempre acontece ao ouvirmos um samba bom. Aprendemos, de forma quase concomitante à audição, letra e música. Queremos ouvir novamente, e mais uma vez e outra mais, até que aquela canção esteja em nossos corações e corpos, nos levando a gingar e mexer pés e quadris, mesmo os mais reticentes e 
comportados ouvintes. Os espanhóis têm uma expressão especial para falar de seus artistas importantes, dizendo que os verdadeiros criadores artísticos devem estar possuídos por “duende”. No Brasil, os verdadeiros sambistas cunharam uma expressão extraordinária para reconhecer aqueles que importam e fazem a diferença, ao afirmar que os mesmos devem ter o "micróbio do samba" contaminando sua criação. É uma expressão surgida durante a década de quarenta, imortalizada em uma canção de Braguinha, gravada por nomes seminais da história do samba brasileiro. (www.adrianacalcanhotto.com.br)

Alabarse coloca em questão alguns pontos por nós problematizados ao longo de nossa reflexão sobre "Micróbio vivo" e "Micróbio do samba”, de Calcanhotto. Como enfatiza o crítico, o samba consiste num reino propício a experimentações instrumentais, e nesse sentido a artista e seus músicos ousam nas performances musicais que retomam o gênero samba, mas de um modo transmudado que visa inserir a assinatura rasurante da voz da cantora e seu olhar propositalmente "enviesado" sob os pilares da tradição.

\section{1}

\section{Performance em Partimpim 1, 2 e 3}

Realizar trabalhos qualitativos dedicados ao universo infantil não é tarefa fácil. No setor da música nacional o que mais se verifica é a ausência de seriedade e compromisso daqueles que se aventuram a adentrar na linguagem das crianças. Grande parte das produções musicais destinadas ao mundo infantil primam pela infantilização exacerbada, em que o potencial da criança é subestimado. Verificase abundantemente um processo de erotização precoce, de certa maneira estimulado pelas performances de artistas que transferem para a criança comportamentos que dizem respeito aos adultos. A cantora, compositora e instrumentista Adriana Calcanhotto, ao se transformar em Partimpim, mergulha com propriedade, delicadeza e sabedoria na natureza das crianças, sem se deixar comprometer por apelos reducionistas impostos pelo sistema mercadológico. A existência do exótico heterônimo Partimpim, se deu por reapropriação desse apelido adquirido na infância, quando, aos três anos de idade, diante do pai, Calcanhotto não conseguiu pronunciar “corretamente” as sílabas de seu nome, optando pela recriação mágica e sonora: Partimpim. Adriana Calcanhotto deslocou-se de si tal como Fernando Pessoa, com seus desdobramentos realizados nas criações únicas de Álvaro de Campos, Alberto Caeiro e Ricardo Reis. 
A primeira vez que eu lembro de ter tido a idéia de fazer um disco para criança foi em 94, dez anos de trabalho, de pensamento sobre esse disco. Em 99 eu tinha um repertório, comecei a gravar. E essa primeira idéia sempre foi de abrir uma possibilidade na minha vida para fazer discos infantis, não era um projeto. Esse que estou lançando agora é como se fosse o volume um, dentro dessa característica que eles têm. Se vão ser mais barulhentos, mais engraçados, mais lúdicos, não sei. A coisa do heterônimo foi acontecendo durante o projeto, nasceu da idéia de fazer música para criança que eu acho que é um território meio vago, indefinido aonde eu acho que cabe quase qualquer coisa e isso é bom, ao invés de ser mal. A produção do disco tem a seguinte senha para todas as pessoas: é um disco para criança. Mesmo que não deseje ser exatamente um disco só para crianças, pois eu acho que determinar o público é chato, não tenho vontade de dizer que a minha música é para pretos, é para pobres, é para crianças, é para gays [...] Eu acho que a recepção, dizer que é um disco para crianças abre o coração das pessoas para ouvir aquilo de uma forma que se eu não dissesse, eu não propusesse, a recepção poderia ser diferente. Essa é a coisa mais bacana. Um truque que eu vou usar para sempre, com Adriana Calcanhotto, com quantas eu for. (http://www.youtube.com/watch?v=EUKZ2okmoyM)

Partimpim é uma espécie de máscara-disfarce criada por Calcanhotto, que brinca com sua identidade num jogo de aparências. De acordo com Nietzsche, a aparência ocupa, no centro da cultura e do mundo gregos, um lugar primordial, fundador. Para eles esta poderia ser entendida como o princípio positivo, motor, o “princípio de todos os princípios”. Conforme o filósofo, os gregos não se apegavam às aparências por fraqueza, por impotência de não atingir a profundidade; ao contrário, justamente por serem demasiadamente profundos é que decidiram permanecer na superfície das coisas. Essa "superficialidade” se exercia por excesso, não por falta, visto que, após terem experimentado os impasses e sofreguidões da profundidade, a vivência da superficialidade surgia como uma opção consciente. A superficialidade desponta para os gregos como um redobramento, uma conclusão de sua profundidade. Esta superficialidade problematizada por Nietzsche em relação aos gregos, explicita um mecanismo de impedimento da profundidade,

uma profundidade que tem consciência de seus limites. Portanto ela nasce e vive num estado de tensão permanente: é mesmo porque existe nela simultaneamente a cada momento uma tentação e um combate contra a profundidade, que ela pode criar uma visão nova, renovada, do mundo. Seu valor reside nesse movimento contraditório, contrariado: é o recuo crítico que essa ambivalência fundamental introduz no olhar, que o aguça e o aprofunda e lhe abre uma visão mais rica e mais sutil das coisas. Fazendo com que ele saia do quadro estreito e realmente falso da explicação do mundo por "essências” a priori, por ideais, esse recuo obriga o nascimento de um novo olhar, mais sutil, mais diferenciado, mais penetrante [...] (BOLLON,1993, p.172) 
A superficialidade evocada por Nietzsche demonstra seu reconhecimento de que o mundo só poderá ser totalmente percebido, apreendido, para além da razão, ou seja, por outros meios, como a emoção estética. Os gregos concebiam a vida como uma arte, e essa arte lhes dava uma abertura para um conhecimento superior, mais substancialmente profundo do mundo. Calcanhotto, ao inventar sua máscara "Partimpim", expande suas possibilidades criativas, pois, através da criação dessa nova persona, abre a possibilidade para a exploração de novos recursos, que se ampliam para questões estéticas e sonoras. Conforme diz a cantora numa entrevista, essa mudança identitária tomou força principalmente quando ela deparou com uma citação do pintor Matisse:

[...] ele ficou fascinado quando descobriu que os artistas japoneses do Grande Período - na maioria gravuristas - tinham várias identidades, a que chamavam seus go. Diz que o sucesso é uma prisão e que o artista jamais deve ser prisioneiro de si mesmo, do seu estilo ou do sucesso. Neste caso, trata-se de um heterônimo porque há uma diferença no trabalho, no enfoque, na forma, no resultado. Gosto da idéia de, quando se começa um trabalho novo, zerar. O zero absoluto não existe mas gosto, de certa forma, da idéia de você se esvaziar e de não se encarar sequer como artista. Desligar-se do passado de alguma forma. (www.adrianacalcanhotto.com.br)

Partimpim é uma criação absolutamente independente de Calcanhotto em todos os aspectos: figurino, cenário, concepção sonora. Todo o universo estético, sonoro e visual são concebidos numa outra perspectiva, que visa aguçar prioritariamente a recepção das crianças. Sobressai um forte apelo ao caráter lúdico, divertido da criação, que se efetua por meio da busca de uma linguagem artística que prima pela idéia de "espontaneidade”. Mesmo que a realização do trabalho seja o resultado de um processo de muita reflexão, ensaios e experimentações, há o objetivo de deixar em destaque a espontaneidade da criação, como se Partimpim fosse uma menina sem idade, solta no tempo e no espaço, aberta para vivenciar a todo instante novas experiências, aventuras sonoras múltiplas e plenas de lirismo e diversão:

Minha idéia de fazer um disco para crianças era um pouco como o sentimento que Picasso e Miró tinham: quanto mais você faz uma coisa menos você sabe. O objetivo é saber cada dia menos sobre o que você faz até o ponto que se faça isso de uma forma infantil no sentido da espontaneidade, da falta de coerência. (www.adrianacalcanhotto.com.br) 
A inventividade é a marca maior que desponta em Partimpim; repleta de humor e lirismo, a artista brinca com as palavras, jogos e formas. O primeiro cd, "Partimpim", causou estimável impacto de público e crítica, aos olhos acostumados às performances de Adriana Calcanhotto. A nova Adriana Partimpim invade a cena com elementos originais e inusitados. Brincar é a ordem expressa pela artista que subverte, colore, mascara, revela, desvela, transcende em todas as formas imagináveis e inimagináveis. Conforme argumenta Fayga Ostrower, a criação implica basicamente em formar, ou seja, dar uma forma a algo novo. $\mathrm{O}$ ato criador abrange a capacidade de compreender e esta, por sua vez, de relacionar, ordenar, configurar, significar. Desde as primeiras culturas, o ser humano aparece dotado de um dom singular; ele é por essência um ser formador, apto a estabelecer relacionamentos entre os diversos eventos que ocorrem ao seu redor e dentro dele. Estabelecendo relações entre os eventos, ele os configura em sua experiência do viver e lhes imprime um significado. Em seus questionamentos, indagações ou nas soluções que encontra, ao agir, ao imaginar, ao sonhar, sempre o homem relaciona e forma:

\begin{abstract}
As formas de percepção não são gratuitas nem os relacionamentos se estabelecem ao acaso. Ainda que talvez a lógica de seu desdobramento nos escape, sentimos perfeitamente que há um nexo. Sentimos, também, que de certo modo somos nós o ponto focal de referência, pois ao relacionarmos os fenômenos nós os ligamos entre si e os vinculamos a nós mesmos. Sem nos darmos conta, nós os orientamos de acordo com expectativas, desejos, medos, e sobretudo de acordo com uma atitude do nosso ser mais íntimo, uma ordenação interior. (OSTROWER, s/d p.9)
\end{abstract}

Como esclarece Fayga, em cada ato do indivíduo, transparece a projeção de sua ordem interior. Esta consiste numa maneira específica de focalizar e de interpretar os fenômenos, sempre em busca de significados. Nesta busca de ordenações e de significados é que reside a profunda motivação humana de criar. Os processos de criação ocorrem no âmbito da intuição. Todas as experiências que acometem o indivíduo, inclusive as racionais, tratam-se de processos essencialmente intuitivos. As múltiplas opções e decisões que surgem no trabalho, e que implicam a configuração em vias de ser criada, não se limitam a operações dirigidas pelo conhecimento consciente. Estes processos na verdade são intuitivos e se tornam conscientes na medida em que são expressos, ou seja, na medida em que lhes damos uma forma. 
A percepção de si mesmo dentro do agir é um dado relevante que distingue a criatividade humana. Impulsionado por necessidades concretas sempre inovadoras, o potencial criador do homem surge na história como um fator de realização e constante transformação. Ele interfere no mundo físico, na própria condição humana e nos contextos culturais. $\mathrm{O}$ ato criador não existe destituído de um ato intencional: em toda a criação humana revelam-se certos critérios que foram construídos pelo indivíduo por meio de suas escolhas e alternativas. Fayga esclarece que somente perante um ato intencional, isto é, ante a ação de um ser consciente, faz sentido falar-se de criação.

Torna-se importante frisar que o potencial consciente e sensível de cada indivíduo se realiza sempre e exclusivamente dentro de formas culturais. Não existe possibilidade para o ser humano de que um desenvolvimento biológico aconteça independente de um desenvolvimento cultural. O comportamento de cada ser humano se molda pelos padrões culturais, históricos, do grupo em que ele, indivíduo nasce e cresce. Vinculado aos padrões coletivos, ele se desenvolverá enquanto individualidade incorporando a ela muito do que foi aprendido em sua convivência coletiva. Seu modo de agir, seus sonhos, suas aspirações e suas realizações estão diretamente associadas a todo o conhecimento adquirido em suas relações sociais e culturais.

Partimpim resgata a espontaneidade da criação infantil, sem contudo cair no pieguismo e em estratégias aliciadoras que subestimam a capacidade das crianças, transformando-as em objetos reprodutores de comportamentos adultos. Em "Partimpim” ,Partimpim2” e "Partimpim3” a cantora extrai e valoriza as potencialidades do universo criativo das crianças, utilizando sonoridades experimentais retiradas de brinquedos como apitos, chocalhos e bolas: "A Partimpim carrega objetos, ela gosta de acúmulo, guarda coisas. Ela guardou todos os bilhetes e brinquedos que ganhou das crianças, é o oposto da Calcanhotto" (www.adrianacalcanhotto.com.br).

Há que se notar que, apesar da artista trabalhar com elementos eminentemente pertencentes ao imaginário infantil, seus três álbuns infantis transcendem os rótulos que os enquadrariam estritamente no setor destinado às crianças; são discos feitos para todos os públicos: adultos e crianças. Sobre "Partimpim2”, a artista declara: 
A meta principal era não fazer o álbum soar como um disco infantil. Música para criança que aborrece os adultos é na verdade uma música aborrecida. E acho que na realidade as crianças ouvem o que está no mundo adulto: na TV, no rádio, na internet, no carro. Muitas vezes elas elegem coisas que não foram pensadas por elas (www.adrianacalcanhotto.com.br).

Quando nos referimos ao tratamento dado pelos adultos ao universo infantil, deve-se frisar que um dos problemas mais evidentes é a questão do aculturamento da criança. O que mais se constata é a presença de freios e imposições que limitam as possibilidades inerentes a ela. O adulto distanciado de sua essência criativa conduz a criança também à perda de suas potencialidades. Há um contínuo choque entre a expressão dos desejos das crianças e a recepção dos adultos. Sobretudo no que diz respeito aos brinquedos elaborados para satisfazer os anseios infantis, nota-se que há pouco espaço para a evasão criativa dos pequenos. Os brinquedos cumprem um papel de reprodução das fórmulas e conceitos do mundo adulto: os próprios pais se encarregam de ensinar aos filhos a maneira de brincar com bonecas e carrinhos, que já chegam às mãos delas com instruções pré-determinadas. A criança, ao sofrer inconscientemente a pressão do adulto, começa a moldar sua realidade inteiramente determinada por sua ordenação.

Estimular um refinamento da sensibilidade da criança é um exercício que cabe aos adultos, que exercem continuamente a função de lançar padrões comportamentais. Muitos estudiosos reconhecem a ocorrência de uma atrofia da sensibilidade em decorrência da queda de estímulos que movimentem o universo infantil. Herbert Read defende a idéia da educação construída pela via da arte, chamando a atenção para a necessidade de um desenvolvimento sistemático das qualidades e capacidades sensoriais de um indivíduo ao longo de sua vida, uma arma contra o processo de desumanização.

Se a visão e a habilidade manual, o tato e a audição, e todos os refinamentos da sensação que se desenvolveram historicamente na conquista da natureza e na manipulação das substâncias materiais, não forem educados e treinados desde o nascimento até a maturidade, o resultado é um ser que dificilmente mereceria ser chamado de humano: um autômato de olhos embotados, desinteressado e desatento, cujo único desejo é a violência, sob várias de suas formas - ação violenta, sons violentos, distrações de qualquer tipo que possam penetrar até seus nervos amortecidos. Suas diversões preferidas são: a arena de esportes, as casas de jogos mecânicos do tipo caça-níqueis, as discotecas, a indiferença ante o crime cometido à sua frente, a farsa e o sadismo na televisão, o jogo e as drogas. (HEAD, 1983, p.26) 
Torna-se fundamental, a qualquer obra artística que ambicione alcançar o universo da criança e tocar a qualidade de sua potencialidade emotiva, a existência de uma intenção de dizer "com verdade” o que pretende, jamais trazendo em sua linguagem excesso de puerilidade. A obra de arte deve ser o lugar em que a verdade se revela de maneira concreta, presentificando-se nos elementos sensíveis que lhe dão corpo. Um disco dedicado às crianças, assim como um livro, deve trabalhar a sua sensibilidade, seja em relação às formas de lidar com a linguagem, seja nos aspectos imaginativos presentes no universo representado pela obra.

Deve-se refletir que sobre as potencialidades humanas sempre incidem aspectos culturais. A cultura estabelece prioridades visto que o contexto cultural em que se forma a personalidade da criança, implicitamente, orienta e em muitos casos chega a propor as formas como devem ser desenvolvidas as modalidades de relacionamento. Muitas atribuições negativas ao desenvolvimento da criança se devem ao estabelecimento de uma hierarquia de valores estabelecida pela cultura. São as imposições culturais que determinam os tipos de relacionamento que impulsionam a formulação de abstrações e conceitos. Nos contextos culturais mais primitivos o homem se vinculava à vida por meio de um enfoque predominantemente sensual - afetivo. Havia um simbolismo que tentava dar conta de explicar a existência, sem o uso de conceitos de ordem mais racional e lógica. No decorrer do desenvolvimento histórico da humanidade a racionalização e a conceituação foram ocupando o lugar de uma antiga percepção mais intuitiva. Como salienta Fayga, parece que, na cultura em que vivemos atualmente, inexiste a experiência sensorial para o homem. Só se consideram como "válidos" e "reais" os relacionamentos que conduzem a definições e conceituações. Isso, de acordo com a educadora, pode ser visto no aculturamento da criança, nos brinquedos que lhe são oferecidos, objetivando a

uma retenção mecânica de fórmulas e conceitos, ou métodos de instrução preparando os jovens para participarem de atividades produtivas sociais, cujo aprendizado permanece largamente teórico (mesmo nas áreas técnicas). Não existe quase nenhum contato com matérias, com processos de trabalho, com pessoas. O conhecer reduziu-se a um saber, e o saber, a um teorizar. A compreensão sensível das coisas, integrando experiência e inteligência parece ter sido abolida. Com todo apreço, por exemplo, que se dá a certas obras de arte, despreza-se em verdade o que na forma artística existe de essencial: a condensação poética da existência como via de conhecimento da realidade. Não seria por acaso que, hoje em dia, as palavras poético, lírico, possam surgir até com conotações pejorativas, como visões desligadas da realidade do viver. Desde 
que não conceituam nem racionalizam, não abrangem a racionalidade do homem. De fato, o que não condiz com o "racional” como está sendo entendido por nossa sociedade, um racional mesquinho e calculista, de interesses pessoais e imediatistas, de pronto é tachado como sendo apenas "irracional" ou até mesmo inútil. (OSTROWER, s/d, p.86)

Como define Fayga, a ausência de valorização da experiência sensível do homem demonstra o desinteresse pelo próprio ser humano, com sua afetividade e potencialidades criativas. Conforme a ótica da educadora, sobressai um "clima alienante” na sociedade que faz suplantar os impulsos criativos no indivíduo. Sendo assim, resgatar a infância é de certa forma uma tentativa de recuperar esse elo perdido com nossas estruturas emocionais. É trazer à tona a valorização de uma pulsão criativa massacrada pelo predomínio de uma ordem tecnicista e fria.

Walter Benjamin realizou diversos escritos sobre brinquedos e livros infantis, nos quais registra suas histórias e configurações no decorrer do desenvolvimento industrial e pós-industrial. Ele faz referência a museus de brinquedos, locais onde encontram-se outros brinquedos clássicos, como os soldadinhos de chumbo e bonecas de porcelana, objetos na época já em processo de "esquecimento", conforme argumenta o autor. Torna-se importante mencionar que, nas fronteiras dos brinquedos, vão aparecendo, no séc XIX, os primeiros instrumentos de diversões que apresentam traços da virtualidade referidos por Benjamin:

Ainda mais profundamente do que por teatro de marionetes, somos introduzidos aos mistérios do mundo lúdico pelas câmaras ópticas, pelos dioramas, mirioramas e panoramas, cujas imagens eram confeccionadas em sua maioria na cidade de Ausburgo. "Já não se tem mais isto", ouve-se com frequência o adulto dizer ao avistar brinquedos antigos. Na maior parte das vezes isso é mera impressão dele, já que se tornou indiferente a essas mesmas coisas que por todo canto chama a atenção da criança (BENJAMIN, 2002, p.84).

Benjamin elabora um entrelaçamento entre a imagem e o lúdico, apontando um prenúncio da evolução e transformação que o brinquedo iria sofrer com o passar do tempo. $\mathrm{O}$ autor dirige sua atenção sobretudo para as modificações ocorridas com os brinquedos em relação ao universo virtual. Na Europa, inicialmente construídos em pequenas oficinas, os brinquedos de madeira, estanho e outros materiais eram confeccionados a partir de especificidades que se diferenciavam na perspectiva das formas e materiais utilizados. O filósofo aponta que a partir do século XIX começa a ocorrer uma transformação na forma dos 
brinquedos, que deixam de ser miniaturas. Quanto mais avança o processo de industrialização, mais o brinquedo vai sofrendo um distanciamento de seu caráter doméstico, abandonando sua inserção no contexto familiar. Essa transformação do brinquedo resultante do desenvolvimento industrial, marca o distanciamento entre as crianças e seus pais, que antes produziam juntos. O filósofo defende que os objetos que possibilitam à criança o contato, a construção e a desconstrução, descobertos nos mais insólitos lugares, produzem mais prazer a ela do que os brinquedos plastificados que podemos ver hoje em abundância no mercado.

Benjamin, em "Brinquedos e jogos, analisa a questão da repetição, que consiste numa característica intrínseca ao ato de brincar. A repetição, o "mais uma vez” é o fato que aguça na criança o desejo de brincar. Para ela duas vezes não são suficientes para esgotar uma brincadeira, faz-se necessário repetir sempre de novo, centenas, milhares de vezes. A essência do brincar está em sua contínua repetição, no "fazer sempre de novo". O adulto, ao narrar uma experiência, alivia o seu coração dos horrores, goza duplamente uma felicidade, como define o filósofo. Já a criança volta a inventar para si todo o fato vivido, retoma o novamente do início. A essência do brincar está então nesse "fazer sempre de novo”, a transformação da experiência mais surpreendente em hábito.

Pois é o jogo, e nada mais, que dá a luz a todo hábito. Comer, dormir, vestir-se, lavar-se devem ser inculcados no pequeno irrequieto de maneira lúdica, com o acompanhamento do ritmo de versinhos. O hábito entra na vida como brincadeira, e nele, mesmo em suas formas mais enrijecidas, sobrevive até o final um restinho da brincadeira. Formas petrificadas e irreconhecíveis de nossa primeira felicidade, de nosso primeiro terror, eis o que são os hábitos (BENJAMIN, 2002, p.102).

Torna-se importante salientar que o comportamento das crianças evolui essencialmente por um procedimento mimético, é olhando e imitando atitudes alheias que a criança cria o seu próprio mundo. Benjamin, em "A doutrina das semelhanças”, discorre sobre o tema, ao mencionar que a questão da apropriação mimética provém da própria natureza que engendra semelhanças, a exemplo da mímica. De acordo com o filósofo, o homem possui a capacidade suprema de produzir semelhanças, e todas as suas funções superiores são co determinadas pela faculdade mimética. As brincadeiras infantis representam com propriedade a predominância do caráter mimético. O mundo da percepção infantil está impregnado por toda parte pelos vestígios da geração mais velha e nesse sentido é 
impossível construir uma infância ou arte pura, que esteja isenta de toda a carga de informações que a precedem. Segundo Benjamin, o brinquedo, mesmo quando não imita os instrumentos dos adultos, é confronto, e, na verdade, mais dos adultos com a criança:

Pois quem senão o adulto fornece primeiramente à criança os seus brinquedos? E embora reste a ela aceitar ou recusar as coisas, não poucos dos mais antigos brinquedos (bola, arco, roda de penas, pipa) terão sido de certa forma impostos à criança como objetos de culto, os quais só mais tarde, e certamente graças à força da imaginação infantil, transformam-se em brinquedos. (BENJAMIN, 2002, p.96)

Nas crianças, a criatividade se manifesta em todo o seu fazer solto, espontâneo, imaginativo, no sonhar, no simbolizar, no associar. A criança, em seu ato de brincar, elabora uma relação de fingimento com a realidade, que na verdade constitui o seu próprio real. Para ela, criar significa viver. É comum observar a impulsividade na criança: ela age espontaneamente para ver o que acontece. A produtividade infantil é rica em diversidade e descoberta. O que pode significar para os adultos uma experiência audaciosa, arriscada, para a criança implica apenas o seu vivenciar natural da situação.

As mudanças no comportamento da criança e suas formas de expressão não são decorrentes de transformações exclusivamente de índole estética. Devemse ao seu processo de crescimento e desenvolvimento, às suas relações afetivas consigo própria e com o mundo adulto, e a sua evolução para níveis de independência interior. As alterações que aparecem na expressividade infantil correspondem a suas fases de crescimento físico e psíquico. À medida que a criança vai se autodesvelando, estabelecendo-se dentro de si e em relação aos outros, também reestrutura seu potencial sensível e racional em níveis mais complexos. A partir dessas transformações muda-se a própria relação da criança com a realidade, sua convivência, solicitações e formas de comunicação. Conforme argumenta Fayga, entende-se que a criação infantil pode ser estimulada. A forma como se visa ao incentivo do potencial infantil, reflete-se nos objetivos e nos comportamentos desejáveis estabelecidos para a criança. Vale lembrar que a criatividade infantil é uma espécie de semente que contém em si tudo o que o adulto vai realizar.

Na criança, o criar está em todo o seu viver e agir; é desta maneira que ela toma contato com o mundo e transforma a si mesma. Mesmo que suas ações 
afetem o ambiente, ela não o faz intencionalmente, pois tudo o que faz é em função da necessidade de seu próprio crescimento, de sua busca de realização. Já o adulto criativo impõe alterações no mundo que o cerca, em suas atividades produtivas ele usualmente acrescenta sempre algo em termos de informação e formação:

Nessa sua atuação consciente e intencional, ele pode até transformar os referenciais da cultura em que se baseiam as ordenações que faz e aos quais se reportam os significados de sua ação" (FAYGA, s/d, p.130).

A criatividade se faz em conjunto com a realização da personalidade de um ser, em que a maturação é um processo vital para a criação. Com sua maturidade, o indivíduo criará espontaneamente, irá executar a criatividade como função global e expressiva da vida.

Mais do que tempo externo, a maturidade exige um tempo interno. O tempo necessário, relativo em cada caso, para que certas potencialidades, talentos, capacidades, interesses, possam elaborar-se intelectual e emocionalmente - para que se elaborem num desdobramento total do indivíduo e de um modo tão intimamente ligado ao seu ser, que o indivíduo faça da própria elaboração e do desdobramento uma experiência vital que integre, ampliando-a, a visão que nele se forma do mundo e da vida. Não há tempo cronológico para esse desenvolvimento. Pode dar-se rapidamente e também pode ser lento. O importante, sempre, é que se dê o processo. (FAYGA, s/d, p.131)

Como define Fayga, o amadurecimento não é refém dos limites de expansão. O que mais vale é o processo criador compreendido como um percurso contínuo no homem comum, não somente nos considerados artistas. O poder criador do ser está em sua capacidade ordenadora e configuradora, sua sensibilidade para captar em cada momento vivido a unicidade da experiência e relacioná-la a outros momentos. Os percursos criativos consistem em processos construtivos globais que envolvem toda a personalidade e a maneira do indivíduo singularizar-se e relacionar-se com os outros. O indivíduo, no seu processo progressivo de amadurecimento, se diferencia dentro de si, e em níveis mais complexos, se reordena e reorienta em seus componentes diferenciados. O processo de maturação, como explicita a educadora, envolve uma "unificação em maior diversificação", implica a busca de uma identidade possível na “individuação da personalidade”. Crescer, realizar potencialidades e definir uma identidade consistem em anseios inerentes ao indivíduo. 
Partimpim leva o humor para o centro da cena, pois é consciente de que a criança é um ser que se constrói através do exercício de variadas formas de humor. Desde o balbuciar das primeiras sílabas, ela experimenta formas divertidas, engraçadas e inesperadas de sons. Ainda destituída da ordem do discurso imposto pelo pragmatismo lógico do mundo adulto, este pequeno ser ousa na invenção de seu próprio discurso em que as palavras valem por si mesmas, em suas qualidades estéticas inatas. Para Jacqueline Held

Há mil formas de humor, nas quais a criança estará mais ou menos cedo, dependendo de seu caráter, de seu modo de vida e, sobretudo, sem dúvida, de sua educação. Uma coisa é certa: é pela brincadeira, por sua disponibilidade inicial que a criança definida por numerosos psicólogos como sendo, antes de tudo, e por excelência, “um ser que brinca”, entrará no humor. (HELD,1980, p.180)

A criança evoluirá com a construção e revelação de seu senso de humor, de acordo com a vivência que adquire e as situações que lhe são propostas. Este germe poderá crescer ou atrofiar-se. Ela elabora o seu próprio jogo e tenta fazer com que o adulto também faça parte desse mundo fabuloso. O humor é sobretudo a manifestação de um senso de proteção, uma forma com que a criança tenta lidar com seus desejos e frustrações.

O humor se realiza com maestria nos três trabalhos de Calcanhotto dedicados à criança. Este aspecto lúdico se sobressai principalmente através da maneira como ela brinca com vários animais, como o leão, a formiga, a tartaruga, o peixe, a gatinha, o passarinho, o pato e a borboleta. Seguindo a linhagem de Vinícius de Moraes, que em “A arca de Noé” realizou uma ode poética aos bichos contemplados com humor e delicadeza, a artista canta os animais com intimidade e descontração. A história da Arca de Noé, conforme os capítulos seis a nove do livro do Gênesis, inicia-se com Deus observando o mau comportamento da humanidade e disposto a inundar a terra e destruir toda vida. No entanto, ele encontrou um bom homem, Noé, que ficou encarregado de levar para uma arca dois exemplares de cada espécie animal, macho e fêmea, visando assegurar a sobrevivência e preservação das castas recolhidas. Noé, sua família e os animais que entraram na arca foram as únicas criaturas que conseguiram sobreviver a um imenso dilúvio.

Os discos “Arca de Noé 1” e “Arca de Noé2” reúnem os poemas musicados do livro “Arca de Noé”, escrito por Vinícius de Moraes. Paulo 
Soledade e Toquinho musicaram a maior parte deles, como "O Pinguim”, “O porquinho”, “O peru”, “A formiga” e "A galinha d'angola”. O lirismo do formato poético ganha força sonora com as composições musicais, que em sua maior parte acentuam o lado engraçado e bem - humorado dos versos, que exploram a graciosidade e simultânea falta de compostura dos animais:

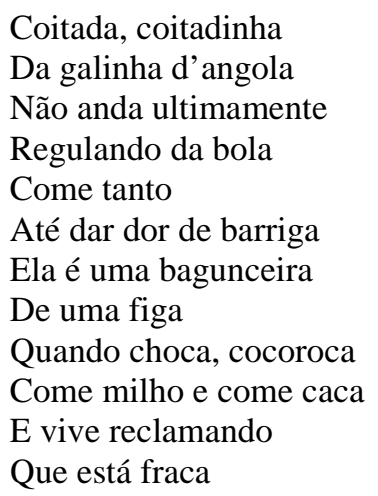

A interpretação desta música dá destaque a uma levada cheia de swing, que põe em evidência o humor presente nos versos do poeta. A performance de Ney Matogrosso ressalta em seu enquadramento rítmico a intenção lúdica da música. É uma rumba abarrotada de swing, que traz a participação das crianças em pequenas entradas no formato de coro. Há um brincar com a sonoridade das palavras, no entoar dos versos que intencionam reproduzir de modo irônico o som produzido pela galinha. O cantor repete várias vezes o refrão "Tou fraca! Tou fraca”, que remete à sonoridade emanada pelo animal, justamente este o momento maior de comunhão com o universo infantil, como se neste trocadilho sonoro estivesse o convite para a criança tomar parte da brincadeira musical. "O peru", interpretado pela cantora Elba Ramalho, evidencia a mesma proposta líricosonora, em que os versos da canção, em sua evidência lúdica, mostram a intenção de brincar com o próprio som sugerido pela pronúncia das palavras em cadência rítmica. Numa levada de forró, a música contempla a participação das crianças no coro de vozes.

Glu! Glu! Glu!

Abram alas pro peru!

Glu! Glu! Glu!

Abram alas pro peru! 
O peru foi a passeio

Pensando que era pavão

Tico-tico riu-se tanto

Que morreu de congestão

O peru dança de roda

Numa roda de carvão

Quando acaba fica tonto

De quase cair no chão ( In: MORAES, 1981)

Nesta canção, assim como em “A galinha d'Angola”, sobressai uma intenção lúdica, um brincar com a sonoridade dos versos e com os compassos rítmicos. O balanço é convidativo à participação da criança, que se diverte com as experiências sonoras fornecidas pelo jogo de palavras. Estes tipos de composição caem bem principalmente para aqueles que estão iniciando o processo de alfabetização, reconhecendo a produção sonora dos encontros vocálicos e da segmentação das sílabas. A palavra cantada é objeto de um experimentalismo lúdico. Octávio Paz afirma que, na poesia, “a unidade da frase, o que a constitui como tal e forma a linguagem, não é o sentido ou direção significativa, mas o ritmo"” (PAZ, 1982, p.61). O ritmo constitui a ordem que junta e separa as palavras espontaneamente, que comanda as afinidades e as repulsas. Se o homem é capaz de reproduzir esse ritmo, ele possui o poder sobre as palavras. A reprodução se efetua por meio da métrica, da aliteração, da rima, da assonância e de outros processos rítmicos. A poeticidade presente em “A arca de Noé” realiza esta proposição, apontando que o ritmo é um agente de sedução e que, em sua utilização, realiza-se a criação poética. A aliteração, que consiste na repetição de fonemas para produzir efeitos, é um recurso poético frequentemente evidenciado nos versos de Vinícius. O poeta brinca com a aliteração do "P” em "O pato":

Lá vem o Pato

Pata aqui, pata acolá

Lá vem o Pato

Para ver o que é que há

O Pato pateta

Pintou o caneco

Surrou a galinha

Bateu no marreco

Pulou do poleiro

No pé do cavalo

Levou um coice

Criou um galo

[...] Tantas fez o moço

Que foi pra panela (In: MORAES, 1981) 
Os versos demonstram as inquietações de um bicho, que se movimenta de um lado para o outro, sempre criando confusão. O jeito desengonçado do pato, que se perde em situações conflituosas com vários animais, acaba acarretando seu fim trágico, a panela. Nota-se que as canções de “A arca de Noé” criam relações humanizadas entre os bichos. A brincadeira acontece todo o tempo e sempre de maneira divertida. O poeta dá uma dimensão amplificada ao mito bíblico ao mesmo tempo que o recompõe, utilizando-se de elementos naturais, humanos e brasileiramente líricos para manter seu vigor poético.

O dado destacável nos dois álbuns de “A arca de Noé” é o fato de que há um exclusivo intérprete para cada canção, favorecendo assim uma riqueza e amplitude de propostas interpretativas. Jane Duboc, Grande Otelo, Elis Regina, Marina Lima, Clara Nunes e Paulinho da Viola são alguns dos artistas que imprimem suas versões singulares para as músicas. Nota-se que o substrato poético jamais se perde em nenhuma das interpretações, a palavra e o som se harmonizam em concepções sonoras que exploram ora um lirismo mais acentuado, como quer "Corujinha”, na voz da cantora Elis Regina, ora um humor elegante, como mostra "O Pinguim”, na voz de Toquinho. Os diminutivos, que também consagram o modo de composição dos versos do poeta, possibilitam a aproximação da criança com seu próprio universo de miniaturas, como se tudo estivesse apreensível, ao seu alcance.

Pintinho novo
Pintinho tonto
Não estás no ponto
Volta pro ovo
Eu não me calo
Falo de novo
Não banque o galo
O meu ovo ta estreitinho
Já me sinto um galetinho
Já posso sair sozinho [...] (In:MORAES, 1981)

Quando se produz um poema, uma canção ou uma história dedicada à criança, deve-se levar em conta a relevância do aspecto vocabular e as construções sintáticas que devem estar em consonância com este tipo de público. Os elementos estruturais do texto, aliados aos elementos poéticos e lúdicos, devem necessariamente estar presentes, fazendo com que aflore na criança a sua 
sensibilidade, criatividade, fantasia e emoção. O exercício com a poesia deve ser feito a partir da ampliação da capacidade do pequeno ser em sentir os elementos que nela são capazes de lhe transmitir emoção. $\mathrm{O}$ apuro estético deve ser uma das questões a não ser negligenciada. Segundo Abramovich, a poesia para crianças,

assim como a prosa, tem que ser antes de tudo, muito boa! De primeiríssima qualidade! Bela, movente, cutucante, nova, surpreendente, bem escrita [...] Mexendo com a emoção, com as sensações, com os poros, mostrando algo de especial ou que passaria despercebido, invertendo a forma usual de a gente se aproximar de alguém ou de alguma coisa [...] Prazerosa, triste, sofrente, se for a intenção do autor [...] Prazerosa, gostosa, lúdica, brincante, se for a intenção do autor (ABRAMOVICH, 1989, p. 67).

Como define Abramovich, a poesia dedicada à criança deve possuir em sua essência um caráter sedutor, que se destaca no tratamento singular concebido à linguagem. Cabe ao autor um senso apurado no que diz respeito ao desvelar da inventividade, que deve ser a linha condutora da obra. Torna-se fundamental uma escolha minuciosa do vocabulário e da forma como este deve ser disposto visualmente, dado que grande parte das crianças estão sendo iniciadas no processo da escrita e leitura, e só tomam contato com a linguagem poética por meio da visualização e da história contada por um adulto. Ao adentrarmos no universo da canção, devemos aplicar o mesmo apuro lírico e estético, pois a criança é tocada fortemente por apelos sonoros e visuais que lhe despertam a vontade de participar de maneira interativa com a arte que lhe é oferecida. A artista declara a importância adquirida pelo legado deixado por compositores da estatura de Villa Lobos, Chico Buarque e Tom Jobim, que realizaram trabalhos também dedicados às crianças:

\footnotetext{
Minha principal inspiração vem de algo que eu sempre considerei muito generoso, que é o fato dos monstros da música brasileira, como Heitor Villa Lobos, Chico Buarque e Vinícius de Moraes sempre terem feito coisas para crianças. Quando eu era criança, eu ouvia o Vinícius de Moraes cantando e sentia que aquilo era diferente dos disquinhos que eu tinha. Eu não sabia que a diferença era a poesia. Então mesmo sem saber o nome, as crianças e os adultos percebem a diferença. (www.adrianacalcanhotto.com.br)

Como diz Calcanhotto, a existência do substrato poético presente nos trabalhos de Vinícius de Moraes, Chico Buarque e Villa Lobos é o que acrescenta o grande diferencial em relação aos demais voltados para o universo infantil. É o
} 
tratamento lírico dado à matéria, mesmo que “infantil”, que é responsável pelo acabamento que toca a sensibilidade com mais apuro.

Partimpim traz o alinho estético e lírico prenunciado por Abramovich. O DVD que mostra o registro visual e sonoro da apresentação do repertório de seu primeiro CD elucida a primazia da valorização estética. A personagem Partimpim surge no palco magicamente, como vinda dos contos de fadas, tal qual a criação de Walt Disney, Mary Poppins, com sua sombrinha encantada. A cantora desce do alto do céu e aterriza no solo cênico, alicerçada por balões azuis que desempenham o papel de asas. O impacto da elaboração performática, que coloca Partimpim como um ser quase etéreo, é resultado do trabalho da artista e sua equipe junto ao grupo de teatro A intrépida Trupe, que auxiliou no desenvolvimento corporal da cantora em seu processo de adaptação a linguagem de índole circense, representada pelo uso de recursos que expandem as possibilidades de movimentação do corpo. A intrépida Trupe é um grupo quase inteiramente formado pela Escola Nacional de Circo, cujas performances misturam teatro e dança, com o humor de palhaços em números acrobáticos. Suas criações trazem o signo da coletividade, em que os atores-acrobatas dão seus passos na investigação de uma linguagem oriunda de múltiplas técnicas e referências. Uma espécie de extensa gangorra manipulada pelo grupo remete ao universo infantil. Partimpim assentada nesta gangorra despede-se do palco, como se alçasse vôo rumo ao infinito.

Muitas cores invadem o cenário revestido de instrumentos coloridos e brinquedos diversos, no qual o que mais importa é dar vazão à liberdade criativa. A personagem Partimpim traz em si um forte apelo visual: o grande óculosmáscara rosa que encobrem seus olhos, no momento de abertura do show, revelam mais um complemento à intenção multicromática do espetáculo. Seu casaco com estampa florida mistura o lúdico ao kitsch, e os tênis calçados em cores alternadas dão um sentido carnavalizante a figura criada por Calcanhotto. Partimpim parece não ter idade, uma mistura de menina, boneca, criança e mulher. Essa sua nãodelimitação cronológica favorece ainda mais a interatividade com o universo infantil, visto que as crianças se colocam em sintonia com este personagem que fala a mesma língua, habita o mesmo planeta de sonhos e fantasias delas. Paulo Roberto Pires, no release intitulado "Brincadeira de gente grande”, da temporada de estréia do espetáculo Partimpim, descreve: 
No show, "infância" tem a ver com o frescor e a simplicidade com que Adriana e os quatro músicos que a acompanham executam arranjos cheios de sutilezas e humor. Se o músico de jazz parece sempre estar trabalhando e astros de rock aproximam-se muitas vezes de um ritual ou transe, na terra de "Partimpim" todos eles estão, o tempo todo, brincando, com sorriso e cumplicidade que se costuma deixar de lado na chamada "vida adulta"[...] No fundo, todo artista é parente próximo da criança ao reinventar o mundo em sons, palavras e imagens [...] A criança que Adriana Calcanhotto busca neste show é a que vai dançar na platéia e, também, a que está em tudo o que é simples e, justamente por isso, complexo. Leveza conquistada em um árduo trabalho de depuração, "Partimpim" é a melhor prova de que brincar de criança é coisa de gente grande (www.adrianacalcanhotto.com.br)

Nota-se a existência de uma diversidade de instrumentos musicais, em que o experimentalismo sonoro constitui uma das bases condutoras da perspectiva lúdica da apresentação. Guilherme, músico encarregado da maior parte da produção sonora rítmico-percussiva, toca uma bateria de latas construída por ele próprio, que traz em seu conjunto uma bacia, pratos quebrados, reco reco, e um pedaço de uma peça de uma máquina de lavar. Dé Palmeira, músico que toca algumas modalidades de contrabaixo, executa também um inusitado instrumento criado pelo maestro Walter Smetak, suíço que viveu no Brasil e, por aqui, influenciou significativamente o tropicalismo em geral e Gilberto Gil em particular. Smetak compunha, dava aulas e criava instrumentos. A partir de suas anotações relativas aos seus instrumentos inovadores publicadas, Dé Palmeira construiu o "Pistom cretino”, invenção feita com o uso de um bocal de trompete, uma mangueira de plástico e um funil de cozinha. Estes três elementos ligados produzem um som semelhante ao de um trompete com surdina.

Partimpim toca algumas variedades de guitarras e o violão, seu instrumento inseparável. O prato tocado por ela, na "Canção da falsa tartaruga", faz remissão ao instrumento usado no recôncavo da Bahia, comumente executado com o auxílio de uma faca para produzir ritmo nos tradicionais sambas de roda. Edith Oliveira Nogueira, mais conhecida como Dona Edith do Prato, ficou nacionalmente consagrada por utilizar como instrumentos musicais uma faca e um prato. Ela cantava sambas de roda em Santo Amaro da Purificação, sua terra natal, explorando sonoridades desses objetos retirados do universo doméstico. Como revela Ninho Nascimento, produtor musical e seu neto de criação,

Ela começava a tirar os primeiros sons da metade de uma cuia de queijo quando brincava de fazer comida no quintal de casa. Na adolescência, tocava prato e assim descobriu um som diferente e foi aperfeiçoando. Para ela, o prato tinha 
que ser de louça e o mais barato, e a faca de inox, sem cabo de madeira. Não teve referência artística, mas um dom, que foi desenvolvendo aos poucos. Ela nunca se imaginou artista. (http://pt.wikipedia.org/wiki/Dona_Edith_do_Prato)

Partimpim troca a faca por uma colher, pois o instrumento por ela executado alude ao prato servido para tomar uma sopa, tema da canção. O experimentalismo sonoro, que consiste numa das práticas de Calcanhotto, é retomado com intensidade nas criações executadas pela Partimpim. O mundo de vastos e inovadores sons produzidos no espetáculo se concretiza por meio da experiência com sons extraídos dos mais variados objetos, como um sapo de brinquedo, celular de plástico vendido em camelô, caixinhas de música, lixas de pedreiro, tampas de garrafas pet, entre outros. O uso de várias caixinhas de música ao mesmo tempo revelam a intenção de produzir um efeito aleatório, um anti-som, como define Partimpim:

Caixinhas de música que eu uso no final da Ciranda da Bailarina, a idéia é que elas todas tocando juntas façam uma música nenhuma. Uma música que seja atonal, que seja uma música não definida. São musiquinhas típicas de caixinha de música, mas quando tocam todas juntas se faz uma música esquisita. (In: CALCANHOTTO, 2010)

A música atonal contrapõe-se à música modal pelo fato de possuir uma ausência absoluta de uma nota central, que na música modal determina a possibilidade de uma sequência de notas que a seguem na música. Esta ausência total de uma nota central impulsiona a sensação de um certo sentimento de “confusão” e “aleatoriedade”, dado a tendência de compreendermos a música dentro de um sistema modal e tonal. Na música atonal não existem acordes maiores ou menores, nem escalas. A atonalidade não atingiu a música popular com a mesma intensidade que a erudita, mas é possível perceber sua influência em grandes compositores do século XX, como Miles Davis e John Coltraine. No Brasil o músico Arrigo Barnabé trouxe experimentos atonais em seus discos “Clara Crocodilo” e “Tubarões Voadores”.

Partimpim, ao colocar simultaneamente várias caixinhas de som para tocar, mostra seu objetivo de produzir um som embolado, pouco audível, por isso então uma espécie de anti-som. O show mostra a todo o tempo os diálogos que estabelece com uma produção musical mais alinhada na vertente da vanguarda. Há uma fusão entre uma diversidade de elementos sonoros que trilham caminhos 
experimentais. A artista aproveita a liberdade da proposta lúdica do espetáculo para adentrar no universo dos sons. É brincando que se toca simultaneamente diversas caixinhas de música, chocalhos japoneses, apitos, tampas de garrafas, água, entre tantas invenções. A profusão de experimentações sonoras realizadas pela Partimpim e seus músicos, nos permite uma associação com um dos maiores inventores da música popular brasileira, o plurissonoro Hermeto Paschoal. Este compositor, arranjador e multi-instrumentista participou da gravação da música de Calcanhotto "Uma canção por acaso”, executando seu piano a convite da própria. O legado de Hermeto transparece em vários momentos do show Partimpim, principalmente no instante em que a cantora produz um som com o bater das palmas das mãos sob um recipiente cheio de água. O objeto criado pelo cenógrafo Helio Eichbauer consiste num enorme caldeirão arredondado em forma de bacia transparente, que comporta dentro uma considerável quantidade de água. A água enquanto possibilidade rítmica foi vastamente experimentada pelo mago dos sons. O ouvido absoluto e infalível de Hermeto é o guia em suas composições musicais. Multi-instrumentista e um improvisador virtuoso, ele, com sua vastidão sonora, mostrou que num mesmo solo se podia alternar tocando instrumentos como o piano elétrico, teclados eletrônicos, escaleta, instrumentos de sopro e percussão, às vezes utilizando dois instrumentos simultâneamente e, ainda, a voz. A música, para este criador, é um veículo transcendental que o une à natureza e aos animais, aos demais seres humanos e até mesmo aos seres das hierarquias espirituais. Sendo assim, para o "bruxo” Hermeto, a música consiste num ritual. Por meio do ritual musical a experiência espiritual e estética se interligam, de forma inseparável. Adentrar na música deste vasto bruxo dos sons implica uma tentativa de tentar decifrar o enigma de seu programa artístico e de seus mecanismos de sentido. Qualquer composição sua traz o signo da surpresa, do novo, do surpreendente. Em todos os seus temas os ouvintes encontram elementos sonoros e musicais que normalmente ali não deveriam estar, que habitualmente não se escutam em outros compositores.

Na música de Hermeto Paschoal a prevalência da mistura de sons favorece fortes contrastes, timbres contrastantes, variações marcantes de andamento, densidades distintas e graves mudanças entre as partes de suas composições. Sua atração pelo novo é a mola propulsora de todos os seus movimentos sonoros, os “hermetismos Paschoais”, como diz Caetano Veloso em “Podres poderes”. 
Partimpim, em sua salada de experimentações sonoras, deixa em evidência a influência exercida por Hermeto Paschoal, o inventor e manipulador dos sons em sua pluralidade. É utilizando-se da perspectiva amplificada do caráter experimental, possibilitada pelo modo lúdico do conceito musical concebido pela artista, que se revela o amplo espaço concedido à experimentação musical.

A cantora Fernanda Takai e sua banda, a exemplo de Partimpim, também ousa na inventividade sonora voltada para o universo infantil. No álbum "Música de brinquedo", os músicos explicitam uma radical experiência com texturas musicais, visto que não utilizam quase nenhum instrumento convencional. $\mathrm{O}$ disco foi todo gravado com instrumentos de brinquedo ou miniaturas, com o auxílio de instrumentos relacionados à musicalização infantil, como flauta, xilofone, kalimba e escaleta. O projeto traz canções conhecidas do público adulto executadas apenas com instrumentos de brinquedo, como "Frevo mulher" (Zé Ramalho), Sonífera ilha (Titãs) e Live and let die (Beatles). Embora Fernanda Takai não crie nenhum heterônimo para se transportar para o universo infantil, assemelha-se a Partimpim no sentido de elaborar um projeto musical que também se expande para todos os públicos. Crianças e adultos são o alvo da artista:

Queríamos que o disco não tivesse só uma camada de entendimento e graça. Era importante que todas as idades se divertissem com a sonoridade e a identificação do adultos fosse pelo lado emocional do repertório, claro. Buscamos canções que a gente mesmo gostava muito e com certeza mexesse com a memória afetiva de todos. As crianças se identificaram com as vozes das crianças que cantam de um jeito bem natural. No show temos os monstros cantando com a voz natural de monstro... (http://blog.opovo.com.br/discografia/fernanda-takai-comentasobre-o-show-musica-de-brinquedo-amanha-em-fortaleza/)

"Música de brinquedo" é mais um trabalho diferencial no sentido de que imprime a marca da qualidade ao produto final, sem se restringir a um público específico, como o das crianças por exemplo. A utilização de instrumentos inusitados, improvisados pelo próprio grupo, possibilita interpretações que escapam do lugar comum. A cantora e os músicos mostram ousadia e inventividade ao elaborarem releituras de um repertório já difundido pelo grande público nacional e internacional. Live and let die, dos Beatles, perde o ar predominantemente rock and roll e ganha nuances experimentais. Vozes de crianças se misturam com sons de pianinhos e teclados de brinquedo. Há uma proposital estridência na interpretação que visa justamente a mostrar seu ponto 
contrastante. Sendo contemporânea de Partimpim, Fernanda Takai é uma artista que, neste trabalho mais direcionado para o público infantil, opta também pela verve mais experimental que dá vazão ao lúdico.

“Na massa”, composição de Davi Moraes e Arnaldo Antunes, interpretada pela Partimpim no álbum "Partimpim2”, recebe um arranjo que realça as múltiplas nuances inventivas presentes tanto no experimentalismo sonoro, quanto nos versos de Arnaldo Antunes. A artista usa e abusa de recursos lúdicos, como pianinhos de brinquedo, programações de bateria e sons aleatórios. A letra da canção propõe o reinado da liberdade criativa, em que as crianças se jogam livres de regras, imposições e métodos cerceadores. É o momento de confeccionar os próprios figurinos sem obedecer a modas, rasgar e descolorir tecidos, subverter todas as regras e impor o império da invenção infinita. Vale se sujar de tinta, estragar o penteado do cabelo, perder o eixo de direção, pois as direções são inúmeras e inesgotáveis:

\author{
Pode ser de farda ou fralda \\ Arrastando o véu da cauda \\ Jóia de bijuteria \\ Lantejoula e purpurina \\ Manto de garrafa Pet \\ Tatuagem de chiclete \\ De coroa ou de cocar \\ Pode se misturar \\ Na massa \\ Some na massa \\ Pode vir de esporte ou gala \\ De uniforme com medalha \\ Braço cheio de pacote \\ Nada debaixo do short \\ Derramando seu decote \\ Gargantilha no cangote \\ Segue a moda de ninguém \\ Usa o que lhe convém (In: CALCANHOTTO, 2009)
}

"Na massa” abre espaço para a expressão criativa das crianças. Plena de humor e descontração, essa música se encaixa com eficácia no projeto lúdico de Partimpim. Ela tematiza o imaginário criador infantil, mas sem ser exatamente uma canção que se restringe a um repertório estritamente infantil, haja vista que Arnaldo Antunes a gravou em cd de sua autoria e com arranjo totalmente distinto. Ela é uma espécie de make yourself, em que as crianças confeccionam seus figurinos com absoluta autonomia. Desponta dos versos uma profusão de sons 
anarquicamente aleatórios, que se alternam na condução da base musical. Partimpim chama os pequenos para participarem de seu encontro festivo, um grande "ágape” lúdico que vai se configurando numa enorme e difusa "massa", composta de muitas propostas diversificadas. Os versos do compositor incorporam diferentes idéias, cores, formas, transformações e dissoluções, explicitando seu olhar que capta o potencial criativo pertencente às crianças. Em depoimento à cineasta Helena Solberg no filme "Palavra Encantada", Arnaldo Antunes diz:

Eu sempre fui fascinado pela coisa do olhar infantil em relação às coisas do mundo, a maneira de fazer associações inusitadas, de ver coisas que muitas vezes são óbvias, mas são tão óbvias que a gente não repara. É como se desse a volta e o óbvio passa a ser estranho, acaba criando um estranhamento pelo fato de você se tocar de que não havia reparado que aquilo é assim, e é assim todo dia, mas você não vê dessa forma. $E$ as crianças, muitas vezes, ensinam a ver de um jeito muito virgem. O Oswald de Andrade tem um poema maravilhoso que diz: "Aprendi com meu filho de dez anos que a poesia é a descoberta das coisas que eu nunca vi”. (In: SOLBERG, 2009)

Nesta declaração, ele mostra a importância do papel desempenhando pelo artista, no sentido de trazer de volta, por meio de sua criação, a poesia que se perdeu nos recônditos da infância. A criança e o artista se aproximam na medida em que ambos transitam num território vasto e infinito de descobertas e experiências. Esse olhar "virginal”, apontado pelo músico, é o aspecto singular inerente à criança e permanentemente buscado por qualquer criador, seja na instância musical, plástica seja na literária. Alcançar a pureza da percepção inaugural é uma conquista que se faz através de um exercício depurado e muitas vezes árduo, batalhado pelo criador.

“Na massa” consiste então na apologia desse universo amplo de possibilidades criativas exaltado pela artista transfigurada em Partimpim. Gaston Bachelard, em sua obra “A poética do devaneio”(1988), dedicou um capítulo aos devaneios voltados para a infância, no qual defende a existência de uma infância eterna, componente da alma humana. Segundo o filósofo, sobretudo os artistas são propensos à manutenção de um inquebrável laço com a infância:

[...] a infância, soma das insignificâncias do ser humano, tem um significado fenomenológico próprio, um significado fenomenológico puro porque está sob o signo do maravilhamento" (BACHELARD, 1988, p.122). 
Essa constatação abre duas grandes visões: a infância como lugar privilegiado, fonte das primeiras percepções intuitivas, única para cada ser humano, e como condição universal por excelência. Uma espécie de "primeiridade", evidenciada no olhar puro da criança, vem imbuída de alumbramentos, marcando seus sentidos ainda não totalmente condicionados pela educação. Sobressai no pequeno ser sua visão anterior a conceitos, guiada pela curiosidade de penetrar o mundo que se oferece inesgotável a sua sede de descobertas. O devaneio presente em toda infância é revelado pelo filósofo como um par de asas, um instrumento privilegiado para explorar a realidade. Bachelard define esse estado como a gênese da capacidade de imaginar, sendo esta compreendida como uma faculdade complementar da razão. Essas "asas" permitem a criança dar combustível a um comportamento exploratório, que lhe permite transcender além dos limites culturais estabelecidos pela lógica, onde tudo é liberdade. O universo da criação artística pode ser então compreendido como um campo de receptividade privilegiado para a expansividade da imaginação. Sendo assim, conforme a reflexão desenvolvida pelo filósofo, o puro exercício da imaginação presente na infância encontra seu espaço de receptividade e expressão no campo artístico.

Voltamos a problematizar a questão da presença dos animais nos trabalhos dedicados ao universo infantil, visto que eles compõem e habitam o mundo da criança na condição privilegiada de receptáculo aberto para o devaneio. Ela esbalda-se com o jogo festivo das palavras em que uma riqueza de construções sonoras e imagéticas, guiam um universo complexo de implicações. Os animais não figuram apenas nos poemas e canções consagrados ao universo infantil; estão presentes sobretudo nas fábulas e narrativas orais da antiguidade. As fábulas consistem em composições literárias cujos personagens são geralmente animais, forças da natureza, ou objetos que revelam características humanas, tais como a fala, os costumes, etc. Estas histórias em sua grande parte são realizadas para crianças e se encerram sempre com um ensinamento moral de caráter instrutivo. A fábula é um gênero narrativo surgido no Oriente, quando era usual se propagar um conjunto de pequenas histórias de caráter moral em que os protagonistas eram os animais. Por meio do diálogo entre os bichos e as muitas peripécias pelas quais eles passavam, procurava-se transmitir ao homem uma sabedoria de caráter moral em que os animais consistiam em exemplos comportamentais. Cada animal 
simboliza algum aspecto ou qualidade do ser humano na fábula: o leão representa a força, a raposa a astúcia e a formiga o trabalho.

As fábulas, portanto, são um quadro onde cada um de nós se acha descrito. O que elas nos apresentam confirma os conhecimentos hauridos em virtude da experiência pelas pessoas idosas e ensina às crianças o que convém que elas saibam. E como estas são recém chegadas neste mundo, não devemos deixá-las nessa ignorância senão durante o menor tempo possível. Elas têm que saber o que é um leão, o que é uma raposa, e assim por diante, portanto às vezes se compara o homem a um destes animais. Para isto servem as fábulas, pois é delas que provêm as primeiras noções desses fatos. (LA FONTAINE, V.I, p.39)

As fábulas sempre exerceram atração nas crianças por lidarem com o imaginário infantil, através do uso de personagens antropomorfizados, ou seja, com sentimentos humanos. Entretanto participam da dimensão simbólica que corresponde ao funcionamento mental da criança. Além de estimular o imaginário infantil através da relação afetiva e projetiva que a criança estabelece com os personagens, elas também oferecem elementos e situações de aprendizado sutis que se exprimem através de exemplos permeados de moral. Há uma função educativa conferida a essa categoria de texto que influencia na distinção entre bem e mal, certo e errado, justo e injusto. As fábulas, por serem uma forma mais popular de narrativa, se ajustam com facilidade a várias culturas e visões de mundo.

Na literatura brasileira, Monteiro Lobato é um autor significativo que retoma a genealogia dos contadores de fábulas que remontam à antiguidade. Sua obra "Fábulas" não passa de uma compilação em tratamento de reescrita, dado que o autor recolhe e reescreve velhas histórias que circulavam bem antes dele. De acordo com o autor,

As fábulas constituem um alimento espiritual correspondente ao leite da primeira infância. Por meio delas a moral, que não é outra coisa mais que a própria sabedoria da vida acumulada na consciência da humanidade, penetra na alma infante conduzida pela loquacidade inventiva da imaginação. Essa boa fada mobiliza a natureza, dá fala aos animais, às árvores, às águas e tece com esses elementos pequeninas tragédias donde ressurte a "moralidade", isto é, a lição da vida. O maravilhoso é o açúcar que disfarça o medicamento amargo e torna agradável a sua ingestão. $\mathrm{O}$ autor nada mais faz senão dar forma às velhas fábulas que Esopo, La Fontaine e outros criaram. Algumas são tomadas de nosso "folklore" e todas trazem em mira contribuir para a criação da fábula brasileira, pondo nelas a nossa natureza e os nossos animais sempre que isso é possível.

(LAJOLO, 2009, p.103) 
Lobato faz referência às suas bases de pesquisa que levam a Esopo, La Fontaine e ao folclore brasileiro. O autor define a moral como sabedoria, que a seu ver é ahistórica, invariável, imutável, pois acumula-se na consciência da humanidade. Conforme ele argumenta, os valores morais não se alteram nem mesmo com o transcorrer do tempo, permanecendo os mesmos, independentemente do contexto. A ideia defendida por Lobato de certa maneira procede, visto que muitas sabedorias permanecem. As características atribuídas aos animais nas fábulas contemplam até hoje o imaginário criativo: nas antigas fábulas, a raposa sempre foi associada à astúcia, a formiga ao labor e o lobo à ferocidade.

A atração que a criança possui pelo mundo desconhecido, misterioso, porém próximo dos animais, toma múltiplas formas. Dialogar com o animal, falar sua língua, compreendê-lo é uma parte do universo dos contos e fábulas. Conforme Jacqueline Held,

O diálogo com os animais, o diálogo dos animais entre si, revela-se tema particularmente rico, e pode ser interpretado, no plano do desejo, de diversas maneiras que, sem dúvida, não se excluem, mas, pelo contrário, se completam: luta contra a solidão; melhor conhecimento do "outro"; também descoberta, e talvez anexação, de poderes escondidos que o animal nos comunicaria [...] (HELD, 1980, p.108-109)

O animal em sua perspectiva humanizada possibilita à criança, na maior parte das ocasiões, libertar-se ao encontrar ou projetar seus desejos e temores pessoais frente à sociedade adulta organizada. Exerce também uma função de suporte que permite transpor, simbolicamente, certo número de situações da vida familiar, especialmente a situação de aprendizagem que a fascina.

“O homem deu nome a todos os animais”, composição de Bob Dylan com versão de Zé Ramalho, é destacável na interpretação de Partimpim. O arranjo de abertura da canção faz referência à música da Pantera Cor de Rosa, estabelecendo desde o princípio um diálogo com outra figura que povoou muitos imaginários infantis e adultos. A introdução da música conta com a marcação cheia de swing verde amarelo do baixista Dé Palmeira, e o auxílio da guitarra tocada pela Partimpim. A presença de um coro regido por Mariana de Moraes e de uma série de sonoridades experimentais recriam ludicamente a canção de Bob Dylan, sem, no entanto, ferir seu caráter harmônico. A artista transfigurada em Partimpim imprime humor ao registro, principalmente na versão em DVD, em que se 
apresenta com um chapéu de Cowboy, fazendo uma releitura muito própria do gênero country. A guitarra entoada por ela remete à influência americana, ao mesmo tempo em que a cadência rítmica traz o ritmo de feição nacionalizada, bem brasileiro.

No que se refere a comportamentos infantis, é muito comum verificar que as crianças costumam atribuir atitudes humanas a objetos, plantas e animais. Em seu mundo mágico e infinito, não há fronteiras que separem seres animados de inanimados; todos compõem um único universo vasto e inclassificável. Todos os objetos, aos olhos da criança, são interpretados sob a perspectiva do modelo de atividade humana. Sem empecilhos a criança se comunica com o sol, a lua, as estrelas, a caneca de plástico e o cachorro de estimação.

Outra música que tematiza o universo dos bichos com alto senso de humor é "Criança crionça", um poema de Augusto de Campos musicado por Cid Campos. A inventividade com a linguagem se faz presente nos versos do poeta:

\author{
A onça era sonsa \\ Sonsa de nascença \\ Chegava de manso \\ Para encher a pança \\ Sem pedir licença \\ Jabuti teiú \\ Tucano tatu \\ Macaco saguí \\ Preguiça preá \\ Cutia quati \\ Não tinham descanso \\ Mas uma criança \\ Chamou a responsa \\ Criou uma dança \\ A dança da onça \\ Criança crionça \\ Crionça criança \\ Dançando essa dança \\ A onça desonça \\ Despança \\ Dispensa \\ Sua comilança \\ E hoje só pensa \\ Em dançar a dança \\ Criança crionça \\ Crionça criança \\ Dançando essa dança \\ A onça desonça \\ Despança \\ Dispensa \\ Sua comilança
}


E hoje só pensa

Em dançar a dança

Criança crionça

Crionça criança (In: CALCANHOTTO, 2012)

Esta canção, presente no cd Partimpim3, evidencia a inventividade com a linguagem através da evocação do mundo dos bichos. Os versos de Augusto de Campos, acrescidos pela música de Cid Campos, colocam em evidência o caráter lúdico da canção. Há um brincar com os ritmos e com os jogos de palavras, as sonoridades intencionalmente se confundem, fazendo com que ocorra uma "desmistificação" da figura da onça em sua dimensão acústica e consequentemente semântica. A onça, um dos animais mais ferozes e temidos, perde sua força imbatível por meio da brincadeira sonora, tal qual faz Chico Buarque em seu livro dedicado às crianças, “O chapeuzinho amarelo”(1997). Esta nova versão consiste numa releitura do clássico conto "O chapeuzinho vermelho", dos irmãos Grimm. O compositor inverte a história original e desafia a imaginação do leitor, ao subverter o poder do lobo mau através de um rico jogo de palavras, em que a repetição da palavra "lobo” várias vezes a transforma em bolo: bolobolobolobolobolo. O medo reverte-se em desejo de comer o saboroso bolo. Sendo assim a linguagem em sua faceta lúdica é capaz de atrair fortemente a atenção das crianças. Como afirma Jacqueline Held

O jogo com as palavras - todas as formas de jogo: com os sons e ritmos, com os sentidos, com a colocação da palavra - era, inicialmente, natural à criança, simplesmente porque o jogo está no centro de sua vida. Germe, virtualidade que em si mesma nada tem de genial: não se trata de afirmar aqui que a criança poderia, sozinha, extrair tudo de si mesma, nem que é criador formado e acabado. Germe, virtualidade que, se devem ser alimentados e cultivados, abrem já todos os possíveis, e tanto é verdade que o jogo de palavras está no centro da poesia, na raíz do fantástico (HELD, 1980, p.203).

No transcorrer de seu desenvolvimento, a criança vai sendo socializada pelos "utilizadores adultos da linguagem cotidiana", como afirma Held. Em contato com o falar dos adultos, ela vai domesticando sua fala com "precisão" e consequentemente se desviando da liberdade anárquica dos primeiros tempos. A criação artística exerce assim um papel de resgate desses olhos, bocas e membros “livres” da criança.

A poiesis, como afirma Johan Huizinga (1980), é uma função lúdica. Ela se exerce no interior da região lúdica do espírito, num mundo próprio para ela 
criado pelo espírito, um espaço em que as coisas possuem uma fisionomia inteiramente diferente da que apresentam na "vida comum", onde estão unidas por relações diferentes das da lógica e da causalidade. Em sua função original de fator das culturas primitivas, a poesia nasceu durante o jogo e, enquanto jogo, expandiu os limites da extravagância, da alegria e do divertimento.

Se a seriedade só pudesse ser concebida nos termos da vida real, a poesia jamais poderia elevar-se ao nível da seriedade. Ela está para além da seriedade, naquele plano mais primitivo e originário a que pertencem a criança, o animal, o selvagem e o visionário, na região do sonho, do encantamento, do êxtase, do riso. Para compreender a poesia precisamos ser capazes de envergar a alma da criança como se fosse uma capa mágica, e admitir a superioridade infantil sobre a do adulto. (HUIZINGA,1980, p.132)

Como define Huizinga, a criança, por não estar ainda inteiramente contaminada pelo universo de "seriedades" e compromissos do adulto, e por não corresponder devidamente as prerrogativas do "mundo da ordem", que gerencia a vida adulta, está mais próxima da liberdade do indomado, do selvagem, do visionário. Ela, em sua natural "inadequação" às solicitações da vida prática, possui abertos seus canais de comunicação com vias mais transcendentes, que nesta perspectiva a unem à arte.

"Criança crionça” chama a criançada para fazer parte da "dança da onça”, que traz em sua opulência rítmica um swing que contagia o público infantil e adulto. A música apresenta várias inserções sonoras: até o som típico produzido pela onça é reproduzido na abertura da canção. Entretanto, a exaltação festiva não contempla todas as músicas de Partimpim voltadas para o mundo dos bichos; eles são cantados por ela não exclusivamente de uma forma humorada, como explicita “Criança crionça”. Sobressai também o substrato poético em algumas de suas interpretações mais sóbrias de canções que tematizam os animais, como "Passaredo", "As borboletas" e "Por que os peixes falam francês”. Estas dão destaque à palavra enquanto instância portadora de uma substância poética. “As borboletas”, poema de Vinícius de Moraes musicado por Cid Campos, deixa entrever a magnitude lírica dos versos em forma musical. A artista revela a precisão e afinação no canto que pretende destacar cada nuance da canção.

Os versos do poeta constroem uma aquarela multicromática que exalta cada borboleta em sua singularidade. O registro da gravação em cd traz uma força mais concentrada no canto de Partimpim e na concepção harmônica evidenciada 
no arranjo, enquanto a imagem em DVD permite-nos uma percepção menos minuciosa dos detalhes de sua interpretação vocal. O espetáculo visual objetiva mais o resultado do efeito performático, explicitado no desempenho da artista em cena com o figurino exótico composto por um arco na cabeça repleto de borboletas, que se transforma num capacete mágico.

“Passaredo”, de Francis Hime e Chico Buarque é uma música que ganha um arranjo e interpretação peculiares no cd "Partimpim3”. A profusão de pássaros descritos na letra do compositor é cantada pela Partimpim nesta versão que elimina seu caráter mais sinfônico, explicitado na gravação de Chico Buarque no álbum "Meus caros amigos”. "Passaredo", sob a leitura de Partimpim, ganha um ar mais lúdico, que faz parecer que foi de fato criada objetivando a recepção do público infantil. A levada mostra a sutileza de pequenas intervenções sonoras que remetem aos sons da floresta.

"Por que os peixes falam francês", música de Alberto Continentino e Domenico Lancellotti, também evidencia o destaque concebido ao substrato poético. A canção é uma reverência delicada e singela aos peixes, que são agraciados musicalmente numa entoação que os coloca numa perspectiva humanizada.

Por que os peixes falam francês?

Não alemão

Quem precisar fazer mergulho, natação

Quem precisa fazer discurso no dorso do mar

Vai se matricular num curso de nadar

Deve falar em francês para poder conversar

Todos os peixes do mar falam por bolhas de ar (In: CALCANHOTTO, 2012)

A canção traz a suavidade interpretativa como lema, quase uma música de ninar que embala o sono das crianças. $\mathrm{O}$ universo do mar tão entoado em alguns trabalhos de Calcanhotto, como "Maritmo" e "Maré”, é novamente vivenciado através de um olhar que se dirige para a singularidade dos peixes. A voz da cantora se sobressai sobre uma base que impõe a ênfase na guitarra tocada por Berna Ceppas, acrescida pelo som de sintetizadores e samplers.

O mundo composto por uma diversidade de pequenos seres e objetos é enaltecido pela Partimpim. Em sua exibição de uma variedade de minúcias, notase o sofisticado jogo que a artista elabora brincando com as dimensões. A alternância de perspectivas dimensionais é trabalhada por ela ao longo de seus 
espetáculos. Os versos das canções que dão vida aos pequenos animais como passarinhos, borboletas, sapos, lagartas, formigas e peixes são reelaborados visualmente nos cenários e figurinos. Na inversão da perspectiva das grandezas residem valores sentimentais profundos, sendo assim Partimpim adentra na densidade construtiva do imaginário infantil por meio de jogos que relativizam as dimensões. Bachelard (2006) afirma que "só habita com intensidade aquele que sabe se encolher”, e o poder de trazer o mundo e condensá-lo em formas lúdicas, amplia o olhar da criança em relação ao mundo. A ação poética de condensar o vivido em uma superfície miniaturizada, representada por exemplo por meio de um desenho elaborado por uma criança, exige o esforço de trazer o macro para o micro. Conforme Bachelard,

[...] é pela redução do mundo que alcançamos uma das funções mais regulares da imaginação, pois é na miniatura que os valores se condensam e se enriquecem, precipitando imagens, levando-nos para longe, fazendo-nos pequenos para habitálas e vivê-las: encolher-se pertence à fenomenologia do verbo habitar. Só habita com intensidade aquele que soube se encolher. (apud RICHTER, 2005, p.196)

$\mathrm{O}$ ato de miniaturizar o mundo amplifica a experiência vivida, pois, ao mesmo tempo que a criança traz a imensidão do mundo, ela o condensa para vivenciar em sua experiência sensível. Para Bachelard, só podemos ver se sonhamos o que vemos! É pela ação de miniaturizar as coisas, de tocar o intangível através da construção de pequenos desenhos, ou a metaforização de grandes idéias através do uso de pedrinhas ou palitinhos, que a criança habita o mundo e o torna seu.

As pequenas dimensões se alternam com as grandes nos shows de Partimpim. Pequenos objetos e brinquedos são executados pelos músicos ou compõem o cenário pleno de minuciosos detalhes, enquanto figuram também criações de dimensões maiores, a exemplo da saia da bailarina-Partimpim elaborada com um guarda chuva preto revestido de palavras escritas em cores por sua extremidade. “Ciranda da bailarina”, canção de Edu Lobo e Chico Buarque que originalmente fez parte do repertório criado pelos compositores para o Balé Teatro Guaíra, é recriada pela Partimpim numa performance que dá ênfase ao caráter mágico representado pela figura da bailarina. A bailarina descrita na letra de "Ciranda da bailarina” habita um universo mágico, isenta de todas as sensações que acometem os seres humanos. Ela é uma criação etérea, que transcende as 
limitações humanas, não sente dor e não padece de nenhuma doença. Perfeita, inquebrável e intocável, acima do bem e do mal. A cantora declara que a gravou também como uma homenagem à mãe, que exercia o ballet como ofício :

A coisa principal é que ela é dedicada à minha mãe, bailarina. Enquanto bailarina, não como mãe, ela era aquele ser inatingível de que fala a canção. A canção trata do humano da forma que as crianças gostam [no disco original, de 1983, era cantada mesmo por um coro infantil]: escatológica, engraçada, é quase um complemento da forma como o Arnaldo Antunes, lá no ciber (ciber-littera, um site brasileiro destinado a publicar e debater literatura) está falando do humano, do ponto de vista infantil [...] Eu não cheguei a ver a minha mãe atuar, na verdade ela já só coreografava, mas vi muitas fotos dela. Talvez isso me desse uma imagem dela que eu podia apenas projetar, uma imagem sempre glamorosíssima, no palco iluminado, em pontas[...] (www.adrianacalcanhotto.com.br)

Esta consiste numa excelente música para se trabalhar com as delimitações dos planos real e imaginário, que circundam as mentes dos pequenos em formação. A bailarina, em sua concepção etérea, é continuamente contraposta aos atos da vida, como revela a letra da canção. O verso "Só a bailarina que não tem” pontua toda a música elaborando construções antitéticas. A realidade da existência com suas intempéries e necessidades é contrastada com a assepsia da bailarina.

\author{
Procurando bem \\ Todo mundo tem pereba \\ Marca de bexiga ou vacina \\ E tem piriri \\ Tem lombriga, tem ameba \\ Só a bailarina que não tem \\ E não tem coceira \\ Verruga nem frieira \\ Nem falta de maneira ela não tem \\ Futucando bem \\ Todo mundo tem piolho \\ Ou tem cheiro de creolina \\ Todo mundo tem \\ Um irmão meio zarolho \\ Só a bailarina que não tem \\ Nem unha encardida \\ Nem dente com comida \\ Nem casca de ferida ela não tem (In:CALCANHOTTO, 2010)
}

Partimpim, transfigurada por instantes em bailarina, no palco, reproduz alguns movimentos típicos do ballet, dando graciosidade a sua interpretação. O desempenho corporal da artista apresenta muitas variações de acordo com a música a ser interpretada. Como se trata de um espetáculo direcionado basicamente para o público infantil, há uma ênfase considerável na questão da 
performance e do figurino, visto que é acima de tudo por meio da força causada pelo impacto visual que a criança fixa sua atenção no que lhe é mostrado.

No DVD “Partimpim2”, nota-se que a artista utiliza ainda mais a força das cores e as impressões causadas pelos figurinos. Inteiramente fantasiada de robô, ela entra no palco brincando com o jogo de identidades. A princípio não é Calcanhotto e nem Partimpim, mas um estranho robô que vai decompondo seu disfarce em sintonia com o ritmo da música. A artista fala sobre o conceito impresso em Partimpim2:

Eu estou comprando objetos, instrumentos, brinquedos, coisas, desde que terminou a outra temporada. Somaram-se coisas da outra, objetos da outra temporada a esses novos, trabalhei de novo com o Helio Eichbawer. Mas esse show é todo diferente de conceito, musicalmente, espacialmente, com o cenário, são outras idéias, é outra banda. E era isso uma coisa que eu achava importante, já que a minha idéia é fazer uma discografia, uma sequência Partimpim, é que ela não se repita, não fique fazendo o que já foi feito. Isso é importante para me manter motivada e fazer com que o Partimpim seja sempre para mim um desafio (http://www.youtube.com/watch?v=safM5pNYoDQ).

A artista, através desse depoimento, deixa claro o quanto objetiva fazer de seu trabalho uma constante renovação, não reduzindo Partimpim a uma fórmula pronta e tecnicamente programada. A experimentação e a inventividade consistem em seus princípios básicos de criação. Partimpim 2 dá continuidade à existência do heterônimo criado por Calcanhotto, mas com novas experiências criativas. O fato de a cantora optar por novos músicos, já indica um desejo de transitar por diferentes modos de execução, dado que cada músico possui sua maneira própria de conceber e imprimir qualquer sonoridade. Sua releitura de "Bim Bom”, uma dentre as mais conhecidas composições de João Gilberto, traz sua marca rasurante. A cantora uniu a bossa do cantor, violonista e compositor com a batida de samba- reggae do Olodum. No texto de apresentação do livro "Bim Bom- a contradição sem conflitos de João Gilberto”(1999), de Walter Garcia, Caetano Veloso diz que, comparada às canções de Tom Jobim, "Bim Bom” parece uma brincadeira de criança. Em contrapartida, trata-se de uma composição de João Gilberto que, em sua extrema singeleza, apresenta-se como pretexto para ele exercitar as mais delicadas sutilezas de sua invenção, confirma Caetano. Com apenas um minuto e doze segundos na gravação original, "Bim Bom”, ao lado de “Chega de saudade”, faz parte da consolidação da estética da Bossa Nova, que contribuiu para a mudança de rumos da música popular brasileira. 
Bim bom bim bim bom bom

Bim bom bim bim bom bim bom

Bim bom bim bim bom bom

Bim bom bim bim bom bim bim

É só isso o meu baião

E não tem mais nada não

O meu coração pediu assim, só

Bim bom bim bim bom bom

Bim bom bim bim bom bom

Bim bom bim bim bom bom

É só isso o meu baião

E não tem mais nada não (In: CALCANHOTTO, 2010)

Partimpim recria este clássico de João Gilberto, ao mesmo tempo que lhe rende homenagem. Com uma imensa peruca acobreada na cabeça, no estilo Black Power, ela canta "Bim Bom" cheia de swing. A letra da música apresenta o predomínio de negativas, com a exceção da frase "é só isso o meu baião”. "Baião" e "coração”, dois signos de concretude inseridos na canção, indicam o processo de mimetização sonora buscado pelo músico. O compositor Ronaldo Bôscoli disse, e o pesquisador musical Ruy Castro registrou em sua obra "Chega de saudade”, que João Gilberto procurou reproduzir sonoramente, em "Bim Bom”, o balanço sonoro das lavadeiras com bacias de roupa na cabeça. Partimpim faz uma sutil menção a esse fato no show, ao pegar uma bacia de prata e colocá-la na cabeça acompanhando o movimento rítmico da música com o gingado de seu corpo. Vêse que a artista, neste caso, mergulha na tradição e cria sua própria performance, elaborando uma interpretação que simultaneamente resgata o ideário da canção, mas de maneira diferenciada. Esse diálogo tradição/modernidade evidenciado ao longo do percurso criativo de Calcanhotto, pode ser verificado também em Partimpim. A cantora recria, com seu formato lúdico, composições pertencentes ao acervo do cancioneiro nacional e internacional, transitando entre gêneros como a Bossa Nova, marchinha de carnaval, rock e balada.

“Acalanto”, de Dorival Caymmi, é recriada por Partimpim, que traz em sua interpretação toda a singeleza sugerida pela canção de ninar. A voz suave e o timbre mais para o agudo da cantora, concebem o clima ideal para a interpretação. O criador das canções praieiras, que traz em suas composições o primado de uma construção melódica e versificada minimalista, pode ser compreendido como um dos mais importantes legados na formação da artista. A busca pelo essencialismo, que pontua o projeto musical de Calcanhotto, fundamenta também a edificação da 
obra de Dorival Caymmi. Ao reler estas canções, ela coloca em evidência os princípios que norteiam sua incessante procura pela forma concisa, enxuta, reduzida em sua essência.

De acordo com Francisco Bosco, há no projeto construtivo das composições de Caymmi uma espécie de "ética da criação', ou seja, o tempo da criação para Caymmi “é imponderável, e não se recomenda forçá-lo; acatando-o, só se cria o indispensável” (BOSCO:2006, p.18). Subsiste neste criador uma delicada ética da criação, situada entre a atenção e a dádiva, entre o dispor-se e o deixar vir que culminam na ideia do absoluto pleno e espontâneo:

É essa ética da necessidade o critério primeiro que garante a qualidade das canções. A ela se combina o imperativo de uma simplicidade exigente, que requer muita elaboração precisamente para que se atinja uma simplicidade que não seja redundante, porém surpreendente. Tal como dizia Cacaso, também a obra de Caymmi “ só para ficar nua precisa de sete costureiros”. A simplicidade como resultado, a elaboração como método. Elaborar, nesse caso, pode significar apenas esperar, deixar que o tempo trabalhe a canção: é por isso que Caymmi às vezes demora anos para dar por concluída uma música - não se trata de preguiça, e sim de rigor e sabedoria. Necessidade, simplicidade e elaboração: eis aí os princípios composicionais norteadores da obra Caymmiana. (BOSCO, 2006, p.18,19)

Esse princípio “redutor” presente no projeto elaborativo de Caymmi, ressaltado por Bosco, se intersecciona com o projeto construtivo de Calcanhotto. Mesmo sob a égide de sua persona Partimpim em “Acalanto”, prevalece uma interpretação é guiada pelo princípio da economia Caymmiana. O arranjo é elaborado sem o uso de ousadias experimentais, respeitando a intensidade concentrada em sua forma compactada. Caymmi é um compositor que jamais se excede em manifestações passionais, mesmo quando tematiza seus estados interiores não se dilacera nas tensões da carência. Trata o sentimento com delicadeza, como se assim preservasse a integração de seu ser com a natureza, conforme elucida Luiz Tatit (2002). As emoções culturalmente marcadas, como ciúme, frustração, vingança e desprezo, não fazem parte de sua dicção. Ele busca a emoção humana essencial; sendo assim, em algumas canções anula-se como compositor, pois suas músicas parecem sempre ter existido, a exemplo de “Acalanto”. Não possuindo nenhuma formação musical, Caymmi criou batidas e toques de violão específicos para sua dicção. Todos os elementos de suas composições são elaborados juntos, ritmo, harmonia, texto e melodia, em pequenas partes, sem pressa de conclusão. 
Um dado a ser destacado nas criações de Caymmi é sua propensão à periodicidade por tematização, ou seja, seu texto quase sempre decantatório solicita melodias reiterativas. Por meio dessa reiteração, ele tematiza sua terra, sua gente, seus amores e o mar. Conforme analisa Tatit, o compositor dá um tratamento personalista ao violão, propondo batidas rítmicas inusitadas no domínio da canção. Caymmi traz em suas criações um pouco do folclore, da canção de roda, do samba, sempre deixando em evidência sua predileção pela simplicidade e despojamento.

Percebe-se, então, que, em sua versão de “Acalanto”, Partimpim preserva toda a essência Caymmiana, numa interpretação que dá destaque à suavidade e delicadeza. A guitarra barítono, tocada por Alberto Continentino, e as demais guitarras conduzidas por Davi Moraes e Pedro Sá, em segundo algum ferem a essência minimalista da música. A voz da cantora se projeta muito suavemente, sem nenhum excesso ou vibrato, apenas trazendo a beleza quase crua dos versos de Caymmi.

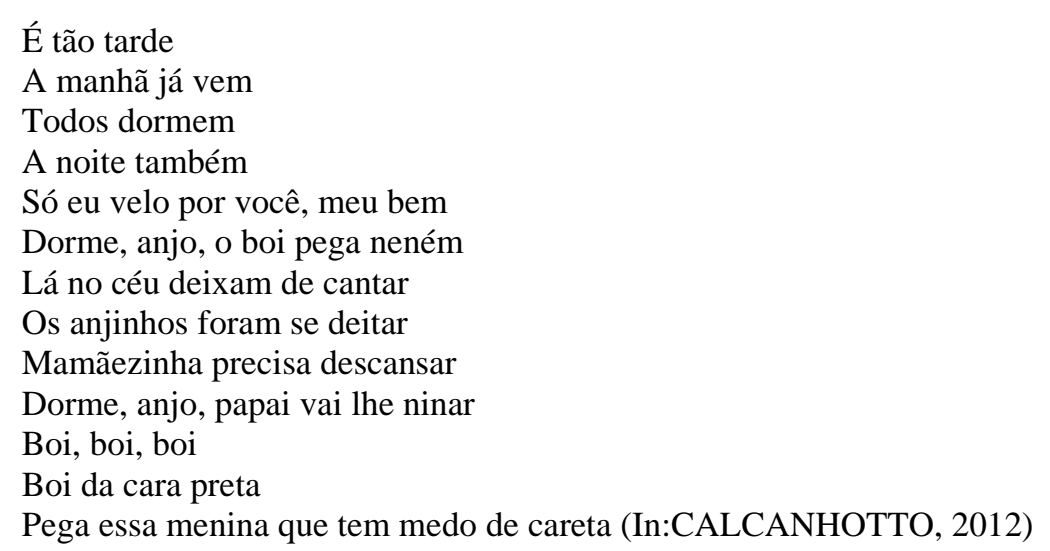

Por meio desse canto em reverência a Caymmi, constata-se novamente o quanto a proposta musical da artista expressa em Partimpim transcende um enquadramento limitado a uma diç̧ão estritamente infantil. A interpretação de “Acalanto” pode figurar em qualquer repertório, não exclusivamente circunscrito ao mundo das crianças. Partimpim mostra em sua interpretação a força atemporal da música de Caymmi, que ultrapassa gêneros e gerações, possibilitando novas e surpreendentes releituras.

A vertente mais lírica das interpretações de Partimpim deixa subjacente em algumas interpretações o tratamento dado pela artista ao caráter inquiridor 
inerente às crianças. "Saiba”, de Arnaldo Antunes, é uma canção elaborada em forma de frases afirmativas, em que o compositor aborda o assunto da existência a partir da passagem por ícones que marcaram o mundo. De Einstein, passando por Freud, Platão, Simone de Beauvoir, Buda, Galileu, Nietzsche, Fernandinho BeiraMar e outras personalidades, o músico retira a aura desses indivíduos que se transformam em seres comuns, mortais:

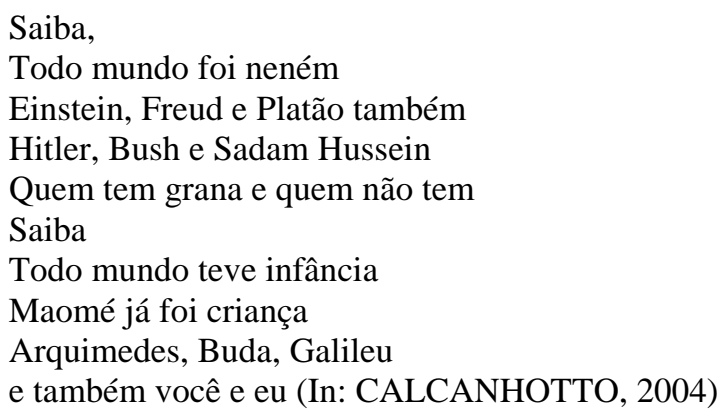

A música, conduzida numa levada suave, quase se aproxima de uma canção de ninar. Os ícones que marcaram a história do mundo, com sua imensidão de luzes e trevas, são retomados nos versos numa dimensão que os iguala sob uma perspectiva anti glamourizante. A interpretação de Partimpim e a de Arnaldo Antunes se assemelham em suas propostas: ambos dão ênfase ao minimalismo na projeção de suas vozes, que se sobrepõem sobre bases que exploram uma sequência reduzida de notas. Há um processo de desconstrução da força que incide sobre o imaginário coletivo construído ao redor das entidades de feição "mítica” postas na música. Figuras totemizadas, como Freud, Buda e Maomé adquirem uma feição mais humana, terra a terra. Partimpim, ao interpretar "Saiba", traz para o universo infantil sutis frases-respostas que vão ao encontro das espontâneas indagações das crianças. A vida e a morte são temas que se revelam por meio de uma canção que traz a aparência de leveza e descompromisso.

A multiplicidade de indagações que circundam o universo infantil é explicitada com pujança em "Oito anos”, composição de Paula Toller inspirada em sua vivência com o filho. Partimpim interpreta esta música, que expõe uma diversidade de perguntas feitas pelas crianças, numa fase da vida marcada pela intensa curiosidade a respeito de tudo: 
Por que os dedos murcham

Quando estou no banho

Por que as ruas enchem

Quando está chovendo

Quanto é mil trilhões

Vezes infinito

Quem é Jesus Cristo

Onde estão meus primos

Por que o fogo queima

Por que a lua é branca

Por que a Terra roda

Por que deitar agora

Por que as cobras matam

Por que o vidro embaça

Por que você se pinta

Por que o tempo passa (In: CALCANHOTTO, 2004)

Paula Toller coloca em forma de canção o instinto inquiridor comum às crianças, que costumam crivar os adultos de perguntas, muitas vezes até difíceis de serem respondidas. Inúmeros "porquês" rondam a mente inquieta dos pequenos, que desejam saber a razão da existência de tudo, desde o mais corriqueiro gesto ou objeto, até questões de difícil resolução relacionadas a um universo metafísico: "Por que o tempo passa/Por que que a gente morre”. Ávida por desvendar o mundo em sua vastidão, a criança é um ser inquieto por natureza, insaciável em sua sede de novidades e descobertas. O senso de humor é destacável na interpretação de Partimpim, que interpreta “Oito anos” juntamente com sua banda, dando ênfase a uma levada rítmica cheia de swing. 


\section{Encartes}

Calcanhotto, além de revelar em suas performances um apurado senso estético, explicita nos encartes de seus cds trabalhos que valorizam a qualidade do tratamento visual. Cada encarte traz uma proposta única que dialoga com o conteúdo das músicas. Flertando com a literatura, o cinema e, sobretudo, as artes plásticas, esta artista incorpora, contrapõe e superpõe conceitos. As artes plásticas figuram em destaque nas capas, que fazem inferência a diversos artistas e obras: Helio Oiticica, Andy Warhol, Diego Velasquez, Mondrian, Helio Eichbauer, entre outros, despontam como referências dialógicas.

“Enguiço”, o primeiro cd de Calcanhotto, lançado em 1990, mostra uma capa colorida que alude às cores da bandeira nacional, a cantora com um buquê de rosas numa das mãos e vestida com peças de cores distintas: calça amarela, cinto preto, blusa lilás, blazer vermelho e sapatos brancos compõe um quadro de feição fauvista. O fauvismo, corrente artística surgida no início do século $\mathrm{XX}$, aliada à pintura, possui como uma de suas fundamentais características a máxima expressão pictórica, cujas cores são utilizadas com intensidade. As cores são trabalhadas em sua forma pura com o objetivo de delimitar planos, fundar perspectiva e modelar volume. O uso da cor pelos pintores transcendia simplesmente a caracterização dos objetos, pois servia também para expressar as emoções. Rostos esverdeados e céus vermelhos apareciam nas telas cujas cores explicitavam pura emoção, associadas a calor, frio, temor, criatividade e alegria. Matisse, um exemplo ímpar do movimento fauvista, elegeu cores puras, presentes no cotidiano.

O enquadramento que compõe o fundo sobre o qual a cantora se posiciona traz sugestões geométricas, vários retângulos em diferentes dimensões dão constituição ao cenário. O plano chapado mimetiza a entrada de uma casa em que a cantora, em pé sobre um degrau no formato de um retângulo verde, olha para o céu mirando o infinito, uma alegoria das inúmeras possibilidades sonoras que iriam advir deste disco de estréia. A menção às cores da bandeira do Brasil se faz numa proposta plástica: destacam-se por exemplo as distinções no uso do 
amarelo, que na bandeira aparece no contorno do retângulo e na capa do CD dividido num pequeno envoltório de um retângulo e na calça de Calcanhotto. O aparecimento das cores da bandeira nacional não insinua uma cantora que inaugura sua carreira com canções de caráter ufanista ou que tragam a questão da brasilidade como linha de frente. Neste primeiro álbum o repertório é meio difuso e parece deixar mais indagações que afirmativas. Como dissemos no capítulo anterior, "Enguiço" evidencia a inadaptação a transposição de uma estética com predominância performática para o disco. O repertório, que inclui composições de Eduardo Dusek, João Donato, Roberto Carlos e da própria artista, deixa em destaque certo ecletismo que não coloca Calcanhotto como uma cantora de um gênero específico, como Bossa Nova ou pop-rock. O álbum "Enguiço” traz como marca destacável o tom irônico, em que a artista ousa em performances que beiram o excessivo e o caricatural. Essa estratégia, que tem no impacto sua maior aposta, manifesta a filiação de Calcanhotto à estética da ruptura, comum nas vanguardas. O encarte de "Enguiço” inaugura uma série de diálogos que a artista irá fazer com as artes plásticas ao longo de sua carreira. Como idealizadora do conceito dos encartes de seus discos ou até mesmo como desenhista, ela expande seu potencial pictórico. Numa entrevista concedida a Ricardo Ivanov, a cantora declara

Tenho meu trabalho de música, mas sou interessada nas questões da arte contemporânea. E essa era uma questão que me dividia: escolher entre a música ou as artes plásticas. Hoje tenho isso mais claro. Não necessariamente pinto ou faço trabalhos. Na verdade vejo isso tudo somado. A arte é um universo que eu adoro, as soluções que esses artistas encontram em suas trajetórias. No caso do Hélio Oiticica, no Brasil, ele é uma pessoa cujo trabalho sempre me prega grandes sustos, impactos. Na verdade eu me interesso pelos grandes artistas, independente de escolas. (www.terra.com.br/musica/adrianacalcanhotto/entrevista.htm)

Como revela Calcanhotto, sua produção musical transcende o universo específico da música; ela é uma artista que demonstra um diálogo permanente com outras modalidades de criação artística, com destaque para as artes plásticas e a literatura. Em sua criação, tudo se relaciona, música, poesia e artes plásticas formam um conjunto com suas singularidades em contínuo intercâmbio.

“Senhas”, segundo disco da cantora, dá destaque ao diálogo com as artes plásticas: o encarte evidencia um diálogo com as obras do pintor Piet Mondrian. Fotos idênticas em preto e branco mostram a artista numa postura que alude à 
famosa obra do escultor Auguste Rodin, intitulada "O Pensador". A foto de Calcanhotto não traduz a expressão inteira de seu corpo, como ilustra a escultura de Rodin. Com o queixo apoiado sobre a palma da mão esquerda e vestida com uma blusa preta, ela mira um ponto à distância, revelando uma postura mais ereta em relação à da obra de Rodin, quando a figura do homem exibe uma pequena inclinação na cabeça. A expressão facial da artista quase nada revela de sua emoção: sem manifestação de felicidade, medo, dor ou espanto Calcanhotto está impassível. Uma fotografia se estrutura na forma de um pequeno quadrado interno emoldurado em azul que leva um pequeno pigmento verde em seu interior. Outro pequeno quadrado é emoldurado em vermelho e insere um pequeno pigmento amarelo na mesma proporção do verde. A composição do encarte alude às obras de Mondrian, que explorou as cores azul, vermelho e amarelo em várias dimensões retangulares. Este artista propunha a destruição dos planos coloridos pelas linhas e um de seus atos destrutivos consistia na oposição figura/fundo, que segundo ele baseava-se na limitação perceptiva básica de nossa visão encarcerada, e de todo o cometimento da pintura. Para Mondrian, a pintura realizava-se como um modelo teórico que provia conceitos e criava condutas relacionadas à realidade: não apenas interpretava o mundo, mas consistia numa manifestação plástica de alguma lógica.

Verifica-se que Calcanhotto produz um encarte com um visual pictórico visando também à coerência com a proposta das músicas: há citações diversas que englobam a pintura e o cinema:

Eu ando pelo mundo prestando atenção

Em cores que eu não sei o nome

Cores de Almodóvar

Cores de Frida Kahlo, cores ( In: CALCANHOTTO, 1992)

O cineasta espanhol Pedro Almodóvar e a pintora mexicana Frida Kahlo consistem em duas referências significativas presentes na música "Esquadros”. Tanto o cineasta quanto a pintora explicitam em suas obras trabalhos impactantes com as cores. Almodóvar desde suas produções iniciais revela uma predileção por cores fortes e uma estética que privilegia certo exotismo. As cores quentes, sobretudo o vermelho, são características inconfundíveis em suas criações e que marcam a sua assinatura. Entretanto os vermelhos jamais aparecem sós, costumam explodir junto com os tons de azul e verde, sendo o contraste entre as cores 
complementares uma marca singular da obra deste cineasta. Há uma evidente extravagância nas roupas e adereços, na maquiagem composta por cores fortíssimas e traços marcantes. Principalmente em sua primeira fase, desponta uma estética do exagero que se sobressai em cada ambiente, figurino e maquiagem. A predominância deste proposital excesso o levou a ser considerado pela crítica como um cineasta que se fundamenta por uma proposta estética kitsch. Este termo, de origem alemã, é utilizado para classificar objetos de valor estético distorcidos ou exagerados e que em geral são considerados inferiores à sua cópia existente. Abraham Moles (1975) diz que o Kitsch é uma atitude, ou seja, uma ação de uma sociedade diante dos seus objetos de consumo. Um estilo marcado pela ausência de estilo. O Kitsch consiste numa mistura lúdica de vários elementos, geralmente com o único propósito de ornamentação. Ele sobrepõe estilos artísticos, materiais, cores e formas de uma maneira harmônica e irreverente; Consequentemente, é uma arte essencialmente sincrética, pois fundamenta-se na junção de vários elementos retirados de distintas escolas e artistas, sem muito critério. Não existem regras numa combinação kitsch. Vale misturar num mesmo ambiente diferentes tendências; por exemplo anjinhos barrocos podem figurar ao lado de cópias de quadros de Matisse, bonequinhos de plástico e latas de refrigerante. Toda essa aparente confusão faz do kitsch uma arte da alegria e da embriaguez dos sentidos.

O Kitsch se enquadra intrinsecamente na vivência de Almodóvar. Ele se faz presente na sociedade espanhola e desponta na criação do cineasta por meio de sua profunda relação com a cor e na influência evidente da Pop Art em seus primeiros filmes. Santos católicos, melodramas, paixões arrebatadoras, além de uma profusão de objetos baratos do consumo popular invadem os cenários almodovarianos revelando o Kitsch como sua marca maior.

Frida Kahlo fez do autoretrato sua mais profunda forma expressiva. Esta artista pintava-se olhando no espelho e reproduzia em cores seu variados reflexos que expressavam uma vida marcada pela dor transfigurada em liberdade criativa. Seu espelho/tela era uma espécie de moldura- recorte de suas percepções, sonhos e devaneios. As cores fortes evidenciadas nas obras desta artista mexicana traduzem a dor e a intensidade de uma arte que está indissociavelmente ligada à vida. 
Desta forma, Calcanhotto não se refere aleatoriamente a Almodóvar e Frida, visto que ambos possuem características semelhantes que se entrecruzam, o choque de cores é o ponto crucial que predomina tanto nos figurinos e telas da pintora quanto nas obras do cineasta.

A compositora constrói seu mundo sonoro-plástico através dos diálogos que estabelece com artistas de segmentos diversos. Frida Kahlo e Almodóvar diluem-se em suas performances musicais juntamente com outros artistas. Os elementos de feição kitsch que surgem vez ou outra nas concepções visuais dos encartes de seus discos põem em evidência questões que envolvem a produção artística contemporânea.

Alguns títulos de canções do álbum "Senhas” também enunciam um jogo cromático como “Tons” e "Negros'. Nas letras destas músicas, a artista traz as cores como motivo de destaque, especialmente “Tons", dedicada ao pintor Iberê Camargo, composta do início ao fim com cores que se intercalam.
Roxos
Todos
Pretos
Partes
Pratas
Andrades
Azuis
Azares
Amarras
Amar
Elos
Amargores
Calipsos
Cortesias
Cortes
Cores e
Rancores
Luzes
Milagres
Lilases
Rosas
Guimarães...
Mulatos
Dourados
Rubores
Castigos
Castanhos
Castores
Havanas
Avanços e
Brancos 
Cobranças
Cinzentos
Cimentos
Crianças
Nas sarjetas
Nojentas
Imagens
Violeta
Magentas
Laranjas
Matizes
Cremes
Crimes
Cobaltos
Assaltos
Turquesas
Pérolas
Aos hipócritas
Ocres
Terras
Telhas
Gelos
Gemas (In: CALCANHOTTO, 1992)

Calcanhotto, ao elaborar a letra de "Tons", vai construindo jogos cromáticos que aludem à obra do pintor, desenhista e gravador Iberê Camargo. Considerado um dos mais importantes pintores brasileiros do século XX, ele inicialmente se revelou voltado para uma estética figurativista, trabalhando a paisagem, a figura humana e a natureza morta, seguindo uma concepção naturalista-expressionista que tinha na cor sua característica principal. Iberê se manteve fiel ao segmento naturalista durante longo tempo, até que foi se despindo dessa maneira de pintar e deu origem aos carretéis e ciclistas que consistem em pontos altos de sua criação. Por meio da invenção de seus "Carretéis", o pintor faz um retorno afetivo à infância, em que sua expressividade pictórica composta por cores fortes, deixando aflorar uma forte carga emotiva. Em "Tons", a compositora superpõe cores-palavras no movimento rítmico da canção, que homenageia a criação de Iberê Camargo.

Em "Negros" Calcanhotto também explicita um jogo cromático que se efetua pela contraposição entre as cores negro e branco, deixando às claras uma intenção crítica. Impressões de ordem sinestésica sobressaem nos versos que criam pequenos quadros, que mesclam o olhar e a sensação expressos pelas cores negro e branco, permeadas de cheiros, sons e sabores. 
O sol desbota as cores

O sol dá cor aos negros

O sol bate nos cheiros

O sol faz se deslocarem as sombras

A chuva cai sobre os telhados

Sobre as telhas

E dá sentido as goteiras

A chuva faz viverem as poças

E os negros recolhem as roupas

A música dos brancos é negra

A pele dos negros é negra

Os dentes dos negros são brancos

Os brancos são só brancos

Os negros são retintos

Os brancos têm culpa e castigo

E os negros têm os santos

Os negros na cozinha

Os brancos na sala

A valsa na camarinha

A salsa na senzala

A música dos brancos é negra

A pele dos negros é negra [...] (In: CALCANHOTTO,1992)

Assim como na canção “Tons” a compositora elabora uma contínua superposição de cores que criam uma ambiência plástica, em "Negros” ela também estrutura uma letra que revela construções cromáticas que explicitam articulações de ideias. Nesta composição a artista transcreve em verso e som sugestões imagéticas e a imagem pode ser compreendida como algo que

embora nem sempre remeta ao visível, toma alguns traços emprestados do visual e, de qualquer modo, depende da produção de um sujeito: imaginária ou concreta, a imagem passa por alguém que a produz ou reconhece. (JOLY, 1996, p.13)

Calcanhotto é uma artista em amplo sentido, visto que, no ofício de cantora, não se dedica exclusivamente ao ato de compor e cantar; ela se envolve inteiramente no processo de feitura de um $\mathrm{CD}$, que engloba outras questões além dos procedimentos relacionados ao som. A cantora participa da formatação do conceito das capas que muito dizem de seu ideal estético. O álbum "Senhas", por exemplo, explicita cores fortes na composição do encarte que se relacionam com o imaginário de artistas citados nas letras, como a pintora Frida Kahlo e o cineasta Pedro Almodóvar. A canção "Senhas”, que abre o CD, é uma espécie de música manifesto em que Calcanhotto, por meio de uma série de antinomias, tenta desconstruir certos paradigmas que desafiam o universo da criação. Experimentar as possibilidades cromáticas, visando um resultado próximo ao kitsh é um dos 
objetivos da artista nos álbuns "Enguiço” e "Senhas”. Há uma sofisticação predominante, mas que, em certos momentos, se embaralha com uma porção over, estratégia intencionalmente criada pela artista para brincar com as linhas de fronteira que separam a criação artística. Fundir Leno e Lilian, Caetano Veloso, Frida Kahlo e Mondrian parece um dos objetivos de Calcanhotto que deseja fugir a qualquer estandardização. Num bate papo conduzido por Júlio Diniz e Paulo da Costa, ela fala sobre a ausência de fronteiras entre a criação artística : "Não gosto de territorializar a canção, eu acho que as minhas letras são muito visuais, imagéticas. Na verdade eu me identifico com os artistas, não com a linguagem” (www . adrianacalcanhotto.com.br).

“A fábrica do poema”, terceiro cd de Calcanhotto, mostra na capa do encarte a artista fotografando-se, de frente, diante de um espelho, metaforicamente refletindo sobre a sua criação, a exemplo do artista espanhol Diego Velásquez no quadro "Las meninas". A imagem da cantora se projeta sobre um fundo oval emoldurado em rosa e dividido entre as cores laranja e amarelo. Todo o restante desta face do encarte é azul, a cor que nos álbuns seguintes irá aparecer em abundância, simbolizando o mar. Na contracapa do encarte tem-se a foto de vários livros empilhados com os títulos das 15 músicas do CD escritos em suas calhas, o que remete a criação musical de Calcanhotto à linguagem da literatura. Literatura e música se entrecruzam constantemente nas criações desta artista. "A fábrica do poema” é um CD inteiramente voltado para a relação literatura /música através do qual ela deseja deixar explicita sua faceta literária. “A fábrica do poema”, composição que abre o cd, consiste num poema de Waly Salomão musicado por Calcanhotto. Este poema dá ênfase à expressão de uma linguagem seca e antimusical em que a reflexão sobre a criação poética permeia os versos:

\author{
Sonho o poema de arquitetura ideal \\ Cuja própria nata de cimento \\ Encaixa palavra por palavra, tornei-me perito em extrair \\ Faíscas das britas e leite das pedras. \\ Acordo. \\ E o poema todo se esfarrapa, fiapo por fiapo. \\ Acordo[...] ( In: CALCANHOTTO, 1994)
}

O interior do encarte também leva um depurado trabalho em que a artista dá continuidade à literatura como conceito primordial. Suas páginas, que abrigam as letras das músicas escritas à máquina, mostram fotos de folhas brancas de papel 
amassadas ao fundo, como se a informalidade desse mais sentido a uma proposta aparentemente biográfica. Simples desenhos feitos à caneta esferográfica ilustram as páginas ao lado de rabiscos, setas e dedicatória. Calcanhotto estabelece com o ouvinte um pacto "narrativo visual” na medida em que forja seu diário musical. A artista expõe no encarte do CD pequenos pedaços de sua vida: fotografias, fragmentos de bilhetes, anotações esparsas.

Essa espécie de pequeno diário que a artista vai construindo e compartilhando nos conduz às reflexões de Philippe Lejeune, um dos nomes mais destacáveis na pesquisa autobiográfica contemporânea. Em “O pacto autobiográfico” (2008), o autor utilizando-se da posição de leitor de gêneros de literatura íntima, coloca em discussão o funcionamento do texto autobiográfico. Conforme o teórico, a "escrita de si” pode ser compreendida como "uma narrativa retrospectiva em prosa que uma pessoa real faz de sua própria existência, quando focaliza sua história individual, em particular a história de sua personalidade” (LEJEUNE, 2008, p.14).

Lejeune não exclui de suas reflexões seções de autorretrato, nem de diário de uma obra, e, quanto à expressão da individualidade de uma narrativa, o autor afirma que aspectos sociais e políticos podem ser incorporados nos textos autobiográficos. Um dos pontos cruciais da obra de Lejeune diz respeito ao pacto de leitura que ele acredita que deve ser firmado entre autor e leitor (LEJEUNE: 2008). Lejeune defende que o leitor deve ler o texto autobiográfico de acordo com a intenção daquele que o produziu; o leitor não pode estar bloqueado em relação à recepção da obra.

Ao tentarmos relacionar as idéias de Lejeune ao formato do encarte do CD “A fábrica do poema”, devemos pensar que a inclusão de fotos e pequenos rascunhos no álbum da artista compõem um caráter narrativo. Armando Silva em “Álbum de família: a imagem de nós mesmos” (2008), ressalta que um dos aspectos que fundamentam o mito do álbum de fotografias é o caráter narrativo desses objetos. O mito do álbum fotográfico elabora-se a partir da idéia de morte e de renascimento. É justamente neste "renascimento" que se encontra uma possibilidade narrativa, com a qual o sujeito tenta, por meio dos registros fotográficos, reconstruir momentos vividos. A ideia de morte percorre todo ato fotográfico, e a consciência de que um acontecimento não mais se repetirá (a morte) é que leva um indivíduo a eternizar um momento através de uma foto. A 
função dos objetos fotográficos não se restringe ao olhar e ao manuseio. Próximos da literatura os álbuns fotográficos também contam histórias de vidas e acontecimentos. Calcanhotto, ao dispor fotografias diversas, elabora o seu álbum, que não é para ser visto linearmente, mas em forma desordenada, com interrupções, entradas e saídas.

"Maritmo” sucede “A fábrica do poema”, trazendo as artes plásticas em destaque. Calcanhotto aparece na capa do encarte vestindo um Parangolé vermelho que remete às criações do artista plástico Hélio Oiticica. Em papel vegetal e com o fundo azul, a concepção visual imprime uma elegância quase glamourizada à obra de Oiticica.

A meu ver o Parangolé é a descoberta do corpo. Parangolé para mim é um programa. Parangolés são as capas que eram feitas para vestir, elas são extensões do corpo, elas mudam, elas estabelecem uma relação do corpo com ele mesmo e da estrutura da capa com o corpo e com ela mesma. Mas Parangolé para mim é um programa [...] a primeira vez que eu escrevi um texto em 1965 sobre Parangolé botei assim: "A descoberta do que chamo de Parangolé marca um ponto crucial e define uma posição específica no desenvolvimento teórico de toda a minha experiência da estrutura cor no espaço”. (FILHO, 2009, p.233)

No verso da capa, dentro de um retângulo amarelo, aparecem escritas as instruções elaboradas por Oiticica para a montagem de um Parangolé, em 1968. Uma versão do projeto é transposta na íntegra para o CD, em que, por meio de cinco tópicos, o artista instrui o aspirante a executor de um Parangolé. Três pequenas fotos complementam a proposta em que Calcanhotto exibe sua montagem do Parangolé que ilustra a capa do disco. A cantora se inspira na proposta de Oiticica para criar a canção "Parangolé Pamplona”:

Made-on-the body cape 1968 (Parangolé Pamplona)

Capa feita no corpo $274 \mathrm{~cm} / 108 \mathrm{~cm}$ no comprimento

1-Cada pedaço de pano deve medir 3 yards no comprimento;

2-Para fazer a capa o pano não pode ser cortado;

3-Alfinetes-de-fralda devem ser usados na construção e depois o pano pode ser costurado para fazer a capa permanente;

4-A estrutura construída no corpo deve ser improvisada pelo próprio participante (se precisar da ajuda de outra pessoa, ok) e feita de forma que possa ser retirada sem cortar;

5-Algumas pessoas podem participar juntas, mas uma só cor, i.e, só um pedaço de pano deve ser usado para cada capa. (In: CALCANHOTTO, 1998) 
Parangolé Pamplona

O Parangolé Pamplona você mesmo faz

O Parangolé Pamplona a gente mesmo faz

Com um retângulo de pano de uma cor só

E é só dançar

E é só deixar a cor tomar conta do ar

Verde

Rosa

Branco no branco no preto nu

Branco no branco no preto nu

O Parangolé Pamplona

Faça você mesmo

E quando o couro come

É só pegar carona

Laranja

Vermelho

Para o espaço estandarte

"para o êxtase asa-delta"

Para o delírio porta aberta

Pleno ar

Puro Hélio

Mas

O Parangolé Pamplona você mesmo faz (In: CALCANHOTTO, 1998)

A compositora reproduz no encarte as instruções concebidas por Helio Oiticica para a execução da capa. A linguagem objetiva de Oiticica compõe uma receita simples e alcançável a qualquer indivíduo que possua um pedaço de pano e alguns alfinetes para moldar o Parangolé ao corpo. Liberdade e inventividade despontam de uma criação que segue em oposição a uma proposta simplesmente contemplativa e não interativa. A visão anárquica de Oiticica jamais cedeu a fórmulas prontas; ele trilhou um caminho de rupturas em que a desmontagem de vários preceitos tidos como rígidos e institucionalizados o levou a exploração de novas possibilidades. Em seu percurso criativo transitou por vias que iam na contramão de conceitos estratificados; seus trabalhos punham em cheque o lugar da arte e do artista, em que o objetivo maior era romper com as estruturas hierarquizadas. Ele trabalhou como um inventor que constrói suas obras a partir de suas experiências na vida diária, frequentou o Morro da Mangueira no Rio de Janeiro e incursionou pelas obras dos grandes mestres como Mondrian, extraindo de múltiplas convivências substrato para suas profundas pesquisas plásticas, sensoriais e culturais. Oiticica propõe a interação obra/espectador com a ruptura da postura passiva e limitadamente contemplativa daquele que frui o objeto de 
arte. Nos Parangolés o indivíduo comum torna-se também um participante da criação. Conforme reflete este artista, a arte deve sair dos guetos circunscritos a elite e abranger todos sem qualquer espécie de restrição.

\begin{abstract}
Algo surpreendente aconteceu: a moda, o mau ou bom gosto, não existem tudo depende da invenção livre, espontânea; chegará o dia em que cada pessoa fará sua roupa segundo sua percepção e vontade, segundo sua aspiração: talvez tenha sido aqui pela primeira vez formulado tal problema. [...] Levaremos as capas Parangolé para que o público faça sua experiência vestindo-as. Às pessoas que lá comparecerem serão solicitadas criações de sua autoria para manifestação seguinte quinze dias depois, e assim sucessivamente. Quero fazer voltar o Parangolé ao gênio anônimo coletivo de onde surgiu, e com isso jogar fora os probleminhas de estética que ainda assolam nossa vanguarda em sua maioria, transformando a pequenez desses problemas em algo maior, que seria a transformação do próprio conceito e da abordagem do que seja arte. (FILHO, 2009, p.54)
\end{abstract}

O espectador-participante envolvido no trabalho de arte proposto por Oiticica adentra num jogo dinâmico de relações sociais e espaciais, em que, por meio da relação corpórea, acontece toda a magia criativa. Conforme argumenta o criador, vestir-se com um Parangolé implica uma "transmutação expressivocorporal”, cuja consciência do corpo torna-se mais aguçada por meio da relação corpo/objeto. A pessoa que se movimenta com o Parangolé cria espontaneamente sua própria performance numa expressão corporal que continuamente se renova. Vestido com um Parangolé o indivíduo toma mais consciência não somente do seu corpo, mas do ambiente que o envolve e que se transforma em cenário, um palco onde toda a ação ganha novo significado.

O corpo é como o BRANCO NO BRANCO uma etapa-estado necessário para a chegada ao NOVO DIA DO INVENTOR. As experiências e a invocação experimental envolvendo o corpo sempre hão de aparecer e reaparecer de novos modos: tantos quantos seriam os indivíduos a experimentá-las. (FILHO, 2009, p.199)

A própria forma do Parangolé favorece a exploração da diversidade expressiva visto que ele não é firme; sua textura permite considerável maleabilidade pois é "tensionada, suspensa nos vãos do espaço intercorporal, cujos mecanismos e dinâmicas ele revela, ainda que fugazmente, como o resvalar suave de uma silhueta que passa na periferia da visão”. (BRAGA, 2008, p.148)

Em 2012, mais de uma década após o lançamento do álbum "Maritmo”, que contém a canção "Parangolé Pamplona”, Calcanhotto faz performances com os Parangolés de Oiticica, no MAM-Rio de Janeiro. Com os cabelos longos e 
escuros na altura dos ombros, que se diferenciam do visual apresentado durante toda a carreira, a artista introduz sua performance com um Parangolé laranja. Fazendo movimentos giratórios favorecidos pela maleabilidade do tecido, ela move braços, cabeça e pernas. Em seguida, o Parangolé laranja é substituído por um rosa em cetim, que aparenta possuir uma dimensão consideravelmente maior, permitindo uma amplitude de movimentos. A câmera que se projeta de cima para baixo na performance de Calcanhotto com o Parangolé rosa, favorece uma visibilidade no plano total da extensão de movimentos criados por ela. Em seguida, a câmera se aproxima em close e revela a cantora com um terceiro Parangolé em duas cores, amarelo e verde, fazendo menção à bandeira nacional. A artista faz outros movimentos giratórios e a câmera mostra, além de seu corpo que veste o Parangolé, fragmentos do cenário ao fundo; a cor cinza do concreto predominante do MAM confere um tom de sobriedade à cena. Novamente, retornam imagens de Calcanhotto movimentando-se com o Parangolé rosa e o de dupla cor, verde e amarelo. A roupa da cantora, composta por um conjunto monocromático de calça e blusa pretas, anula qualquer outra interferência cromática por parte da artista, fazendo prevalecer o enfoque unicamente no Parangolé. O quarto e derradeiro Parangolé é azul e evidencia a amplitude de movimentos realizada pela cantora. Em entrevista à revista "Bliss” ela afirma:

Não é uma roupa, que não é uma capa, não é uma escultura, a cor no ar. E para fazer com que isso aconteça também não é só dançando, é uma coisa que não existe, é meio que uma coisa sem nome, incrível Parangolé. Do Parangolé que ele faz para o Parangolé que a gente pode fazer é um passo. Daí que saem esses versos "branco no branco no preto nu", porque originalmente o Parangolé era para ser usado pelos negões pelados, coisa que eu nunca cheguei a ver, nos vídeos em geral as pessoas estão de roupa. A ideia era essa. ("http://www.youtube.com/watch?v=0Tt-RU4XWZU\&feature=related"

__http://www.youtube.com/watch?v=0Tt-RU4XWZU\&feature=related_)

Calcanhotto pensa a obra de Oiticica musical e corporalmente. Neste vídeo que divulga sua entrevista, ela, além de expressar suas idéias, também faz algumas performances com um Parangolé laranja. Contrastando as cores preto e branco de sua blusa e calça com a capa, a artista experimenta possibilidades expressivas com seu corpo e também adentra em outras partes do universo Oiticicano presentes no Centro de Artes Helio Oiticica, local em que foi realizada a entrevista. O programa mostra Calcanhotto interagindo com obras que convidam o espectador a participar tocando, amassando, enfim, sentindo a textura. 
A criação de Oiticica motiva Calcanhotto a elaborar a música "Parangolé Pamplona”, no entanto não é somente este artista que desponta no encarte de "Maritmo" como influência plástica. Ela escolhe também uma obra de Andy Wahrol para dar continuidade ao diálogo com as artes plásticas. Calcanhotto expõe no encarte uma fotografia da lata de sopa Campbell, uma entre outras várias obras de Wahrol difundida mundialmente.

Andy Wahrol tornou-se internacionalmente conhecido por seus trabalhos de colagem e serigrafia, o que lhe assegurou o título de pai da Pop Art. Seus trabalhos baseavam-se na reprodução de fotos e produtos oriundos dos veículos massificados (televisão, jornais, revistas e panfletos publicitários). Qualquer coisa que estivesse ligada à vinculação com a mídia, o que consequentemente lhe favorecia abundante publicidade, era utilizada nas obras de Wahrol. Na concepção deste artista, a obra de arte, assim como qualquer outra mercadoria, é um bem para ser disponível e negociado no mercado consumidor. A produção em escala, vista em suas obras por meio de contínuas reproduções, tinha como alvo preferencial amplas personalidades expostas pela mídia, principalmente ícones hollywoodianos. Entre os trabalhos de Wahrol mundialmente conhecidos, destacam-se as várias séries dedicadas à atriz Marilyn Monroe, em que ele se utiliza de uma imagem da atriz produzida no auge de sua carreira para exibi-la em várias perspectivas. Não somente a atriz hollywoodiana Marilyn Monroe serviu de inspiração para o artista pop; Elizabeth Taylor, Audrey Hepburn e James Dean passaram pelo olhar mitificador/desmistificador de Wahrol. A produção em larga escala que domina a criação deste artista dá sentido à reflexão sobre a queda da aura do objeto, discutida por Benjamin no clássico "A obra de arte na era de sua reprodutibilidade técnica” (1987). No contexto em que vigoram as obras de Wahrol, a singularidade e ritualização que envolviam a obra de arte perdem o seu sentido, passa a prevalecer um desejo de posse por parte do espectador para com o objeto. Assim sendo, distanciamento contemplativo transforma-se em proximidade e posse. Nas palavras de Benjamin:

Fazer as coisas “ficarem mais próximas” é uma preocupação tão apaixonada das massas modernas como sua tendência a superar o caráter único de todos os fatos através de sua reprodutibilidade. Cada dia fica mais irresistível a necessidade de possuir o objeto, de tão perto quanto possível, na imagem, ou antes, na sua cópia, na sua reprodução. (BENJAMIN, 1987, p.170) 
Além de dialogar com as criações de Helio Oiticica e Andy Wahrol, Calcanhotto, na página ao lado da imagem da lata de sopa Campbell de Wahrol transformada em "Cariocas”, mostra sua invenção plástico-musical denominada “Guitarra favela”. O desenho da Guitarra Favela, feito possivelmente em nanquim ou caneta esferográfica preta, evidencia uma guitarra de feição bem nacional, composta de recursos baratos que podem ser encontrados nos lixões das favelas. Braço de bambu, papelão, pinho de caixote, tela de arame, lata de alumínio, paubrasil e ipê são os materiais necessários para a execução da "Guitarra favela”. Nesta invenção de Calcanhotto ressalta-se a ironia em que ela brinca com o ofício de artista plástica, com a realidade social brasileira e até mesmo com as propostas revolucionárias dos artistas, sobretudo Oiticica. Se Oiticica criou os Parangolés compostos de matéria barata extraída do cotidiano, a cantora brinca de criar seu instrumento musical que pode ser construído e manipulado por qualquer um, sem distinção de classe econômica. Como indica o próprio nome, é principalmente o pobre da favela o beneficiado pela criação musical da artista. Canclini define:

O campo cultural ainda pode ser um laboratório. Lugar onde se joga e se ensaia. Frente à "eficiência" produtivista, reivindica o lúdico; frente à obsessão do lucro, a liberdade de se trabalhar as heranças sem créditos que permanecem na memória, as experiências não capitalizáveis que podem livrar-nos da monotonia e da inércia. Às vezes essa concepção de arte como laboratório é compatível com a eficácia socialmente reconhecida. (CANCLINI,1998, p.113)

Como define Canclini, no universo capitalista em que dominam as relações de lucro, restam pequenas expressões que seguem à deriva, revelando objetivos que transcendem a questão monetária. A concepção de arte como laboratório é uma das novidades apresentadas na atualidade. Sob a denominação de arte sustentável, muitos artistas têm experimentado criar a partir de materiais antes descartados como lixo. A obra projetada por Calcanhotto se enquadra nessa perspectiva sustentável e ao mesmo tempo dialoga com a liberdade criativa reverenciada por Oiticica.

Folheando todo o encarte de "Maritmo", adquire-se a impressão de que o tratamento plástico/visual dá complementariedade ao sentido das canções, formando a unidade do disco. Este álbum abre um jogo performático que engloba a tríade som/palavra/imagem. A força do som e da palavra não suplanta a carga de informações e impressões sugeridas pelas imagens. Elas em alguns contextos exercem um papel de narrativa, contam a história do processo de feitura de uma 
música, como mostra o fragmento de um bilhete de Calcanhotto endereçado ao músico Hermeto Paschoal. A artista convida-o para tocar nesta composição, que traz o experimentalismo como marca. Se Hermeto é um representante da pura criação que se efetua numa profusão de experimentações sonoras com múltiplos instrumentos, ao lado de Calcanhotto ele desenvolve uma performance que opta pela redução, em que o piano reina quase monocórdico.

Ao lado da transcrição da letra, aparece a foto reduzida da partitura elaborada pelo músico. "Canção por acaso" estabelece uma conexão com a “estética do menos”, minimalista. Calcanhotto compõe uma canção que privilegia uma sequência recorrente de acordes e palavras, repetindo exaustivamente a preposição “sem”, que indica falta, privação, exclusão.

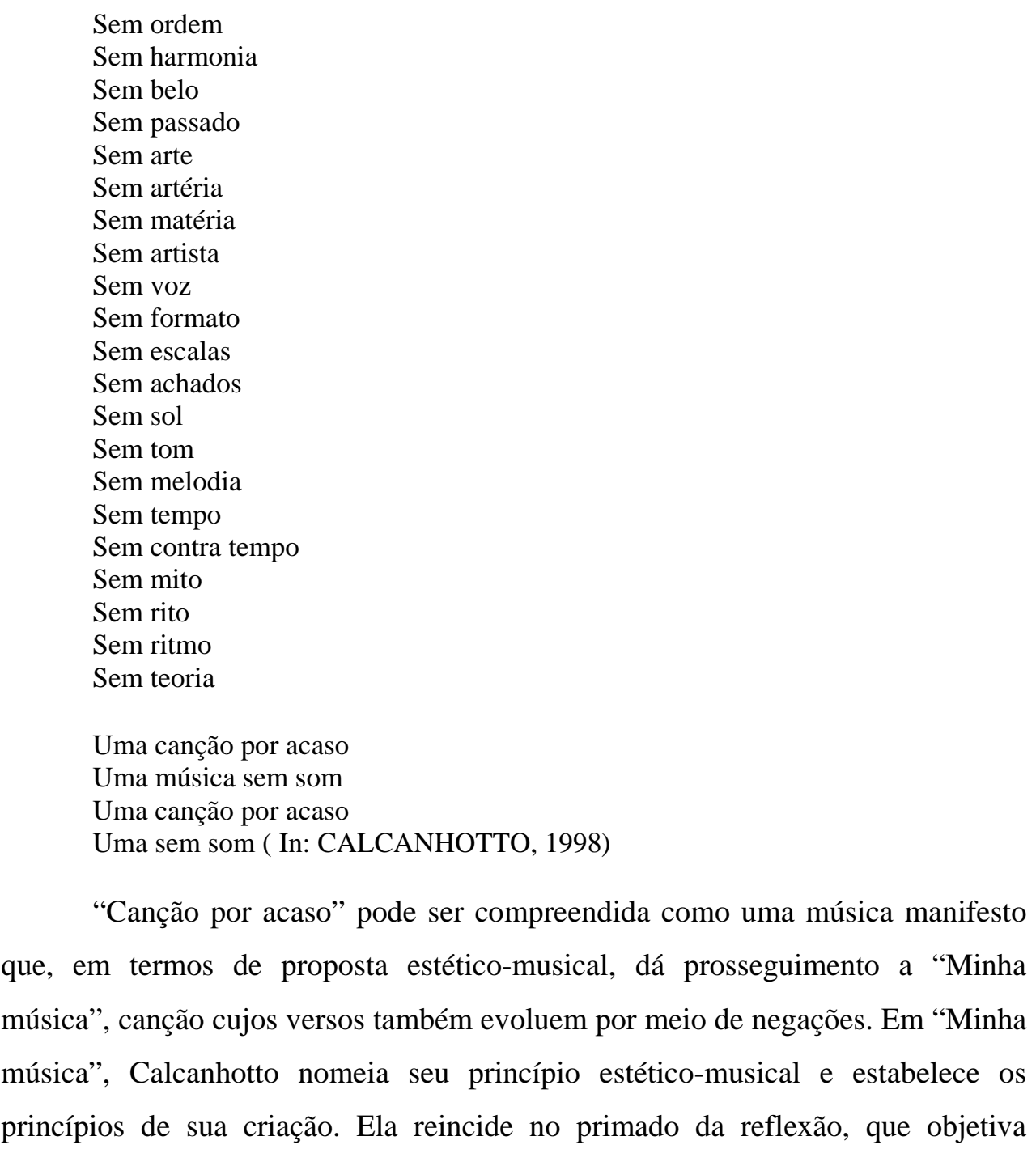


romper com os paradigmas estéticos e ideológicos que cerceiam a invenção musical.

Minha música não quer ser útil

Não quer ser moda

Não quer estar certa

Minha música não quer ser bela

Não quer ser má

Minha música não quer nascer pronta

Minha música não quer redimir mágoas

Nem dividir águas

Não quer traduzir

Não quer protestar

Minha música não quer me pertencer

Não quer ser sucesso

Não quer ser reflexo

Não quer revelar nada

Minha música não quer ser sujeito

Não quer ser história

Não quer ser resposta

Não quer perguntar

Minha música quer estar além do gosto

Não quer ter rosto, não quer ser cultura

Minha música quer ser de categoria nenhuma

Minha música quer só ser música

Minha música não quer pouco ( In: CALCANHOTTO, 1994)

Em "Minha música”, Calcanhotto desenvolve um processo desconstrutivo no desenrolar dos versos. Através de uma sucessão de negações, ela tenta formar seu “ideal de canção”, que almeja estar destituída de uma série de condições impostas por uma perspectiva tradicional. A música a qual a compositora aspira obter se coloca numa condição de "antimúsica”, uma música que chegaria ao seu esvaziamento absoluto.

"Público" sucede o álbum "Maritmo" e traz uma considerável inovação em relação aos anteriores, pois foi inteiramente gravado ao vivo, com exceção apenas de três faixas extras gravadas em estúdio: como "Maresia", "Medo de amar" e “Dona de castelo”, esta canção-tema do filme "Doces poderes”, de Lúcia Murat. O encarte traz uma foto a cores da cantora na capa, sentada num banquinho e acompanhada por seu violão. A cor preta serve de fundo a todas as folhas do 
encarte como se a intenção fosse reproduzir o cenário onde ela realizou sua apresentação. Destaca-se numa das páginas a foto tirada pelo fotógrafo Pedro Moraes, em que a artista toca violão e dirige seu olhar para frente. Mais adiante, outra foto de Calcanhotto tirada à distância mostra o cenário do show em sua composição minimalista: sentada num banquinho e posicionada no meio do palco, ela toca seu violão, cercada por mais dois violões posicionados ao seu redor e um pequeno banco com um som portátil em cima. O móbile vermelho construído por Hélio Eichbauer paira no alto e joga uma nuance de cor. Na folha ao lado destaca-se o poema "Remix século XX", de Waly Salomão, que em sua forma circular labiríntica, convida o leitor a interagir em sua leitura, dado que, em sua forma estática, algumas palavras encontram-se de cabeça para baixo. O leitor, ao girar a folha, lê o poema em movimento. Entre outras fotos, ressaltamos uma a cores em que Calcanhotto ilustra sua proposta performática, ao vestir-se com um terno preto que alude à indumentária utilizada pelo poeta Mário de Sá Carneiro pouco antes de se suicidar.

“Cantada” traz na capa do encarte uma sugestão de sensualidade, evidenciada nos lábios de Calcanhotto, mostrados em close e pintados num tom de vermelho. O contorno da capa toda preta dá ênfase ao retângulo que compõe a moldura dos lábios da cantora, evocando suas múltiplas sugestões. A concepção visual da capa de "Cantada” assemelha-se à imagem criada para o disco "Fatal”, gravado ao vivo pela cantora Gal Gosta, em 1971, trabalho considerado um marco pela crítica da época. Dirigido por Waly Salomão, "Fatal” foi um show que se ergueu na base da tradição que se misturava com certo experimentalismo de vanguarda. O repertório misturava canções do folclore baiano, como "Fruta Gogóia” e "Bota a mão nas cadeiras”, ao legado dos grandes compositores, como Geraldo Pereira e Ismael Silva, revistados numa estética cool. A versão em álbum duplo, com registros ao vivo e praticamente sem cortes e mixagens, procura deixar quase incólume a atmosfera do show. Gal Costa, musa do desbunde em 1971, incitava o público tocando seu violão meio precário, mas plenamente integrado à proposta do espetáculo. A capa de “Fatal” revela também os lábios da cantora em close, porém a imagem se expande um pouco mais e capta parte do queixo, buço e microfone. Os lábios semiabertos e numa tonalidade de vermelho intenso deixam explícita uma intencionalidade erótica. "Cantada” e "Fatal” se 
assemelham em suas apresentações visuais, mas o conteúdo do disco de Calcanhotto não explicita relação dialógica com o álbum de Gal Costa.

Os trabalhos de arte apresentados nas capas dos discos da música popular brasileira seguem uma longa tradição, que teve sua maior expressividade principalmente nas décadas que antecederam o surgimento do CD. Os vinis possibilitavam vasta riqueza criativa, pois eram grandes e muitas vezes até em formato duplo. O Brasil tornou-se fabricante de lps desde 1951, mas nesta época ainda não se tinha formado uma cultura que valorizasse a "capa de disco”. Alguns conceitos básicos eram dominados pelos fabricantes. Assim, por exemplo, num disco de cantor ou cantora, colocava-se em destaque a foto do intérprete; num disco de orquestra, escolhia-se às vezes uma paisagem ou um modelo. Raramente havia uma compatibilidade entre o estilo da capa e o tipo de canção gravada no disco. Nas capas, apareciam desenhos, fotos, textos e vários outros adornos que nada diziam respeito à realidade do repertório. Foi somente com o desenhista e artista gráfico César Villela que ocorreu uma transformação no visual das capas de disco brasileiras. Ele concentrou seu talento na feitura das capas para o pequeno selo Elenco, criado por Aloysio de Oliveira, em 1962. As capas da Elenco eram produzidas em preto e branco, sempre com um pequeno detalhe em vermelho e a foto do artista em alto contraste sobre o fundo branco. A escolha do preto e branco não foi resultante exclusivamente de uma intenção econômica, mas de uma vontade de imprimir simplificação à proposta estética de César Villela. As capas se baseavam numa sofisticação que valorizava uma estética minimalista, a qual entrava em sintonia com a atmosfera bossanovista correspondente ao repertório dos discos. O primeiro disco lançado pela Elenco mostra o poeta e letrista Vinicius de Moraes ao lado da atriz e cantora Odette Lara. O poeta encontra-se sentado num banco com as pernas cruzadas, coluna ereta e cigarro na mão, encarando diretamente o espectador sugerindo uma postura de racionalidade. Odette, em pé, com uma perna flexionada, explicita sensualidade, dando margem à primazia do sentimento. $\mathrm{O}$ design da capa ilustra então a harmonia entre razão e sentimento, trazendo nesta simbiose o grande impacto diferencial em relação aos trabalhos que o antecederam. Outro recurso interessante surgido no selo Elenco, e que ainda hoje vigora nos CDs, é a presença de textos que reproduzem o visual manuscrito. Calcanhotto, em seus CDS, faz uso frequente de formas gráficas que 
se assemelham ao manuscrito, ou até mesmo utiliza alguns manuscritos seus fotografados.

A predominância da cor branca nas capas dos discos da Elenco favorecia seu fácil reconhecimento pelo público ouvinte, que podia identificar à distância o LP pela singularidade do design. Os diferentes estilos, elementos e características utilizados nas capas dos discos exerciam um papel de diferenciação diante do panorama artístico cultural, destacando-se como marca distinta da Bossa Nova e sua modernidade. A revolução estética criada por esta nova proposta do segmento Bossa Nova, a partir dos sinais distintos em seu design, constitui as bases para a fundação de um campo identitário, no complexo campo cultural brasileiro do início dos anos 60.

A intenção inovadora explicitada no novo modelo de design das capas da Elenco revela um diálogo com a modernidade que se refletia na própria sociedade da época. Havia uma tentativa de reconhecimento social das capas da Bossa Nova, como representante legítimo da cultura nacional. Deve-se levar em conta que a sociedade brasileira do período era pressionada pela influência direta da cultura estrangeira, o que nos leva a refletir sobre o papel exercido pelo mercado exterior, mais precisamente as capas de disco da gravadora Blue Note. Villela define seus pressupostos:

Não se pretende que alguém "entenda" uma capa de LP mas sim que se sinta decisivamente atraído por ela. Assim, deve a capa provocar uma reação imediata, um impulso, um apelo. Seu pior fracasso é passar despercebida: ser um envoltório comum, sem força de venda. A capa deve "soar" graficamente, numa mensagem convincente e fácil de ser gravada. Não devemos nos orientar pelo critério beleza: principalmente no nosso caso é por demais relativo. (Já dizia Voltaire: “a beleza para o sapo é a sapa”). Em ótica, no entanto, somos todos iguais. O truque visualpermitido pela razão gráfica - é a forma mais rápida, direta e rentável de comunicação entre a capa e o individuo. Chamo "razão gráfica" a soluçãosimbólica visual de alguma coisa. Além do mais, esse tipo de capa nos permite, justamente por sua simplicidade, disfarçar a deficiência de impressão. Certas companhias primam pela capa confusa, cheia de detalhes, com dizeres ilegíveis e excesso de cores. É um despropósito. Ao contrário, ao decidirmos por uma "simplicidade de bom gosto", estaremos muito mais perto de obter embalagens ideais para os produtos em questão [...] (CARDOSO, 1960, p.333)

Villela, em sua argumentação, defende a primazia de uma linguagem visual marcada pela economia de recursos, que toque o receptor por seu poder de comunicação objetiva. A simplicidade e o refinamento se aliam na proposta estética da Elenco, que trabalha essencialmente com o uso do contraste entre o 
cheio e o vazio, representado pelo fundo branco sobreposto por uma composição de massas pretas que formam os personagens e os outros elementos do disco. O fundo branco serve como suporte para a forma que se destaca em que o objetivo se dirige para o impacto visual.

O uso de elementos específicos, a exemplo das partituras, além das invenções na tipografia, elaboram uma atmosfera particular a cada capa e fazem referência direta ao artista do disco. O LP de Baden Powel mostra a invenção gráfica no título, escrito com uma font script (manuscrito), expressa uma sensação intimista e remete a um comportamento próprio dos bossanovistas, que costumavam escrever em guardanapos nas mesas dos bares.

O trabalho gráfico respectivo ao tratamento das fotos mostra ligações com a Pop Art, e o período que marca a ascensão dos discos da Elenco coincide com a retomada da arte figurativa, em que o alto contraste era uma técnica bastante comum aos artistas do movimento pop, principalmente Andy Warhol. A conexão com a Pop Art não se dá exclusivamente pelo fato de as fotos serem em altocontraste, mas por explicitarem em alto contraste ícones da cultura massificados pela publicidade e pelo consumo. César Villela, por meio de suas criações, ambicionava transformar seu elenco de artistas em mitos da Bossa Nova, através da reprodução massiva e mecânica das capas de disco.

Vale destacar que a evidência de uma linguagem geométrica e visual nas capas da Elenco ia ao encontro dos movimentos de vanguarda, em que a arte transcende sua função de mero objeto. Busca-se a expressividade e a subjetividade de modo sensível, dando vigor à racionalidade e rejeitando o acaso, a abstração aleatória. O objetivo é exterminar a distinção entre forma e conteúdo e instituir uma nova linguagem, em que é permitido brincar com as formas, cores, decomposição e montagem das palavras.

Sendo assim, as capas da Elenco, ao valorizarem uma estética minimalista, não resultavam num design visual vazio, pois carregavam a influência de conteúdos experimentais de vanguarda, articulados com as situações sociais da época e elementos favoráveis sob uma perspectiva comercial.

Além das criações de César Villela para a Elenco, torna-se importante mencionarmos os trabalhos do designer gráfico e ilustrador Elifas Andreato, artista que exerceu um papel respeitável na cultura brasileira a partir dos anos setenta, quando foi responsável pelo projeto gráfico da antológica “Coleção 
Histórica da MPB”, que marcaria época pela Editora Abril. O lps eram vendidos em bancas de jornal e chamavam a atenção dos compradores pelo trabalho de arte expresso nas capas. As criações de Elifas Andreato eram revolucionárias para a época, tanto na concepção das diagramações como no uso das cores. Pela proximidade do contato que estabelecia com cada músico, era capaz de imprimir sempre sua leitura singular e original. Ele dava destaque às marcas expressivas impressas na face de cada artista, não reproduzia apenas a imagem tal qual uma máquina fotográfica, pois ia no cerne da ânima do músico a ser retratado e soltava sua sensibilidade por meio de caricaturas primorosas. Em entrevista, Andreato diz:

De 1967 a 1969, em apenas dois anos, eu saí da condição de estagiário e passei a chefiar a arte de um grupo de fascículos na Abril Cultural. Foi um avanço muito grande para mim. Esse projeto da MPB viria a me abrir todas as portas depois. Isso foi em 1970, eu estava com uma energia enorme para inventar coisas, trabalhar em cima de idéias que soassem revolucionárias e tal. Era o ímpeto da juventude aliado ao fato de que eu estava pela primeira vez trabalhando no que eu realmente gostava. Com a História da MPB eu me projetei fora das fronteiras da Abril e passei a conviver com aqueles artistas todos. Isso porque eu tinha de fazer a pesquisa fonográfica, eu os acompanhava, passava um tempo na casa deles, fiquei amigo de muitos. Eu era muito moço e convivia com o Cartola, Nelson Cavaquinho, Lupicínio Rodrigues, Pixinguinha [...] Era um mundo fascinante que surgia dentro do meu mundo, eu tinha adoração por toda aquela gente e de repente eles estavam me tratando com reverência, abrindo suas casas para mim. E esse sentimento novo influenciaria de maneira definitiva a arte que eu iria desenvolver para a coleção. Do ponto de vista gráfico, era uma coisa muito revolucionária, até hoje é uma diagramação muito moderna, cheia de brancos, eu tinha uma interpretação para cada personalidade e isso me ajudaria a criar as capas de disco, mais tarde. E eu acho que a importância deste trabalho reside justamente no fato de que ele abriu as portas para a criação da capa de disco no Brasil. (http://www.consciencia.net/2003/12/12/elifas.html)

Andreato é responsável pela mudança da capa de disco no Brasil, pois injetou em suas criações a emoção, um elemento anteriormente raro de encontrar, mesmo nas formas acentuadas por César Villela. O ser humano brasileiro é elemento de destaque em suas capas, que, sob sua inspiração, deixaram de servir simplesmente como elemento de embalagem, de feição exclusivamente industrial, para se transformarem em objetos artísticos que compõem um todo juntamente com a arte do compositor. Numa estratégia visual metalinguística, ele utiliza a capa como mais um componente artístico que se complementa e se comenta. As criações de Andreato estabelecem sempre uma espécie de continuum da proposta 
sonora do músico, resultando num jogo simbiótico sonoro-plástico sempre original.

Por meio de seus desenhos, Andreato percorre a história dos grandes compositores e intérpretes da música popular brasileira, Clementina de Jesus, Paulinho da Viola, Elis Regina, Caetano Veloso, Clara Nunes, Noel Rosa, Pixinguinha, Chico Buarque, Gal Costa, Adoniram Barbosa, Cartola, Vinícius de Moraes, Martinho da Vila entre tantos outros, foram retratados pelo olhar sensível deste artista que incorporou a emoção aos sons, cores e formas.

Tive a grande felicidade de conhecer e conviver com Cartola, com Nelson Cavaquinho, Nelson Sargento, Guilherme de Brito, eu sou um privilegiado, não só convivi como desenhei para eles e humildemente, imagine alguém desenhando com admiração, com profunda admiração. Eu fiz o meu trabalho para a música carioca com isso. Refletindo um pouco hoje sobre essa trajetória ligada a música carioca, tem um começo e sem ele eu talvez não fizesse a obra que fiz. Isso começou de fato com uma capa para um disco do Paulinho da Viola chamado Nervos de aço. (http://www.youtube.com/watch?v=bFNnv5zCM4s)

Os trabalhos gráficos elaborados para os encartes dos CDS de Calcanhotto devem muito de sua qualidade ao legado deixado pelos dois artistas exponenciais, César Villela e Elifas Andreato. As elaborações visuais tendencialmente minimalistas da artista se afinam com a perspectiva sofisticada e clean das capas da Elenco. Tanto César Villela quanto Elifas Andreato possuem uma marca única, que os fazem inigualáveis, originais e não aprisionados a um tempo; são artistas de ontem e de hoje. Por meio deles o trabalho elaborado para as capas de disco ganhou uma dimensão verdadeiramente artística.

No verso da primeira folha do encarte de "Cantada", Calcanhotto incursiona novamente pelo universo criativo de Mondrian, como fez no CD “Senhas”. Uma sobreposição de figuras amarelas em duas intensidades de tom compõe o quadro que faz menção às obras do pintor. Um amarelo fosco contorna um pequeno quadrado amarelo luminoso onde a artista se posiciona mostrando apenas uma parte da face. A participação de Calcanhotto neste quadro por ela inventado se faz em caráter crítico, visto que subjetivamente ela retoma a idéia da arte participativa, defendida por Hélio Oiticica e Lygia Clark. Estes artistas manifestaram um engajamento radical em suas vidas e viveram um processo de contínua atualização através da autoconstrução, desconstrução e experimentação. O suporte do trabalho de ambos foi o corpo, mas não o próprio corpo e sim corpos 
de outros. Oiticica e Clark propunham a interação entre público e obra por meio de criações que só tomavam seu sentido pleno com a participação ativa do espectador. Uma obra de arte, aos olhos desses artistas, não servia simplesmente para ser contemplada à distância, mas tocada, cheirada, sentida, vestida. Oiticica em entrevista a revista Artes explicita sua reflexão sobre arte que vai de encontro a uma proposta participativa.

\begin{abstract}
A arte muda sim, mas faço questão de frisar que não concebo uma nova estética, mas justamente o contrário: elaborar, definir o que conceituo como antiarte. Para mim os conceitos de arte como uma atitude fixa, contemplativa, acabaram - não podemos mais conceber "estéticas", mas sim um modus vivendi do qual se ergueram novos valores ainda nebulosos. O precário, o ato, o "fazer-se", tomam sentido como valores a considerar: mas o principal é a não formulação de "leis" para a arte ou algo assim. A época do racionalismo dominante chega a seu término: daqui por diante o intelecto aparece como parte de uma concepção de uma totalidade da vida e do mundo, na qual aparece a arte como impulso criador latente da vida. Não se trata pois da "arte" como objeto supremo, intocável, mas de uma criação para a vida que seria como que uma volta ao mito, que passa aqui a ocupar um lugar proeminente nessa totalidade. Esse mito seria regido por "estados criativos” em sucessão no indivíduo e na coletividade - não se quer o "objeto arte”, mas um "estado", uma predisposição às vivências criativas; um incentivo à vida. (FILHO, 2009, p.37)
\end{abstract}

As palavras de Oiticica destacam a questão da quebra do revestimento aurático que circunda o objeto de arte. Sob sua concepção, a arte não é para ser assimilada enquanto algo sublime, distante e intocável. A arte deve ser compreendida como criação indissociável da vida, sendo assim uma extensão dos sentimentos, anseios e vivências dos indivíduos. Sua ideia compactua com o ideário preconizado pelos poetas marginais que floresceram na década de setenta, como Cacaso, Chico Alvim e Chacal. Para eles, a poesia não deveria ser uma criação hermética e presa numa torre de marfim, circunscrita apenas a uma ínfima parcela de entendedores, mas feita para ser acessível a todos, vivida e compartilhada intensamente no cotidiano: "Poesia eu não te escrevo/eu te vivo/ e viva nós” (BRITO, 2002, p.55).Assim como Oiticica questionava o papel da arte, dos artistas e dos críticos, havia, por parte dos poetas marginais, uma crítica aguçada ao universo acadêmico, ao papel do intelectual e à cultura bacharelesca. Sob o impulso de antagonismo cultural, a poesia marginal ressuscita o espírito antiburguês, libertando-se dos valores morais e das repressões, trazendo criações em que o lirismo se mistura com certa dose de ironia. Heloísa Buarque esclarece a proposta poética marginal: 
Nos textos, uma linguagem que traz a marca da experiência imediata de vida dos poetas, em registros às vezes ambíguos e irônicos e revelando quase sempre um sentido crítico independente de comprometimentos programáticos. O registro do cotidiano quase em estado bruto informa os poemas e, mais que um procedimento literário inovador, revela os traços de um novo tipo de relação com a literatura, agora quase confundida com a vida. São os já famosos "poemas marginais". (HOLLANDA, 1981, p.98).

Mais adiante, no meio do encarte, aparecem quatro fotos de obras de Hélio Oiticica distribuídas em duas folhas, uma ao lado da outra. O material fotografado faz parte da instalação permanente do artista situada no Museu do Açude, Rio de Janeiro. Desta vez Calcanhotto retoma o universo de Oiticica, mas evidenciando outras criações do artista que se distinguem do Parangolé, que lhe inspirou o CD "Marítmo". Expostas numa área verde, as formas geométricas em grandes dimensões e em cores diversas convidam o espectador a fazer parte deste cenário, interagindo com seu corpo entre os espaços que separam uma obra da outra. Grandes figuras em vermelho, branco, pink e azul produzem um belo efeito contrastante sem tirar a singularidade de cada objeto. A proposição arquitetônica deste artista fundamenta-se no reposicionamento de três aspectos fundamentais: espaço, tempo e a relação obra-espectador. A arquitetura não se limita à sua materialidade ou constituição física, pois

O espaço arquitetural é um campo do qual propositor, objeto e público participam, do objeto material para o processo vivencial. A arquitetura como representação, depositária de significados (pretérito) socioculturais, econômicos e tecnológicos passa a ser facilitadora de significações (presente), veículo para a experiência do corpo. (BRAGA, 2008, p. 134)

A última foto do encarte de "Cantada" traz um close da cantora: entre as obras de Oiticica, ela se posiciona no meio de duas formas triangulares em posição vertical. A plasticidade se compõe na interação entre Calcanhotto e as obras, a cor das alças da camiseta da artista, verde limão, efetua uma harmonia cromática que resulta num quadro ao lado dos triângulos amarelo e rosa. A proposta da interatividade entre obra e espectador cuja análise nos detivemos com mais apuro na "arquitetura” de Oiticica, apresenta sua conclusão imagética nesta foto que encerra o encarte.

José Ramos Tinhorão, em "Música popular- um tema em debate”(1997), argumenta ironicamente sobre a proliferação de pseudônimos na música popular brasileira no período do surgimento da Bossa Nova. Segundo o pesquisador, os 
músicos brasileiros se encontravam demasiadamente influenciados pelos norteamericanos e criavam falsos nomes para ocultar certo complexo de inferioridade. O pianista Johnny Alf tinha como nome de batismo João Alfredo e o cantor Dick Farney chamava-se Farnésio Dutra. O olhar irascível de Tinhorão não perdoou principalmente um dos mais importantes músicos brasileiros:

No caso especial de Tom Jobim, o que se apressou em esclarecer foi que esse apelido se originou do fato de uma sua irmã só chamá-lo, quando criança, TonTon. Ora, numa época em que Farnésio Dutra estava exatamente se transformando em Dick Farney, em que Hilda Soares da Silva se transformava em Leny Eversong, e em que Manuel Xisto virava Fred Williams, e o pernambucano Elpídio Sales Pessoa, nascido em Pau d'Alho, passava a assinar-se Fat's Elpídio, como é que se poderia esperar que Antônio Carlos Jobim não aproveitasse o Ton-Ton para virar Tom, embora Tony fosse o mais correto em inglês? (TINHORÃO, 1996, p.31)

Não foi somente a influência da cultura norte-americana que estimulou a criação de certos pseudônimos, como os criticados por Tinhorão. O período em que a ditadura militar vigorava no Brasil, impondo forte censura, principalmente à criação artística, foi propício para que alguns compositores criassem pseudônimos como única alternativa para difundirem seus trabalhos. "De olho na fresta”, como reflete o sociólogo Gilberto Vasconcellos, artistas e intelectuais tentavam inserirse no universo político-artístico, penetrando justamente nos pequenos recônditos próximos aos órgãos de repressão. Chico Buarque, nos anos 70, criou o pseudônimo Julinho de Adelaide com o objetivo de burlar a censura. Por meio da invenção deste "falso compositor", conseguiu que algumas de suas músicas atravessassem a barreira da censura . Em entrevista concedida a Mário Prata, o "pseudo compositor" solta o verbo, dando suas opiniões sobre música e artistas em geral:

Embora eu não seja cantor, um dia eu pretendo gravar um disco. Você vê, gente que não canta bem como o Chico Buarque, o Vinícius de Moraes, o Antonio Carlos Jobim, estão cantando. Quer dizer,a minha voz não é muito boa mas outro dia eu ouvi o disco do Nelson Cavaquinho e ele é mais rouco do que eu e gravou um disco. Eu posso ter que gravar um dia, entende? Aí a minha foto vai atrapalhar a vendagem do disco, não é? É claro que eu não vou pôr na capa a minha foto. Assim, uma destas menininhas bonitas da Rua Augusta pode comprar pensando que é um sujeito bonito e vende mais o disco, não é? Com a minha cara eu acho que vai vender menos. Então, é melhor não ter a cara do que ter a cara que eu tenho. (ttp://www.chicobuarque.com.br/texto/mestre) 
Partimpim consiste num heterônimo que faz da brincadeira e descontração o seu lema. Com Julinho de Adelaide, Chico Buarque aproveitava o ensejo para expressar nas entrelinhas sua ironia, numa tentativa até de distender momentaneamente o clima opressivo reinante. O compositor criou para Julinho de Adelaide uma identidade própria: o falso compositor era oriundo de família humilde, mas, por ironia do destino possuía um conhecimento musical destacável.

O heterônimo Partimpim surge com propostas que se diferenciam significativamente do que Calcanhotto vinha desenvolvendo. Toda a concepção construtiva da personagem, que envolve figurino, repertório e performance, revela um estilo singular que não se assemelha nem à Calcanhotto dos discos anteriores e nem aos trabalhos desenvolvidos por artistas que se dedicam ao público infantil. Partimpim é uma construção atípica em relação aos modelos massificados de artistas direcionados ao universo infantil, pois lida com a predominância de uma atmosfera lúdica, mas que não infantiliza ou erotiza precocemente as criança. Partimpim proclama a fruição existencial através de um comportamento que traz a descontração como linha de frente, porém jamais dispensa sua consciência crítica que subjaz aos versos que ora contam histórias como "Alexandre”, ora pensam sem maiores abstrações a própria vida, como "Saiba”. Em entrevista Calcanhotto fala sobre a proposta lúdica que define a arte de Partimpim:

Sabe-se pouco dela, mas o pouco que se sabe é muito interessante. Ela só faz o que quer, quando quer e a experiência foi muito interessante. A adesão das pessoas para um projeto como esse onde todo mundo só faz o que quer e quando quer, algum imput que eu quero das pessoas é só de fazer por desejo, por vontade, por interesse de fazer um trabalho. Não é para vir aqui trabalhar, é pra brincar. O show Partimpim tem um espectro muito mais amplo, de criança com gente velhinha, tem adolescente, adulto, tem gente sem criança que é uma coisa que eu não esperava nunca. (www.adrianacalcanhotto.com.br)

Partimpim é aquela que não deixou a curiosidade e o vigor irem embora. Encantada pela natureza, cores, brinquedos, bichos, máscaras e invenções ela canta e diverte as crianças e os adultos em espetáculos que unem música, poesia e visualidade. O encarte de "Partimpim” exibe o caráter lúdico do disco: a cantora brinca com sua imagem que se modifica pelo uso de máscaras diversas. Ela transforma-se em chinês, caveira, gladiador e menina sapeca, explicitando a riqueza de possibilidades que invade o universo infantil. Esta concepção visual alude à arte pop, movimento artístico que se desenvolveu na Inglaterra, em 1950, 
e que surgiu como um repúdio às feições convencionais da arte, opondo-se ao individualismo romântico, ao expressionismo abstrato e à pintura modernista que vigoravam no cenário artístico. Os artistas elaboraram uma espécie de crítica à cultura de massa e buscaram inspiração justamente nas massas para criarem suas obras, aproximando da vida cotidiana e ironizando sua essência materialista e consumista. Embalagens de alimentos, latas de refrigerantes, histórias em quadrinhos, bandeiras e outros objetos serviram de base para a criação dos artistas naquele momento. Eles utilizavam recursos estéticos da publicidade e do consumo como temas e chegavam a transformar em obra de arte o que não passava de simples objeto descartável e consumível, a exemplo das latas Campbell reformuladas por Andy Wahrol.

Os materiais usados pelos criadores da Pop Art derivavam das novas tecnologias que surgiam em meados do século XX como Gomaespuma, poliéster e acrílico. Andy Wahrol, um dos mais célebres artistas pop, fez por meio de suas criações uma crítica intensa à sociedade de consumo e à carência de valores substanciais. Através de uma atitude irônica, brincava com a glamourização e a simultânea falta de densidade da sociedade norte americana:

O que há de bom neste país é que os Estados Unidos criaram a tradição em que os consumidores mais ricos compram essencialmente as mesmas coisas que os mais pobres. Você pode estar assistindo à TV e vê uma Coca-Cola, e você sabe que o presidente toma Coca-Cola, Liz Taylor toma Coca-Cola e logo pensa que você também pode tomar Coca-Cola. Uma Coca-Cola é uma Coca- Cola e nenhuma quantia de dinheiro pode lhe arranjar uma Coca-Cola melhor do que aquela que o vagabundo da esquina está tomando. (SYLVESTER, 2006, p. 346)

Se o primeiro álbum "Partimpim” traz referências explicitas à arte pop, o segundo mostra a Partimpim também na capa, mas com um trabalho de arte um pouco diferenciado em relação ao anterior. Ela desta vez aparece com o rosto em close e vestindo a mesma máscara da capa anterior; verde e rosa compõem a cor do cenário em que a artista com uma luva pink de plástico, faz um sinal com os dedos indicando que este é o segundo álbum da safra. A ludicidade ganha mais espaço no verso da capa em que o projeto gráfico de Luiz Henrique Sá proporciona uma intensidade visual às elaborações, "rabiscos" de Partimpim. Sobre um fundo rosa que reproduz um colorido feito com lápis de cera, material muito usado pelas crianças, principalmente em fase pré escolar, florescem alguns balões em alguns tons de azul. A palavra dois, escrita em letra de forma, utiliza os 
balões azuis para formar a letra "o”, gerando um resultado que dá ênfase ao lúdico.

O interior do encarte é produzido em papel reciclado, com uma sobriedade proposital que permite a visualização das letras grafadas em azul marinho. Partimpim, de certa maneira, retoma a ideia da fruição livre do cotidiano através da espontaneidade de suas criações, que procuram valorizar a brincadeira e a descontração. O lirismo permeia as composições de autoria da Partimpim e suas gravações de músicas de Caetano Veloso, Roberto Carlos, João Gilberto, entre outros. A ludicidade multicolorida não transparece neste caso somente em alguns aspectos que configuram a formatação gráfica do encarte; a escolha do repertório revela a eleição por um poema de Vinicius de Moraes musicado por Cid Campos que é puro lirismo multicolor:

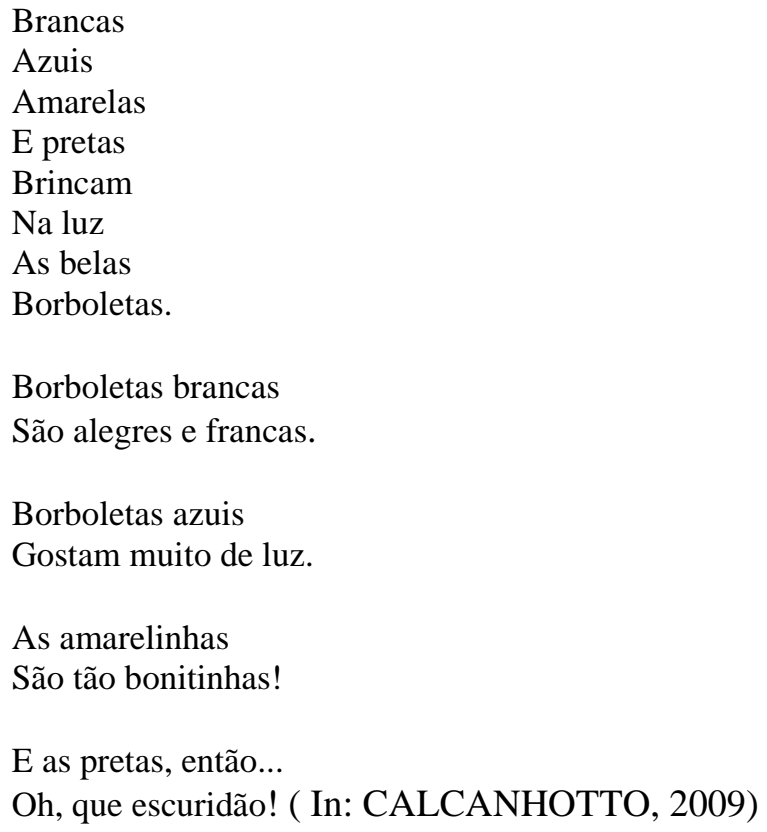

Constata-se, então, que, em "Partimpim I" e "Partimpim II," a proposta fundamental do trabalho visual é ressaltar a plasticidade por meio da valorização de uma pesquisa estética que abrange sobretudo a arte contemporânea, o que se dá através de jogos de cores, desenhos e inserções de imagens que implicam uma entrada lúdica no universo infantil.

Assim como faz Calcanhotto em seus discos, Partimpim também dialoga com um amplo acervo pictórico e sonoro que ultrapassa delimitações nacionais. A arte pop de Andy Wahrol é referência para a elaboração de máscaras, em que 
Partimpim brinca com suas identidades mostrando a ausência de fronteiras entre arte feita para crianças e arte feita para adultos. Em seu mundo composto por uma profusão de misturas Partimpim incorpora tendências distintas que a transformam numa figura rica em suas nuances. Menina, jovem, sem idade, o heterônimo de Calcanhotto celebra acima de tudo a alegria e convida todos para sua festa sem fim, seu eterno carnaval

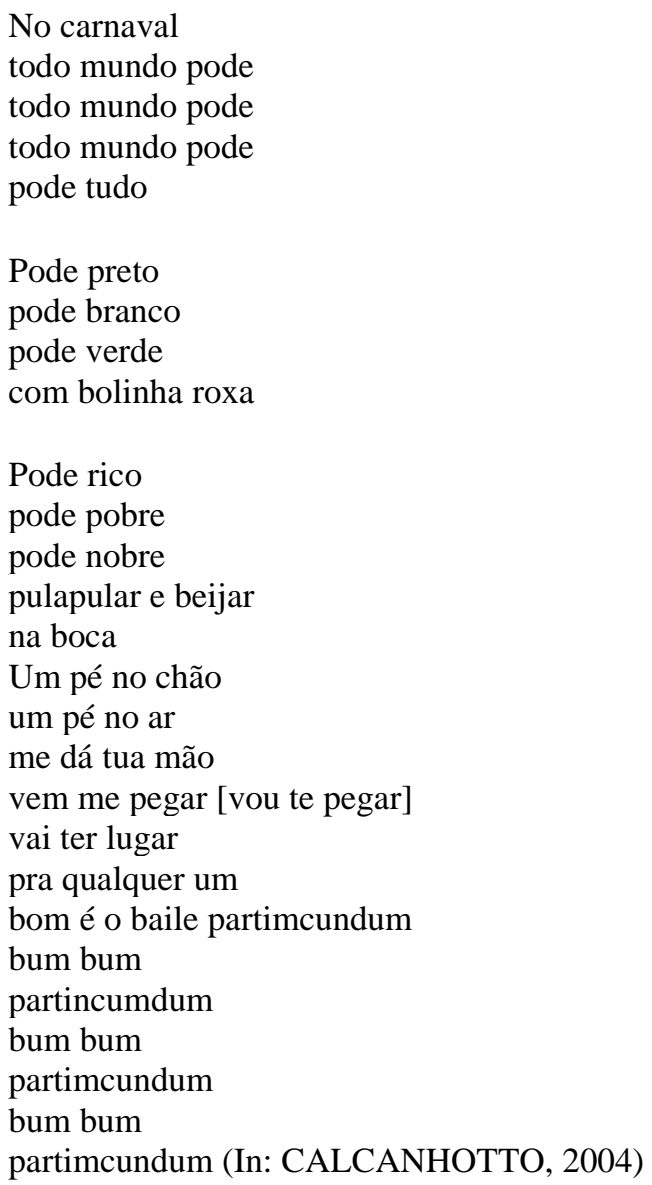

Calcanhotto, além de marcar sua inserção no universo das artes visuais através de sua efetiva participação na elaboração dos projetos dos encartes, abre espaço também para um diálogo plástico com a literatura. A artista toma como desafio o projeto de ilustrar o poema “O poeta aprendiz”, de Vinícius de Moraes, que retorna às editoras numa versão direcionada ao público infantil. "O poeta aprendiz” foi escrito por Vinícius em 1958 e incluído em seu livro "Para viver um grande amor” (1962). Anos depois, o poema transformou-se em canção através da parceria com Toquinho. Ilustrar o poema transformado em canção não é resultado 
de um contato súbito da artista com a obra do poeta. A afinidade já vinha se delineando no percurso musical de Calcanhotto, que já havia gravado algumas músicas de Vinícius em parceria com Francis Hime (Saudade de amar) e Tom Jobim (Ela é carioca, Eu sei que vou te amar). A afinidade da artista com a obra do poeta se dá também pelo fato de Vinícius ter sido um poeta atípico em relação a seus contemporâneos, como Drummond e Cabral. Ele foi um criador que não se restringiu a uma vida burocrática, mas que se inseriu em outros segmentos, como o cinema e a música:

Tudo em Vinícius de Moraes extravasa poesia. A vida, a atitude, a recusa em se levar a sério, o humor, o amor pelas mulheres, a generosidade, a sofisticação, o devastador poder de sedução, o desprendimento, a popularidade, a alma negra, a intimidade com os mitos, o gosto pelo prazer, o espírito vagabundo. E também a prosa, os poemas para crianças. Me perdoem os chatos e suas questões sobre altos e baixos. Vinícius é fundamental. (www.adrianacalcanhotto.com.br)

No livro infantil “O poeta aprendiz”, Calcanhotto interpreta a música e cria as ilustrações para o poema que conta a história de um menino que sonha em ser poeta. Para a criação visual do menino, a artista toma por base o conteúdo fornecido pelos versos acrescido de seu próprio olhar contemporaneizado.

Ele era um menino

Valente e caprino

Um pequeno infante

Sadio e grimpante.

Anos tinha dez

E asinhas nos pés

Com chumbo e bodoque

Era plic e ploc.

$\mathrm{O}$ olhar verde-gaio

Parecia um raio

Para tangerina

Pião ou menina.

Seu corpo moreno

Vivia correndo

Pulava no escuro

Não importa que muro

E caía exato

Como cai um gato.

No diabolô

Que bom jogador

Bilboquê então

Era plim e plão.

Saltava de anjo

Melhor que marmanjo

E dava o mergulho

Sem fazer barulho. 
No fundo do mar

Sabia encontrar

Estrelas, ouriços

$E$ até deixa-dissos.

Às vezes nadava

Um mundo de água

E não era menino

Por nada mofino

Sendo que uma vez

Embolou com três.

Sua coleção

De achados do chão

Abundava em conchas

Botões, coisas tronchas

Seixos, caramujos

Marulhantes, cujos

Colocava ao ouvido

Com ar entendido

Rolhas, espoletas

E malacachetas

Cacos coloridos

E bolas de vidro

E dez pelo menos

Camisas-de-vênus.

Em gude de bilha

Era maravilha

E em bola de meia

Jogando de meia -

Direita ou de ponta

Passava da conta

De tanto driblar.

Amava era amar.

Amava sua ama

Nos jogos de cama

Amava as criadas

Varrendo as escadas

Amava as gurias

Da rua, vadias

Amava suas primas

Levadas e opimas

Amava suas tias

De peles macias

Amava as artistas

Das cine-revistas

Amava a mulher

A mais não poder.

Por isso fazia

Seu grão de poesia

E achava bonita

A palavra escrita.

Por isso sofria.

Da melancolia

De sonhar o poeta

Que quem sabe um dia

Poderia ser. (MORAES, 2003, p.48) 
Este poema de Vinícius de Moraes musicado por Calcanhotto é uma espécie de auto retrato do poeta em que, através da criação do "menino aprendiz”, ele tenta resgatar uma infância que ficou nos recônditos de sua memória. Essa retomada da infância, elaborada numa linguagem repleta de lirismo, sinaliza um fato recorrente na produção dos artistas de várias vertentes, seja do universo pictórico tal qual Picasso e Miró ou seja do mundo literário, como comprova o também poeta Manoel de Barros. No prólogo de sua obra "Memórias inventadas" (2008), Manoel de Barros explicita a questão da tentativa que faz de reconstruir em linguagem poética a memória de seus desejos, devaneios e travessuras. A poesia é território livre para seu lirismo se expandir sem freios, cem que esforço de resgate das primeiras e singulares sensações resulta num rico e maduro exercício de retomada da pureza infantil. Vinícius de Moraes, por meio da invenção do poeta aprendiz, aspira reviver, através da poesia, a magia da infância, um tempo de delicadezas em que era possível estabelecer uma comunhão com as coisas. O mesmo se dá com Manoel de Barros:

\begin{abstract}
Cresci brincando no chão, entre formigas. De uma infância livre e sem comparamentos. Eu tinha mais comunhão com as coisas do que comparação. Porque se a gente fala a partir de ser criança, a gente faz comunhão: de um orvalho e sua aranha, de uma tarde e suas garças, de um pássaro e sua árvore. Então eu trago das minhas raízes crianceiras a visão contingente e oblíqua das coisas. Eu sei dizer sem pudor que o escuro me ilumina. É um paradoxo que ajuda a poesia e que eu falo sem pudor. Eu tenho essa visão oblíqua de eu ter sido criança em algum lugar perdido onde havia transfusão da natureza e comunhão com ela. Era o menino e os bichinhos. Era o menino e o sol. O menino e o rio. Era o menino e as árvores. (BARROS, 2008, p.11)
\end{abstract}

A capa de "O menino aprendiz”, em azul marinho, mostra o desenho de um menino magro com os braços esticados, como se estivesse se preparando para um mergulho na água reproduzida no papel pela cor azul claro. As informações da capa apresentam Calcanhotto como cantora e ilustradora, o que ratifica que a artista assume o novo ofício. Ela cria uma vida lúdica e colorida para os versos de Vinícius, ao elaborar, em forma de desenho, a história conduzida pelo poema. A primeira aparição do menino no interior do livro mostra-o com uma capa vermelha, tal qual um super-herói. No decorrer de algumas páginas, sua imagem é mostrada sobre figuras geométricas coloridas. No momento do jogo de futebol ele se posiciona na lateral de um trapézio verde; quando se relaciona com uma de suas primas um retângulo rosa compõe o fundo. Nota-se que seu modo de 
composição revela uma estética minimalista, assim como se evidencia em sua proposta musical. Os desenhos não mostram excessos de cores revelando um nível de plasticidade que se exercita pela influência de um design clean em sintonia com o ideário estético da artista.

"Melchior, o mais melhor" é mais outro trabalho visual em que a artista trabalha em parceria com o artista plástico Vik Muniz. O universo infantil novamente toma conta da criatividade de Calcanhotto. Ela elabora todas as ilustrações do livro, que conta a história de um menino que sonhava em ser o "mais melhor" em tudo o que fizesse na vida. Melchior desejava ser o "mais melhor" aluno da escola, o "mais melhor" jogador de ping pong, o " mais melhor" dançarino, enfim, o melhor dos melhores. A maior ousadia deste livro consiste na inversão de papéis, a cantora e compositora, que já traz uma longa bagagem de trabalho com a palavra cantada e escrita, dá vazão ao desenvolvimento de uma atividade plástica, enquanto o artista plástico Vik Muniz adentra na criação literária. Essa inversão explícita na obra torna ainda mais evidente o percurso multifacetado e permeado por intencionais provocações que Calcanhotto percorre. Cantora, compositora, instrumentista, performer, desenhista, escritora, todas essas facetas juntas ou momentaneamente separadas dão sentido à identidade sempre questionável e inquietante da artista. Vejamos a maneira como o livro infantil "Melchior, o mais melhor" a define:

A ilustradora

Adriana Calcanhotto é compositora e cantora. Nasceu em Porto Alegre, mora no Rio de Janeiro, mas viaja o tempo todo para fazer shows. Quando canta para crianças, ela é Partimpim. Adriana gosta de brinquedos que tocam música e de instrumentos que fazem barulho, e adora desenhar e fazer colagens. (MUNIZ, 2001, p.61)

Vik Muniz é fotógrafo, desenhista e pintor, conhecido internacionalmente por sua série de trabalhos que investigam sobretudo temas relativos à memória, à percepção e a representação de imagens no mundo das artes e dos meios de comunicação. Suas obras explicitam o uso de diversas técnicas, usualmente extraídas de materiais inusitados como açúcar, doce de leite, gel para cabelo, chocolate líquido e lixo. A ousadia e a originalidade marcam suas produções, como mostra uma réplica da Mona Lisa, de Leonardo da Vinci, realizada com a utilização de manteiga de amendoim e geleia como matéria-prima. Vik explora a 
ambiguidade e hibridez das imagens e este procedimento faz com que suas obras adquiram um caráter sedutor. Este artista se destaca também pela reflexão teórica que desenvolve a respeito da fotografia como meio e suporte de seus trabalhos. Suas imagens construídas com materiais “pobres” e aparentemente insignificantes, como poeira e sucata, promovem uma revisão permanente da História da Arte do clássico ao contemporâneo. Seu trabalho desenvolvido com os catadores de lixo do Aterro Sanitário do Jardim Gramacho, no Rio de Janeiro, dirige o foco de ação-transformação para uma vasta camada de gente absolutamente descartada do universo de apreensão-recepção da obra de arte, que, ainda na era atual, se molda por prerrogativas classicistas e elitistas. Assim como propunha Oiticica, a arte de Vik requer uma participação popular que caminha rumo à subversão da arte que só deseja existir para ser contemplada sem máculas. As criações de Vik Muniz apontam para uma série de questionamentos sobre o papel do artista na contemporaneidade, que, sob seu ponto de vista, está intrinsecamente ligado a sua função social. Fischer define

\begin{abstract}
A arte pode levar o homem de um estado de fragmentação a um estado de ser íntegro, total. A arte capacita o homem para compreender a realidade e o ajuda não só a suportá-la como a transformá-la, aumentando-lhe a determinação de torná-la mais humana e mais hospitaleira para a humanidade. A arte é uma realidade social. A sociedade precisa do artista, este supremo feiticeiro, e tem o direito de pedir-lhe que ele seja consciente de sua função social. Mesmo o mais subjetivo dos artistas trabalha em favor da sociedade. Pelo simples fato de descrever sentimentos, relações e condições que não haviam sido descritos anteriormente [...], representa um impulso na direção de uma nova comunidade cheia de diferenças e tensões, na qual a voz individual não se perde em uma vasta unissonância. (FISCHER, 1987, p. 56, 57)
\end{abstract}

Como argumenta Fischer o artista é o verdadeiro feiticeiro, alquimista, "antena da raça”, tal qual defende Pound. A verdadeira criação implica a manifestação de um espírito inquietante e uma ação transformadora que liberta a vida e o indivíduo de seu estado passivo. A arte é transformadora principalmente na medida em que, por meio de sua ação eminentemente crítica, altera, modifica a realidade social.

Em "Melchior, o mais melhor", Calcanhotto dá prolongamento ao seu modo de composição desenvolvido em “O poeta aprendiz”. Há até certa semelhança estética entre o visual do menino construído para ilustrar o poema de Vinícius de Moraes e Melchior. Ambos são magros, brancos e com cabelos meio desgrenhados. Nota-se que a artista não trabalha minuciosamente as expressões 
faciais de Melchior: dois pequenos riscos representam os olhos do menino que se movem em sutis movimentos de expansão e retração, enquanto os lábios não apresentam nenhum traçado. As cores se alternam nas páginas em fluxos rosas, azuis, amarelos e verdes que dão complementariedade e vivacidade à expressão dos personagens em distintas situações. Destacam-se o figurino e o cenário criados para a festa de aniversário do personagem Mário Tanaka, que remetem às imagens do livro “O pequeno príncipe”, de Saint Exupery. Duas imagens, uma ao lado da outra, revelam o menino Melchior em dois momentos-movimentos. A maior traz o personagem de frente dançando sobre um fundo lilás salpicado de pontinhos brancos que fazem analogia aos planetas visitados pelo Pequeno Príncipe. A imagem ao lado mostra o mesmo cenário e figurino, porém com um movimento mais ousado que mostra a versatilidade coreográfica de "Melchior, o mais melhor”, que se apoia somente sobre uma das mãos pousada no chão. O texto de Vik Muniz descreve:

Mais tarde, teve a festinha de aniversário do Mário Tanaka. Na hora da dança, Melchior, para surpresa de todos, dançou melhor que um Frédi Asteiri. Ele saltava, dava piruetas e sapateava como ninguém nunca havia visto. No início, sua performance arrancou grandes aplausos do público, mas aos poucos as pessoas cansaram de bater palmas e foram todas comer bolo e brigadeiro. Melchior dançava tão bem e ocupava o salão de tal forma que ninguém ousava ficar por ali, quanto mais dançar. (MUNIZ, 2011, p. 31)

O texto de Vik e as imagens de Calcanhotto se complementam; uma imagem pode ser considerada ilustração a partir do momento em que o seu objetivo se torna confirmar ou exemplificar o conteúdo de um livro, jornal, revista ou qualquer outro tipo de publicação. A ilustração também pode ser uma imagem que substitui um texto, que acrescenta informações ou que até mesmo o questiona.

“Maré” retoma a poética das águas iniciada no álbum “Maritmo”, em que, com um aprimorado trabalho sonoro e visual, a artista canta o imaginário dos mares e suas sereias. Estes dois CDS fazem parte de uma trilogia anunciada, mas não confirmada por Calcanhotto:

Não sei quando será finalizada e não sei dizer se haverá, de fato, o terceiro. Não criei uma trilogia para que isso vire um compromisso, uma obrigação. Minha relação com o tema mar é contemplação, não diria silenciosa, já que fiz dois álbuns a respeito, mas é fascinante pra mim. No mar você não tem certeza de nada, como na vida, aliás. (Calcanhotto ainda uma garotinha. Jornal da tarde: $13 / 06 / 2008)$ 
É uma trilogia maritima, o mar é o elo. O mar de Caymmi, de Melville, de Mário Peixoto. O mar literário, artificial, metafórico, além do quântico. No Maritmo eu tinha ideias mais definidas para as levadas e climas musicais do que tive no Maré, onde preferi que as coisas, literalmente, fluíssem. Para o terceiro não tenho as canções, só o desejo de realizá-lo, musicalmente não sei o que vai acontecer, não tenho programa. (www.adrianacalcanhotto.com.br)

A imprevisibilidade da vida maritima, aspecto pelo qual a cantora demonstra possuir um fascínio, é o que parece constituir a questão chave que impulsiona a criação do repertório do show e sua estética, parcialmente adaptados para o disco, que, devido a limitações inerentes ao seu próprio formato, jamais será igual ao show. O figurino construído por Gilda Midani para o espetáculo consiste em dois amplos mantos, um inteiramente cinza e outro vermelho que se alternam no decorrer da apresentação. O de cor cinza, utilizado durante a maior parte do show, se harmoniza com a intenção do cenário e das luzes que aludem ao fundo do mar. As luzes ocupam um espaço fundamental em "Maré", criando a atmosfera do palco que sugere um clima meio onírico através da insinuação do movimento das águas do mar. Há uma sinuosidade sugerida na iluminação que atua como se estivesse situada em dimensões vistas no constante ir e vir das ondas do mar entoado por Calcanhotto. O mar serve como matéria para inquietações imaginárias que explicitam movimento, música, fluxo, destino, memória, desejo música, ironia, melancolia, morte. O cenário de Hélio Eichbauer segue um conceito minimalista como de costume nas produções da artista. O fundo azul é composto de pinturas sobre véus transparentes, que reproduzem animais marinhos, como peixes, golfinhos e cavalos-marinhos extraídos de afrescos da civilização micênica, do século 12 a.c. Pequenas conchas ocupam o chão de forma aleatória, enquanto uma grande concha faz alusão ao veículo de transporte com o qual a deusa mitológica Tétis fez suas viagens pelo mundo. Tétis é filha de Urano, céu, e Gaia, terra. Seu nome grego significa ama, nutriz por ser a deusa da água. De acordo com uma crença antiga, sua existência entrava na formação de todos os corpos. Esta deusa personifica a fecundidade do mar, tanto que, na lenda, ela casou-se com o seu irmão Oceano e foi mãe de três mil rios e três mil ninfas, denominadas Oceânidas. Tétis costuma ser representada sobre um carro em forma de uma divina concha extremamente branca. É comum ver a construção da imagem da deusa Tétis sendo guiada por seu carro-concha puxado por cavalos marinhos brancos que flutuam sobre a superfície das águas. 
A capa do encarte consiste num dos mais belos projetos gráficos da discografia da artista: mostra uma imagem do rosto de Calcanhotto adulterada pelo uso da maquiagem que a transforma em mulher sereia, Tétis, Calipso, Iemanjá. Assombreados em tons de azul e violeta pintam os lábios, pálpebras, sobrancelhas e maxilares, construindo uma espécie de máscara que edifica um jogo de identidades camufladas. Calcanhotto é mulher e peixe no espaço imaginário da tinta e do papel, do som e das palavras. A foto-desenho da cantora/sereia, em seu caráter propositalmente impreciso pelas manchas de azul que o percorrem, traz à tona a grande questão que envolve a existência das sereias, que é a sua natureza ambígua. Essas mulheres-peixes são seres híbridos que se tornam muito belos diante do reflexo da formosura feminina. Poderíamos dizer que são a alteridade dos seres femininos que se dissimulam em semelhança, constituem o outro por sua natureza, sedução e força dissimuladora.

Iemanjá, conhecida como deusa do mar, é um dos arquétipos mencionados no repertório do CD através da gravação que Calcanhotto faz da canção "Sargaço mar”, de Dorival Caymmi:

\author{
Deusa de amor, deusa do mar \\ Vou me atirar, beber o mar \\ Alucinado, desesperar \\ Querer morrer para viver \\ Com Iemanjá \\ Iemanjá, Odoiá \\ Iemanjá, Odoiá \\ Iemanjá, Odoiá (In: CALCANHOTTO, 2008)
}

Iemanjá é ligada às profundidades obscuras e abissais dos mares e carrega em si dois fortes atributos, um de mãe e outro de amante. Sua imagem de sereia remete à sua condição de mulher sexuada, feminina, enquanto a de mãe é representada pela mulher branca de imagem angelical, portadora de longos cabelos pretos e vestido azul. O mar e Iemanjá podem ser vistos como instâncias geradoras de vida e também de morte. Sob essa perspectiva , compreende-se o mar como um útero gerador de vida e, ao mesmo tempo, simbolicamente, na dimensão do inconsciente psíquico, uma profundeza desconhecida, misteriosa, perigosa, descomunal, que também extermina a vida, engolindo-a em sua imensa escuridão. Iemanjá, portanto, é a rainha deste mar povoado de sedução e armadilhas, que deseja enfeitiçar os marinheiros pelo poder de sua voz singular. 
Na "Odisséia” de Homero, o personagem Ulisses retornava a sua casa após conquistar Tróia e no caminho passou pela ilha de Capri, ilha das sereias. Ao tomar conhecimento de que qualquer homem que ouvisse o canto daquelas mulheres não resistiria e se jogaria ao mar para ser devorado por elas, decidiu colocar cera nos ouvidos dos companheiros de viagem. Mesmo assim, foi tomado por um desejo imenso de conhecer o canto das sereias e, para tanto, pediu que os companheiros o prendessem no mastro e o mantivessem contido sob qualquer hipótese. Na história de Homero vê-se o quanto o canto da sereia é irresistível e simultaneamente devastador.

Calcanhotto grava a canção "Porto Alegre”, de Péricles Cavalcanti, num tom bem humorado, dando ênfase a uma levada rítmica em que se sobressai a descontração. Os versos da canção se referem ao segundo canto da Odisséia de Homero, episódio que se refere à tentativa de Ulisses em resistir amarrado a um mastro ao canto das sereias. O compositor, ironicamente, brinca com o desejo do personagem, que, ao chegar à praia, se deixa levar pela sedução do canto da sereia e se entrega ao ritmo contagiante do "calipso":

\author{
Amarrado num mastro \\ Tapando as orelhas \\ Eu resisti \\ Ao encanto das sereias \\ Eu não ouvi \\ O canto das sereias \\ Eu resisti \\ Mas chegando à praia \\ Não fiz nada disso \\ Então caí \\ Nos braços de Calipso \\ Eu sucumbi \\ Ao encanto de Calipso \\ Não resisti \\ Depois disso eu não tive \\ Nenhum outro vício \\ Senão dançar \\ Ao ritmo de Calipso \\ Pois eu caí \\ Nas graças de Calipso \\ Não resisti \\ Ao encanto de Calipso \\ Só sei dançar
}


Ao ritmo de Calipso

Calipso

Desde então eu não tive

Nenhum outro vício

Senão dançar

Ao ritmo de Calipso

pois eu caí

Nas graças de Calipso

Não resisti

Ao encanto de Calipso

Só sei dançar

Ao ritmo de Calipso

Calipso (In: CALCANHOTTO, 2008)

“Porto Alegre” é a canção mais descontraída do álbum, que traz até em seu nome um caráter lúdico. $\mathrm{O}$ arranjo e a interpretação da artista destacam a intenção satírica da letra de Péricles Cavalcante, que transforma uma história permeada de sedução e mistério em pura fruição descompromissada. Intencionalmente Calcanhotto no álbum "Maré”, mistura várias percepções do mar, que pode ser ácido, doce, misterioso, alegre, sensual e perigoso.

O mar anunciado pela compositora no álbum “Maré” apresenta-se em uma linguagem poética, pictórica e sonora. No verso da capa do encarte, a ênfase imagética se transfere do rosto para os pés; sendo assim a artista novamente elabora um jogo que visa confundir as identidades. A cauda da sereia Iemanjá passa a ser substituída pelos pés de Calcanhotto, manchados de azul. Quem seria então essa sereia, mulher que deseja seduzir o ouvinte pela beleza de sua voz? O manto cinza utilizado pela cantora durante a temporada de shows de "Maré" é reproduzido no encarte numa imagem sua de corpo inteiro. A textura do tecido evidenciada na foto revela a intenção de demonstrar maleabilidade, como se a cantora evoluísse em sintonia com o movimento das águas. Esse figurino também remete a imagem popularmente difundida da Deusa Iemanjá com caracteres humanos, ou seja, sem a parte da cauda que a caracterizaria como sereia.

Retomando a análise da capa do CD, vemos que a face de Calcanhotto, Tétis, Iemanjá, se sobressai por sua ambiguidade que sugere várias referências. O enquadramento do olhar, incisivo em direção à frente, e as manchas de tinta azul que envolvem várias partes do rosto sugerem a figura da sereia, mas não indicam com precisão sua identidade. "Maré”, a canção que abre o $C D$, menciona em seus 
versos os diversos mares que ressurgem após o álbum "Maritmo”. A linguagem das águas, suas cores e movimentos são cantados por Calcanhotto:

\author{
Mais uma vez \\ vem o mar \\ se dar \\ como imagem \\ Passagem \\ do árido à miragem \\ Sendo salgado \\ gelado \\ ou azul \\ Será só linguagem \\ Mais uma vez \\ vejo o mar \\ voltar \\ como imagem \\ Passagem \\ de átomo a paisagem \\ Estando emaranhado \\ verde azul \\ Será ondulado \\ Irado emaranhado \\ verde azul \\ Será ondulado (In: CALCANHOTTO, 2008)
}

O jogo que visa confundir as identidades em "Maré" novamente mostra o uso da máscara, uma constante no decorrer dos trabalhos de Calcanhotto. É recorrente a existência de um processo de mascaramento no design das capas dos CDS da compositora. Em “Cantada” há uma fragmentação do rosto que oculta a identidade da artista, já que na capa aparecem somente seus lábios em destaque. Em "Partimpim1” máscaras de formas distintas reproduzem um ideal estético que dialoga com a arte pop, estabelecendo um jogo lúdico que brinca com identidades. Em "Partimpim2" a artista retoma o uso da máscara evidenciado na capa de “’Partimpim 1”, que dá legitimação à existência de seu heterônimo Partimpim.

O uso da máscara vem de tempos remotos e data da pré-história. As de feição primitiva expressavam uma aparência grotesca, sombria, pois tinham o propósito de espantar os maus espíritos ligados às crenças de alguns povos. Os povos gregos e egípcios na antiguidade construíam máscaras mortuárias que consistiam em homenagens póstumas a pessoas ilustres que ficavam imortalizadas 
como heróis. Posteriormente, na Grécia antiga, surgiram as máscaras teatrais, utilizadas para substituir o rosto original do ator, amplificar sua voz e definir os caracteres. Elas serviam para o ator figurar aos espectadores os tipos tradicionais da tragédia e da comédia, além de alterar sua extensão de voz. O maior inconveniente causado pelo uso da máscara era a rigidez que impunha ao rosto, tornando às vezes complicado o desempenho do ator que, por exigência do texto, necessitava passar de um sentimento a outro. Sendo assim uma máscara só tornava-se insuficiente para abarcar todas as expressões faciais almejadas por um ator.

Calcanhotto, por meio do uso de máscaras, dá margem a uma amplitude criativa que legitima a invenção de uma nova identidade, concretizada no seu heterônimo Partimpim. Sereia, Partimpim, gladiador, em cada máscara a cantora desenvolve um apurado trabalho plástico que se relaciona dialogicamente com obras e artistas do universo contemporâneo. Seus figurinos e encartes comumente fazem referência a artistas plásticos como Helio Eichbauer, Mondrian, Helio Oiticica e Andy Wahrol. Esses contínuos diálogos pictóricos mostram que, de acordo com o pensamento da cantora, sua performance vai muito além do ato de cantar com um microfone em punho; ela se preocupa com tudo o que reveste uma apresentação, como luzes, figurino e roteiro.

"Micróbio do samba” é um álbum que traz uma proposta ousada da artista, visto que mais uma vez objetiva inquietar/ provocar o ouvido do receptor. Como aponta o próprio título, este disco sugere um trabalho inteiramente dedicado ao samba; porém, no desenrolar de nossa audição, constatamos que o formato tradicional, que define o arranjo, concepção e interpretação do gênero, encontra-se quase inteiramente transformado. Calcanhotto, intencionalmente, desestrutura o “jeito sambista” de compor e cantar samba ao mesmo tempo que traz implícita uma contínua reverência àqueles que foram responsáveis pela consolidação do gênero.

A elaboração visual do encarte do CD dá continuidade à eleição da cantora por uma estética que valoriza qualidades e detalhes pictóricos. Sua recorrente preferência por artistas plásticos contemporâneos é reafirmada na capa de “Micróbio do samba”, que expõe uma obra do artista plástico Luiz Zerbini. Sua criação reduzida para a pequena dimensão do encarte não se restringe apenas ao espaço exterior da capa; espalha-se por todas as páginas em jogos de cores que 
colocam em destaque pigmentos vermelhos, laranjas, marrons e pretos. Uma estética abstrata define a proposta do trabalho do artista, porém podemos entrever, através de uma profusão de distintas formas circulares e de colorações variadas, uma analogia, buscada por Calcanhotto, a uma forma celular que remeteria possivelmente a um micróbio, o "micróbio do samba”. Os círculos em tamanhos distintos que se distribuem pelas páginas do encarte metaforizam em forma pictórica a invasão do "micróbio sonoro”. Confetes, serpentinas e muita formas arredondadas se alternam entre sugestões de movimentos e misturas. As cores são vivas, mas trazem subjacente uma intenção que deixa entrever uma espécie de "alegria triste”, como um complemento pictórico da canção “Tão chic”:

Tão chic, tão cheia de si

tão triste, me ouça

a vida voa baixinho

cê vai ver, já é

eu quero teu amor eterno

até a quarta-feira (IN: CALCANHOTTO, 2011)

Um dos registros mais emocionantes de "Micróbio vivo" encontra-se no momento em que Calcanhotto interpreta “Tão chic”, música de sua autoria, uma espécie de homenagem às marchinhas de carnaval em tom de delicada melancolia. Chuvas de confete vão caindo-lhe lentamente em reflexos de cores, enquanto ela vai cantando os versos da canção. A ideia transmitida na imagem cênica é semelhante à que trazem as folhas do encarte. A alegria desponta ao lado de uma certa reverência quase saudosista, mas que ganha vigor por seu caráter inventivo.

Até o momento, este último CD de Calcanhotto dá continuidade ao seu diálogo elaborado com as artes plásticas, iniciado no disco "Enguiço”. Fusões de cores e experimentalismos plásticos fizeram parte de quase a totalidade de encartes analisados por nós no decorrer deste capítulo. 


\section{Conclusão}

No percurso desta tese, um de nossos principais objetivos foi proceder à análise do desenvolvimento vocal da cantora Adriana Calcanhotto à maneira como ela imprime uma marca rasurante às suas interpretações. Nosso percurso de análise das rasuras elaboradas por Calcanhotto, pautou-se pela aplicação das ideias formuladas por Júlio Diniz. De acordo com o autor, o processo de rasura pode ser verificado por meio de um intercâmbio com cinco círculos semióticos: a tradição sentimental e exagerada da música brasileira nos anos 40 e 50, o distúrbio geracional e sonoro das guitarras e cabelos compridos da Jovem Guarda, o minimalismo das ricas formas poéticas, harmônicas e melódicas da Bossa Nova e o engajamento barulhento e transformador das músicas de protesto.

Avaliamos o desempenho vocal de Calcanhotto em várias canções, desde seu disco de estréia, "Enguiço", até o mais recente, "O micróbio do samba”. Vimos como este disco inicial é destoante em relação às propostas dos trabalhos que o sucedem. A partir do cd “A fábrica do poema”, a artista marca sua assinatura enquanto cantora, revelando a proposta cool que irá seguir durante os demais discos. A ênfase na expressão cênica, que a princípio a deixa numa espécie de entrelugar entre a cantora e a atriz, passa a ceder espaço para a cantora, que se preocupa com mais detalhes na inflexão da voz. Para a condução de uma reflexão mais profunda sobre os meandros da voz, utilizamos como base teórica as idéias de Paul Zumthor. Para esclarecer numa perspectiva prática o percurso vocal da artista, dirigimo-nos às idéias concebidas por Felipe Abreu, técnico vocal de Adriana Calcanhotto.

Analisamos a atuação performática de Calcanhotto e a forma como esta se estabelece fundamentalmente em suas performances cênicas, em shows que demonstram uma forte relação com outras categorias artísticas, como a literatura e as artes plásticas. Vimos como, em suas atuações no palco, a cantora dá primazia a performances minimalistas, que não dizem respeito exclusivamente ao desempenho do canto, mas também à concepção visual dos cenários e figurinos, conforme demonstram o show "Público" e "Micróbio do samba". 
O diálogo realizado com as artes plásticas se faz presente em toda a trajetória de Calcanhotto. Por meio da análise dos encartes dos discos da cantora, constatamos como esta artista trabalha com vários diálogos artísticos, deixando em destaque a vanguarda composta por criadores como Hélio Oiticica, Mondrian, Andy Wahrol, Hélio Eichbauer, entre outros.

É destacável como a literatura ocupa posição de destaque em todo o percurso criativo de Calcanhotto. Ela põe música em poemas de Waly Salomão, Ferreira Gullar e Mário de Sá Carneiro, trabalhando continuamente entre os pilares da tradição e da vanguarda. A literatura ergue-se como uma espécie de fio condutor de suas criações; é através do tratamento concedido à palavra, aos versos, que primeiramente esta artista fomenta sua inventividade e suas relações com o universo das artes. Calcanhotto transcende o ofício de musicar poemas e também participa do mundo literário elaborando desenhos para obras como "O poeta aprendiz”, de Vinícius de Moraes, e “Melquior, o mais melhor”, obra em parceria com o artista plástico Vik Muniz.

A criação do hetrônimo Partimpim é uma máscara-disfarce inventada pela artista para dar vazão ao seu trabalho dedicado ao universo infantil. A invenção de um heterônimo consiste numa atitude inédita no cenário da música popular brasileira, visto que essa atitude havia sido tomada por Chico Buarque apenas com o intuito de burlar a censura no contexto ditatorial. Como detectamos em nossa tese, Partimpim é um trabalho de Calcanhotto absolutamente distinto dos demais, dedicado às crianças, mas que não se rende a uma linguagem que subestime a inteligência infantil. Os arranjos dão relevância ao aspecto lúdico das canções, intensificado por meio de uma diversidade de experimentações sonoras realizadas com objetos inusitados que dão destaque à inventividade.

Como pudemos constatar ao longo de nossa pesquisa, a produção musical de Adriana Calcanhotto traz como grande diferencial seu amplo caráter dialógico que abrange relações com outras modalidades artísticas, como a literatura e artes plásticas. Calcanhotto é uma artista que pensa o ofício criativo e esta reflexão se torna evidente por meio de seus trabalhos que mostram uma acentuada postura crítica. 


\section{Bibliografia}

ABRAMOVICH, Fanny. Literatura infantil. São Paulo: Scipione, 1989.

ADORNO, Theodor. O fetichismo na música e a regressão da audição. In: Textos escolhidos. São Paulo: Editora Nova Cultural, 1999.

AGAMBEN, Giorgio. O que é o contemporâneo? e outros ensaios. Chapeco: Argos, 2009.

ALBIN, Ricardo Cravo. O livro de ouro da MPB. Rio de Janeiro: Ediouro, 2003.

AMARAL, Euclides. Alguns aspectos da MPB. Rio de Janeiro: Esteio Editora, 2010.

ANDRADE, Mário de. Aspectos da música brasileira. São Paulo: Martins, 1975.

Editora, 1962.

Ensaio sobre a música brasileira. São Paulo: Livraria Martins

. Introdução à estética musical. São Paulo: Hucitec, 1995.

ANDRADE, Oswald de. Obras completas. Rio de Janeiro: Civilização Brasileira, 1986.

ANDRADE, Carlos Drummond de. Reunião. Rio de Janeiro: José Olympio, 1978.

ARGAN, Giulio Carlo. Arte moderna. São Paulo: Companhia das letras, 1992.

ARIÈS, Philippe. História social da criança e da família. Rio de Janeiro: LTC, 1981.

BACHELARD, Gaston. A poética do devaneio. São Paulo: Martins Fontes, 1988.

.A água e os sonhos. Ensaio sobre a imaginação da matéria. São Paulo: Martins Fontes, 1997.

BAHIANA, Ana Maria. Nada será como antes. Rio de Janeiro: Civilização Brasileira, 1980.

BAKHTIN, Mickail. Problemas da poética de Dostoiévski. Rio de Janeiro: Ed. Forense Universitária, 2002.

BARONIAN, Jean- Baptiste. Baudelaire. Porto Alegre:L\&PM, 2010.

BARTHES, Roland. O prazer do texto. São Paulo: Perspectiva, 2002. O óbvio e o obtuso. Rio de Janeiro: Nova fronteira, 1990. 
A câmara clara. Rio de Janeiro: Nova Fronteira, 1980.

BARROS, Manoel de. Obra completa. São Paulo: Leya Brasil, 2008.

BATCHELOR, David. Minimalismo. São Paulo: Cosac \& Naif, 1991.

BAUMAN, Zygmunt. Modernidade líquida. Rio de Janeiro: Jorge Zahar, 2001.

Amor líquido. Rio de Janeiro: Jorge Zahar, 2004.

BENEVIDES, Ricardo de Sá e. Atividade musical e subjetividade alternativa in: VILLAÇA, Nízia; GÓES, Fred; KOSOVSKI, Ester (orgs). Que corpo é esse?. Rio de Janeiro: Mauad, 1999.

BENJAMIN, Walter. Reflexões sobre a criança, o brinquedo e a educação. São Paulo: Duas Cidades, 2002.

Brasiliense, 1994.

Charles Baudelaire: um lírico no auge do capitalismo. São Paulo:

A obra de arte na era de sua reprodutibilidade técnica. Obras escolhidas: Magia e técnica, arte e política. São Paulo: Brasiliense, 1987.

BERMAN, Marshall. Tudo que é sólido desmancha no ar. São Paulo Companhia das Letras, 1986.

BOLLON, Patrice. A moral da máscara. Rio de Janeiro: Rocco, 1993.

BOSCO, Francisco. Dorival Caymmi. São Paulo: Publifolha, 2006.

BOUCIER, Paul. História da dança no ocidente. São Paulo: Martins Fontes, 1987.

BRAGA, Paulo. A arte de Hélio Oiticica. São Paulo: Perspectiva, 2008.

BRITO, Antônio Carlos de. Lero-Lero. Rio de Janeiro: 7 Letras, 2002.

BROWNBRIDGE, Sue. Andy Warhol. Barcelona: Polígrafa, 2005.

BUARQUE, Chico. Ópera do malandro. São Paulo: Círculo do livro, 1978.

CABRAL, Sérgio. Antônio Carlos Jobim: uma biografia. Rio de Janeiro: Lumiar, 1997.

CABRERA, Lydia. Iemanjá e Oxum. São Paulo: Edusp, 2004.

CALADO, Carlos. Tropicália- A história de uma revolução musical. São Paulo: Editora 34, 1997.

CAMPO, Giuliano. Trabalho de voz e corpo de Zygmunt Molik: o legado de Jerzy Grotowski. São Paulo: É Realizações, 2012. 
CAMPOS, Augusto de. Balanço da bossa e outras bossas: antologia crítica da moderna música popular brasileira. São Paulo: Perspectiva, 1968.

CAMPOS, Haroldo de. Metalinguagem e outras metas: ensaios de teoria e crítica literária. São Paulo: Perspectiva, 1992.

CANCLINI, Nestor. Consumidores e cidadãos. Rio de Janeiro: Editora da UFRJ, 2005.

Paulo, 1998.

CARREIRA, André, VILLAR, Fernando Pinheiro e GRAMMONT de Guiomar (orgs). Mediações performáticas latino-americanas II. Belo Horizonte: UFMG, 2004.

CARVALHO, Tania. Irene Ravache: caçadora de emoções. São Paulo: Imprensa Oficial do Estado de São Paulo, 2004.

CASTRO, Ruy. Chega de saudade: a história e as histórias da Bossa Nova. São Paulo: Companhia das Letras, 1990.

CAUQUELIN, Anne. Arte contemporânea: uma introdução. São Paulo: Martins Fontes, 2005.

CAVALCANTE, Berenice, STARLING, Heloisa, EISENBERG, José (orgs.). Decantando a República. Rio de Janeiro: Nova Fronteira/São Paulo: Fundação Perseu Abramo, 2004.

CAVARERO, Adriana. Vozes plurais. Filosofia da expressão vocal. Belo Horizonte: Editora UFMG, 2011.

CHEDIAK, Almir. Songbook Bossa Nova. Rio de Janeiro: Lumiar, 1990.

COELHO, Frederico e CAETANO, Daniel. Encontros: Tom Jobim. Rio de Janeiro: Beco do Azougue, 2011.

COHEN, Renato. Performance como linguagem. São Paulo: Perspectiva, 2007.

COHN, Sergio e COELHO, Frederico (org). Tropicália- encontros. Rio de Janeiro: Beco do Azougue, 2008.

COSTA, Jurandir freire. Sem fraude nem favor: estudos sobre o amor romântico. Rio de Janeiro: Rocco, 1998.

DACYNGER, Ken. Técnicas de edição para cinema e vídeo: história, teoria e prática. Rio de Janeiro: Elsevier, 2003.

DELEUZE, Gilles; GUATTARI, Félix. O que é a filosofia? São Paulo: Ed 34, 2005. 
DINIZ, Julio César Valladão. O recado do morro - criação e relação na música popular brasileira. In: Literatura e Cultura. Rio de Janeiro: PUC-Rio, 2003.

Sentimental demais: a voz como rasura. In: DUARTE, Paulo Sergio e NAVES, Santuza Cambraia (orgs.). Do samba-canção à tropicália. Rio de Janeiro: Relume-Dumará / FAPERJ, 2003.

A voz como construção identitária. In: MATOS, Cláudia Neiva et ali (orgs). Ao encontro da palavracantada - poesia,música e voz. Rio de Janeiro: 7 Letras, 2001.

A voz múltipla de Narciso (uma leitura do projeto estético de Caetano Veloso). In: Toward socio-criticism:luso-brazilian literatures, Tempe: Arizona State University Press, 1991.

- Modulando a dissonância - Música e letra. Rio de Janeiro: Departamento de Letras/ Puc, 1995.

DIAS, Rosa Maria. Nietzche e a música. Rio de Janeiro: Imago, 1994.

DUARTE, Paulo Sergio e NAVES, Santuza Cambraia (orgs.). Do samba-canção à tropicália. Rio de Janeiro: Relume-Dumará / FAPERJ, 2003.

ELIOT, T.S. Ensaios. São Paulo: Art Nova, 1989.

Tradition andthe individual talent. London: Faber, 1975.

FAOUR, Rodrigo. Dolores Duran. A noite e as canções de uma mulher fascinante. Rio de Janeiro: Record, 2012.

FAVARETTO, Celso. Tropicália: alegoria, alegria. São Paulo: kairós, 1979.

FERNANDES, Rinaldo de (org). Chico Buarque do Brasil: textos sobre as canções, o teatro e a ficção de um artista brasileiro. Rio de Janeiro: Garamond, 2004.

FERRAZ, Eucanaã (org). Letra só. Caetano Veloso. São Paulo: Companhia das Letras, 2003.

FIGUEIREDO, Luciano (org.). Cartas - Lygia Clark e Hélio Oiticica. Rio de Janeiro: Editora da UFRJ, 1998.

FILHO, Cesar Oiticica e VIEIRA, Ingrid (org). Encontros - Helio Oiticica. Rio de Janeiro: Beco do Azougue, 2009.

FINNEGAN, Ruth. O que vem primeiro: o texto, a música ou a performance? In:NEIVA de MATOS, Claudia; TRAVASSOS, Elizabeth; TEIXEIRA DE MEDEIROS, Fernanda. Palavra cantada: ensaios sobre poesia, música e voz. Rio de Janeiro: 7 letras, 2008.

FISCHER, Ernst . A necessidade da arte. Rio de Janeiro: 9 Editora, 1987. 
FOUCAULT, Michel. As palavras e as coisas. São Paulo: Martins Fontes, 1999.

GAGNEBIN, Jeanne Marie. História e narração em Walter Benjamin. São Paulo; Perspectiva, 1986.

GARCIA, Walter. Bim Bom: a contradição sem conflitos de João Gilberto. São Paulo: Paz e Terra, 1999.

Corpo, mídia e representação. Estudos contemporâneos. São Paulo: Pioneira Thomson Learning, 2005.

GIUMBELLI, Emerson, DINIZ, Júlio Cesar Valladão, NAVES, Santuza Cambraia (orgs). Leituras sobre música popular: reflexões sobre sonoridades e cultura. Rio de Janeiro: 7 letras, 2008.

GLUSBERG, Jorge. A arte da performance. São Paulo: Perspectiva, 2009.

GOETHE-INSTITUT. Teatrodanza hoy: treinta anos de historia de la danza alemana. Kallmeyersche: Hannover, 2000.

GOLDBERG, RoseLee. A arte da performance. Do futurismo ao presente. São Paulo: Martins Fontes, 2006.

GOMES, Dias e GULLAR, Ferreira. Dr. Getúlio, sua vida e sua glória. Rio de Janeiro: Civilização Brasileira, 1968.

HELD, Jacqueline. O imaginário no poder: as crianças e a literatura fantástica. São Paulo: Summus, 1980.

HOLLANDA, Chico Buarque de. Chapeuzinho amarelo. Rio de Janeiro: José Olympio, 1997.

HOLLANDA, Heloísa Buarque de. Impressões de viagem - CPC, vanguarda, desbunde, 1960/1970. São Paulo: Brasiliense, 1981.

Cultura em trânsito. Rio de Janeiro: Aeroplano, 2000.

HUIZINGA, Johan. Homo ludens. São Paulo: Perspectiva, 1980.

JOLY, Martine. Introdução a análise da imagem. Campinas: Papirus, 1996.

LEAL, Bruno Souza. A poesia que a gente vive, talvez. IN: GUIMARAES, César e MENDONÇA, Carlos Camargos (orgs) . Comunicação e experiência estética, Belo Horizonte: Editora UFMG, 2006.

LEJEUNE, Philippe. O pacto autobiográfico. Belo Horizonte: Ed. UFMG, 2008.

LELOUP, Jean Yves. O corpo e seus símbolos: uma antropologia essencial. Petrópolis: Vozes, 1998.

LOPES, José de Oliveira. A voz, a fala, o canto. Brasília: Thesaurus, 2011.

LYOTARD, J.F. O pós moderno. Rio de Janeiro: José Olympio,1993. 
MACIEL, Luiz Carlos. Geração em transe - Memórias do tempo doTropicalismo. Rio de Janeiro: Nova Fronteira, 1996.

MACONIE, Robin. Stockhausen sobre música-palestras e entrevistas compiladas. São Paulo: Madras, 2009.

MARTINS, Wilson. O modernismo. São Paulo: Cultrix, 1977.

MATOS, Cláudia Neiva de; MEDEIROS, Fernanda Teixeira de; TRAVASSOS, Elizabeth (orgs.). Ao encontro da palavra cantada - poesia, música e voz. Rio de Janeiro: 7 Letras, 2001.

Janeiro: 7 Letras, 2008.

MATOS, Cláudia. Acertei no milhar: malandragem e samba no tempo de Getúlio.Rio de Janeiro: Paz e Terra,1982.

MATOS, Maria Izilda Santos de. Dolores Duran: experiências boêmias em Copacabana nos anos 50. Rio de Janeiro: Bertrand Brasil, 1997.

MCLUHAN, Marshall. Os meios de comunicação como extensões do homem. São Paulo: Cultrix, 1969.

MELIM, Regina. Performance nas artes visuais. Rio de Janeiro: Jorge Zahar, 2008.

MELLO, José Eduardo Homem de. Música popular brasileira. São Paulo: EdUSP, 1976./

Eis aqui os Bossa Nova. São Paulo: Martins Fontes, 2008.

MOLES, Abraham. O kitsch. São Paulo: Perspectiva, 1975.

MORAES, Vinicius de. Poesia completa e prosa. Rio de Janeiro: Lacerda Editores, 2008.

O poeta aprendiz. São Paulo: Companhia das letrinhas, 2003.

MOURA, Roberto M. Sobre cultura e mídia. São Paulo: Irmãos Vitale, 2002.

MUNIZ, Vik. Melchior, o mais melhor. Rio de Janeiro: Cobogó, 2011.

NAVES, Santuza Cambraia; COELHO, Frederico Oliveira; BACAL, Tatiana (orgs.). A MPB em discussão. Belo Horizonte: Editora da UFMG, 2006.

NAZARIO, Luiz e FRANCA, Patricia (org). Concepções contemporâneas da arte. Belo Horizonte: Editora da UFMG, 2006.

NESTROVSKI, Arthur (org). Música popular brasileira hoje. São Paulo: Publifolha, 2002. 
Publifolha, 2007.

(org). Lendo música: 10 ensaios sobre 10 canções. São Paulo:

OSTROWER, Fayga. Criatividade e processos de criação. Cidade: Editora, 1999.

PAZ, Octavio. Os filhos do barro. Rio de Janeiro: Nova Fronteira, 1984.

O arco e a lira. Rio de Janeiro: Nova Fronteira, 1982.

PERRONE, Charles. Letras e letras da MPB. Rio de Janeiro: Elo, 1988.

PLATÃO e FIORIN. Lições de texto. Leitura e redação. São Paulo: Ática, 2001.

PONTY, Maurice. Fenomenologia da percepção. São Paulo: Martins Fontes, 1996.

POUND, Ezra. ABC da literatura. São Paulo: Cultrix, s/d.

READ, Herbert. Arte e alienação: o papel do artista na sociedade. Rio de Janeiro: Zahar, 1983.

REICH, Steve. Writings about Music. Halifax: Nova Scotia College of Art and Design, 1974.

RITO, Lucia. Fernanda Montenegro em o exercício da paixão. Rio de Janeiro: Rocco, 1990.

RODRIGUES, Carlos Leoni. Letra, música e outras conversas. Rio de Janeiro: Gryphus, 1995.

SALOMÃO, Waly. Babilaques: alguns cristais clivados. Rio de Janeiro: Contra Capa Livraria/Kabuki Produções Culturais, 2007.

SANDRONI, Carlos. Feitiço decente. Transformações do samba no Rio de Janeiro. Rio de Janeiro: Jorge Zahar, 2001.

SARLO, Beatriz. Cenas da vida pós-moderna. Rio de Janeiro: Editora UFRJ, 1997.

SANT'ANNA, Affonso Romano de. Música popular e moderna poesia brasileira. Petrópolis: Vozes, 1978.

SARTRE, Jean- Paul. Sobre os móbiles de Calder. In: SARAIVA, Roberta (org). Calder no Brasil: Crônica de uma amizade. São Paulo: Cosac \& Naify, 2006.

SHUSTERMAN, Richard. Consciência corporal. São Paulo: Editora Vida e consciência, 2012.

SILVA, Armando. Álbum de família: a imagem de nós mesmos. São Paulo: Ed. SENAC/SESC-SP, 2008.

SODRÉ, Muniz. O dono do corpo. Rio de Janeiro: Mauad, 1998. 
SONTAG, Susan. Contra a interpretação. Porto Alegre: L\&PM, 1987.

SUBIRATS, Eduardo. Da vanguarda ao pós-moderno. São Paulo: Nobel, 1991.

SYLVESTER, David. Sobre arte moderna. São Paulo: Cosac Naify, 2006.

TATIT, Luiz. Todos entoam. São Paulo: Publifolha, 2007.

.O século da canção. São Paulo: Atêlie Editorial: 2004.

A canção: eficácia e encanto. São Paulo: Atual, 1986.

- Semiótica da canção (letra e música). São Paulo: Escuta, 1994.

Editora da Universidade de São Paulo, 2002.

TELES, Gilberto Mendonça. Vanguarda europeia e modernismo brasileiro. Rio de Janeiro: Vozes, 1997.

TINHORÃO, José Ramos. Pequena história da música popular: da modinha à canção de protesto. Petrópolis: Vozes, 1974.

Música popular - um tema em debate. Rio de Janeiro: JCM, 1996.

. Crítica cheia de graça. São Paulo: Empório do livro, 2010.

Os sons dos negros no Brasil - cantos, danças, folguedos: origens.

São Paulo: Editora 34, 2008.

Cultura popular: temas e questões. São Paulo: Editora 34, 2001.

TROTTA, Felipe. Produção cultural e qualidade estética: o caso as música popular. Intercom - Sociedade Brasileira de Estudos Interdisciplinares da Comunicação. IX Congresso Brasileiro de Ciências da Comunicação da Região Nordeste - Salvador- Bahia, 2007.

VALENTE, Heloísa de Araújo Duarte. Os cantos da voz: entre o ruído e o silêncio. São Paulo: Annablume, 1999.

VELOSO, Caetano. Verdade tropical. São Paulo: Companhia das letras, 2000.

. Letra só. São Paulo: Companhia das letras, 2003.

VIANNA, Hermano. O mistério do samba. Rio de Janeiro: Zahar/UFRJ, 1995.

WINNICOTT, D.W. O brincar e a realidade. Rio de Janeiro: Imago, 1975.WISNIK, José Miguel. O som e o sentido. São Paulo: Companhia das Letras, 1989.

. Sem receita. Ensaios e canções. São Paulo: Publifolha, 2004. 
O coro dos contrários: a música em torno da semana de 22. São

Paulo: Duas cidades, 1977.

ZUMTHOR, Paul. A letra e a voz. São Paulo: Companhia das Letras, 1993.

Performance, recepção, leitura. Rio de Janeiro: Cosacnaify, s/d.

Escritura e nomadismo. São Paulo: Atêlie Editorial, 2005.

\section{Discografia}

CALCANHOTTO, Adriana. Partimpim 3. CD. Rio de Janeiro: Sony Music, 2012.

\footnotetext{
Micróbio do samba.CD. Rio de Janeiro: Sony Music, 2011.

—. Partimpim 2. CD. Rio de Janeiro: Sony Music, 2009.

—. Maré. CD. Rio de Janeiro: BMG, 2008.

—. Partimpim. CD Rio de Janeiro: BMG, 2004.

. Cantada. CD. Rio de Janeiro: BMG, 2002.

. Público. CD. Rio de Janeiro: BMG, 2000.

Maritmo. CD. Rio de Janeiro: Sony Music, 1998.

A Fábrica do Poema. CD. Rio de Janeiro: Sony Music, 1994.

. Senhas. CD. Rio de Janeiro: Sony Music, 1992.

. Enguiço. CD. Rio de Janeiro: Columbia,1990.

\section{DVDS}

CALCANHOTTO, Adriana. Público. Rio de Janeiro: Sony Music, 2009.

Partimpim. Rio de Janeiro: Sony Music, 2009.

Partimpim 2. Rio de Janeiro: Sony Music, 2010.

Micróbio vivo. Rio de Janeiro: Sony Music, 2011. 


\section{Participações em filmes e musicais}

SOLBERG, Helena. Palavra encantada. Rio de Janeiro: Biscoito Fino, 2009.

JÚNIOR, Miguel Faria. Vinicius. Rio de Janeiro: Biscoito Fino, 2005.

\section{FONTES DA WEB}

ALMIRANTE. Yes, nós temos banana. Disponível em: $<$ http://www.youtube.com/watch?v=Ou_N7ajW96I $>$ Acesso em: 21 de julho de 2012

ALVES, Francisco. Solteiro é melhor. Disponível em:

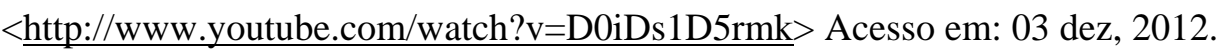

BATISTA, Wilson e LOBO, Heraldo. Emília. Disponível em: http://www.vagalume.com.br/haroldo-lobo/emiliasamba.html Acesso em: 06 de dezembro de 2012.

CALCANHOTTO, Adriana. Entrevista no programa Jô Soares. $<$ http://www.youtube.com/watch?v=mryearLwfA0\&feature=endscreen\&N $\mathrm{R}=11>$ Acesso em: 5 de dezembro de 2011.

CALCANHOTTO, Adriana. $<$ www.adrianacalcanhotto.com.br $>$ Acesso em: 14 de janeiro de 2012.

CALCANHOTTO, Adriana.Programa Umas palavras. $<$ http://www.youtube.com/watch?v=EUKZ2okmoyM> Acesso em: 24 de março de 2011.

DEBELLIAN, Marcio. Entrevista com Adriana Calcanhotto. Disponível em: $<$ http://www.youtube.com/watch?v=wrkcw6SmV38\&playnext=1\&list=PLA790D 173EBB42434\&feature=results_main> Acesso em: 5 de outubro de 2012.

HOLLANDA, Chico Buarque de. Homenagem ao malandro. Disponível em: < http://letras.mus.br/chicobuarque/45135/> Acesso em : 5 de outubro de 2012.

Programa Ensaio. Entrevista com a cantora Adriana Calcanhotto. Disponível em: $<$ https://www.youtube.com/watch?v=IZnl8xm6o3c $>$ Acesso em: 13 de julho de 2012

RODRIGUES, Lupicínio. Vingança. Disponível em: $<$ http://www.youtube.com/watch?v=ZXFginzWtFc $>$ Acesso em: 21 de julho de 2012

VELOSO, Caetano. Marcha contra a guitarra. Disponível em: <http://poesiampb.blogspot.com.br/2011/12/marcha contraguitarratropicalismo.html> Acesso em: 22 de junho de 2012. 